\title{
International and Domestic Market Opportunities for Biomass Power Volumes I and II
}

Antares Group, Inc.

Landover, Maryland

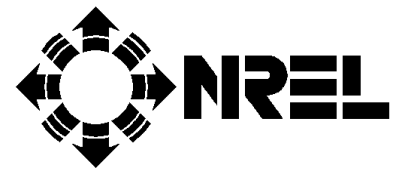

National Renewable Energy Laboratory 1617 Cole Boulevard Golden, Colorado 80401-3393

A national laboratory of the U.S. Department of Energy Operated by Midwest Research Institute for the U.S. Department of Energy under contract No. DE-AC36-83CH10093 


\section{International and Domestic Market Opportunities for Biomass Power}

\section{Volumes I and II}

Antares Group, Inc.

Landover, Maryland

Technical Monitor: Ralph Overend

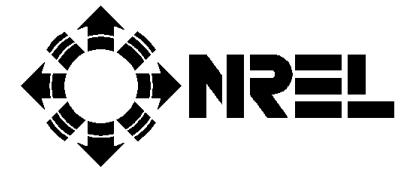

National Renewable Energy Laboratory 1617 Cole Boulevard

Golden, Colorado 80401-3393

A national laboratory of the U.S. Department of Energy Operated by Midwest Research Institute for the U.S. Department of Energy under contract No. DE-AC36-83CH10093

Prepared under Subcontract No. KAP-4-14083

September 1998 


\section{NOTICE}

This report was prepared as an account of work sponsored by an agency of the United States government. Neither the United States government nor any agency thereof, nor any of their employees, makes any warranty, express or implied, or assumes any legal liability or responsibility for the accuracy, completeness, or usefulness of any information, apparatus, product, or process disclosed, or represents that its use would not infringe privately owned rights. Reference herein to any specific commercial product, process, or service by trade name, trademark, manufacturer, or otherwise does not necessarily constitute or imply its endorsement, recommendation, or favoring by the United States government or any agency thereof. The views and opinions of authors expressed herein do not necessarily state or reflect those of the United States government or any agency thereof.

Available to DOE and DOE contractors from:

Office of Scientific and Technical Information (OSTI)

P.O. Box 62

Oak Ridge, TN 37831

Prices available by calling 423-576-8401

Available to the public from:

National Technical Information Service (NTIS)

U.S. Department of Commerce

5285 Port Royal Road

Springfield, VA 22161

(703) 487-4650 


\section{VOLUME I \\ Domestic Market Opportunities for Biomass Power}

TABLE OF CONTENTS

\section{FOREWORD}

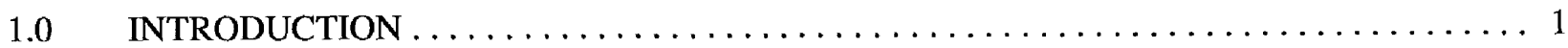

2.0 CURRENT STATE OF THE U.S. BIOMASS INDUSTRY $\ldots \ldots \ldots \ldots \ldots \ldots \ldots \ldots \ldots 2$

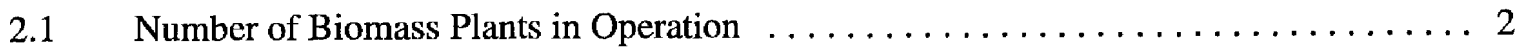

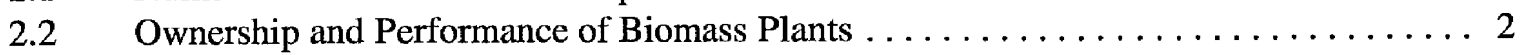

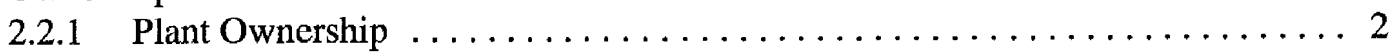

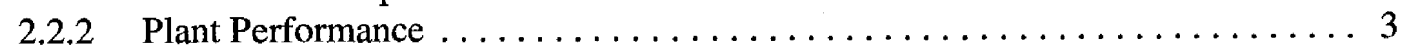

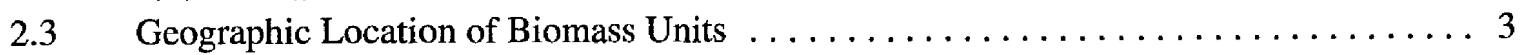

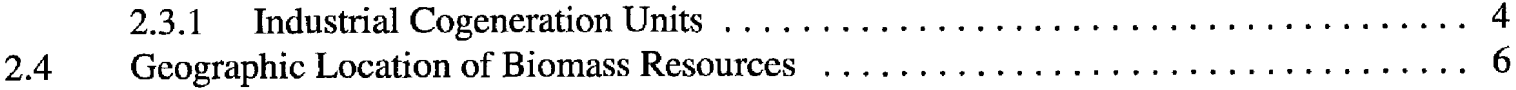

3.0 POLICIES AFFECTING BIOMASS DEVELOPMENT $\ldots \ldots \ldots \ldots \ldots \ldots \ldots \ldots \ldots \ldots \ldots$

3.1 Tax Incentives for Biomass Development $\ldots \ldots \ldots \ldots \ldots \ldots \ldots \ldots \ldots \ldots \ldots \ldots$

3.2 Tax Barriers to Biomass Development ......................... 9

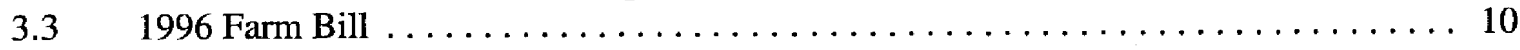

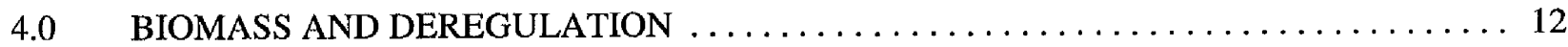

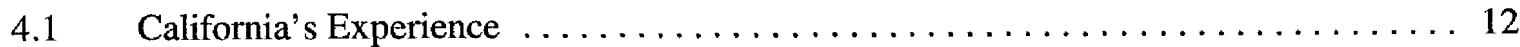

$4.2 \quad$ Renewables in a Competitive Market . . . . . . . . . . . . . . . 13

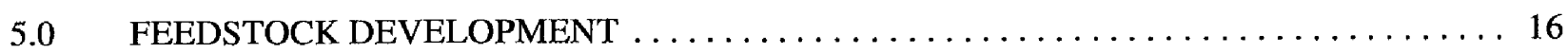

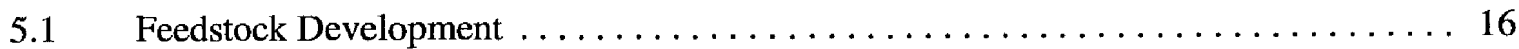

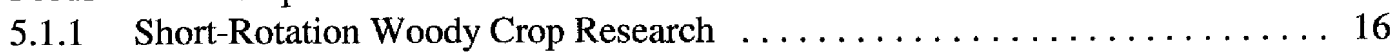

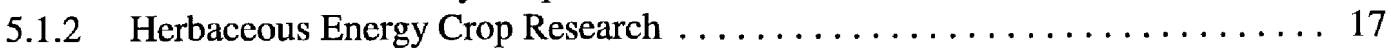

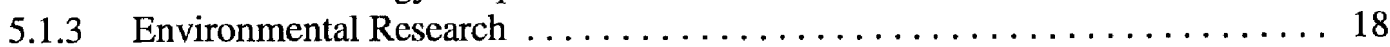

6.0 USDOE/USDA JOINT DEMONSTRATION PROJECTS $\ldots \ldots \ldots \ldots \ldots \ldots \ldots \ldots \ldots$

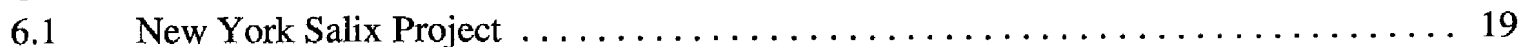

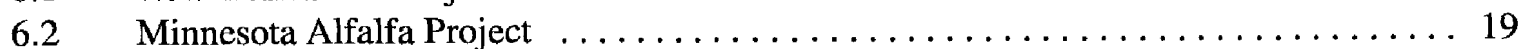

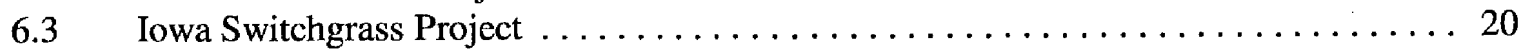

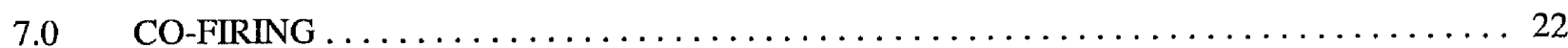

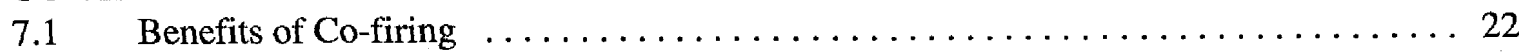

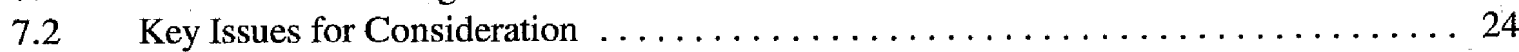

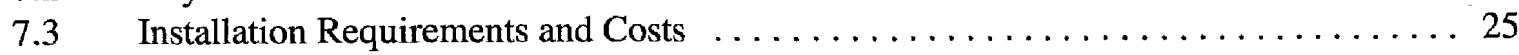

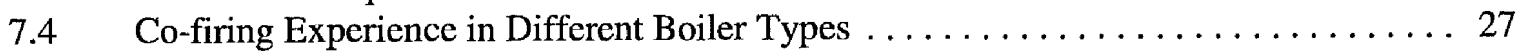

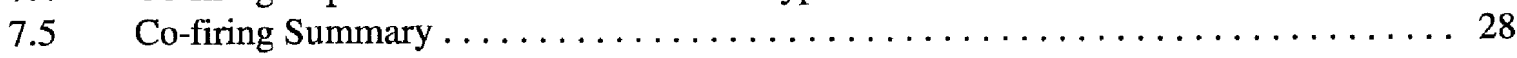

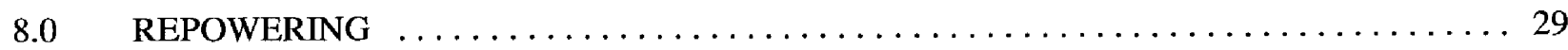

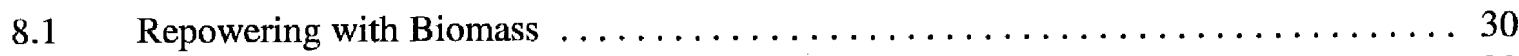

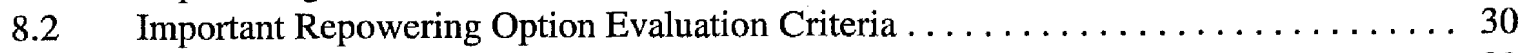

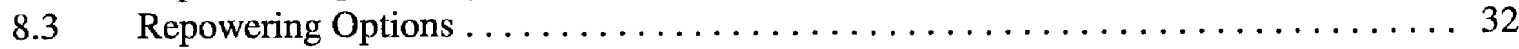

8.3.1 Substitute Combustion Turbine/Heat Recovery Steam Generator ......... 32 
8.3.2 Parallel Power Cycles: Feedwater Heater Repowering . . . . . . . . . 34

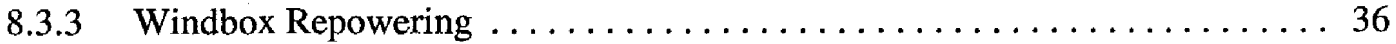

8.4 Gasification - Technology Review . . . . . . . . . . . . . . . . . . 37

8.4.1 Biomass Integrated Gasification Combined Cycles (BIGCCs) $\ldots \ldots \ldots \ldots . \ldots 38$

8.4.2 Black Liquor Gasification Combined Cycles ................. 39

$8.5 \quad$ Possible Opportunities to Use Biomass for Repowering $\ldots \ldots \ldots \ldots \ldots \ldots \ldots$

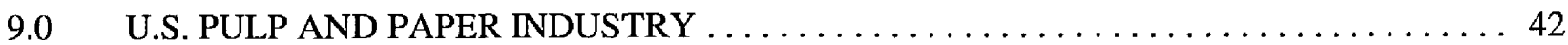

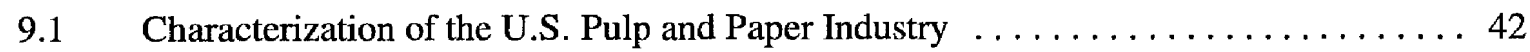

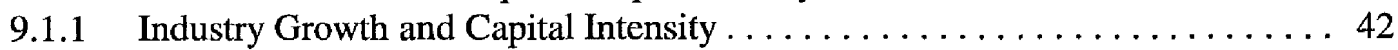

9.1.2 Demand for Electricity and Heat . . . . . . . . . . . . . . 43

9.1.3 The Importance of Biomass in the Pulp and Paper Industry . . . . . . . . 44

$9.2 \quad$ Pulp \& Paper Initiatives Toward Energy Self-Sufficiency $\ldots \ldots \ldots \ldots \ldots \ldots \ldots \ldots 4$

9.3 Black Liquor Gasification Combined Cycles (BLGCC) $\ldots \ldots \ldots \ldots \ldots \ldots \ldots$

9.3.1 The Kraft Chemical Pulping and Recovery Process $\ldots \ldots \ldots \ldots \ldots \ldots . \ldots 46$

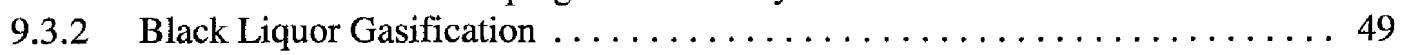

9.3.3 Cost Comparisons . .......................... 52

9.3.4 Effect of Gasification Technologies on the Pulp and Paper Operations . . . . 53

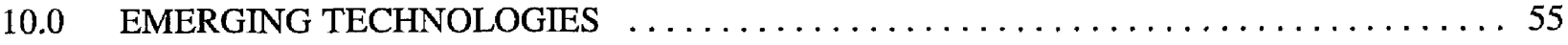

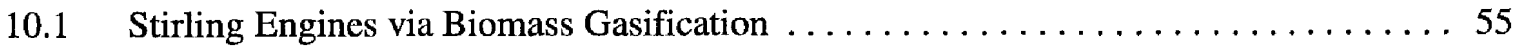

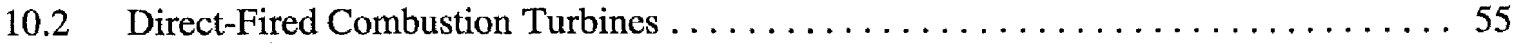

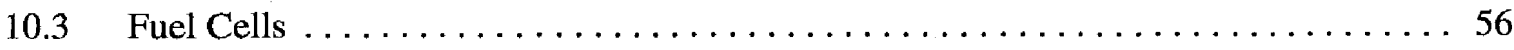

10.4 Biomass Integrated Gasification Combined Cycles (BIGCC) $\ldots \ldots \ldots \ldots \ldots \ldots$

$11.0 \quad$ KEYS TO SUCCESSFUL BIOMASS POWER PROJECTS $\ldots \ldots \ldots \ldots \ldots \ldots \ldots \ldots$

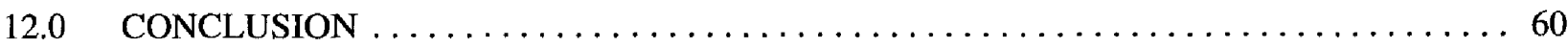




\section{EXHIBITS}

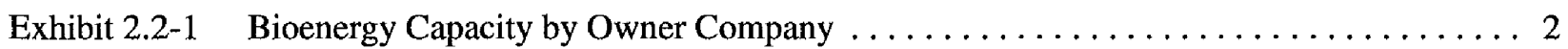

Exhibit 2.3-1 Bioenergy Capacity by FERC Region, in MW (includes 2,800 MW of MSW capacity) . 3

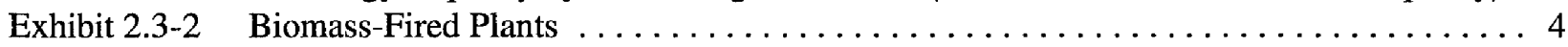

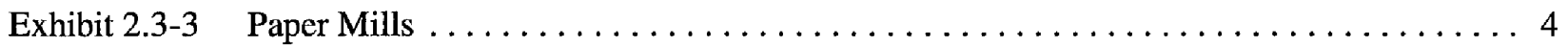

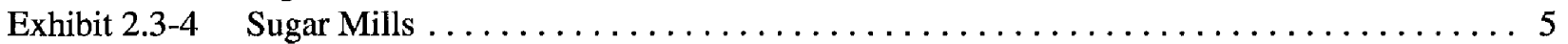

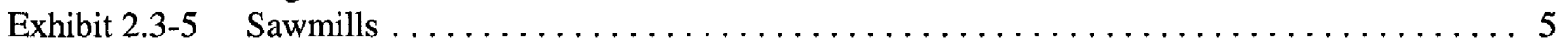

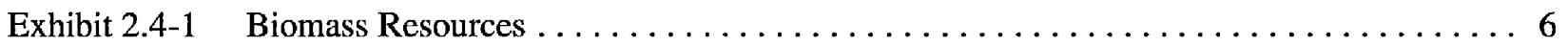

Exhibit $2.4-2 \quad$ Potential Energy Crop Resource Areas $\ldots \ldots \ldots \ldots \ldots \ldots \ldots \ldots \ldots \ldots \ldots$

Exhibit 3.1-1 Tax Incentives for Biomass Development $\ldots \ldots \ldots \ldots \ldots \ldots \ldots \ldots \ldots \ldots$

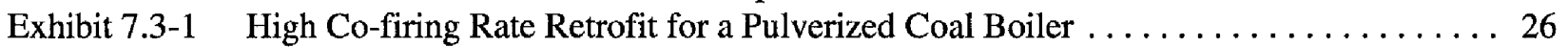

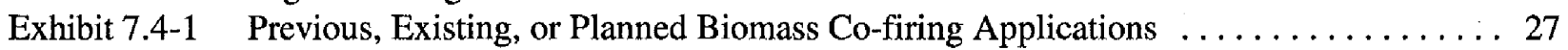

Exhibit 8.3-1 Substitute CT/HRSG Repowering $\ldots \ldots \ldots \ldots \ldots \ldots \ldots \ldots \ldots \ldots \ldots \ldots \ldots \ldots \ldots$

Exhibit 8.3-2 Substitute CT/HRSG Emissions Reductions NG Replacement Fuel . . . . . . . . . . 34

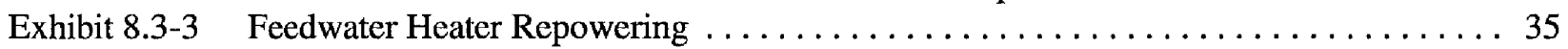

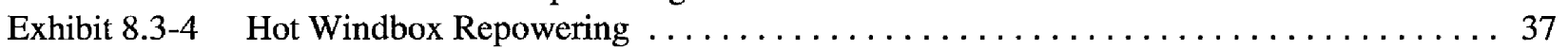

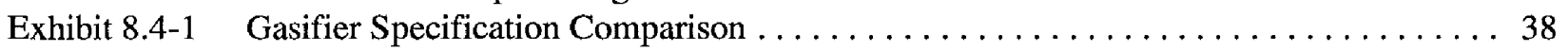

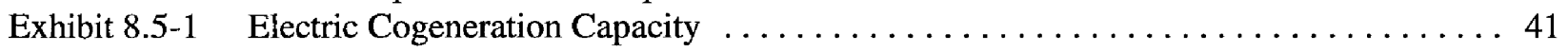

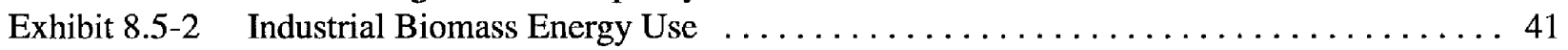

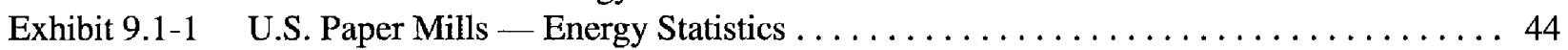

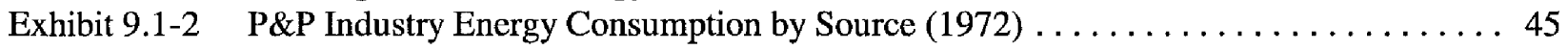

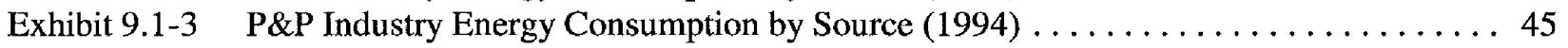

Exhibit 9.3-1 Kraft Chemical Recovery System $\ldots \ldots \ldots \ldots \ldots \ldots \ldots \ldots \ldots \ldots \ldots \ldots \ldots$

Exhibit 9.3-2 Conventional Pulp Mill Steam and Power Generation System Diagram . . . . . . . 48

Exhibit 9.3-3 Conventional Recovery Boiler System vs. Gasification-based Recovery System . . . . . 49

Exhibit 9.3-4 Kvaerner/CHEMREC High-Temperature, Air-Blown Gasification Combined-Cycle System Diagram . . . . . . . . . . . . . . . . . . . . . . . . . 51

Exhibit 9.3-5 Cost Comparisons for Conventional and Gasification-based Black Liquor Recovery

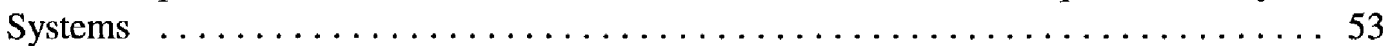

Exhibit $10.1-1$ STM Biomass Stirling Engine $\ldots \ldots \ldots \ldots \ldots \ldots \ldots \ldots \ldots \ldots \ldots \ldots \ldots \ldots \ldots$

Exhibit $10.1-2$ Sunpower Inc. Biomass Stirling Engine $\ldots \ldots \ldots \ldots \ldots \ldots \ldots \ldots \ldots \ldots \ldots \ldots$

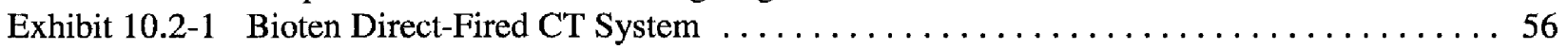

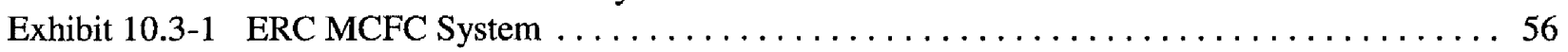

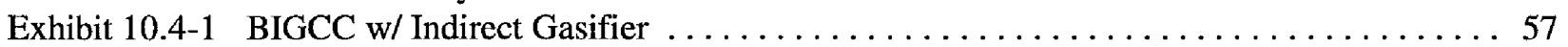




\section{FOREWORD}

As the 21st century nears, many of the world's economies are growing at a rapid pace and economic liberalization and market capitalism are taking hold. Commensurate with this growth is a rising demand for electricity. Conventional fuels hold a majority of the power generation market, a situation not expected to change in the future. However, environmental problems associated with fossil fuel combustion and a desire to diversify their fuel mix have led governments and electrical power providers to give more attention to renewable power generation options. One of these options is biomass. Biopower offers the simultaneous advantages of meeting electricity demand in an environmentally benign manner while potentially expanding agricultural employment and the rural economy.

Renewable power is of interest to many sectors including government, industry, environmental groups, and multilateral institutions. Each of these has a different agenda. Government and multilateral organizations, for example, are equally interested in the policy changes, institution-building, and sectoral reform needed to sustain the power market over the long term. Industry is primarily interested in the business opportunities presented by the domestic and international markets. While the public sector, large regulated utilities, and donor agencies have historically built most of the electric capacity worldwide, the private sector is increasing its presence in electrical power markets.

As competition increases and global demand for power accelerates, private power developers will become more influential and, in some electricity markets, indispensable players. Thus, this report is aimed at them. By involving themselves in the renewable power market, these developers are undertaking a dual responsibility-they must realize an adequate return on their investments while remaining mindful of a country's environmental and social objectives. Because of the comprehensive nature of this effort, the developer faces issues that are outside the realm of normal business practices, such as the public's view on the importance of a healthy environment relative to overarching economic and social concerns.

This report examines the domestic and international markets for biopower. Domestic and foreign markets present fundamentally different challenges to private power developers. The domestic market's operation is relatively transparent and well understood. Although power sector restructuring is proceeding and the outcome is uncertain, the domestic power sector is at least well-established and fiscally healthy. The principal task facing manufacturers and project developers is identifying those market niches where biomass-based electric systems are economically competitive. Although complicated by the current trend toward a deregulated electric power market, this task falls within the experience of market analysts and entrepreneurs.

Foreign electric power markets, like foreign markets generally, present additional problems to the project developer. Developing nations offer the greatest apparent opportunity due to the sheer magnitude of their electricity demand growth. However, international power markets and the foreign governments' policies toward their electric power sectors and outside investment can be vastly different from the experience in the U.S. Renewable power projects, because of their social and environmental element, add yet more complexity. This is further exacerbated when the power project is in a developing country.

Volume I of this report focuses on the domestic market for biopower. As noted, the U.S. power market is more readily understood than other markets. The domestic challenge lies in finding economically viable opportunities for biopower. Volume I outlines the current state of the U.S. biomass industry, discusses policies affecting biomass development, describes some demonstration projects currently underway, and discusses the future direction of the industry. It then explores the relationship between biopower and the 
impending restructuring of the electric power industry. The U.S. market assessment concludes with a discussion of various technological applications of biomass power.

Volume II of this report focuses on the international market for biopower. It first discusses world electricity demand and estimates future potential biopower capacity. Recent literature states that the investment and policy climate in foreign markets are the key elements in successful private project development. Thus, the remainder of the report discusses the financing issues, policy climate, and business incentives and barriers to biopower development. Since India and China are by far the biggest future markets for power, they are the focus of most of this report. After a discussion of potential biopower technology applications, this report briefly describes the climate for biopower in three other top markets, Brazil, Indonesia, and the Philippines. It concludes with a list of potential financing sources to provide the developer with a starting point for seeking financial assistance. 


\subsection{INTRODUCTION}

Fluctuations in fossil fuel prices and increasingly stringent environmental controls continue to provide opportunities for the growth of the U.S. biomass power industry. The rapidly changing nature of the U.S. electric industry offers opportunities for nonconventional power sources to enter the field. ${ }^{1}$ Biomassgenerated power grew from less than 200 MegaWatts (MW) in 1979 to more than 7,000 MW by the mid$1990 \mathrm{~s}^{2}$ It represents one option that can meet two objectives that often conflict: environmental protection and economic development.

The intent of this report is to highlight the domestic market opportunities for biomass power. The report begins with a brief overview of the current state of the U.S. biomass power industry and then discusses how tax policies and the 1996 Farm Bill influence its development. The next section describes a few of the promising demonstration biomass power projects and continues with an overview of the largest group of biopower generators, the pulp and paper industry. The report then discusses future opportunities for the biomass industry, specifically in the areas of feedstock development, co-firing, and repowering. Note that Municipal Solid Waste (MSW) is not treated in the course of this report. It concludes with a discussion of deregulation and its effect on biomass power and renewables in general.

1 DOE, 1992, Electricity from Biomass: A Development Strategy, p. 5.

2 DOE, 1996, DOE Biomass Power Program: Strategic Plan 1996-2015, p. 7. 


\subsection{CURRENT STATE OF THE U.S. BIOMASS INDUSTRY}

\subsection{Number of Biomass Plants in Operation}

There are more than $7,000 \mathrm{MW}$ of biomass power capacity installed in the U.S. ${ }^{3}$ This power is produced by more than 350 plants ranging from pulp and paper mills, electric utilities, and independent power producers (IPPs). Because such a variety of plants use biomass to generate power, it is difficult to get an accurate count of the number of biomass units in the U.S. In addition, a large portion of the generators are not regulated utilities, so data collection is further hampered. This is important to keep in mind, as these numbers probably under-estimate the actual count of biomass units and total capacity.

\subsection{Ownership and Performance of Biomass Plants}

\subsubsection{Plant Ownership}

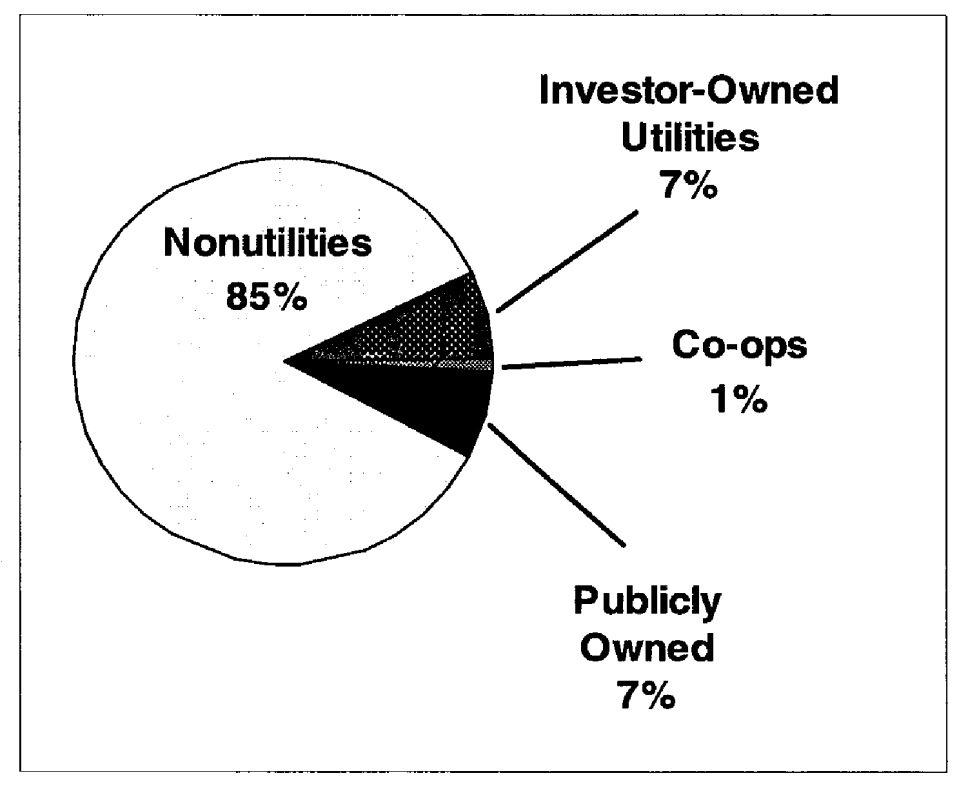

EXHIBIT 2.2-1

Bioenergy Capacity by Owner Company

The more than 7 GigaWatts (GW) of

domestic biomass-generated electricity represents approximately one percent of all generating capacity and 8 percent of non-utility generation capability. ${ }^{4}$ Of this capacity, 80 percent is from cogeneration in the primary and secondary forest products industries. Dedicated stand-alone electric power generation makes up the next largest sector of biomass power. These facilities are typically fueled with non-captive residues drawn from urban activities and from smaller or seasonal sources such as orchards, food processing, and building construction and demolition.

Ownership of the biomass power plants can be broken into four major categories with non-utility producers the largest sector. Of the estimated seven gigawatts of biomass- generated electricity, 85 percent is from non-utilities (including independent power producers), 7 percent is from investor-owned utilities, 7 percent is from publicly owned utilities, and 1 percent is from rural electric cooperatives. ${ }^{5}$ The non-utility producers include industrial generators such as pulp and paper manufacturers. Section 3.3 of this report focuses on this industry.

\footnotetext{
${ }^{3}$ This excludes plants fueled by municipal solid waste.

${ }^{4}$ DOE, DOE Biomass Power Program Strategic Plan 1996-2015, p. 3.

${ }^{5}$ Op. cit.
} 


\subsubsection{Plant Performance}

For stand-alone facilities that produce only electricity, net power efficiency in the existing biomass power industry is in the 20 to 25 percent range. While this efficiency is lower than modern coal- and gas-fired steam units, recent projects have demonstrated the ability to achieve improved reliability and efficiency. The biomass industry set an efficiency goal of 40 percent for an Integrated Gasification Combined-cycle (IGCC) plant. ${ }^{6}$

\subsection{Geographic Location of Biomass Units}

The U.S. biomass power industry is located primarily in the Northeast, Southeast, and along the West Coast, representing an investment of $\$ 15$ billion and supporting about 66,000 jobs. ${ }^{7}$ Today's biomass power plants use direct combustion Rankine cycle technology in industrial facilities, which is the same technology used by many fossil-fired plants, most notably coal plants. Exhibit 2.3-1 shows the bioenergy capacity by Federal Energy Regulatory Commission region. ${ }^{8}$ Excluding MSW, ninety percent of the residues used for biomass power production are wood waste and the remainder are agricultural residues. ${ }^{9}$ Biomass fuels include chipped logs and forest residue, agricultural residues, and residues from manufacturing and milling processes.

Power producing utilities have looked to the wood and paper products industry for ideas on burning biomass. The wood and paper products industry is the leader in burning biomass for both thermal and electric power. With a base of more than 500 mills, the American pulp and paper industry is the largest

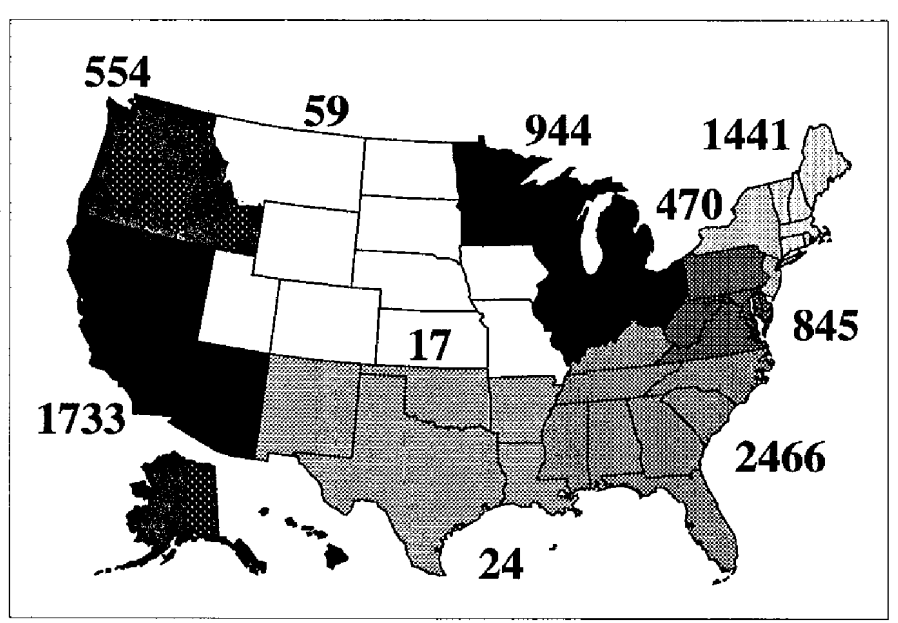

EXHIBIT 2.3-1

Bioenergy Capacity by FERC Region, in MW (includes 2,800 MW of MSW capacity) such sector in the world. In 1994, 14 percent of the pulp and paper industry's fuel requirements were met by hogged wood fuels and bark. ${ }^{10}$

For some power producing facilities, cofiring biomass may be the most viable near-term and cost-effective option. The Clean Air Act Amendment imposed new $\mathrm{SO}_{2}$ restrictions on allowable emissions from U.S. coal-fired power generating stations. To comply, utilities have implemented a variety of strategies including: using low sulfur coal, installing scrubbers (flue gas desulfurization systems), cleaning the coal,

${ }^{6}$ DOE, 1996, Biomass Power Program Review, presentation, December 9.

${ }^{7}$ DOE, DOE Biomass Power Program Strategic Plan 1996-2015, p. 3.

8 DOE/EIA, 1995, Renewable Energy Annual 1995, p. 138.

9 DOE, 1996, DOE Biomass Power Program Strategic Plan 1996-2015, p .3.

${ }^{10}$ Miller Freeman, 1996, Pulp \& Paper 1997 North American Factbook. 
purchasing $\mathrm{SO}_{2}$

allowances, and

burning/cofiring biomass.

Exhibit 2.3-2 shows the regional breakdown of the country's biomass units.

The dots represent a range of producers including the pulp and paper industry, electric utilities, and independent power producers.

Source: Rueckert and Easterly, eds., 1995, "DOE Biomass Power

Program Update," Biologue, 2nd quarter

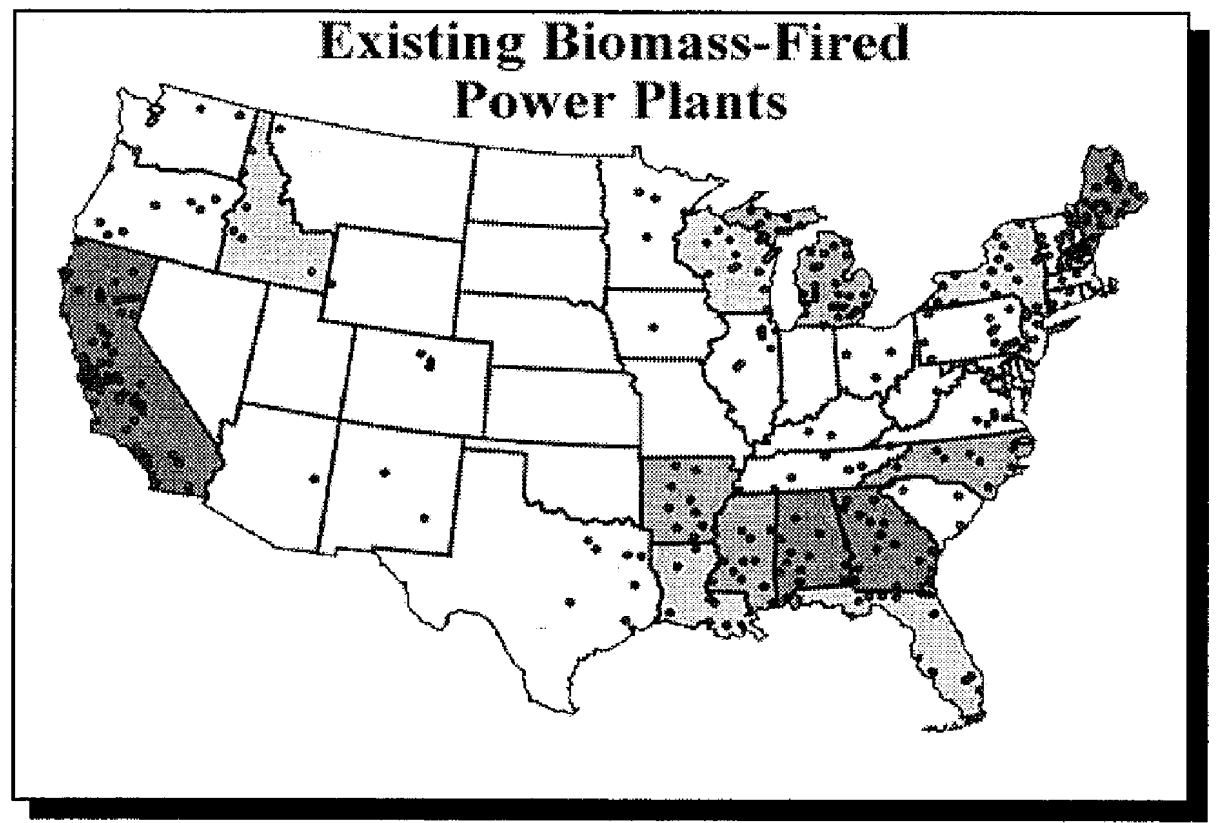

EXHIBIT 2.3-2

Biomass-Fired Plants

\subsubsection{Industrial Cogeneration Units}

Utility Data Institute's (UDI) database of U.S. Cogeneration, Small Power and Industrial Power Plants contains information for more than 4,000 active projects including a breakdown of industrial cogeneration plants by Standard Industrial Classification (SIC) code. Power generation information is provided for 192 operating paper mills (SIC 262), the largest group of biopower generators. The database also provides similar information for operating sawmills (SIC 242) and sugar mills (SIC 206). UDI did not use one standard method or resource to obtain these data, so the lists are incomplete. However, at the time of this report, it was the most comprehensive data source available. Exhibits 2.3-3 through 2.3-5 show the location and number of mills, by state, based on UDI data. States that are not shaded do not contain any of the three mill types, according to UDI.

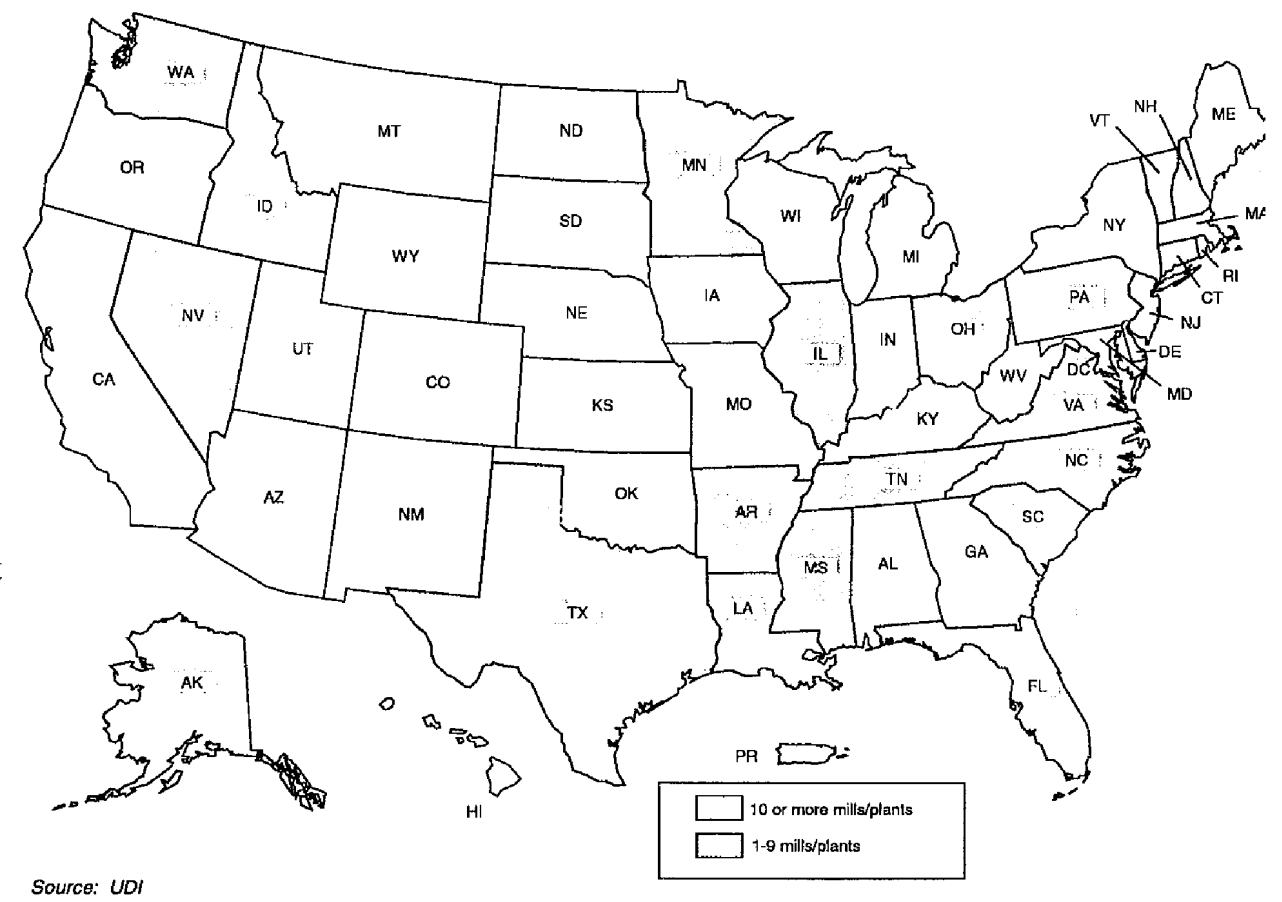

EXHIBIT 2.3-3

Paper Mills 


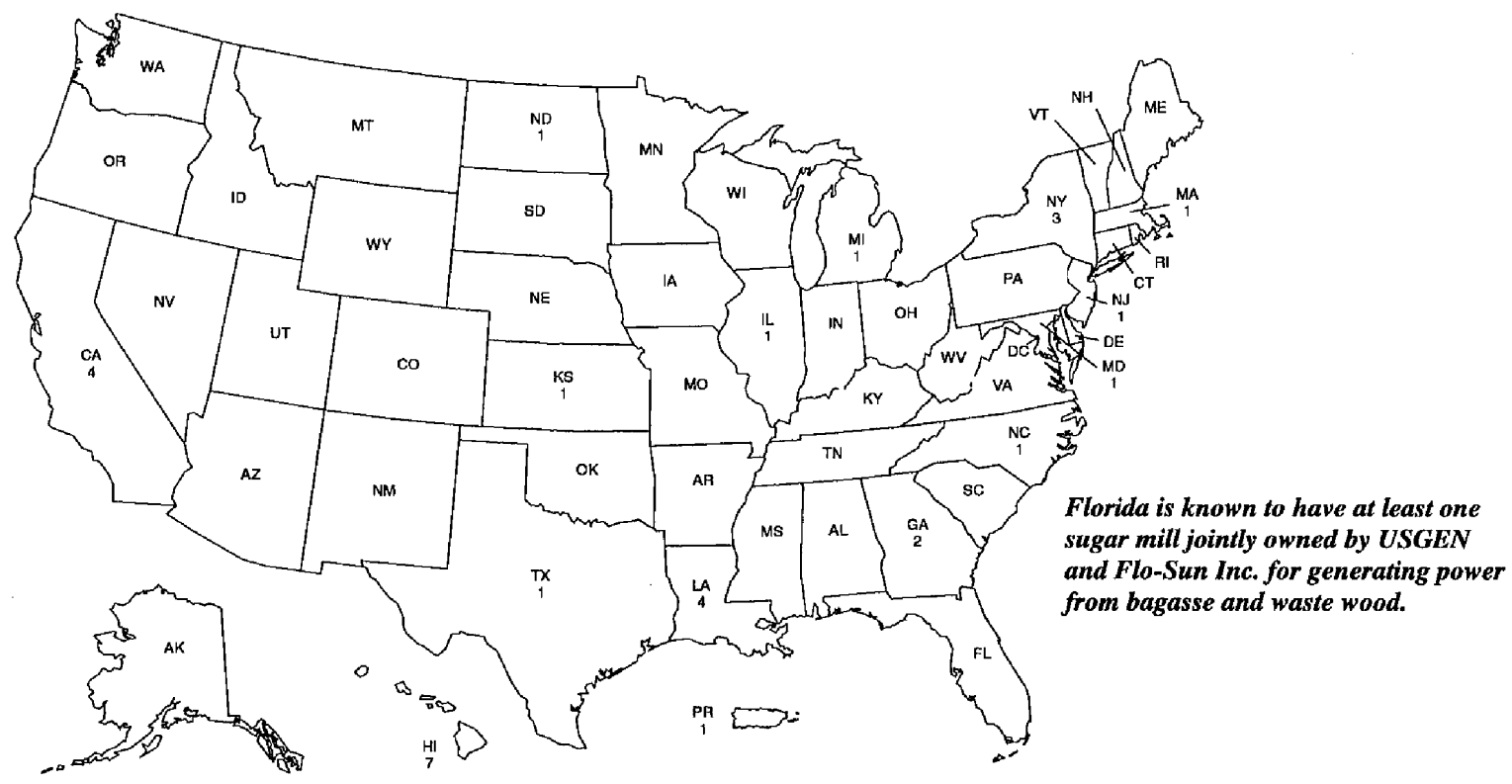

Sourco: UDI

EXHIBIT 2.3-4

Sugar Mills

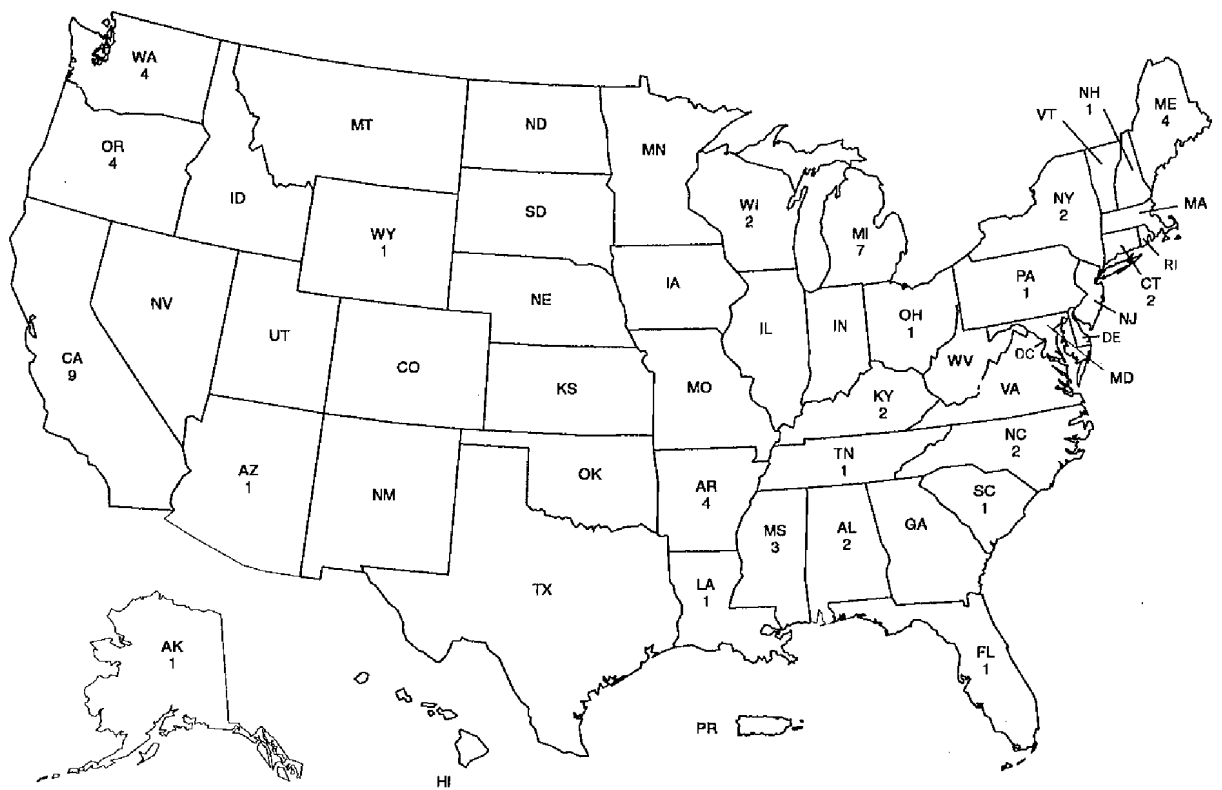

Source: UDI

EXHIBIT 2.3-5

Sawmills

\# of mills in each state for Exhibits 2.3-4 and 2.3-5 is shown below state abbreviation 


\subsection{Geographic Location of Biomass Resources}

Conventional biomass power generation units predominantly use forestry and agricultural residues as their fuel. In the future, provided they are economically viable, advanced biopower technologies will probably also rely on energy crops to provide a steady fuel supply. Exhibits 2.4-1 and 2.4-2 highlight the geographic areas best suited for biomass power units, based on current availability of residues and in the longer term, energy crop fuel supplies.

\section{Agricultural Residues and Forest Resources}

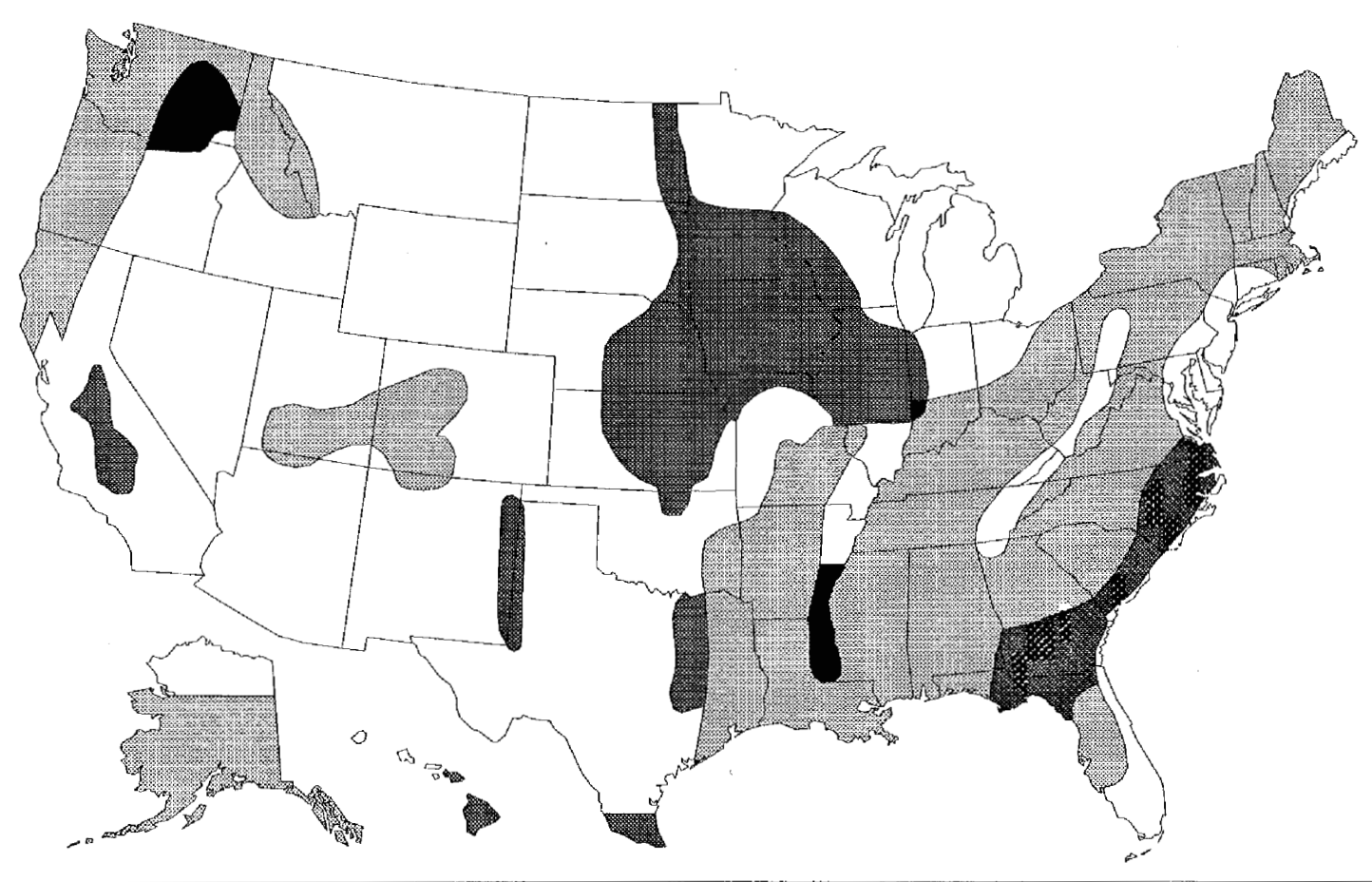

Agricultural Residues

Agricultural and Wood Residues

Low Inventory

Wood Resources and Residues

Wood Resources and Agricultural and Wood Residues

Source: U.S. Department of Energy, Renewable Energy Technology Evolution Rationales, SERI/TP-260-4427; DE $91015 a 16$ October 1990.

EXHIBIT 2.4-1

Biomass Resources 


\section{Energy Crop Resources}

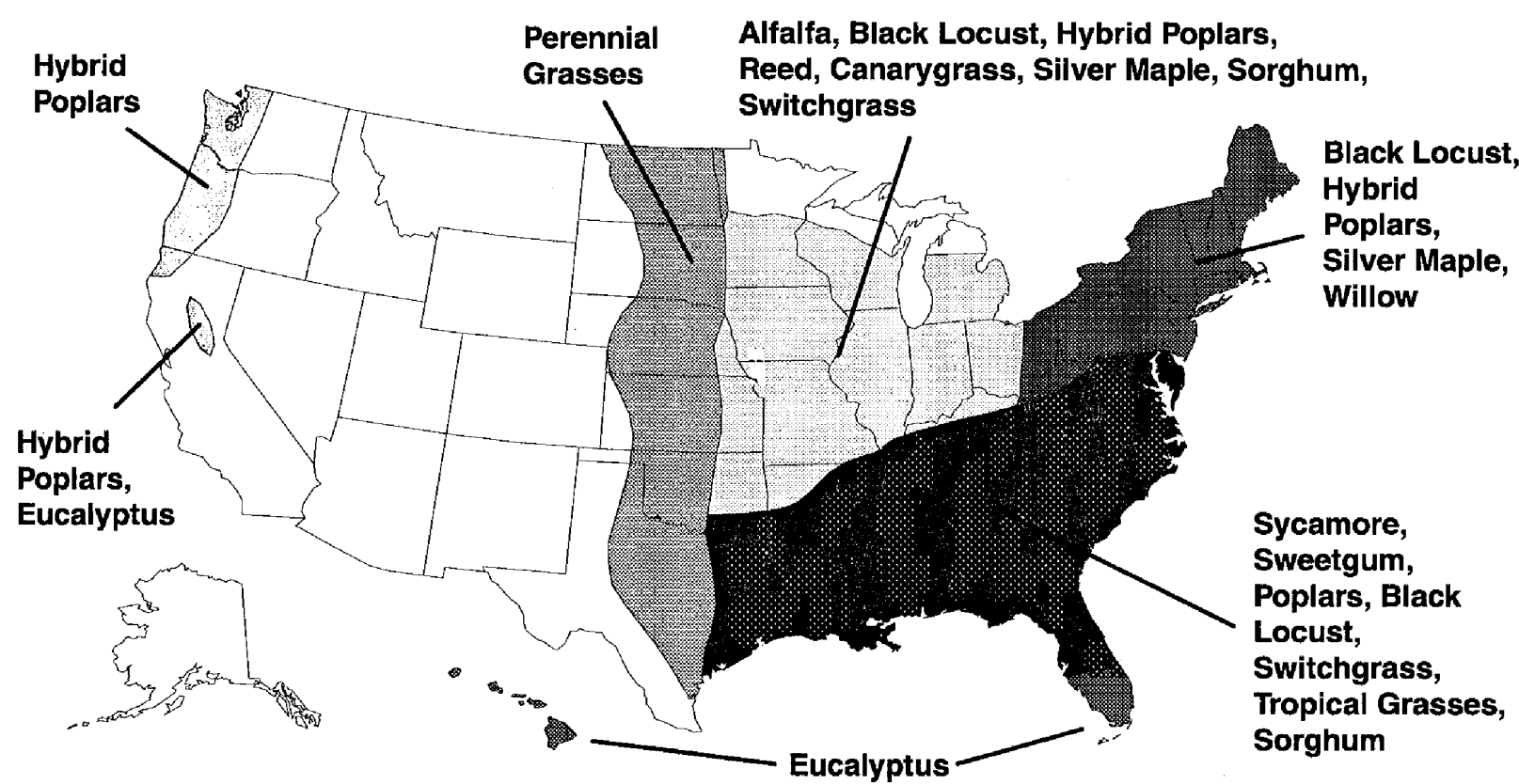

Source: Turnbull, Jane, Strategies for Achieving a Sustainable, Clean and Cost-Effective Biomass Resource, EPRI, Proceedings: Strategic Benefits of Biomass and Waste Fuels, December 1993, p 2-59.

EXHIBIT 2.4-2

Potential Energy Crop Resource Areas

In order for biomass power units to provide competitively priced electricity, the fuel supply must be in close proximity. Some experts have established a maximum fuel supply radius of 75 miles (if transported by road). ${ }^{11}$ Similar information was not available for waterway or railway transportation. As shown in Exhibit 2.4-1\&2, biomass resources are concentrated in the eastern, east-central, and western regions of the country. Not surprisingly, the units depicted in Exhibits 2.3-2 through 2.3-5 are located in the same general areas. Long-term prospects also seem promising. The expansion of the U.S. biomass power market will hinge on the ability of generating companies to obtain fuel inexpensively and in steady supply. The location of plants relative to this supply is therefore of prime importance.

\footnotetext{
${ }^{11}$ Turnbull, Jane, EPRI, 1993, Strategies for Achieving a Sustainable, Clean and Cost-Effective Biomass Resource, p. 5.
} 


\subsection{POLICIES AFFECTING BIOMASS DEVELOPMENT}

There are various economic and regulatory factors affecting biomass development. This section focuses on how tax issues and the 1996 Farm Bill affect the implementation of biomass technology.

\subsection{Tax Incentives for Biomass Development}

Compared to conventional fuel technology, biomass technology is still in its early stages. In order to stimulate its development, the U.S. Government provided tax incentives for various biomass projects. Exhibit 3.1-1 provides a brief description of each incentive.

EXHIBIT 3.1-1

Tax Incentives for Biomass Development

Tax Incentive

Renewable Energy
Production Tax Credit
(REPC)

Renewable Energy

Production Incentive (REPI)

Section 29 Biomass Gas Credit

Alcohol Fuels Credit

\section{General Description}

*

$*$

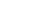

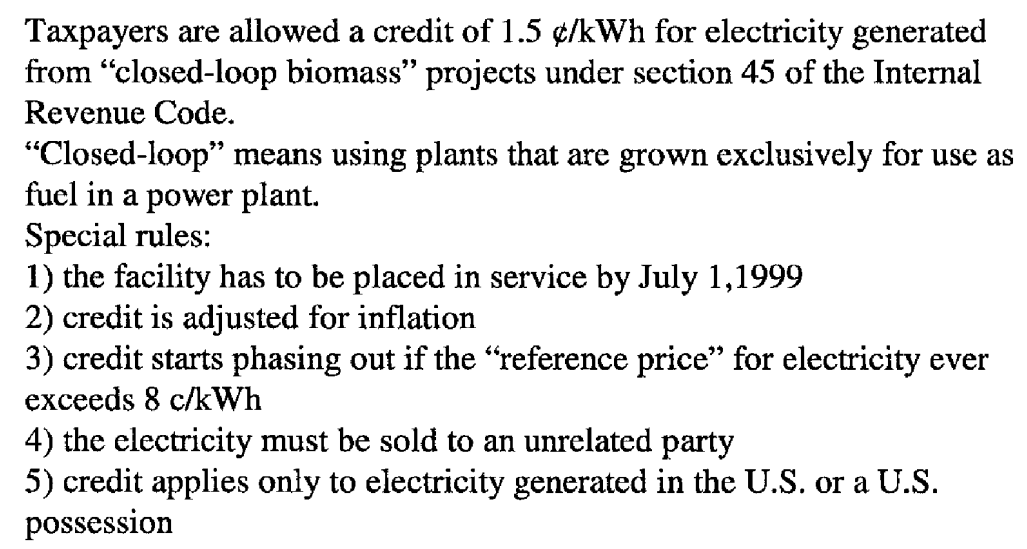
from "closed-loop biomass" projects under section 45 of the Internal Revenue Code. "Closed-loop" means using plants that are grown exclusively for use as fuel in a power plant.

Special rules:

1) the facility has to be placed in service by July 1,1999

2) credit is adjusted for inflation

3) credit starts phasing out if the "reference price" for electricity ever exceeds $8 \mathrm{c} / \mathrm{kWh}$

4) the electricity must be sold to an unrelated party

5) credit applies only to electricity generated in the U.S. or a U.S. possession

Section 1212 of the 1992 Energy Policy Act allows the USDOE to make payments of $1.5 \phi / \mathrm{kWh}$, adjusted annually for inflation, for electricity generated and sold by qualifying facilities.

For this incentive, a qualifying facility is one that is publicly owned (e.g., a state-owned facility) or owned by a non-profit electrical cooperative.

"Closed-loop biomass," wind, solar, and geothermal projects are eligible. REPI funding is appropriated by Congress annually; no funds have yet to been disbursed.

Section 29 of the Internal Revenue Code contains a credit for the production and sale of gases derived from biomass. With respect to biomass facilities, this credit applies to methane recovered from landfills, methane from anaerobic digestion of livestock manures and municipal wastes, and gases derived from thermal gasification of wood and crop residues.

* The amount of credit for 1995 was $\$ 5.83$ per each 5.8 MMBtus produced and sold.

* The credit is adjusted annually for inflation

* $\quad$ Facility has to be placed in service by June 30, 1998.

* Taxpayers can benefit from a tax credit of up to 60 cents/gallon by converting biomass into ethanol or methanol. 
Accelerated Depreciation $\quad * \quad$ Certain equipment in an electric generating plant that uses biomass for fuel qualifies for depreciation over 5 years using the $200 \%$ decliningbalance method, provided the plant is a "qualifying facility" (QF) as defined in Public Utility Regulatory Policy Act (PURPA). As outlined in PURPA, utilities have to purchase electricity from a $Q F$, which is a nonutility generator of less than $80 \mathrm{MW}$ that either uses renewable fuel or is a cogenerator, provided it is priced at the utility's avoided cost.

* The following equipment qualifies:

1) boilers

2) burners

3) pollution control equipment required by law

4) equipment for the "unloading, transfer, storage, reclaiming from storage and preparation" at the place where biomass will be used as fuel

Tax-Exempt Financing $\quad * \quad$ Assuming that the facility has more than $10 \%$ private business use, biomass projects can qualify for tax-exempt financing if they fit into one of these two categories:

1) Two-county rule: if the project supplies gas or electricity to an area no larger than two contiguous counties or one city and a contiguous county 2) If the facility is a solid waste disposal facility

* An example of private business use is where a garbage-burning power plant is owned by a local government, but it is leased to a private company.

* If tax-exempt financing is used, accelerated depreciation and certain tax credits, such as the unconventional fuels and production tax credits, must be forfeited.

Source: Martin, Keith, 1995, "Tax Issues and Incentives for Biomass Projects," in Proceedings of the Second Biomass Conference of the Americas, August 21-24, pp.1363-1371.

Of these incentives, biomass-fueled power is mainly affected by the $1.5 \phi / \mathrm{kWh}$ REPC and accelerated depreciation. As explained in section 3.2, on a pure cost-of-electricity basis, a biomass power plant using dedicated feedstocks will probably not be competitive with conventional fuels unless it can take advantage of these tax benefits.

\subsection{Tax Barriers to Biomass Development}

Several studies have looked at tax loads associated with conventional versus renewable fuel power generating technologies. ${ }^{12}$ They asked if current tax policy was an incentive or barrier to adopting renewable energy technologies. These studies concluded that renewable power projects carry higher tax burdens under current tax codes. This is because technologies with dissimilar capital/labor/fuel ratios are used to provide the same service, electricity, but each input is taxed differently. As a result, technologies that are more capital-intensive, such as renewables, tend to pay more in Federal, state, and local taxes than do the conventional technologies such as natural gas and coal.

\footnotetext{
12 Jenkins, Alec, et al., 1996, “Tax Barriers to Biomass and Other Renewable Generation Technologies,” footnote 4.
} 
One study looked at the full fuel cycle of utility-generated power for two conventional and four renewable power generating technologies. ${ }^{13}$ Six greenfield sites were modeled in each of the two reference environments, California and Massachusetts. Although the data were obtained from actual power utilities, the scenarios were built as hypothetical case studies. The study assessed the Federal, state, and local tax burden at each stage of the power generation process: fuel extraction, fuel transportation, and power generation. Transmission and distribution costs were not included in the analysis.

The authors found that capital and construction are taxed more heavily than operation and maintenance. As a result, at the busbar, the natural gas fuel cycle received the most favorable overall tax treatment compared to the coal, wind, hydro, solar thermal, and biomass technologies. This was due to the high proportion of fuel in its total input mix, which was its least-taxed component. The capital-intensity and associated tax burden of the hydro, wind, and solar thermal technologies overshadowed the absence of fuel costs in their total input mix. The REPC may have been envisioned by policy makers as a means partially to address the advantages conventional power generation technologies enjoy over renewables.

For the biomass case study, the authors conducted a sensitivity analysis on the effect of the $1.5 \mathrm{c} / \mathrm{kWh}$ REPC on its overall cost of electricity. These biomass power plants were assumed to be "closed-loop," using dedicated feedstocks for their fuel supply. As described in Exhibit 3.1-1, only closed-loop biomass projects can take advantage of the REPC. Results of the sensitivity analysis showed that, with the benefit of accelerated depreciation but without the REPC, biomass power plants were not competitive on a levelized cost of electricity basis when compared to plants powered by conventional fuels. When the REPC was added in, results were more favorable, but the biomass plants still could not compete with natural gas. Currently, there are no commercial biomass plants in the U.S. using dedicated energy crops, so this credit has not been a factor in biomass power generation.

As indicated by the various studies, tax incentives for renewables are a necessary ingredient in today's power generation climate. Even with currently available tax credits, biomass and other renewables at a utility power production scale cannot compete with conventional fuels (especially natural gas) on a pure cost of production basis. Moreover, particularly in the current political climate, it is unlikely that they can be counted on as a permanent solution. However, in the short term, renewables need preferential policy treatment and $R \& D$ support to bring their production costs down to a more competitive level. This will be especially important in an era of deregulation, where rates of return will not be guaranteed and decisions will largely be made on production costs.

\subsection{Farm Bill}

The U.S. Congress passed the Federal Agricultural Improvement and Reform (FAIR) Act in April 1996, but its impact on the future of bioenergy is uncertain. FAIR allows participating producers to receive government payments independent of farm prices. In the past, deficiency payments were dependent on farm prices. However, this legislation does not include language specifically authorizing the harvesting of energy crops from Conservation Reserve Program (CRP) lands. ${ }^{14}$ The following is a list of potential opportunities for bioenergy offered by the new Farm Bill: ${ }^{15}$

\footnotetext{
${ }^{13}$ Burtraw, Dallas and Pallavi Shah, 1995, Fiscal Effects of Electricity Generation Technology Choice: A Full Fuel Cycle Analysis.

${ }^{14}$ Rinebolt, David, 1996, “The Farm Bill: A Mixed Bag for Biomass,” p. 10.

${ }^{15}$ Ibid., p. 11.
} 
- The elimination of payments tied to specific commodities makes a large percentage of cropland available for energy crop production. Farmers will continue to receive subsidy payments on the land for seven years, regardless of what is planted.

- The Forestry Incentive Program, which promotes sustainable forestry practices, is reauthorized through 2002. It will continue to provide technical assistance and some payments (depending on appropriations levels) for producers wishing to create new timber stands or improve existing wood lots.

- Most of the environmental programs which provide technical assistance and cost-sharing for environmental management activities, which can include energy crop production, are continued through 2002.

- The Conservation Reserve Program is extended for an additional seven years, with farmers given the option to break contracts after five years. This could help in the development of biomass plantations.

- The Secretary of Agriculture is encouraged to consider biomass production as an acceptable cover crop practice (cover crops are used for soil enhancement or soil conservation applications).

- A U.S. Treasury account was established to provide funds for rural development programs and a competitive grant program to support research, education, and extension activities. One of the objectives of the Fund for Rural America is to "develop new uses and new products for agricultural commodities, such as alternative fuels, and develop new crops."16

Through this Act, farmers will have greater flexibility to make planting decisions and they will rely more heavily on the market as a guide. Energy crop production will most probably have greater opportunities with this legislation, but the biomass industry will have to work with farmers in order to realize any longterm success.

\footnotetext{
${ }^{16}$ U.S. Department of Agriculture, 1997, "Fund for Rural America: Guidelines for Proposal Preparation and Submission for Fiscal Year 1997," p. 1.
} 


\subsection{BIOMASS AND DEREGULATION}

After many years of a relatively quiet existence, the U.S. electric industry is undergoing a transformation. The forces of competition are for the first time shaping an historically regulated industry. On a national scale, it is unclear whether deregulation will create more or fewer opportunities for non-utility generators (NUGs) and cogenerators. On the one hand, competition usually leads to an easier market entry, so these non-utilities may have a greater chance of tapping into the power market. However, impending deregulation is intended to lead to lower prices, so existing utilities will be forced to reassess their markets and mode of operation to remain competitive. Utilities will become leaner and more aggressive, making for tough competition through revitalized generation strategies.

The impending electric industry deregulation has led to much speculation about its effect on renewable energy technologies. It is commonly understood that until they can compete on a cost-of-electricity basis, regardless of the ultimate restructuring approach, deregulation will require that renewables receive additional assistance to become a more significant part of the U.S. power generation mix. In the absence of a national restructuring plan, states are already introducing proposals aimed at supporting renewables. From their efforts, it is apparent that in the short term, renewables will need assistance such as tax credits and legislation focused on strengthening their position in the nation's electricity mix.

\subsection{California's Experience}

California's situation provides a window on the issues facing those involved in the biomass power industry in the face of deregulation. The state led the world in the development of renewable energy, and specifically biomass power. Between 1990 and 1993, the state's biomass operating capacity grew at an annual rate of 1.3 percent, resulting in $838 \mathrm{MW}$ by the end of $1993 .{ }^{17}$ However, in 1994, with approval from the state public utility commission, utility companies began making buy-out offers for standard power purchase agreements that were a major factor in the industry's development. By the second quarter of 1995 , more than $250 \mathrm{MW}$ of capacity accepted buy-outs and shut down operations. ${ }^{18}$ This volatility forced the state to address additional forces acting on the industry. As a result, California was the first state in the country to approach the deregulation issue.

Retail wheeling: customers allowed to purchase electricity directly from competing suppliers

Wholesale wheeling: electric utilities allowed to set up buying pools and purchase lowest-cost power available to them
In 1994, the California Public Utility Commission (CPUC) announced that it intended to restructure the state's electric utility industry. Its "retail wheeling" proposal would end the monopoly status of regulated utilities by allowing customers to purchase electricity directly from competing suppliers. This original proposal, however, stated that cost would be the sole factor determining which generating sources would be utilized in

the state. This would have created a disadvantage for all the new generating technologies (including nonhydro renewables) that had not been on the market long enough to reduce their cost of production to a competitive level. The California PUC withdrew the original proposal and replaced it with one that focused on the concept of "wholesale wheeling." Wholesale wheeling offers a more manageable rate of

\footnotetext{
${ }^{17}$ Morris, G., 1995, "The California Biomass Power Industry in the Era of Restructuring," p. 1383.

${ }^{18}$ Op. cit.
} 
change by allowing electric utilities to set up buying pools and purchase the lowest-cost power available to them, rather than relying completely on self-generation. In this way, the utilities are both power brokers and distributors.

To help sustain the market for renewables within a deregulated industry, the CPUC sanctioned a working group that included representatives from renewable energy industries, major investor-owned and municipal utilities, and environmental and consumer advocate groups. The goal of this Renewables Working Group was to report to the CPUC on the implementation of a renewables program for the state. It took three approaches: ${ }^{19}$

- the establishment and enforcement of a renewable portfolio standard (RPS) mandating a minimum level or percentage of energy in the state be produced from renewable sources (The California legislature recently eliminated this approach.)

- the establishment of a fund for renewables, collected via a surcharge on electricity bills, and distributed via an auction to renewable power generators as production credits (e.g., a System Benefit Charge (SBC))

- foster renewables production voluntarily using green marketing techniques, in effect encouraging electric service providers in a competitive market to offer customers a "green" portfolio of services

In response to the RPS suspension, the California Energy Commission (CEC) sponsored bill A.B. 1890 which establishes a four-year, $\$ 540$ million fund to support existing, new, and emerging renewable electricity-generating technologies. Biomass is scheduled to receive the largest share of funding directed towards renewable energy technologies.

\subsection{Renewables in a Competitive Market}

Despite its failure to get approval in California, the RPS is one of the more promising mechanisms designed to support renewables within a restructured environment. The SBC is another approach. The SBC is a non-bypassable charge to distribution customers to fund public benefit programs, including energy efficiency and renewable energy programs. ${ }^{20}$ The primary advantage of this system is that the charge to customers is known and fixed. An example is an Auctioned Renewables Credit which allows developers to submit bids to utilize SBC funds; the funds could then be awarded to those proposals that can deliver the most renewable power at the least cost. ${ }^{21}$

Representative Schaefer (R-CO) was the first to introduce a bill protecting renewables in a restructured environment. His bill proposed that all generators of electricity selling power would be required to have renewable energy credits ${ }^{22}$ equal to 2 percent of their generation (increasing to 4 percent by the year 2010). Currently, this bill is being reintroduced in the 105th Congress. Renewables were also given special notice in a recently proposed deregulation bill introduced by Senator Dale Bumpers (D-AR). His bill would

\footnotetext{
${ }^{19}$ Morris, Gregory, 1995, "The California Biomass Power Industry in the Era of Restructuring," pp. 1387-1388.

${ }^{20}$ Nogee, Alan, 1996, Renewable Energy and Electric Utility Restructuring in the Mid-Atlantic Region: Risks and Opportunities, p. 19.

${ }^{21}$ Op. cit.

${ }^{22}$ Credits may be obtained by directly investing in renewable generation or by purchasing renewable energy credits on the open market.
} 
require companies selling power at retail to generate 5 percent of their electricity from renewable resources. ${ }^{23}$

As evidenced by the need for California's and Congress' efforts, restructuring places renewables at risk. Listed to the right are the barriers to renewable energy development in competitive markets. ${ }^{24}$ In an unregulated environment, public utility planning subject to state regulatory oversight will tend to be replaced by strategic planning by private firms. ${ }^{25}$ Whether environmental costs from fossil fuels lead to special treatment for renewable resources is likely to depend on three factors: individual state goals and initiatives; political/public response to global warming or its perception; and the extent to which renewable technologies replace older, coal-fired plants.

If cost is the sole criterion in any restructuring proposal, then biomass (and all other renewable technologies) will suffer in the short run, if California's experience is any guide. One of the expected outcomes of deregulation is a fall in prices. However, since most renewables have not been able to bring their production costs to a competitive level, they may not be able to realize a price that covers their cost of production. Thus, their survival in the early stages will in part be based on incentives and credits such as the $1.5 \phi / \mathrm{kWh}$ REPC for biomass and wind and the 10 percent tax credit for geothermal and solar technologies. These serve to offset costs, at least until they are able to be cost-competitive with conventional technologies.

Renewables, however, may have a unique advantage if, as envisioned in a fully deregulated market, customers are allowed to choose their power supplier. It has been shown that consumers do make purchasing decisions based on elements other than cost. Provided the quality is the same, a consumer may decide to purchase "green" electricity or purchase power from a local generator to keep the profits in the community. ${ }^{26}$ The extent to which these added factors will affect biopower is unclear, but it does provide the industry with another incentive for future biomass development.

${ }^{23}$ Bumpers, Dale, U.S. Senator, 1997, Press Release, January 30.

${ }^{24}$ Nogee, Alan, 1996, Renewable Energy and Electric Utility Restructuring in the Mid-Atlantic Region: Risks and Opportunities, p. 9.

${ }^{25}$ Brennan,T., et al, 1996, A Shock to the System, p. 125.

${ }^{26}$ Brennan,et al., point out that, "Some analysts have suggested that with the proper pricing of transmission, the advantages of localized generation will be recognized; changing the mix of generation facilities from large generators serving wide areas to smaller, more localized plants will lead to a greater use of some forms of renewable technologies." 
Some states are already mandating competition in their electric industries. However, because a comprehensive Federal system has not been established, the approach and issues pertaining to deregulation are still being widely debated. Consequently, various solutions for the role of renewables are also being discussed. The box below summarizes some of these strategies. ${ }^{27}$ These scenarios demonstrate a fundamental reality: to ensure fair competition for renewables, developers need access to the grid, to utility market information, and to capital; and consumers need reliable information on product availability, cost, and performance. ${ }^{28}$

\begin{tabular}{|l||}
\hline Proposed Strategies for Renewables in a Deregulated Market \\
- $\begin{array}{l}\text { Expanding and increasing tax credits for renewables, } \\
\text { while eliminating all other preferences }\end{array}$ \\
Valuing environmental benefits and costs and alerting the \\
public to these issues \\
Demonstrating cost-competitiveness to attract capital, \\
because of a greater involvement of private power \\
developers \\
Instituting efforts such as the RPS and SBC
\end{tabular}

\footnotetext{
${ }^{27}$ Brennan, T., et al., and Morris, Gregory.

${ }^{28}$ Nogee, Alan, 1996, Renewable Energy and Electric Utility Restructuring in the Mid-Atlantic Region: Risks and Opportunities, p. 14.
} 


\subsection{FEEDSTOCK DEVELOPMENT}

According to the USDOE, biopower worldwide is projected to grow by approximately $30 \mathrm{GW}$ by the year $2020{ }^{29}$ The opportunities for export of American technology are clear, if that technology is technically demonstrated and economically competitive. This is expected to incorporate Integrated Gasification Combined Cycle (IGCC), co-firing, and steam generating technologies and a combination of residues and dedicated feedstocks as fuel. This section will discuss the future feedstock development and repowering opportunities for biomass. A forthcoming report will expand on these issues and discuss co-firing opportunities and emerging technologies.

\subsection{Feedstock Development}

Long before the 1992 EPAct was passed, DOE instituted a program to meet future biofuel needs. The Biofuels Feedstock Development Program (BFDP) was established in 1978 and has tried to link DOE-funded research with related state and private sector research and development activities. By 1995 , these linkages resulted in a nearly 100 percent research cost-sharing and coordination of efforts across the U.S. The program's mission has been defined as providing leadership in the development and demonstration of environmentally acceptable and commercially viable biomass supply systems. The BFDP set forth several goals:

- guarantee that new, profitable and environmentally acceptable cropping options exist for biomass producers

- guarantee that secure, affordable and sustainable supplies exist for biomass end-users

assure that the U.S. is capable of meeting up to 15 percent of its total primary energy demand from dedicated biomass crops

To achieve these goals, the BFDP is attempting to address the following issues:

- integrate and promote multiple objectives for agriculture, energy and the environment

- $\quad$ seek and foster the best research, development, and demonstration in the private, academic and government sectors

- ensure that information on biomass supply systems is accurate, understandable, and accessible

The BFDP is attempting not to only ensure that dedicated biomass crop technologies are available when and where needed, but also that the infrastructure for production and delivery of the biomass supplies is established in parallel. The BFDP's long-term feedstock development research includes focuses on two specific types of biomass resources, Short-Rotation Woody Crops (SRWC) and Herbaceous Energy Crops (HEC).

\subsubsection{Short-Rotation Woody Crop Research}

One of BFDP's objectives is to develop and refine short-rotation woody crop (SRWC) silviculture systems for the production of reliable, low-cost, high-quality, sustainable wood for fuel and fiber in the U.S. This task includes developing equipment systems to improve the efficiency and reduce the cost of producing and harvesting SRWC.

\footnotetext{
${ }^{29}$ DOE, 1996, DOE Biomass Power Program Strategic Plan 1996-2015, p. 7.
} 
The BFDP has supported woody crop research integrating traditional breeding, silvicultural research, and molecular genetics throughout the U.S. In the Pacific Northwest, a well-integrated research effort has led to the development of high-yielding (ca. 8-12 dry tons per acre per year) hybrid poplar cultivars adapted to the environmental, climatic, and biological constraints of the region. These poplars are being planted on almost 50,000 acres with more than double that amount anticipated to be planted within the next 5 years. In other parts of the U.S., yield improvement has not been as dramatic but steady progress is being made using a combination of genetic and silvicultural approaches.

The BFDP is gradually modifying and linking the ongoing research funded at several institutions to create regional woody crop development centers for the North Central, South, and Northeast regions. These are modeled after the successful integration efforts in the Pacific Northwest. At a minimum, each center will involve the optimum integration of silviculture, genetics, plant breeding, entomology and pathology. To the extent possible, new and ongoing research dealing with mechanization and harvesting, economic analysis, environmental studies, and demonstrations will also be linked with the regional crop development centers.

A current example is the effort of the New York Salix consortium described in section 6.1. This group is studying the development of willow for use in bioenergy applications. Its research has focused on soil conservation, integrated pest management, biodiversity and landscape ecology, farm diversification/rural development, production and processing system integration, energy conversion, emissions, ash utilization, and meeting energy consumer needs. ${ }^{30}$ Results from this work indicate that the willow production and utilization systems are environmentally and ecologically acceptable. The next phase focuses on overcoming the economic constraints. To accomplish this, the consortium is studying the cost of production and use, the value of environmental externalities, and potential government/public policy actions needed to help make using willow for bioenergy economically viable.

Another example is Minnesota's Wood Energy Scale-Up Project whose purpose is to track and monitor the economic costs of planting, maintaining, and monitoring large-scale commercial plantings of hybrid poplar. Data from these efforts will be used to develop reliable site productivity functions which will assist potential growers and purchasers to determine ways poplar supply and demand can be secured through developing markets. ${ }^{31}$

\subsubsection{Herbaceous Energy Crop Research}

The goal of herbaceous energy crop (HEC) research is to develop crops that can be economically produced on a wide variety of sites and readily and practically incorporated into conventional farming operations. Systematic screening studies in a variety of locations have shown that switchgrass can meet this goal in several regions of the U.S. While other herbaceous energy crop species may also be candidates, switchgrass was chosen for these demonstration purposes. It has a geographical range that covers most of the U.S. and portions of Canada and Central America and is found in diverse habitats ranging from Midwestern prairies to brackish marshes and open woods. The grass can be used both as a biofuel and as a forage crop, although optimal characteristics for each use differ. Switchgrass also has several positive environmental attributes including low nutrient use, low pesticide requirements, and a perennial growth habit.

\footnotetext{
${ }^{30}$ White, E.H., 1996, "Willow Biomass-Bioenergy Industry Development in New York: Sustainability and Environmental Benefits," pp. 60-67.

${ }^{31}$ Downing, M., 1996, "Large-Scale Hybrid Poplar Production Economics: 1995 Alexandria, Minnesota, Establishment Cost and Management," p. 467.
} 
As stated in section 6.2, the MnVAP cooperative is developing an integrated alfalfa processing and biomass energy system. The main product from the plant will be electricity, which was determined to be the highest-value use of the fibrous stem material. Its aim is to invigorate southwestern Minnesota's economy by maximizing the value added to alfalfa and returning the benefits of ownership to the rural community. ${ }^{32}$ In doing so, it becomes a prime example of sustainable development, because it promotes economic development in an environmentally beneficial manner.

\subsubsection{Environmental Research}

The objective of BFDP's environmental research is to develop site-specific regional data related to environmental parameters such as biodiversity, chemical fate, soil chemistry, erosion and surface water runoff, and plantation design. Possession of this information will facilitate the implementation of energy crop plantings at the field, landscape, and regional levels. Once the data are gathered, they can be used on a region, site, and species basis to document the sustainability and environmental benefits of energy crops as currently envisioned. These data will also provide a baseline and basis for improving the cultural systems to enhance the sustainability of energy crops.

Since the beginning of the BFDP, environmental acceptability and sustainability have been part of the selection criteria for identifying promising crops and production systems. Perennial crops have been favored over annual crops because of their ability to provide soil stability, nutrient retention, and reduced agrochemical requirements. Bird and small mammal surveys have been conducted in commercial and experimental plots to address biodiversity compared to traditional land uses. Results from some of these studies have shown switchgrass plantings can serve as habitat for some prairie songbirds whose populations are dwindling.

Another area of environmental research is carbon sequestration in soils by biomass crops. Carbon sequestration in soil is predicted to be an important means of reducing greenhouse gases. Assessing soil carbon changes is essential to developing greenhouse gas balances and determining the economic importance of potential carbon sequestration tax credits. Studies on Conservation Reserve Program sites planted with switchgrass have shown that soil carbon sequestration may be as much as 0.45 ton carbon per acre per year over the first 5 years in the top 120 inches of soil (McLaughlin, 1994). New studies collecting soil chemistry data at multiple sites in different regions will provide information on potential differences in soil carbon sequestration rates as a function of soil type, tree or grass species, management systems, harvesting regimes, and climate. The results of soil carbon studies can contribute to consideration of issues related to carbon tax credits, if these credits are ever offered.

${ }^{32}$ Campbell, Ken., 1996, "The Minnesota Agri-Power Project," pp. 68-74. 


\subsection{USDOE/USDA JOINT DEMONSTRATION PROJECTS}

As part of its Climate Change Action Plan (CCAP), the USDOE Biomass Power Program is working with the USDA to demonstrate and deploy cost-competitive renewable biomass power systems that spur rural economic development. This joint effort is also aimed at identifying the employment opportunities and environmental benefits associated with commercial biomass energy systems. To date, three USDOE/USDA projects are underway that use sustainable biomass feedstocks coupled with highefficiency technology: the New York Salix Project, the Minnesota Alfalfa Project, and the Iowa Switchgrass Project.

\subsection{New York Salix Project}

This project is a consortium of 25 partners whose objective is to commercialize a willow feedstock production system of 1,000 acres for $40 \mathrm{MW}$ of power production by the year 2002. The dedicated willow crops will be integrated with co-firing in the Northeast and northern Midwest. Participants include utilities, research groups, universities, and government agencies.

\section{Feedstock Objectives}

- obtain average yields above 7 dry tons/acre

- demonstrate production costs under $\$ 20 /$ dry ton at farm gate

- $\quad$ deliver dedicated feedstock supply at $<\$ 2.00 / \mathrm{MMBtu}$ by 2001

- $\quad$ plant 1,000 acres initially and $40,000-60,000$ acres by 2010

\section{Power Production Objectives}

- demonstrate automated and reliable feed systems

- determine conditions for NOx reductions

- demonstrate power production costs under $\$ 0.03 / \mathrm{kWh}$

- $\quad$ install co-firing capacity at two facilities

- $\quad$ produce a total of $37-47 \mathrm{MW}$ of biomass power

\section{Progress ${ }^{33}$}

- fuel delivery/processing system operational

- $\quad$ drying option addressed

- $\quad$ performed first-run system tests

- $\quad$ combustion tests on willow at Federal Energy Technology Center planned for spring '97

- $\quad$ field trials for willow ongoing

- initiated soil, fertilizer, site preparation, and clonal characteristics studies

\subsection{Minnesota Alfalfa Project}

This project aims to integrate an alfalfa processing plant with a fluidized bed gasification system potentially utilizing up to 180,000 acres of alfalfa for production of power and alfalfa-based products. Participants include: Northern States Power Company, University of Minnesota, Westinghouse, the Institute of Gas Technology, Carbona, and the Minnesota Valley Alfalfa Producers (MnVAP).

${ }^{33}$ Craig, Kevin and Michael Reed, 1996, "Results and Implications of Eleven Site Specific Biomass Feasibility Studies," p. 27. 


\section{Feedstock Objectives}

- $\quad$ annual alfalfa production of 750,000 tons using 180,000 acres

- $\quad$ provide alfalfa for power at a rate of 2,000 tons/day

\section{Power Production Objectives}

- $\quad$ production of $75 \mathrm{MW}$ of baseload electric power and alfalfa co-products through integrating a biomass gasification combined-cycle plant and an alfalfa processing facility

\section{Progress $^{34}$}

- demonstrated strong farmer interest in energy crop production, resulting in the formation of the MnVAP Cooperative

- commercial offering of a complete biomass-based gasification combined cycle plant in the Biomass Power for Rural Development program

- $\quad$ helped to refine vendor estimates of cost and efficiency of biomass IGCC systems

- $\quad$ quantified environmental benefits of alfalfa energy crops to wildlife, erosion, and water quality

- currently negotiating power purchase contract with Northern States Power

\subsection{Iowa Switchgrass Project}

The objective of this project is to develop energy crop markets in southern Iowa. To do so, it plans to retrofit an existing plant to produce $35 \mathrm{MW}$ of power using switchgrass grown on 40,000 Conservation Reserve Program (CRP) acres, and it plans to investigate the potential of gasification up to $6 \mathrm{MW}$. Participants include: Chariton Valley Resource Conservation and Development, IES Utilities, Iowa Farm Bureau Federation, R.W. Beck Energy Research Corporation, Black and Veach, Iowa State University, Iowa Energy Center, Iowa Department of Natural Resources, Natural Resources Conservation Service, Consolidated Farm Services Agency, and Soil and Water Conservation Districts.

\section{Feedstock Objectives}

- establishment of 40,000 acres of dedicated switchgrass in southern Iowa

\section{Power Production Objectives}

- production of $35 \mathrm{MW}$ of biomass-based generating capacity by the year 2000

\section{Progress $^{35}$}

- a study concluded that energy crops can be cost-competitive with other energy sources in the future

- participants concluded that it is technically feasible to co-fire switchgrass at 5 percent with coal; power may also be generated by coupling a biomass gasifier to a GE Frame $6 \mathrm{~B}$ gas turbine

\footnotetext{
${ }^{34}$ Op. cit.

${ }^{35}$ Ibid, pp. 26-27.
} 
So far, these studies are striving to accomplish two things: 1) demonstrate that applications exist where biomass-based systems are economically competitive; and 2) reduce the uncertainty of capital costs associated with biomass-based systems. 


\subsection{CO-FIRING}

Co-firing is the simultaneous combustion of different fuels in the same boiler. Biomass is a well-suited resource for co-firing with other solid fuels, primarily coal, as an acid rain and greenhouse gas emission control strategy. Co-firing is a fuel-substitution option for existing fuel capacity, and is not a capacity expansion option like repowering. A biomass co-firing retrofit in an existing coal boiler will require modifications or additions to fuel handling, storage and feed systems. These can be accomplished using commercially available equipment. Co-firing biomass with coal has been successfully demonstrated and is currently practiced in the full range of coal boiler types, including pulverized coal boilers, stokers, cyclones, and bubbling and circulating fluidized beds. This section will provide a general background on biomass co-firing and insight into key issues that apply specifically to markets in the United States.

\subsection{Benefits of Co-firing}

Coal-based electricity generators represent about 43 percent of the total generation capacity in the United States. ${ }^{36}$ These power plants are experiencing increasing pressure to reduce operating costs as well as $\mathrm{SO}_{2}$, $\mathrm{NO}_{x}$, and possibly even $\mathrm{CO}_{2}$ emissions. Co-firing biomass at these existing coal-fired power plants is one possible cost-effective environmental compliance option. Coupled with the need of industrial generators of biomass residues (generally clean wood byproducts or remnants) to dispose of those residues, co-firing offers the potential for solving several problems at potentially modest investment costs. In most U.S. power plants where biomass co-firing systems have been implemented, reducing production costs has been the primary driver. Co-firing installations are presently found in areas where the cost of coal is high relative to the cost of available biomass residues. Thus, the key to co-firing projects has been locating competitive, reliable supplies of biomass in quantities large enough to pay off the retrofit investment in an acceptable period of time ( 3 years or less in most cases).

The list of potential benefits associated with biomass co-firing includes:

- $\quad$ Reduced Fuel Costs--Savings in overall production costs can be achieved if inexpensive biomass fuel sources are available. The price of biomass, on a heat basis (cost per MMBtu), must be low enough compared to the price of the existing coal supply to compensate for 1) moderate increases in operating costs incurred due to the addition of biomass storage and processing equipment, and 2) slight decreases in boiler efficiency. Under most circumstances, boiler efficiency will decrease as the volume of biomass increases due to the higher moisture content of biomass relative to coal. In general, the amount of biomass used should be adjusted in order to limit boiler efficiency decreases to less than 1 percent. The proportion of biomass allowable to maintain efficiency decreases of less than 1 percent will depend on the quality of the biomass fuel, particularly its moisture content. Based on co-firing experience and testing in the U.S., efficiency losses can be limited to about 1 to 2 percent for co-firing biomass with 40 to 50 percent moisture content, at rates as high as 10 percent of the total heat input. ${ }^{37}$ Biomass fuel supplies will need to be available at prices 20 percent or more below current coal prices.

- Market-Ready Renewable Energy Option--For co-firing, technology development is much less of an issue than resource economics and availability. Biomass co-firing with coal is practiced at a

\footnotetext{
${ }^{36}$ Energy Information Administration, 1996, Inventory of Power Plants in the United States, DOE/EIA-0095(96), Dec., p.19.

${ }^{37}$ Tillman, David A., Dale Bradshaw, and Evan Hughes, 1996, Fuel Blending and Switching for NOx Control Using Biofuels with Coal in Cyclone Boilers, Foster Wheeler Environmental Corp./Tennessee Valley Authority/ Electric Power Institute.
} 
handful of utility-scale boilers (Tennessee Valley Authority, Tacoma Public Utilities, Northern States Power, New York State Electric and Gas, the Southern Company) and at many industrial sites, primarily in the forest products industry. Retrofits require commercially available fuel handling and boiler equipment. Engineering and design issues are well understood.

- Implementation Costs/Requirements--Co-firing system retrofits require small capital investments relative to most other renewable power generation technologies. This should make co-firing a competitive option for utilities interested in increasing their "green" power capacity, and could help them meet the renewable requirements of proposed generation portfolios with minimized capital investments. Costs as low as $\$ 100$ per $\mathrm{kW}$ of biomass power can be achieved for stokers, fluidized beds, and cyclone boilers, especially at low co-firing percentages (less than 3 percent on a heat basis). Retrofits for high percentage co-firing (up to 15 percent of the total heat input) at a pulverized coal (PC) boiler typically range from $\$ 300$ to $\$ 500$ per $\mathrm{kW}$ of biomass power. This is significantly higher than the cost of the other boiler types. This is due primarily to fuel supply system modifications required to allow high-percentage co-firing, and to the cost of fuel processing equipment required to reduce the biomass particles to a size small enough to allow complete burn-out in a PC boiler.

- Continuous, Base-Load Power Generation Capability--Unlike most renewable electricity generation technologies, biomass co-firing-based systems are capable of operating as base-load capacity and therefore have the advantage of higher capacity factor operation. This helps provide quicker pay-offs of the initial capital investment.

- $\quad$ Flexible Fuel Technology Option for Intermittent Use--The systems described in this report are designed to be flexible. They can be run during selected times or shifts. The biomass-fired systems are independent of the coal-fired system. Since the targeted existing power stations were originally configured to operate in a coal-only mode, if problems arise with the biomass system, rated plant output can still be achieved using coal.

- $\quad$ Fuel Diversification--Having the ability to operate using an additional fuel source provides a hedge against price increases for existing fuel supplies. Possible increased administration costs involved with purchasing multiple fuel supplies should be considered when evaluating the value of this benefit.

Atmospheric Environment Improvement--Atmospheric environmental benefits associated with using biomass resources to replace fossil fuels (primarily coal) include reductions in net emissions of greenhouse gases (carbon dioxide, $\mathrm{CO}_{2}$ ) and acid rain precursors (sulfur dioxide, $\mathrm{SO}_{2}$, and possibly nitrogen oxides, NOx). Biomass reduces sulfur dioxide emissions due to its low sulfur content relative to coal. Sulfur dioxide and net carbon emissions are reduced in proportion to the amount of heat input obtained from biomass. Because biomass absorbs as much carbon dioxide during its growing cycle as is emitted from a boiler when it is burned, it generates nearly no net $\mathrm{CO}_{2}$ emissions when biomass production is undertaken on a sustainable or "closed-loop" basis. This makes biomass one of the most practical strategic options for complying with restrictions on generation of greenhouse gases. Fossil $\mathrm{CO}_{2}$ reductions are currently being pursued by utilities in the U.S. on a voluntary basis through the Climate Challenge program. These utilities are able to "bank" their fossil $\mathrm{CO}_{2}$ emission reductions for future use in the event that legislation is passed which creates market value for $\mathrm{CO}_{2}$ reductions. 
- Waste Diversion from Landfills--Using urban wood residues as a fuel reduces landfill material and consequently extends landfill life. For industries served by electric utilities, rising tipping fees and restrictions on landfill use represent an opportunity for the power company to assist its industrial customers while obtaining a low-cost alternative fuel. Firing biomass in boilers with pollution control can reduce burning of wood residues in uncontrolled furnaces (e.g., wigwam burners) and hence provides another means of reducing emissions.

\subsection{Key Issues for Consideration}

\section{$\underline{\text { Keys to a Successful Co-firing Project }}$}

From a station operating and performance perspective, the goal for a successful biomass co-firing project is to obtain cost and emissions reductions. The objectives of a co-firing project should include:

- obtaining sufficient supplies of biomass fuels at prices 20 percent or more below current coal prices,

- designing and installing biomass fuel receiving, processing, and combustion systems to minimize boiler efficiency losses to less than 1 percent,

- $\quad$ providing reliable and automated operation,

- $\quad$ avoiding impact on equipment and operations downstream of the boiler, and

- obtaining value from emission reductions in $\mathrm{SO}_{2}, \mathrm{CO}_{2}$, and/or $\mathrm{NOx}$.

\section{Potential Barriers for Co-firing Projects}

In addition to the potential benefits associated with a co-firing application, there are also a number of potential barriers or hurdles which must be considered and resolved prior to implementing a co-firing retrofit project. The most prominent of these barriers are:

- Resource Constraints--Low-cost biomass residues are normally obtained from agricultural industries, urban waste, or forest product industries such as lumber, furniture, and pulp and paper. Acquiring a reliable supply of residues at a price low enough to make the retrofit investment economical will be a key component of any near-term co-firing project. Due to the costs associated with transporting biomass, supplies will usually need to be obtained within a distance of 50 to 100 miles from the power plant. Competing uses for these resources can also drive prices up and make the economics for co-firing less attractive. In the future, the development of economical biomass feedstocks from energy crops may help reduce supply constraints.

- Coal Abundance and Price---Under present economic and legislative conditions, the primary motivation to co-fire is fuel supply cost reduction. This requires the availability of a large and reliable supply of biomass at a discounted cost compared to coal. Until environmental legislation for emissions reductions internalize more economic incentives to utilize biomass, availability of an abundant supply of inexpensive coal will represent a significant hurdle for biomass co-firing opportunities in some areas of the U.S.

- Marketability of Commingled Ash--According to the American Coal Ash Association (ACAA), in 1995 member utilities utilized approximately 25 percent of their fly ash as a byproduct, and 52 
percent of that was sold for use as a concrete additive. ${ }^{38}$ For power stations who presently sell their fly ash, one of the key factors to consider is the effect of co-firing on ash marketability. The profits from fly ash sales are significant and the ability to sell fly ash is an essential part of plant operations. In applications where coal fly ash is suitable for use as a concrete admixture prior to co-firing, physical and chemical properties of the ash from co-firing with most common biomass feedstocks will also meet the property requirements for use in the high-value concrete additive market. However, there is concern as to whether use of a solid fuel other than coal (even a clean fuel such as most biomass) will prevent the ash from meeting existing ASTM coal fly ash standards for concrete admixtures. In addition, underutilization of fly ash in some areas of the U.S. leads to the availability of large volumes of non-co-fired ash for ash buyers to purchase. There is also competition from other concrete admixtures. The combination of these factors results in the reluctance of some power plant management to consider co-firing. Efforts to alleviate these concerns by developing new ASTM standards (or altering existing standards) are under consideration, and other high-value markets for coal ash (and co-fired ash) are being sought.

- Low economic incentives for environmental benefits--Utility power plants across the nation are coming under increasing pressure from competitors and customers to cut costs and deliver electricity at competitive prices. At the same time, Federal regulations such as the Clean Air Act Amendments (CAAA) of 1990 require stricter limits on utility stack emissions. A market-based system which attaches an economic value to reduced $\mathrm{SO}_{2}$ emissions has been established. While this helps the economics of a co-firing project, the present market value of those reductions alone (about $\$ 90$ per ton of reduced $\mathrm{SO}_{2}$ emissions per year) does not make a substantial impact on the overall economics. Global agreements on limiting greenhouse gases are being implemented in the U.S. on a voluntary basis; however, present legislation provides little or no concrete economic incentives to do so. Until the environmental benefits associated with biomass and other renewables become economically rewarding to power producers, they will continue to opt for fossil-based generation except in niche applications where renewables presently make economic sense.

\subsection{Installation Requirements and Costs}

The key elements of a co-firing system retrofit will include all or some of the following, depending on the level of co-firing to be implemented and the existing conditions at the plant:

- Receiving: truck scales, tipper, conveyors

- $\quad$ Processing: reclaim feeder, conveyors, scrap metal separator, hoggers and disc feeders

- $\quad$ Buffer Storage: 18-hour storage bin fed by pneumatic transport from hoggers

- $\quad$ Fuel Metering and Feed to Boiler: collecting conveyors, meters and pneumatic transport

- Injection Ports: dedicated or shared burners for biomass injection

Capital costs for co-firing retrofits depend on many factors. A single-shift unloading and processing operation with a high degree of automation can range in cost from $\$ 300$ to $\$ 500$ per $\mathrm{kW}$ of biomass power ${ }^{39}$ for a pulverized coal boiler. Such a system is shown in Exhibit 7.3-1. An automated approach can

\footnotetext{
${ }^{38}$ Brendel, G.F., A.M. DiGioia, and S.S. Tyson., 1996, “Developing an Effective CCB Marketing Program,” Proceedings: Twelfth International Symposium on Management \& Use of Coal Combustion Byproducts, Vol. 3, p.94-18.

${ }^{39}$ Costs are stated on a per $\mathrm{kW}$ of biomass power capacity basis, not based on the entire plant capacity. For example, using a cost of $\$ 350 / \mathrm{kW}$ for a co-firing retrofit designed to supply $15 \%$ of the heat input for a $100 \mathrm{MW}$ plant, the estimated retrofit cost would be $(0.15) \times(100$ $\mathrm{MW}) \times(\$ 350 / \mathrm{kW}) \times(1000 \mathrm{~kW} / \mathrm{MW})=\$ 5.25$ million .
} 
EXHIBIT 7.3-1

High Co-firing Rate Retrofit for a Pulverized Coal Boiler

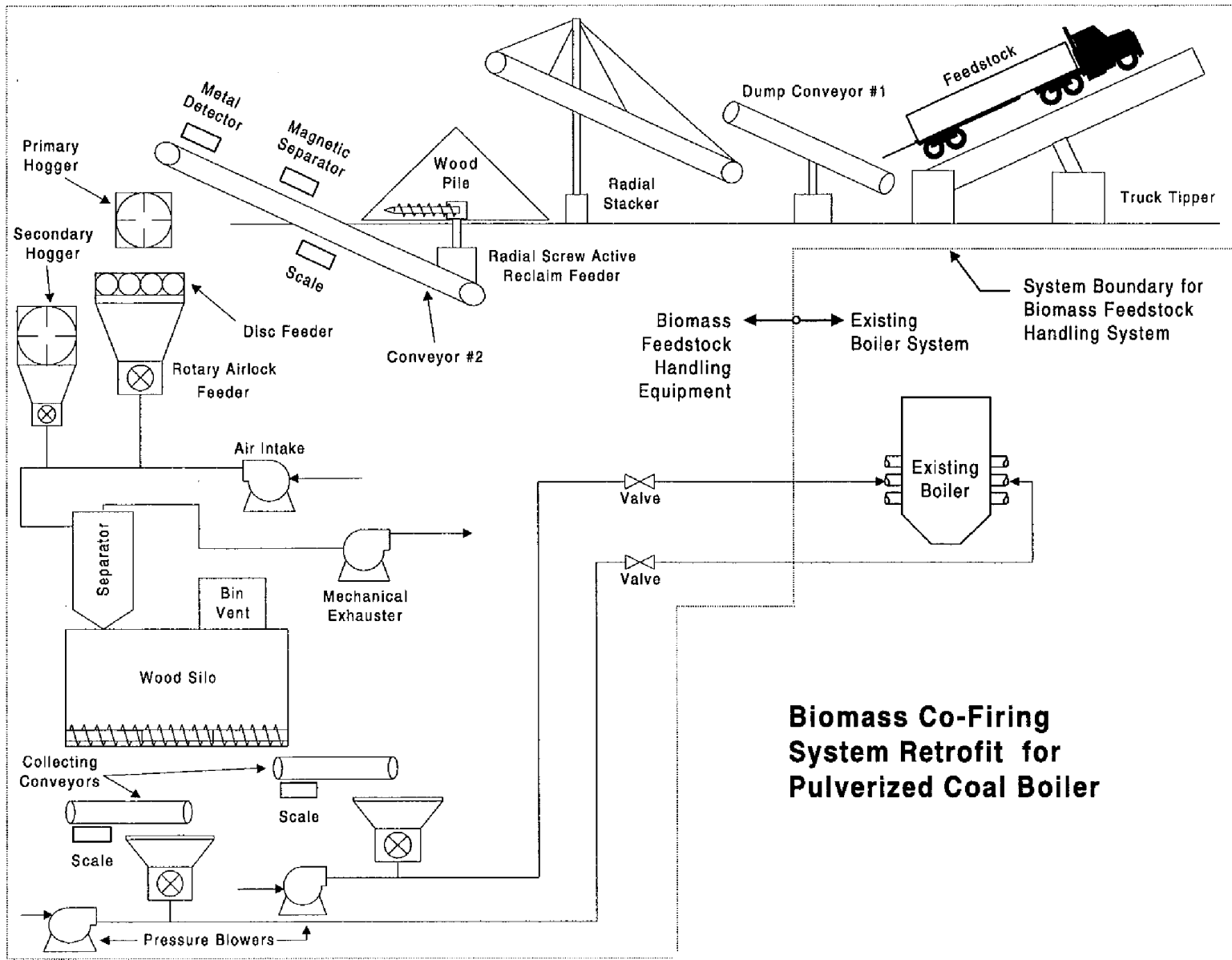

provide significant operating cost savings, particularly in operating labor required. Cheaper systems could utilize self-unloading vans and bulldozers or front-end loaders for receiving and pile management. Cofiring at low rates (less than 3 percent on a heat basis) and utilizing existing oversized coal processing (pulverizers, conveyors, etc.) and fuel injection systems to handle biomass feedstocks can also reduce costs. To avoid problems in the existing coal handling and supply systems, high-percentage co-firing usually requires a separate and more expensive feed system for biomass which operates in parallel with existing coal supply systems.

It should be recognized that co-firing retrofit costs are extremely site-specific and can range from $\$ 100$ to $\$ 700$ per $\mathrm{kW}^{40,41}$ depending on many factors including boiler type, amount of biomass co-fired, site layout, existing receiving equipment at the plant, complexity of handling and processing system design, nature of the delivered biomass feedstock, etc.

\footnotetext{
${ }^{40}$ Antares and Parsons, 1996, Utility Coal-Biomass Co-firing Plant Opportunities and Conceptual Assessments, prepared by Antares Group Inc., Landover, MD and Parsons Power, Reading, PA, for the Northeast Regional Biomass Program and the U.S. Department of Energy.

${ }^{41}$ Ebasco, 1993, Wood Fuel Cofiring at TVA Power Plants--Volume 1: Retrofitting Existing Boilers to Co-fire Wood Fuel, prepared by Ebasco Environmental for Electric Power Research Institute, Contract 3407-1, June.
} 


\subsection{Co-firing Experience in Different Boiler Types}

EXHIBIT 7.4-1

Previous, Existing, or Planned Biomass Co-firing Applications ${ }^{42}$

\begin{tabular}{|c|c|c|c|}
\hline PLANT & FUEL & SIZE & TECHNOLOGY \\
\hline \multicolumn{4}{|c|}{ Cyclone Boilers } \\
\hline $\begin{array}{l}\text { Northern States Power } \\
\text { Allen S. King Station } \\
\text { Minneapolis, Minnesota }\end{array}$ & $\begin{array}{l}\text { Coal/waste } \\
\text { wood (lumber) }\end{array}$ & $560 \mathrm{MWe}$ & Cyclone \\
\hline $\begin{array}{l}\text { Otter Tail Power Co. } \\
\text { Big Stone City, } \\
\text { South Dakota }\end{array}$ & $\begin{array}{l}\text { Coal/RDF/tires/ } \\
\text { waste oil/ag. refuse }\end{array}$ & $440 \mathrm{MWe}$ & Cyclone \\
\hline $\begin{array}{l}\text { Tennessee Valley Authority } \\
\text { Allen (1) \& Paradise (2) Stations } \\
\text { Memphis \& Dunmore, Tennessee }\end{array}$ & $\begin{array}{l}\text { 1. Coal/waste wood and } \\
\text { coal/wood/tires } \\
\text { 2. Coal/waste wood }\end{array}$ & $\begin{array}{l}\text { 1. } 176 \mathrm{MWe} \\
\text { 2. } 700 \mathrm{MWe}\end{array}$ & $\begin{array}{l}\text { 1. Cyclone } \\
\text { 2. Cyclone }\end{array}$ \\
\hline \multicolumn{4}{|c|}{ Fluidized Bed Boilers } \\
\hline $\begin{array}{l}\text { Tacoma City \& Light } \\
\text { Tacoma Two Station } \\
\text { Tacoma, Washington }\end{array}$ & $\begin{array}{l}\text { Coal/RDF/wood } \\
\text { waste }\end{array}$ & $2 \times 25 \mathrm{MWe}$ & $\begin{array}{l}\text { Bubbling } \\
\text { Fluidized Bed }\end{array}$ \\
\hline $\begin{array}{l}\text { I/S Midtkraft Energy Co. } \\
\text { Grenaa Co-Generation Plant } \\
\text { Grenaa, Denmark }\end{array}$ & Coal/straw & $150 \mathrm{MWe}$ & $\begin{array}{l}\text { Circulating } \\
\text { Fluidized Bed }\end{array}$ \\
\hline \multicolumn{4}{|c|}{ Pulverized Coal } \\
\hline $\begin{array}{l}\text { GPU GENCO } \\
\text { Shawville Station } \\
\text { Johnstown, Pennsylvania }\end{array}$ & Coal/waste & $130 \mathrm{MWe}$ & Pulverized Coal \\
\hline $\begin{array}{l}\text { Iowa Electric Light \& Power } \\
\text { Sixth Street Station } \\
\text { Marshalltown, Iowa }\end{array}$ & $\begin{array}{l}\text { Coal/agricultural } \\
\text { refuse }\end{array}$ & $\begin{array}{l}3 \text { Units } \\
6-15 \mathrm{MWe}\end{array}$ & Pulverized Coal \\
\hline $\begin{array}{l}\text { Tennessee Valley Authority } \\
\text { Kingston Station } \\
\text { Oakridge, Tennessee }\end{array}$ & Coal/waste wood & $150 \mathrm{MWe}$ & Pulverized Coal \\
\hline $\begin{array}{l}\text { EPON } \\
\text { Centrale Gelderland } \\
\text { Netherlands } \\
\end{array}$ & $\begin{array}{l}\text { Coal/waste } \\
\text { wood (demolition) }\end{array}$ & $602 \mathrm{MWe}$ & Pulverized Coal \\
\hline $\begin{array}{l}\text { I/S Midtkraft Energy Co. } \\
\text { Studstrupvaeket, Denmark }\end{array}$ & Coal/straw & $150 \mathrm{MWe}$ & Pulverized Coal \\
\hline $\begin{array}{l}\text { Uppsala Energi AB } \\
\text { Uppsala, Sweden }\end{array}$ & $\begin{array}{l}\text { Coal (peat)/ } \\
\text { wood chips }\end{array}$ & $\begin{array}{l}200 \mathrm{MWe} \& \\
320 \mathrm{MWt}\end{array}$ & Pulverized Coal \\
\hline \multicolumn{4}{|c|}{ Stoker Boilers } \\
\hline $\begin{array}{l}\text { New York State Elec \& Gas } \\
\text { Hickling Station } \\
\text { Big Flats, New York }\end{array}$ & $\begin{array}{l}\text { Coal/waste wood and } \\
\text { coal/tyres }\end{array}$ & $\begin{array}{l}100,000 \\
\mathrm{~kg} / \mathrm{h} \text { steam }\end{array}$ & Stoker \\
\hline $\begin{array}{l}\text { New York State Elec \& Gas } \\
\text { Jennison Station } \\
\text { Bainbridge, New York }\end{array}$ & $\begin{array}{l}\text { Coal/waste wood and } \\
\text { coal/tyres }\end{array}$ & $\begin{array}{l}91,000 \\
\mathrm{~kg} / \mathrm{h} \text { steam }\end{array}$ & Stoker \\
\hline
\end{tabular}

\footnotetext{
${ }^{42}$ Winslow, J.C., S.M. Smouse, J.M. Ekmann, et. al., 1996, Cofiring of coal and waste, IEA Coal Research, London, IEACR/90,
} 


\begin{tabular}{|l|l|l|l|}
\hline PLANT & FUEL & SIZE & TECHNOLOGY \\
\hline $\begin{array}{l}\text { Northern States Power } \\
\text { Bay Front Station } \\
\text { Minneapolis, Minnesota }\end{array}$ & $\begin{array}{l}\text { Coal/waste wood } \\
\text { (lumber) }\end{array}$ & $560 \mathrm{MWe}$ & Stoker \\
\hline
\end{tabular}

Biomass co-firing is applicable to most coal-fired boilers used for power generation. Retrofits for coalfired stokers, cyclones, and fluidized bed boilers are potentially simpler and less expensive than those for pulverized coal. However, pulverized coal boilers are a very important application because they are the most widely used steam generating system for coal-fired power generation in the U.S. They also account for the majority of plants affected by the 1990 Clean Air Act Amendments (CAAA), which contain provisions for reducing the emissions of sulfur dioxide $\left(\mathrm{SO}_{2}\right)$ and $\mathrm{NO}_{\mathrm{x}}$ from electric generating units. Commercial-scale biomass co-firing experience has been gained in each of these types of boilers. Details from some of the previous, existing, or planned co-firing installations are shown in Exhibit 7.4-1. Through these commercial applications, co-firing with biomass has been proven to be technically feasible for all major types of coal-fired boilers. If biomass resources are available within 50 to 100 miles of a coal-fired power station in sufficient quantities and at low enough prices, co-firing should be given serious consideration as an environmental enhancement and cost reduction strategy.

\subsection{Co-firing Summary}

Biomass co-firing is a greenhouse gas and acid rain precursor emissions reduction strategy which can also offer economic benefits for the power producer by decreasing fuel and environmental costs. Under the right set of circumstances, where several of the potential advantages of co-firing may be capitalized upon, co-firing can be an effective means of improving the competitiveness of an existing coal-fired facility-helping the plant remain on-line in today's competitive power market. Local communities could also benefit from increased jobs created for transporting and handling the biomass feedstocks, raising and harvesting dedicated energy crops, and reducing the burden on existing landfills. Co-firing is presently economically attractive for plants which 1) can obtain supplies of biomass feedstocks for a significant discount when compared to their primary fuel, 2) operate to supply base-load or intermediate-load power (high capacity factor plants), 3) where existing equipment and personnel can be used to reduce the capital costs of the retrofit, or 4) have existing oversized coal processing equipment that can be used for supply and partial processing of biomass feedstocks. Changes in the valuing of the environmental and rural economic development benefits of biomass co-firing, especially the greenhouse gas reduction benefits, have significant potential to make it an attractive option for an larger number of power producers. 


\subsection{REPOWERING}

Repowering covers a broad range of technologies. This is because repowering often represents a unique upgrade of a plant to combined cycle operation. Many general repowering strategies have been implemented or proposed, but application inevitably involves site-specific adjustments and engineering. The goal of this section is to define some general forms of repowering, and suggest schemes which may be compatible with using biomass as the repowering fuel. The feasibility of these strategies in any given application would require additional research, but the reader should keep in mind that repowering offers a creative, and potentially profitable means of introducing advanced biomass technologies into the commercial market place.

\section{Definition of Repowering}

Repowering is defined by the DOE as "refurbishment of a plant by replacement of the combustion technology with a new combustion technology, usually resulting in greater performance and capacity." However, the industry has expanded this definition to allow the consideration of a wide array of repowering technologies and cycle configurations. Typically, repowering configuration can be further subdivided into two major categories: ${ }^{43}$ Partial or Boiler Repowering, and Station Repowering.

Partial or Boiler Repowering - Augmentation of the existing steam cycle without completely replacing current steam generating facilities (usually a boiler). This type of repowering typically retains the major parts of the existing steam cycle and the existing power generation infrastructure. This can be accomplished through boiler modification, the addition of a combustion turbine and/or heat recovery steam generation, or a combination of the two.

Station Repowering - Replacement of the existing steam generator (usually a boiler) with alternate methods of steam generation. Depending on the severity of the overhaul, some part of the existing power generation and/or transmission infrastructure is retained.

Industry has identified a third type of repowering, Site Repowering. However, as usually defined, site repowering would allow for little salvage of existing power plant facilities and equipment. In fact site repowering is only related to the other two types of repowering in that it may provide advantages over a greenfield development project. Specifically, reduced permitting requirements and infrastructure costs could be realized.

\section{The Motivation to Repower}

The desire to generate power more competitively by lowering power production costs strongly motivates power producers in today's electricity market. Deregulation is likely to increase pressure on utilities and independent power producers to justify new investments more carefully and ensure that existing assets are leveraged to the fullest extent possible. Repowering has emerged as a strategy to meet these two goals. Industries that own cogeneration assets are also considering this move, but with a different motivation. Their interest in repowering is usually motivated by the need to replace aging equipment and increase steam generation for expanded operations.

\footnotetext{
${ }^{43}$ Antares Group, Inc., 1996, Repowering Applications and Markets for Biomass Fuel Integration and Augmentation, prepared for U.S. Department of Energy/National Renewable Energy Laboratory, July 22.
} 


\subsection{Repowering with Biomass}

For biomass to be considered as a choice worthy of the investment and risk, it must provide a combination of the above benefits. Further, until some of the environmental benefits associated with using biomass $\left(\mathrm{CO}_{2}\right.$ neutrality for example) are explicitly valued, the performance of a plant repowered with biomass will have to exceed the economic performance of plants repowered using fossil fuels (natural gas is currently setting the standard although coal gasification technology has emerged as a contender). This reality has as much to do with the added complexities of handling/gasification equipment for biomass as it does with the current low cost and availability of natural gas. However, biomass may still be a competitive choice when several factors converge in its favor. These include:

- Availability of residue fuels at very favorable prices and in sufficient quantities can powerfully influence the bottom line. Power generators inside and outside of the forest products sector are looking to take advantage of this potential resource. In areas where natural gas is not available or prices are high, biomass may be an economically justifiable choice.

- Potential improvements to a station's environmental profile. Addition of biomass generating resources at coal-fired stations has the potential to reduce $\mathrm{SO}_{x}$ and $\mathrm{CO}_{2}$ emission factors on nearly a Btu-for-Btudisplaced basis. Under certain conditions, $\mathrm{NO}_{\mathrm{x}}$ emissions may also decline.

- Potential to improve overall plant operations. As a special case, industries that already use biomass as a fuel source can use emerging high-efficiency conversion technologies to increase their level of selfgeneration by as much as a factor of two. In some cases, there will be sufficient capacity gains to enable them to market excess power.

- Community support for biomass can translate to a competitive advantage. Consumers that value the unpriced benefits of "green" generation capability may translate those into economic terms that affect the bottom line or into regulatory requirements that give biomass a competitive edge.

Several repowering configurations are well suited to biomass fuel integration or augmentation.

Repowering in the U.S. has typically included replacing an existing boiler with a heat recovery steam generator (HRSG) and combustion turbines to produce a very high efficiency combined cycle. In most cases, the fuel of choice has been natural gas although pilot clean coal projects are successfully using gasified coal. Similar success is expected using biomass feedstocks.

While this (HRSG) configuration has a great deal of merit, there are several variations on the combined cycle theme that may offer some special advantages for biomass, especially in the near to mid term. These include parallel cycles and feedwater heating repowering. Several factors favor these choices for biomass integration relative to other repowering options: lower plant integration risk and system overhaul expenses, favorable capacity and efficiency gains, and scale suitability.

\subsection{Important Repowering Option Evaluation Criteria}

Many factors will be considered when examining which type of repowering is the best for a particular plant. These include, incremental capacity requirements, production costs, investment capital required, fuel selection, regulatory status and related environmental concerns. A plant owner's decision on these issues will help define the goals for a repowering effort and influence the choice of repowering technology and its integration. To more fully explore the potential impact, a list of major considerations and relevant 
explanations is provided below. The factors that relate to the goals for repowering are presented first and then other technical and economic factors are covered.

The owner's goals for repowering:

\section{The current and desired capacity/heat rate of the unit}

The repowering option most appropriate for a particular application depends on the existing and desired capacity of a unit. In general, options that tend to yield larger capacity increases typically experience the greatest increase in cycle efficiency. This is due largely to the completeness with which these configurations use available thermal energy, both in the form of gas turbine shaft power and recovered waste heat. For biomass, there is no technical limit to the size of the capacity addition, but there will always be economic and logistic limits to the addition. These limits are a function of the efficiency with which the technology converts biomass feedstocks to power and the availability of the biomass resource.

\section{The current and target production costs for the unit}

Repowering can reduce production costs by lowering the heat rate, reducing operating manpower requirements, reducing maintenance expenses, and reducing fuel costs. The choice of technology and fuel will strongly influence these factors: Heat rate improvements can reach 30 percent coupled with some reduction in O\&M costs on a $\mathrm{mil} / \mathrm{kWh}$ basis.

\section{The emission requirements of the unit and permitting considerations}

Emissions reductions are not usually the primary reason for repowering a unit. However, reductions in $\mathrm{SO}_{\mathrm{X}}$ and $\mathrm{NO}_{\mathrm{X}}$ emissions, and the potential savings in permitting lead times relative to a greenfield development may provide an additional incentive for undertaking a repowering project. Specifically, some repowering candidates may be in areas designated as non-attainment of primary or secondary ambient air quality standards. Facilities located in these areas, by virtue of repowering, may generate tradeable $\mathrm{NO}_{\mathrm{x}}$ and $\mathrm{SO}_{\mathrm{x}}$ emissions credits. Trading programs are under development across the United States, but the Northeast (also an area rich in biomass resource) appears especially interested. In fact, several utilities in this area have already begun programs to co-fire biomass at some of their coal-burning facilities. However, with respect to repowering, several court rulings have made it important to consider a wide range of nonemissions-related factors in determining a plant's regulatory requirements. These include the total cost of the repowering, and in the case of clean coal technology, the type of repowering. Thus, even in situations where emissions reductions are not of primary importance, a complete examination of a plant's current and future emissions specifications should be part of any repowering project.

There is also the potential to reduce some scheduling and site licensing problems. Avoiding permitting costs can represent a significant savings, but the extent to which financial risk is mitigated is often unquantifiable until the project is completed.

\section{Other Key Decision Factors}

There are a number of other factors which will need to be addressed when considering repowering options.

\section{Capital expenditures and anticipated costs}

According to the September/October 1995 issue of the EPRI Journal in an article entitled "Plant Repowering," "Using already established sites and existing facilities can give repowering projects substantial savings (20-40\%) over new construction at a greenfield site ..." These potential savings drive the current interest in repowering. Among the repowering options, investment requirements range from $\$ 100$ to $\$ 2,500$ per $\mathrm{kW}$. If capital is highly constrained, the repowering choices will be narrowed to the options that provide a more modest increase in capacity and require less modification to the current system. 


\section{The steam cycle configuration/conditions of the existing unit}

Many repowering situations require some matching of existing steam cycle parameters, such as steam turbine design inlet pressures and temperatures. Therefore, the ability of a particular option to fulfill the needs of the modified steam cycle is of great importance. In addition, for technical and economic reasons, certain boiler types are better suited to some types of repowering than to others.

\section{Spatial constraints}

Most repowering options require moderate increases in plant space. For example, combustion turbines coupled to heat recovery steam generators may require as little as two additional acres of space (this does not include any space required for gasification facilities if an IGCC is used). Other more complex configurations may require considerably more space. The importance of this factor will be highly dependent on a plant's individual layout and usable space.

\section{Current and desired fuel, and fuel flexibility}

The current and desired fuel types are of primary importance in considering a particular repowering option. For example, some forms of repowering are incompatible with retention of a coal-fired boiler. Another consideration is the capacities of the fuel delivery and handling systems. Typically, these systems will require some modification and in the extreme case, new systems may need to be purchased. The extent of these modifications and/or replacements will depend on the configuration of a particular project. All of these factors take on varying degrees of relevance depending on cost expectations and desired mitigation of fuel price risk.

\section{The condition and age of any equipment to be retained}

As mentioned in the definitions of partial and station repowering, some plant equipment is usually retained. In fact, one of the primary goals of any repowering project is to retain existing steam turbines and generator assemblies. However, in most cases some refurbishment to retained equipment (such as upgrading turbine blades and rewinding the generator) will be required. The condition in which the retained equipment has been maintained therefore has a direct impact on the overall economics of a repowering project.

\subsection{Repowering Options}

The number and configurations of repowering options are expanding. Based on previous work done by the Antares Group, ${ }^{44}$ the following section presents specific options that may be well suited to biomass applications.

\subsubsection{Substitute Combustion Turbine/Heat Recovery Steam Generator}

As stated previously, CT/HRSG substitution is currently the domestic power industry's favored repowering option. Fired by natural gas, these systems offer rapid load change and start-up capability, high reliability, low emissions, and high efficiencies. In fact, this type of repowering could be considered the standard by which all other options must be measured. The attractiveness of this option with respect to gasification is enhanced by the repowering market's experience with projects such as the Wabash River (West Terre Haute, IN) and the Tampa Electric Integrated Gasification Combined Cycle (Lakeland, FL) clean coal technology demonstration programs. As joint cost shares with the USDOE, these facilities are intended to

\footnotetext{
${ }^{44}$ Antares Group, Inc., 1996, Repowering Applications and Markets for Biomass Fuel Integration and Augmentation, prepared for U.S. Department of Energy/National Renewable Energy Laboratory, July 22.
} 
demonstrate that coal gasification coupled with a CT/HRSG steam generation is ready for commercialization - i.e., turbines and other system components can be warranted for operation with the gasifier fuels, and plant availability is in the required range. Except for the control of alkalis in the gas stream to the gas turbine, gasification of biomass for power applications is well on the road to demonstrating similar capabilities.

As discussed previously, substitute CT/HRSG usually involves replacement of the existing boiler, fans, and stack with a combustion turbine and heat recovery steam generator. A basic configuration is shown in Exhibit 8.3-1. The existing steam turbine and related auxiliaries are retained and overhauled for use in the repowered combined cycle. In addition, there is usually a requirement for additional auxiliary equipment. Candidates for CT/HRSG typically operate at steam pressures in the $1300-1800$ psig range and steam temperatures of approximately 800 - 1100 degrees Fahrenheit. Since the capacity of the new gas turbine unit is usually twice that of the retained steam turbine, this type of repowering is accompanied by a large capacity increase. This necessarily requires that the transmission infrastructure connecting the overhauled plant with the utility grid be capable of handling a threefold increase in plant output. It should be noted that in some cases the costs of upgrading the transmission infrastructure (including potential new permits) may seriously impact the overall savings realized by the repowering project. Typically, boiler/generator units with capacities less than $150 \mathrm{MW}$ are considered optimum choices. However, it is not uncommon to use two or more smaller gas turbines with HRSGs in parallel to replace a larger existing boiler. This decision is based in large part on the specifics of an individual layout and the ability to sell the new capacity.

An attractive feature of this option is the reasonable cost of repowering relative to the incremental capacity increase. Estimates for repowering using a CT/HRSG with natural gas as the fuel range from $\$ 400$ to $\$ 700$ per $\mathrm{kW}$. These costs will be higher for biomass installations to cover the cost of gasification and gas cleanup steps. (For a high-pressure direct gasifier, these processes may add on the order of $\$ 1,000$ per $\mathrm{kW}$ to these costs. Of course, there are a variety of gasification processes currently in development and cost estimates will vary.) The primary challenge in installing a substitute CT/HRSG is matching the steam cycle parameters of the new installation to the requirements of the retained portion of the facility. For example, gas turbines are manufactured in discrete sizes and have specific thermal exhaust energies for steam generation. Steam turbines are often customized to meet the needs of individual plants. The degree to which these steam differences can be harmonized will influence the overall efficiency of the plant. In reality, it is very difficult to accomplish an exact match between these parameters. Even in cases where 
facilities are not perfectly matched, significant benefits are realized. As an example, despite a 21 percent derate of the steam turbines at PSE\&G's Bergen station, efficiency of the plant is expected to increase 16 points from 28 percent to 44 percent. In some configurations, efficiency may increase by as much as 30 points. These mismatches may also provide added benefits for BIGCC systems. Extra steam may replace or supplement flue gases to dry biomass feedstock.

Expected emissions reductions for repowering will vary from plant to plant and will depend greatly on the types of emissions controls currently in use, the type of fuel being consumed, and the repowering option chosen. As an example, plants currently using pulverized coal as a fuel will benefit greatly, while oilfired plants may see less of a reduction in emissions.

A substitute CT/HRSG repowering usually replaces the existing coal- or oil-fired boiler with a cleaner generation process. Other technologies, including the remaining two explored in this section, simply supplement existing boilers, leaving the emissions characteristics of the existing facilities virtually unchanged. Possible emissions reductions from current fuel operation are listed in Exhibit 8.3-2. In each case, the new fuel is assumed to be natural gas.

By the nature of the design, a CT/HRSG lends itself well to the needs of a cogeneration plant. Although configurations for accomplishing this vary, they usually entail extraction of the required process steam from the HRSG for re-direction to the appropriate application or "over the fence." The P\&P industry is one area of the biomass power market that may have potential for cogeneration and the sale of excess electricity or steam. In addition to using black liquor from the pulping process, many of these plants are already using biomass in the form of hog fuel in conventional boilers to supply on-site power and steam. If repowered, these facilities will generate heat and power more efficiently and may be able to generate power and steam for export. If excess steam/electricity were sold to a third party, (e.g., a local plant, utility, or IPP) the additional income would help pay for the investment.

\subsubsection{Parallel Power Cycles: Feedwater Heater Repowering}

Parallel cycles are attractive for biomass repowering for several reasons:

- The amount of feedwater heating from turbine exhaust can be varied over a wider range than extraction steamheating, allowing the system to better match available biomass resources.

- The system can provide a combination of primary fuel savings and incremental capacity.

- The add-on gas turbine topping cycle can be bypassed and fully isolated from the steam cycle for repairs and maintenance. This feature also reduces some of the risk for pioneer installations.

- Compared to substitute CT/HRSG, for a given plant this option requires a lower level of capital investment. 
There are a variety of design approaches for repowering using this option, and for some specific cases,

EXHIBIT 8.3-3

Feedwater Heater Repowering

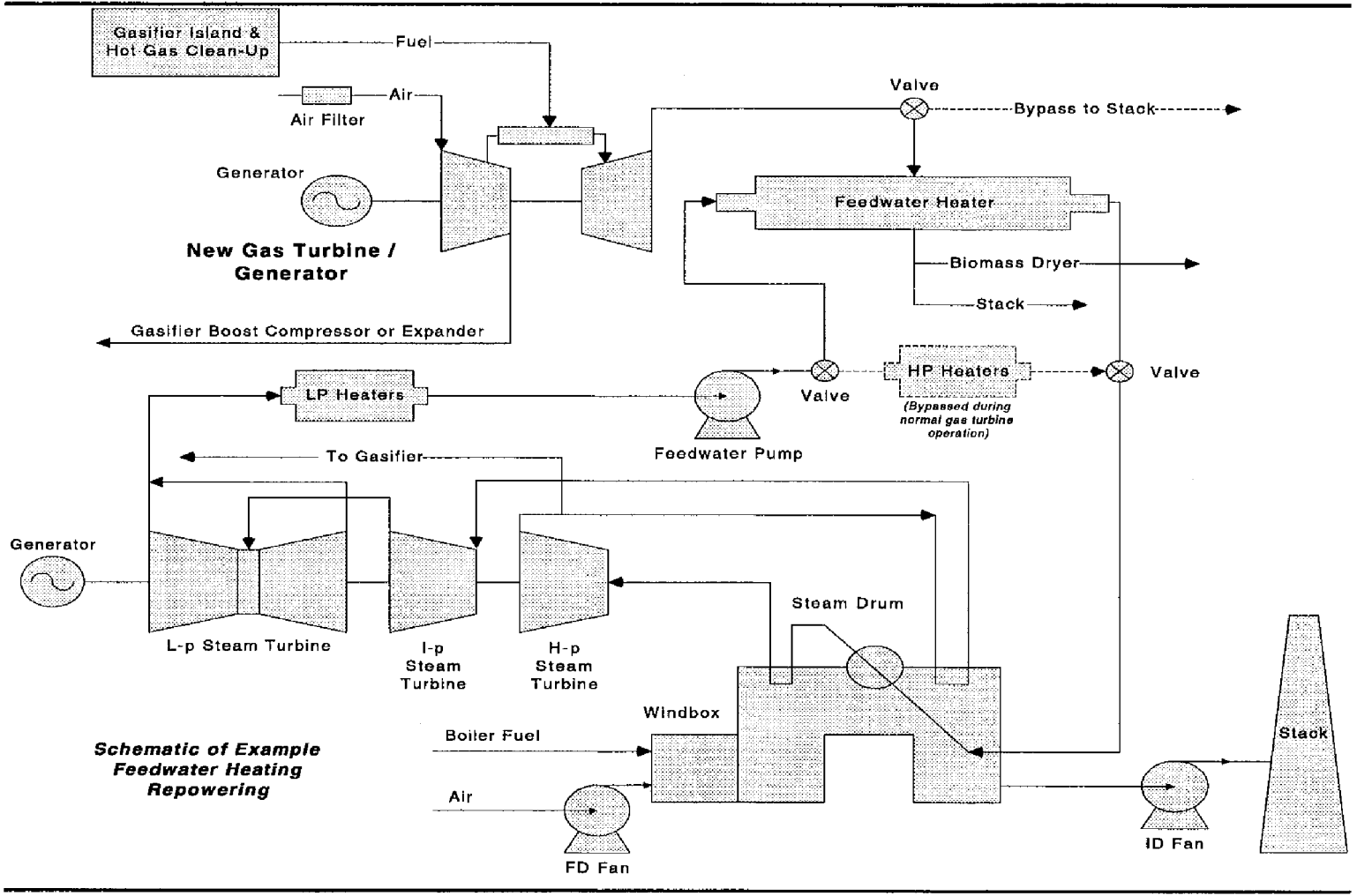

these configurations may provide the most cost effective generation investment. Facilities that have switched to a lower-cost fuel not as well suited to the existing boiler or boilers that have been derated because of air emissions regulations both provide opportunities to use the increased steam generation from parallel cycles.

A parallel cycle of particular interest is Feedwater Heater Repowering (FWHR). Feedwater heater repowering offers a less drastic power plant upgrade option than substitute CT/HRSG. For biomass installations, this helps lower the total capital investment and provides a good match to available biomass resources. However, capacity increases and heat rate reductions are smaller than those achieved using the substitute CT/HRSG option. Refer to Exhibit 8.3-3 for a possible schematic of one FWHR repowering arrangement.

The principle behind FWHR is straightforward. Feedwater for the existing boiler is heated by the exhaust of an added combustion turbine instead of by extracted steam from the existing steam cycle. This increases system performance in several ways. First, there is additional capacity created from the combustion turbine. Second, gas turbine exhaust heat can either displace a portion of the boiler primary fuel or increase steam flow to the steam turbine. The major constraint to this type of system will be the ability of upstream components (the steam turbine, condenser cooling systems) to handle the increased steam flow. In general, the more steam flow to the feedwater heating systems that is displaced by the combustion turbine exhaust, the more efficient the overall cycle is likely to be. However, there is the concern that the extra steam flow may cause back-end loading of the steam turbine. 
FWHR is probably best suited to larger facilities that can handle the additional steam flow. Typical efficiency improvements for feedwater heating topping cycles are in the 2-5 percent range. Capacity increases can be as high as 35 percent. Besides adding a combustion turbine, retrofits are usually limited to the feedwater heating systems and plant modifications are considered low compared to other options. Therefore, when using natural gas as fuel, capital costs are relatively low and range from about $\$ 100$ to $\$ 600$ per $\mathrm{kW}$. This makes FWHR a potentially less capital intensive repowering option. There are also several operational advantages that FWHR offers. It is possible to design this system to allow for independent operation of the gas turbine to generate power at reduced loads. The bypassed feedwater systems allow the plant to revert to pre-repowered conditions in the event of combustion turbine shutdown. It may also be possible to configure the system to allow for a hot standby. This arrangement might allow the combustion turbine to remain running at idle and using the turbine exhaust to keep feedwater temperatures up while the boiler is down. When the boiler is brought back on line, the time to reach full operational capacity may be reduced.

The non-intrusive and reversible nature of this configuration may make it an ideal choice for pioneering applications using biomass in the repowering market. Although it appears that this technology will be best suited for larger facilities where economies of scale can be employed, a first-generation biomass application may be more focused on reduced technical risk and successful implementation than on highly optimized performance.

High-efficiency aeroderivative gas turbines including advanced intercooled aeroderivative turbines could be a good match for this type of repowering. The highest feedwater temperatures required will usually be below $600^{\circ} \mathrm{F}$, a temperature that is well matched with the exhaust temperature of these turbines.

Additionally, many of the other problems associated with using aeroderivative turbines in other repowering options, such as flame stability, are not a concern in this application. Intercooled aeroderivatives may provide even greater advantages in cycling capability and reduced O\&M costs. This would tend to soften some of the cost penalties associated with using larger, less efficient industrial frame turbines.

Since the FWHR configuration does not require a change in primary fuel, there will usually not be any significant reductions in plant emissions. There has been some speculation that using this technology may allow the firing temperatures of the existing boiler to be lowered, thereby reducing $\mathrm{NO}_{\mathrm{x}}$ formation, but more work needs to be performed before any conclusions can be reached.

There is some potential for cogeneration with this configuration. Since the function of a boiler feedwater heater can be completely transferred to the gas turbine exhaust, the displaced steam can be directed to destinations other than the steam turbine. However, the amount of steam available through this process can vary with the plant layout, and overall efficiency can be greatly reduced.

This configuration allows for an upgrade in generation capability using a "green" technology without significant modification of existing power generation equipment. In other words, this repowering method would allow the power generation community to be more environmentally friendly (using biomass for a generation boost) at relatively low cost, without major overhaul or replacement of existing power generation infrastructure.

\subsubsection{Windbox Repowering}

Windbox repowering can be accomplished for small industrial or package boilers that do not use air preheating systems (Cold Windboxes) or for larger industrial or utility scale boilers that do (Hot Windboxes). Both windbox repowering options involve the addition of at least one topping cycle gas turbine to an 
existing steam generation cycle. Exhaust from the gas turbine is directed into the windbox of the existing boiler creating a combined cycle power plant (fully fired boiler or turbocharged boiler).

CT/HWBR is especially suited for repowering larger, newer oil and gas units (high gas velocities of the system do not lend it to use in coal- fired units). Further, this method provides good heat rate improvements and capacity increases while allowing reduced $\mathrm{NO}_{\mathrm{X}}$ emissions. Capital cost estimates range from $\$ 150 / \mathrm{kW}$ to $\$ 600 / \mathrm{kW}$, potentially making this type of repowering one of the least expensive options available (capital costs reflect the cost of using natural gas-powered turbine). Although not immensely popular in the U.S. market, CT/HWBR repowering has been implemented successfully in the Netherlands in a number of repowering projects. Some technical concerns, such as thermal differences between the water walls and windbox, and metallurgical issues with the burners themselves, must be addressed when considering this option. Additionally, modifications to the existing boiler and parts of the steam path may be extensive. Typical modifications would include removal of the existing air heater, the replacement of the existing windbox with a larger and higher-temperature windbox, installation of low $\mathrm{O}_{2}$ burners (flame stability is a concern since the gas turbine exhaust will have reduced $\mathrm{O}_{2}$ levels relative to ambient air), the addition of turbine exhaust duct work, and the installation of stack gas coolers to recover heat in the boiler flue gas.

EXHIBIT 8.3-4

Hot Windbox Repowering

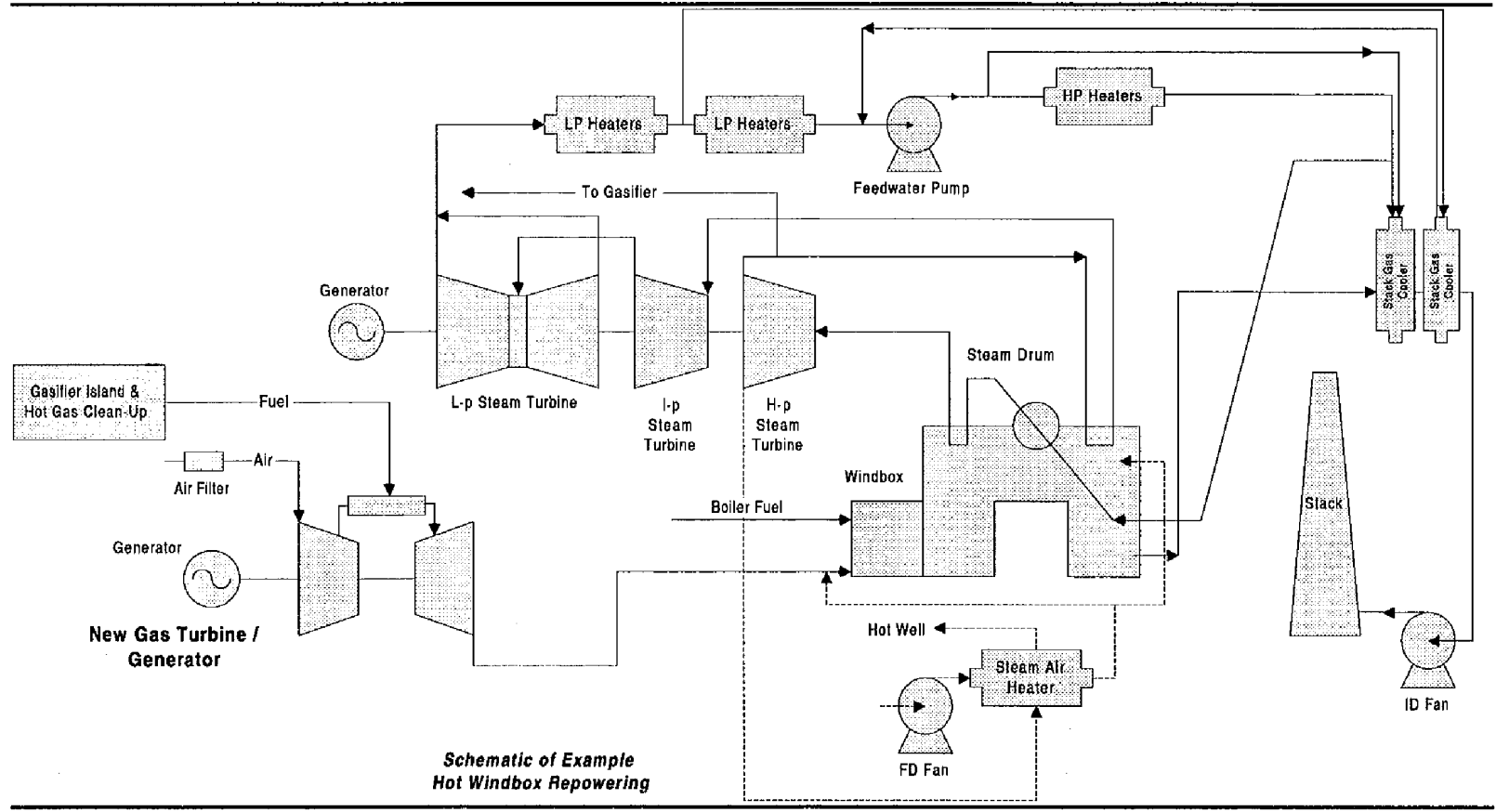

Cold windbox repowering will be an option in smaller industrial facilities currently using boilers without air pre-heating systems. Capital cost estimates for cold windbox repowering may be on the order of $\$ 600$ $\$ 800 / \mathrm{kW}$. Retrofitting the existing steam generation system for this option will require an examination of existing materials, fans burners, ductwork, dampers, flame safety systems, and air flow controllers.

\subsection{Gasification - Technology Review}

Converting plants to combined cycle operation using gas turbines and biomass as a feedstock presents many interesting challenges to technology and power project developers. Biomass gasification has 
emerged as promising strategy that could lead to high cycle efficiencies and economic viability for future power plants. This section briefly reviews a few gasification technologies which will provide a means for coupling biomass feedstocks and gas turbines.

\subsubsection{Biomass Integrated Gasification Combined Cycles (BIGCCs)}

The reliance of most repowering configurations on topping cycle gas turbines makes the development of biomass gas turbine technologies crucial to the future of biomass repowering. The primary goal of gasification technologies targeted for integration with gas turbines is to reliably and efficiently produce clean synthesis gas of a consistent quality.

Currently there are several biomass gasification processes under development. Among them are the highpressure, direct gasification system being developed by the Institute of Gas Technology (IGT), Battelle Columbus Laboratory's Low-Pressure indirectly heated gasifier, Studsvik's low-pressure direct air-blown gasification process, Lurgi low-pressure circulating fluidized-bed gasifier, and the Rheinbraun HighPressure, High-Pressure Temperature Winkler system.

A complete treatment of biomass gasification is beyond the scope of this report. However, we will examine the key features of three types of gasification systems. The three representative samples of the group are the IGT, Batelle, and Lurgi gasification systems. For example, one of the major differences among these gasifiers is how product gas from the gasification process is cleaned. For the high-pressure IGT gasifiers, a tar removal

EXHIBIT 8.4-1 Gasifier Specification Comparison

\begin{tabular}{|c|c|c|c|}
\hline $\begin{array}{l}\text { Gasifier } \\
\text { Specification }\end{array}$ & $\begin{array}{l}\text { High Press. } \\
\text { Direct } \\
\text { (IGT) }\end{array}$ & $\begin{array}{c}\text { Low Press. } \\
\text { Direct } \\
\text { (Lurgi) }\end{array}$ & $\begin{array}{l}\text { Low Press. } \\
\text { Indirect } \\
\text { (Batelle) }\end{array}$ \\
\hline Temperature & $830^{\circ} \mathrm{C}$ & $870^{\circ} \mathrm{C}$ & $826^{\circ} \mathrm{C}$ \\
\hline Pressure & $2.07 \mathrm{MPa}$ & $0.14 \mathrm{MPa}$ & $0.17 \mathrm{MPa}$ \\
\hline Btu/scf, Gas (LHV) & 115 & 129 & 354 \\
\hline Capital Cost $(\$ / \mathrm{kW})^{*}$ & 499 & 394 & 245 \\
\hline \multicolumn{4}{|c|}{$\begin{array}{l}\text { *Capital cost in } 1990 \text { dollars, does not include contingencies, engineering costs, or balance of plant } \\
\text { equipment costs. Source: NREL report, K.R. Craig and M.K. Mann, "Cost and Performance Analysis of } \\
\text { Biomass-based Integrated Gasification Combined Cycle Power Systems," revised } 1996\end{array}$} \\
\hline
\end{tabular}
system (employing either tar condensation or tar cracking via a catalyst), and gas cooling system to condense alkali species (by direct or indirect quench) are used before it enters a hot gas clean-up (HGCU) filter. The cleaned gas then enters the combustion chamber of the gas turbine at an appropriate pressure. Low pressure direct gasification also makes use of a tar cracker. However, product gas is then passed through a syngas cooler and bag filter unit. The gas is cooled further by being passed through a water scrubber and is then washed with a dilute sulfuric acid stream. The gas must then be compressed before entering the GT combustion chamber.

An indirect low pressure gasifier works in a similar fashion. The distinguishing characteristic of this design is that the heat required for gasification is supplied by sand that is circulated between the gasification vessel and the char combustor. The other systems described use separated char combustion and gasification vessels. Exhibit 8.4-1 outlines possible operating conditions of these gasifiers. 
Cost and the added complexity of biomass gasification systems relative to natural gas-based options continue to loom as hurdles for commercial acceptance of these technologies. As shown in Exhibit 8.4-1, the cost of the gasification, without the associated gas turbine, is significant. The higher investment cost and operating costs associated with using biomass and gas turbines relative to natural gas-fired systems will have to be amortized by using low-cost feedstocks. Consistently obtaining large quantities of quality biomass fuels is difficult and requires a detailed fuel supply plan. Provided that the appropriate fuels can be obtained, these systems should begin working their way into the commercial marketplace early in the next decade.

\subsubsection{Black Liquor Gasification Combined Cycles}

Black liquor gasification is a special type of biomass gasification technology. The technology is intended to be applied at mills producing wood pulp for use in paper and paper products. There are a number of different processes and these will be more thoroughly explored in chapter 9. For now, suffice it to say that in the chemical pulping process, black liquor is a mixture of lignin from the wood and inorganic chemicals. If concentrated through evaporation, black liquor can be combusted for the dual purpose of generating heat and recovering valuable pulping chemicals. Black liquor gasification accomplishes this through advanced gasification processes, while traditional chemical recovery is typically performed using special recovery boilers.

\subsection{Possible Opportunities to Use Biomass for Repowering}

Discussion to this point has centered on the technologies that will make repowering using biomass technically feasible. However, repowering a plant is foremost a business decision. Whether the goal is to reduce production costs, increase electrical/steam capacity or more fully integrate plant processes the intent is the same: improve the economic viability of the plant. The type of plant or industry is therefore key in examining possible biomass repowering opportunities.

\section{The Domestic Power Sector}

If a plant's primary purpose is to produce power, the decision to repower can be based almost entirely on the criteria outlined at the beginning of this chapter, technical feasibility, availability of low cost fuels, emissions benefits, et cetera. However, there are some specific situations when it may be especially attractive to repower using biomass. One example may be found in some of the marketing strategies being employed by power marketers in states with pilot retail wheeling programs. Industry observers have noticed that marketing strategies are focusing on price, local experience, and "green" energy. The push, either through government policy or customer preference, to generate more renewable power may offer generation companies the incentive to repower existing facilities with greener biomass technology. Options like FWHR that offer operational flexibility, relatively low retrofit costs, and moderate increases in capacity, may be excellent strategies to help power producers become greener without taking the more serious risks of greenfield development.

Other potential targets for biomass repowering may be existing, inefficient biomass-fired facilities. As an example, plants operating in California had been operating with efficiencies between 14 and 18 percent. The situation in California has been changing dramatically, but there are many wood-fired plants in the U.S. that can be considered for repowering. Repowering these plants can reduce production costs, provide increments of new capacity, and increase their efficiency. Like facilities in the wood products industry, these plants are already positioned to handle biomass in large quantities and are accustomed to dealing with the existing biomass supply infrastructure. To that end, one DOE-sponsored demonstration biomass power project is aiming at this market. Using technology licensed from BCL, industry partners and $\mathrm{DOE}$ are working together to repower McNeil Generating Station in Burlington, Vermont for BIGCC operation. 
If successful, the project will demonstrate the possibility for existing biomass facilities to become more competitive in a changing electricity market.

\section{The Domestic Industrial Cogeneration Sector}

For this discussion, the industrial sector is broken down into two subcategories: industrial facilities generating steam for on-site use but buying electricity, and cogenerators (generating both steam and electricity) that are seeking expanded steam/electricity capacity for use or sale.

Industrial Thermal Plants

"When one considers the cogeneration option, it is usually because you believe you might be able to generate electricity more cheaply than your local utility or because you perceive an opportunity to profit by selling the power that you generate. ${ }^{145}$ For biomass facilities, avoiding tipping fees or waste removal might lead to this belief. CWBR, described previously, may be one option for upgrading to cogeneration if strict technical criteria are met. However, assuming that some portion of the existing facility's electrical needs are met by the local utility, the following items are important:

- Will the repowering meet all of the modified plant's electricity needs, or must some additional power still be purchased from the utility? Similarly, if overcapacity will result, can the excess power be sold?

- Will the costs of producing new electricity/steam be below the utility's "best" price or are they just less than the current cost of purchasing electricity?

- For biomass facilities, are there any additional value added benefits to using biomass? - emission credits, avoidance of tipping fees, value-added production, et cetera.

The answers to these questions will depend on the behavior of the local utility. For example, the local utility may be willing to offer extremely competitive rates to an existing industrial customer to dissuade him from cogenerating or expanding existing electric generation capacity. Many states permit their utilities to charge rates below published tariffs in an attempt to defer cogeneration. This may adversely affect the economic viability of repowering these facilities, especially because of the initial high costs projected for BIGCC systems. Ultimately, repowering these facilities will depend on the economics of the alternatives. Provided that new electricity and/or steam can be economically used or sold, repowering will be a viable option.

\section{Industrial Cogeneration Plants}

There are many different biomass facilities that are already cogenerating. According to EIA ${ }^{46}$ approximately 76 percent of the U.S. biomass capacity is installed at cogeneration plants. This capacity comprises approximately 13 percent of the capacity installed at cogeneration plants as a whole (refer to Exhibit 8.5-1). A large percentage of biomass energy use is in pulp and paper mills as shown in Exhibit 8.5-2. Chapter 9 will explore more fully this particular sector and how black liquor gasification may play an important role in repowering this particular industry. Other biomass industries that are cogenerating are sugar mills, and saw mills.

\footnotetext{
${ }^{45}$ Speiwak, Scott A., and Larry Weiss, Cogeneration and Small Power Production Manual 4th Edition, Fairmont Press, 1994 , pg.3.

${ }^{46}$ Energy Information Administration, Annual Energy Outlook 1997, Table A17, December 1996, pg. 118.
} 
Making inroads against natural gas-based cogeneration industries ( 70 percent) will be difficult. However some 18 percent of cogeneration facilities are using coal. Repowering these facilities with biomass-based technologies may be possible provided the resource is available, and the facilities meet the technical and economic criteria outlined in this report.

Electric Capacity of Cogenerators (GW)

EIA Annual Energy Outlook 1997

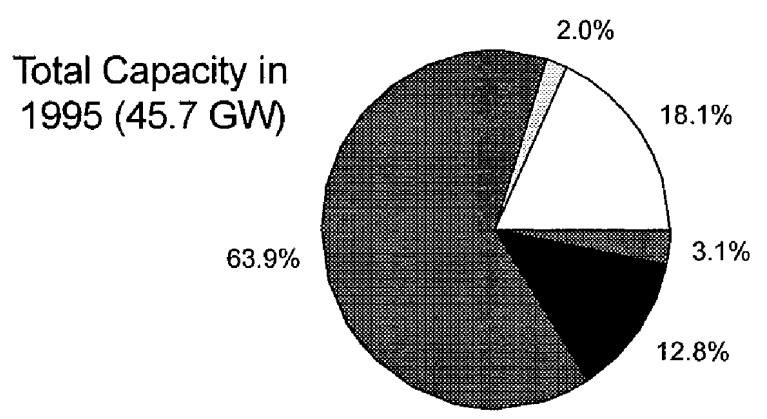

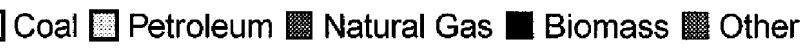

EXHIBIT 8.5-1

Electric Cogeneration Capacity

Industrial Biomass Enery Consumption

Total in $1994(1,670)$ Trillion Btus

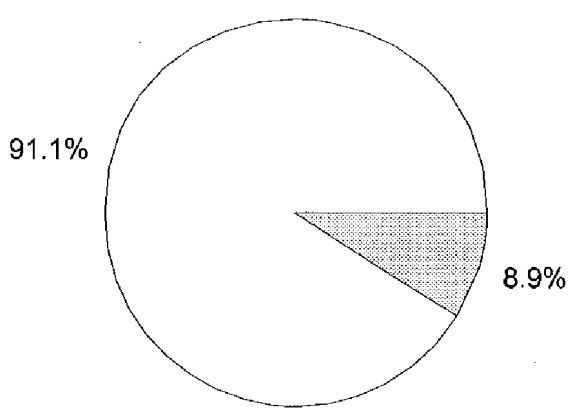

$\square$ Pulp \& Paper $\square$ Other

EXHIBIT 8.5-2

Industrial Biomass Energy Use 


\subsection{U.S. PULP AND PAPER INDUSTRY}

As noted in chapter 8, the pulp and paper industry is already an important part of the existing domestic biomass power generation market. Initiatives aimed at obtaining higher levels of energy self-sufficiency are also expected to make this industry an especially attractive market for advanced biomass power technologies.

\subsection{Characterization of the U.S. Pulp and Paper Industry \\ 9.1.1 Industry Growth and Capital Intensity}

The paper industry is among the leading manufacturing industries in the U.S. as measured by dollar value of its shipments and gross investment. In 1994, the pulp and paper industry included 547 mills in 42 states, which produced 82 million tons of paper and paperboard and 10 million tons of market pulp, representing 35 percent of the world's pulp production. ${ }^{47}$ Recently, the industry rebounded from a period of extremely slow growth in the early 1990s. By 1994, the demand for paper was expanding and exports were booming; domestic paper and paperboard consumption grew by 3.4 percent, and a strong revival in exports boosted industry production growth to 4.0 percent for the year. ${ }^{48}$ Specifically, since 1989 , exports accounted for 45 percent of total production growth.

Economic growth experienced by the emerging nations has led to a corresponding increase in demand for paper. The U.S. has been able to supply a significant portion of this demand. However, its competitive edge is being tested on several fronts:

- The paper industry is the most capital intensive industry in the U.S.; its investment requirements are more than twice the average of other domestic manufacturing industries-an average of $\$ 120,000$ of plant and equipment is invested for every industry employee. ${ }^{49}$

- The industry is trying to reach a paper recovery goal of 50 percent by 2000

- It spends approximately $\$ 1$ billion per year on environmental improvement and compliance

- Despite its movement towards energy self-sufficiency, it is the third largest industry measured by purchased energy in the U.S. (behind the chemicals and primary metals industries); and it is the fourth largest user of fossil fuels in the industrial sector. ${ }^{50}$

The industry's ability to maintain its competitive presence, therefore, will be shaped by several strategic challenges: 1) increased environmental spending to comply with air, water, and solid waste standards; 2) fiber supply, because public policy has made it more difficult and expensive to grow, manage, and convert trees into useful products; and 3) paper recovery, because although paper recycling is on the rise, the

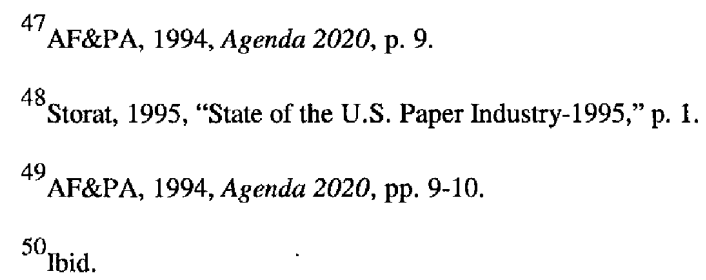


challenge is to secure adequate supplies of the right type of recovered fiber. ${ }^{51}$ To avoid relapsing into a recessionary period, the industry is interested in finding innovative ways to overcome these obstacles and sustain its dominant position in the world economy.

\subsubsection{Demand for Electricity and Heat}

The pulp and paper industry is the largest self-generator of electricity among the U.S. industries, meeting about 57 percent of its own electricity requirements. ${ }^{52}$ In 1994, this translated to approximately 67 billion $\mathrm{kWh}$ of the total 120 billion $\mathrm{kWh}$ required by the pulp and paper industry. ${ }^{53}$ This industry is well-suited for cogeneration for several reasons:

- Its processes require large amounts of heat and electricity.

- Large volumes of wood residues (biomass) and black liquor available on site as by-products of the pulp and paper process provide low-cost fuel inputs for steam and power generation purposes.

- If not used for power generation, wood residues and black liquor would present waste disposal problems.

As stated, the paper industry is one of the largest industrial consumers of energy in the U.S. According to the American Forest and Paper Association (AF\&PA), in 1995, the pulp, paper, and paperboard industry consumed 158,331 billion BTU of electricity. ${ }^{54}$ As shown in Table 9.1-1, the average paper mill is consuming 16 percent more electricity in 1991 than it did in 1988. However, although self-generation is playing a greater role, the mills are still purchasing a large amount of their power requirements.

In the future, cogeneration by the U.S. pulp and paper industry is projected to grow by 17 to 37 percent between 1995 and 2015, representing an increase in generating capacity of 1.7 to $3.6 \mathrm{GW}$ over the present levels. Total electricity generation is expected to increase 18 to 37 percent between 1995 and 2015 , to an additional output of 12.3 to 25.3 billion $\mathrm{kWh}$.

\footnotetext{
${ }^{51}$ Storat, 1995, "State of the U.S. Paper Industry-1995," pp. 3-5.

${ }^{52}$ Energy Information Administration, Manufacturing Consumption of Energy 1991, p. 124.

${ }^{53}$ Miller Freeman Inc., 1997 North American Pulp \& Paper Factbook, p. 60.

${ }^{54}$ AF\&PA, 1996, personal communication, October 28.
} 
EXHIBIT 9.1-1

U.S. Paper Mills - Energy Statistics

\begin{tabular}{|c|c|c|}
\hline & 1991 & 1988 \\
\hline Total Number of Paper Mills ${ }^{A}$ & 544 & 538 \\
\hline Net Electricity Demand (million $\mathrm{kWh})^{\mathrm{B}}$ & 61,054 & 51,951 \\
\hline $\begin{array}{l}\text { Average Net Electricity Demand per Paper Mill (million } \\
k W h)\end{array}$ & 112.2 & 96.6 \\
\hline Total On-site Generation (million $\mathrm{kWh}$ ) & 30,841 & 24,914 \\
\hline $\begin{array}{l}\text { Average On-Site Generation per Paper Mill (million } \\
k W h)\end{array}$ & 56.7 & 46.3 \\
\hline$\%$ of Net Electricity Demand Met by Self-Generation & $51 \%$ & $48 \%$ \\
\hline$\%$ of Exported Power Sold to Utilities & $94 \%$ & $78 \%$ \\
\hline $\begin{array}{l}\text { Price Paid for Purchased Electricity (c/kWh): } \\
\text { in Northeast U.S. } \\
\text { in Midwest U.S. } \\
\text { in Southern U.S. } \\
\text { in Western U.S. } \\
\text { AVERAGE }\end{array}$ & $\begin{array}{l}6.0 \\
3.7 \\
3.4 \\
2.8 \\
3.7\end{array}$ & $\begin{array}{c}\text { N.A. } \\
\text { N.A. } \\
\text { N.A. } \\
\text { N.A. } \\
\mathbf{3 . 7}\end{array}$ \\
\hline
\end{tabular}

$A=$ from PPI's International Fact and Price Book

$B=$ Net electricity demand $=$ purchases + transfers in + total on-site generation

- sales and/or transfers of electricity off-site

Source: DOE/EIA, 1994 \& 1991, Manufacturing Consumption of Energy

\subsubsection{The Importance of Biomass in the Pulp and Paper Industry}

Approximately eighty percent of the total U.S. biomass capacity can be found in the cogeneration practices of the wood and paper industries. As shown in Exhibits 9.1-2 \& 3, the industry is moving towards greater self-sufficiency by more effectively using on-site biomass residues. In 1991, biomass sources met fifty-five percent of the industry's energy needs, up from forty percent in 1988. Biomass (including spent liquor) is projected to be the fastest growing source of fuel for cogeneration in the U.S. pulp and paper industry. 
EXHIBIT 9.1-2

P\&P Industry Energy

Consumption by Source (1972)

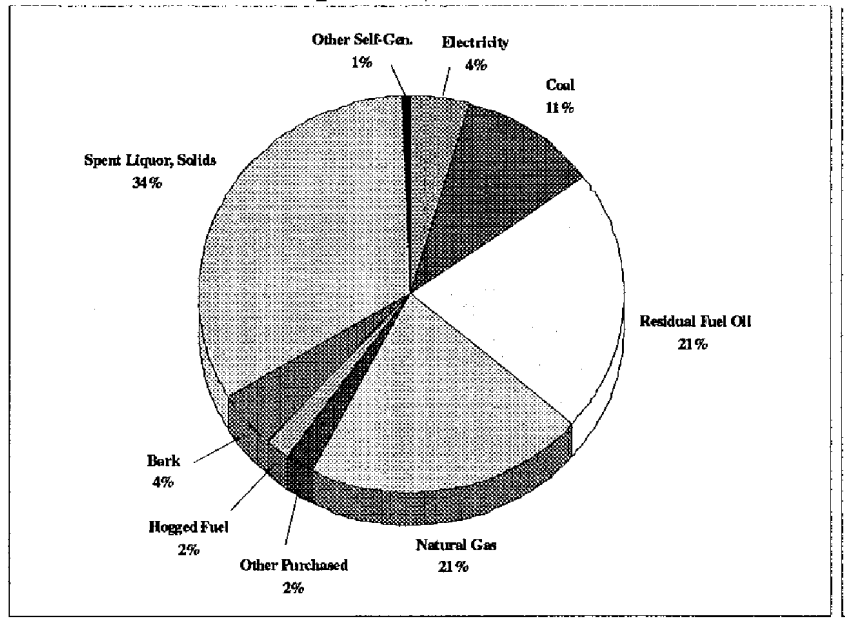

EXHIBIT 9.1-3

P\&P Industry Energy

Consumption by Source (1994)

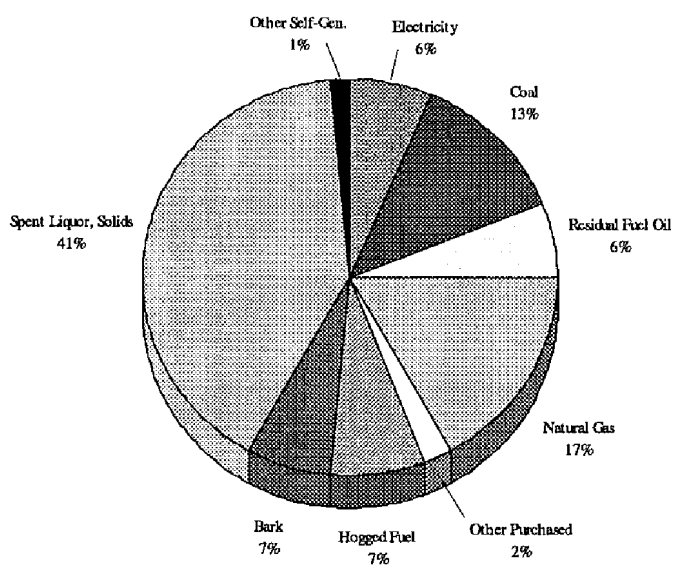

As this industry moves towards even higher levels of energy self-sufficiency, extracting the maximum possible value out of biomass resources will continue to be an important strategy.

\subsection{Pulp \& Paper Initiatives Toward Energy Self-Sufficiency}

To remain economically competitive, the U.S. pulp and paper industry will continue to utilize low-cost fuel and energy efficient technologies. Where possible, mills can become less dependent on fossil fuels and meet more of their internal needs by efficiently utilizing self-generated biomass and black liquor fuels. The move towards increased energy self-sufficiency stems from several factors:

- Increasing electrification at pulp and paper mills. Added environmental controls, manufacturing process changes, and limitations of on-site cogeneration technologies are driving up their electricity-to-heat demand ratios and increasing their dependence on purchased electricity.

- Increasing recycled content in the fiber furnished to mills is making less biomass available for energy use.

- Industry-wide concern for improving environmental performance.

- Aging fleet of recovery and biomass boilers will require major capital investments.

- Uncertainty regarding the ultimate impact on electricity prices due to restructuring of the electricity industry.

- Perpetual uncertainty regarding future costs of purchased fossil fuels.

Examples of the industry's efforts include: researching ways to improve the kraft chemical recovery process by using black liquor gasification technology; improved combined-cycle and cogeneration applications; and energy efficiency in wood and paper drying (the largest energy requirement in the pare was in which the industry is improving energy utilization and 
production technologies and extracting the maximum energy from its waste streams.

\subsection{Black Liquor Gasification Combined Cycles (BLGCC)}

Black liquor is the byproduct of the most common pulping process in the United States. The kraft pulping process represents 68 percent of domestic pulping capacity. It is a mixture of organic residues and spent pulping chemicals in solution. In modern Kraft mills, a recovery boiler (Tomlinson Boiler) is the heart of the process of recovering both energy and pulping chemicals for the liquor. This recovery is a critical element in the economics of production of kraft pulp for paper making. To provide the reader with some perspective on the importance that black liquor gasification technology could have to the pulp and paper industry, a brief description of the Kraft recovery process is provided below.

\subsubsection{The Kraft Chemical Pulping and Recovery Process}

Exhibit 9.3-1 depicts the kraft chemical pulping and recovery process. In the chemical pulping process wood chips are combined with fresh chemicals (e.g., white liquor in the kraft process) under elevated pressures and temperatures in digesters. White liquor is a chemical solution containing sodium hydroxide $(\mathrm{NaOH})$ and sodium sulfide $\left(\mathrm{Na}_{2} \mathrm{~S}\right)$. It is characterized by its "sulfidity," which is a measure of the amount of active alkali that is present as $\mathrm{Na}_{2} \mathrm{~S}^{56}$ The feedstock delignifies and the chemical/pulp combination is discharged to a blow tank where fiber separation and mixing occurs. Large amounts of heat and volatile compounds are released from the blow tank and provide a heat source for raising steam and auxiliary fuels, respectively. The slurry is screened for knots which fail to delignify and is washed to separate the pulp from spent chemicals (black liquor). The pulp can then be stored, shipped, or immediately used to produce paper while the spent chemicals enter a recovery process.

Chemical and energy recovery components of the process provide significant reductions of operating costs and are vital to the economics of the kraft mill. The kraft chemical recovery system is a process in which inorganic compounds from spent pulping chemicals (black liquor) are recovered and regenerated for use. Exhibit 9.3-1 also shows the kraft chemical recovery process. In addition to recycled inorganic chemicals, the process generates useful heat from the combustion of organics separated from the wood (e.g., extractive, lignin, and some carbohydrates). This energy is utilized to produce steam for electricity generation and process-related heating requirements.

\footnotetext{
${ }^{55}$ AF\&PA, 1994, Agenda 2020, p. 18.

${ }^{56}$ Larson, E. D., N. Berglin, S. Consonni, and T. Kreutz, 1996, Advanced Technologies for Biomass-Energy Utilization in the Pulp and Paper Industry, report to the U.S. Dept. of Energy, Princeton, NJ, Dec.
} 
EXHIBIT 9.3-1

Kraft Chemical Recovery System

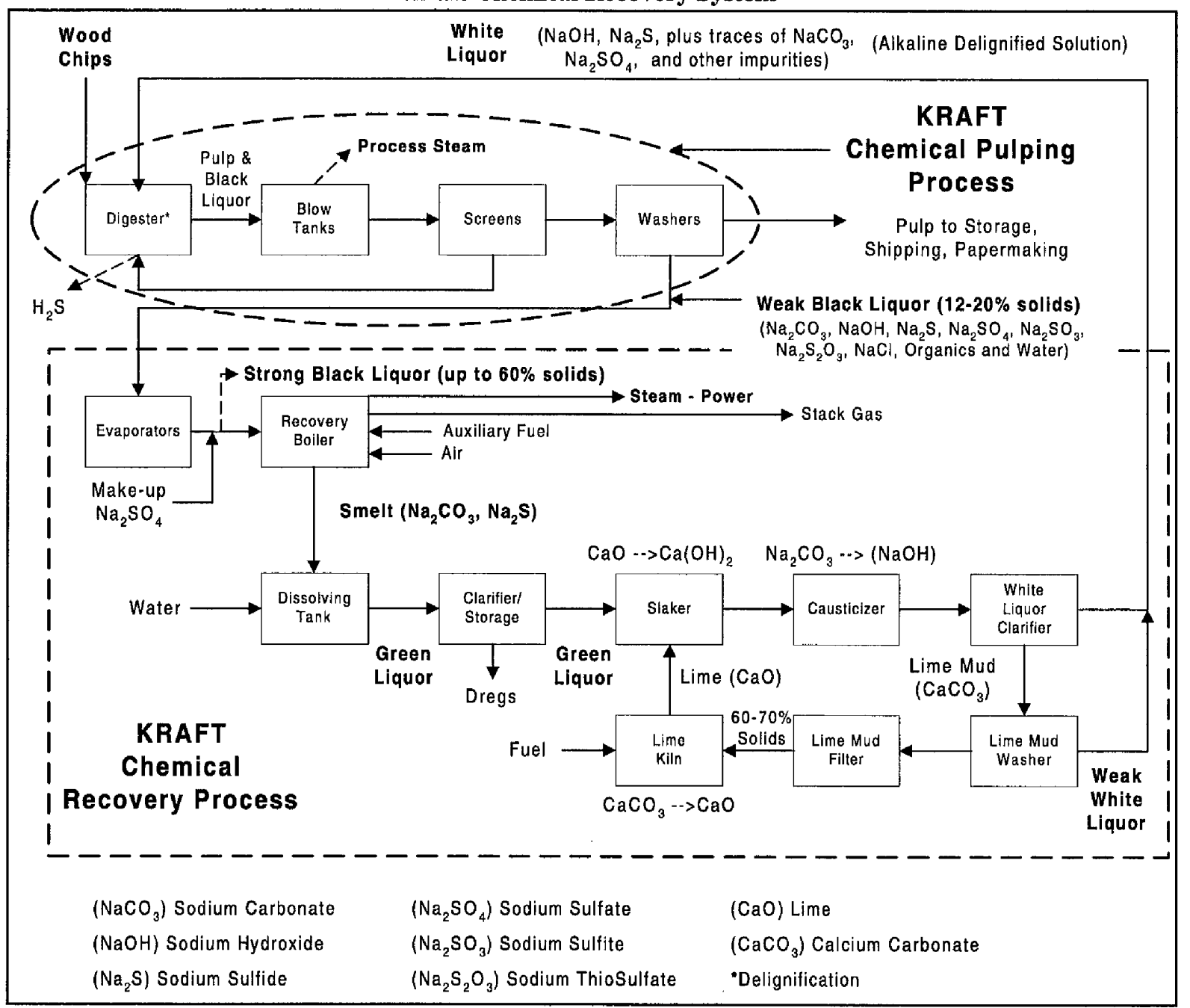

Before inorganic chemicals are recovered and heat is generated from the combustion of black liquor, water is evaporated from the spent chemicals to improve combustion efficiency. As water is removed, the solids content of the black liquor increases (the strength, or solids content, of the black liquor is conventionally expressed in percent overall - dissolved and suspended - solids content). Once concentrated to about 65 percent overall solids, the black liquor is burned in a boiler designed to capture the spent inorganic pulping compounds (or, alternatively, sent to a black liquor gasifier). The conventional arrangement of steam and power generation equipment at a pulp mill is shown in Exhibit 9.3-2. As the mixture is sprayed into the furnace of the boiler, water evaporates, leaving behind concentrated char and inorganic matter. Char combustion occurs partially in suspension and partially on a char bed at the bottom of the furnace. The lower portion of the char bed, consisting mostly of inorganic materials, is maintained in a reducing atmosphere. Such an environment allows the conversion of $\mathrm{NaOH}$ to $\mathrm{Na}_{2} \mathrm{CO}_{3}$, and the conversion of $\mathrm{Na}_{2} \mathrm{SO}_{4}$ to $\mathrm{Na}_{2} \mathrm{~S}$. The sulfur and sodium-based inorganic materials leave as molten slag referred to as smelt. To support char burnout, secondary fuels are fired in the recovery boiler. To maintain the desired chemical composition of the smelt, fuels which have little or no ash (e.g., natural gas, light fuel oils) are typically used as auxiliary fuels. 
EXHIBIT 9.3-2

Conventional Pulp Mill Steam and Power Generation System Diagram

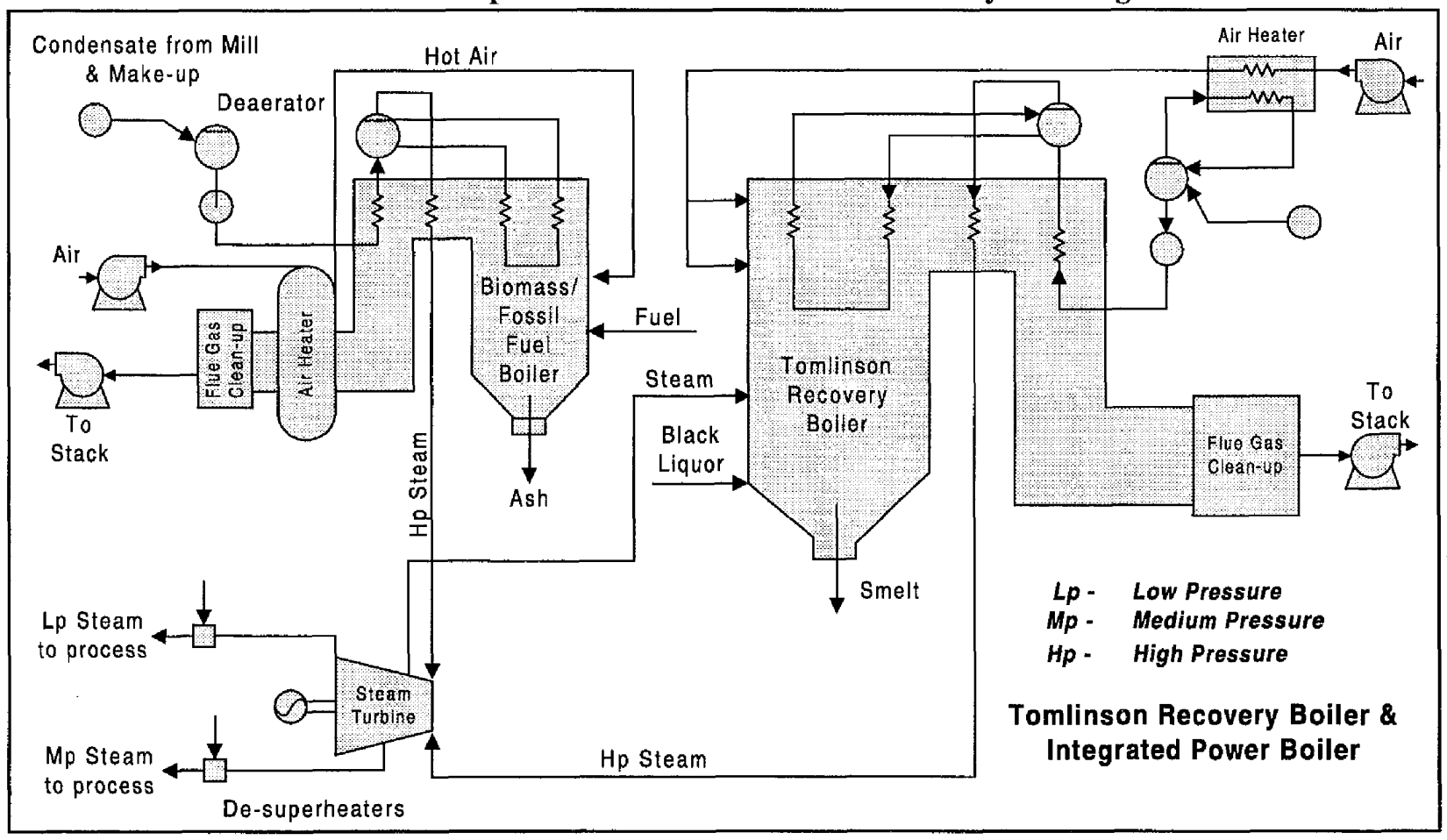

The smelt removed from the bottom of the recovery boiler furnace is immediately cooled and dissolved in a tank of water. The resulting mixture is referred to as green liquor. In order to regenerate sodium hydroxide, the green liquor undergoes a causticizing process. After sedimentation to remove foreign material and unburned char, the green liquor is mixed with lime $(\mathrm{CaO})$ in a slaker, allowed to react in a causticizer, and the $\mathrm{Na}_{2} \mathrm{CO}_{3}$ is converted to the required $\mathrm{NaOH}$. Furthermore, the lime is converted to a caustic $\left(\mathrm{CaCO}_{3}\right)$ referred to as "lime mud." With these chemical reactions the green liquor is converted to white liquor and, after clarification, is recycled to the digesters to further delignify fresh feedstocks. Although the above causticizing process results in regeneration of spent pulping chemicals, lime is consumed. With the addition of heat, the lime can be regenerated from the lime mud in the lime kiln. Prior to heat transfer, the lime mud is washed to remove alkalis which would otherwise cause slagging in the heat exchanger. After washing, the lime mud is dried, heated, and converted to $\mathrm{CaO}$ in a lime kiln--a direct contact heat exchanger with hot flue gases supplying the heat source. Flue gases are generally generated from combustion of natural gas or oil, although coal and biomass have been used. Thus the kiln can be considered a second combustion chamber (in addition to the recovery boiler) requiring a fuel other than black liquor.

Black liquor gasification technologies, when integrated with other process equipment in a pulp mill, must be capable of reliably performing all of the above functions as well or better than the existing boiler-based chemical recovery system. A key element of early commercial-scale gasification projects will be to demonstrate the capability of gasification systems to perform each of the dual functions of chemical recovery and power generation better than the existing systems. 


\subsubsection{Black Liquor Gasification}

Black liquor gasification replaces one step of the conventional kraft recovery process with two steps as shown in Exhibit 9.3-3. Rather than being burned directly in the recovery furnace, the black liquor is gasified in a reactor and the product gas is then cleaned and burned for steam and power generation. Both approaches recover pulping chemicals and energy from the spent pulping liquor.

Black liquor gasification technology is a variant on existing biomass and coal gasification technologies that are now entering the market in large-scale demonstration and commercial projects worldwide. These

EXHIBIT 9.3-3

Conventional Recovery Boiler System vs. Gasification-based Recovery System

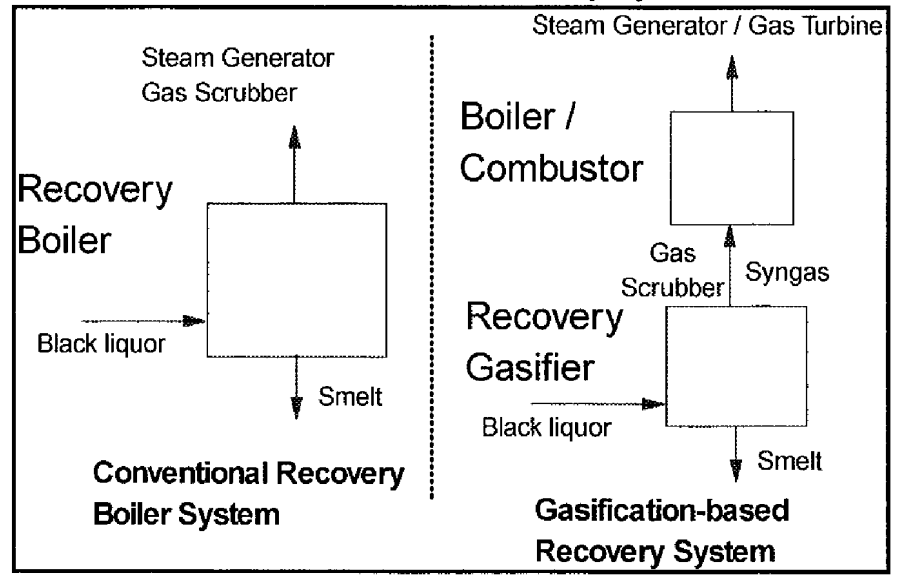
technologies are permitting biomass and other solid fuels to be used in high efficiency gas turbine combined-cycle generation systems that could replace many solid fueled boilers as a more competitive and environmentally acceptable system. As a gasification feedstock, black liquor presents unique problems and opportunities. The gasification process must meet dual process objectives: 1) generation of a low-Btu fuel gas capable of firing commercially available power and steam generation equipment, and 2) separation and recovery of the inorganic chemicals used in the pulping process. The second objective adds complexity to the gasifier design. At the same time, gasification processes offer some special advantages to the recovery process. Possible advantages of the black liquor gasification process over conventional chemical recovery systems are discussed in section 9.3.4.

The major challenges facing black liquor gasification technologies for combined-cycle operation are: 1) hot gas clean-up to produce gas sufficiently clean to be used in a gas turbine, and 2) integration of the technology with the pulping process. The first problem has been a persistent issue for all solid gasification feedstocks. The coal and biomass gasification technologies have begun to solve the gas clean-up problem, and although the systems for black liquor will be unique, a number of potential solutions are being developed and tested. The more complex design issue is that of integration with the pulp mill in a way that provides process enhancements. Several demonstration projects now underway should provide the evidence as to whether the gasification process will meet any or all of the expected benefits listed above.

Many of the companies interested in development of gasification technology have been monitoring the industry interest in the potential of the black liquor gasification/recovery processes. Four have active development programs (Kvaerner, ABB, MTCI and Noell) and one has just completed installation and startup of a 360-ton-per-day (tpd) unit at Weyerhaeuser's New Bern facility. The Kvaerner Chemrec unit is being used to boost pulping capacity at New Bern. This is potentially the best market for introduction of this new technology. The risks are lower (downtime for the gasifier does not bring mill operation to a halt) and the capital cost is more manageable while the cost benefits to the mill are potentially significant. 
The black liquor gasification processes currently under development and discussed below can be classified into the following three types: ${ }^{.7}$

1) Partial combustion in short-residence-time entrained-flow combustors (Kvaerner, Noell).

2) Partial combustion in long-residence-time fluidized beds (ABB).

3) Steam gasification in indirect heated fluidized beds (MTCI).

Each offers inherent advantages and disadvantages relative to the others. For this report, only the Kvaerner/CHEMREC process is reviewed since it is currently the closest to commercialization. Results from the initial testing of the other technologies indicate that there are differences in performance between systems regarding the relative amounts of steam and electricity produced by each. It is also expected that there will be different trade-offs between cost and performance among the technologies. Due to these differences and other potential process-related benefits, each technology may find its niche in the industry, depending on the process requirements for various types of mills operating under different economic circumstances.

\section{Kvaerner/CHEMREC Air-Blown, Direct Black Liquor Gasification}

Kvaerner Pulping's CHEMREC process uses a refractory-lined entrained-flow reactor and includes an integrated quench dissolver. Both atmospheric and pressurized systems have been developed. The general pressurized process is shown in Exhibit 9.3-4..$^{58}$

In the atmospheric process, product or auxiliary gas is used to heat the gasifier supply air. The air is heated to about $950^{\circ} \mathrm{F}$ either directly using a direct-fired heater or indirectly using a heat exchanger. A fine spray of concentrated black liquor is gasified in the reactor by exposure to the heated air in a reducing environment. The $1,750^{\circ} \mathrm{F}$ reactor operating temperature is above the inorganic smelt melting point, so smelt drops are formed in addition to the product gas. The smelt drops are mainly sodium carbonate $\left(\mathrm{Na}_{2} \mathrm{CO}_{3}\right)$ and sodium sulfide $\left(\mathrm{Na}_{2} \mathrm{~S}\right)$. Some of the smelt drops hit the reactor wall and form a thin liquid film which flows to the outlet of the reactor, while the remainder is entrained in the product fuel gas. The fuel gas and entrained smelt are instantly cooled by direct contact with green liquor in the quench dissolver. The smelt, along with a majority of the $\mathrm{H}_{2} \mathrm{~S}$ in the product gas, is absorbed by the green liquor and forms raw green liquor that is later recausticized in the mill's existing caustic plant. Next, the quenched product gas is further cooled by direct contact with a water solution in a venturi scrubber which removes particulates from the gas. Finally, the hydrogen sulfide $\left(\mathrm{H}_{2} \mathrm{~S}\right)$ scrubbers remove the remaining sulfur. In the atmospheric process, the product gas leaving the scrubbers contains about 10 percent moisture and is 105 to $125^{\circ} \mathrm{F}$. Heating values of the product fuel gas are about 75 to $95 \mathrm{Btu} / \mathrm{scf}$, depending on black liquor composition and the amount of air supplied. The atmospheric process yields fuel gas suitable for burning in a power boiler to generate steam.

The CHEMREC process was the first black liquor gasification system in commercial operation. An atmospheric pressure process has been operating as an incremental capacity addition at the Frovifors mill

\footnotetext{
${ }^{57}$ Grace, Thomas M. and William M. Timmer, 1995, “A Comparison of Alternative Black Liquor Recover Technologies," 1995 International Chemical Recovery Conference Proceedings, TAPPI, Atlanta, GA, pp. 269-271.

${ }^{58}$ Larson, Eric D., Niklas Berglin, and Stefano Consonni, 1997, "Black Liquor Gasifier/Gas Turbine Cogeneration," The 42nd ASME Gas Turbine and Aeroengine Congress, Exposition, and Users Symposium, Orlando, FL, June 2-5.
} 


\section{EXHIBIT 9.3-4}

Kvaerner/CHEMREC High-Temperature, Air-Blown Gasification Combined-Cycle System Diagram

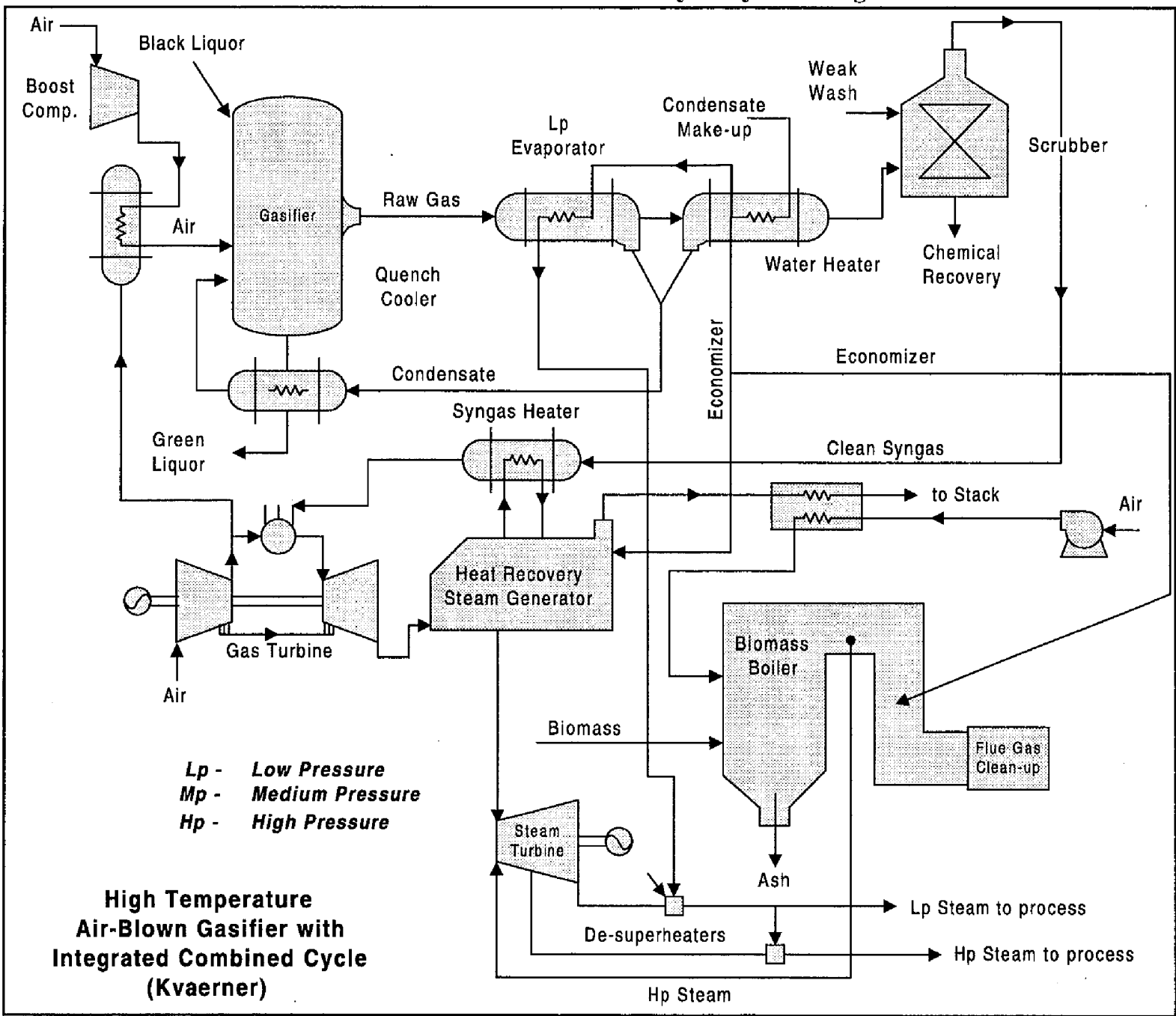

in Sweden since August 1991.59 The unit is capable of processing 80 tpd of black liquor solids and the product gas is burned in a power boiler to generate steam. After early refractory maintenance problems were solved, the unit has operated well. The atmospheric process is marketed as an incremental capacity expansion and is commercially available through Kvaerner Pulping. The system is capable of processing 250 tpd of black liquor solids.

A pressurized unit capable of producing fuel gas for use in a gas-fired turbine--and, therefore, in the more efficient combined-cycle power generation arrangement--began operating at the Skoghall mill near Karlstadt, Sweden in early 1994 . The system has a more extensive gas cleaning system than the original in Frovifors and has a capacity of 50 to 100 tpd of black liquor solids. ${ }^{60}$ The pressurized system offers

\footnotetext{
${ }^{59}$ Harrison, Andy, 1993, “Frovifors Mill Installs New Recovery Technology to De-bottleneck Fiberline," Pulp \& Paper, Dec., p. 30.

${ }^{60}$ Finchem, K.J., 1995, "Black Liquor Gasification Research Yields Recovery Options for Future," Pulp \& Paper, November.
} 
improved energy efficiency because most of the quench heat can be captured as low-pressure steam rather than hot water. The reclaimed heat can be used for process needs and feedwater heating.

More recently (August 1996), the first commercial black liquor gasification plant in North America was completed at the Weyerhaeuser plant in New Bern, North Carolina. It is similar to the CHEMREC unit in Frovifors but four times larger. It will be capable of processing 360 tpd of dry solids and was added as an incremental capacity expansion for the existing recovery plant. Operation of this plant will provide valuable information regarding the practical applicability of gasification technologies in the U.S. pulp and paper industry.

\subsubsection{Cost Comparisons}

Since no full-scale integrated black liquor gasification combined-cycle (BLGCC) plants have been built yet, and some components of the black liquor gasification technologies suitable for combined-cycle operation are still in the development stages (gas clean-up systems, etc.), the costs for these systems are still speculative. Fortunately, similar systems for coal and biomass gasification with integrated combinedcycle operation have been installed and are now operating. Several others are in the construction and planning stages. The costs of the black liquor systems can be related to those from coal and biomass for similarly sized plants.

Excluding the auxiliary power boiler and power generation systems that would also be needed for a greenfield plant, a black liquor gasification system is expected to cost about the same as a conventional recovery boiler (unless major process-related advantages such as direct-causticization are proven and shown to offer economic advantages). To fully take advantage of the benefits offered by gasification, the power generation system should be a combined-cycle arrangement. This will require the installation of a gas turbine, heat recovery steam generator, and steam turbine. A conventional system only requires a steam turbine. All costs included (recovery system, auxiliary boiler, power generation equipment), the gasification system with combined-cycle power generation will be about 30 percent more expensive than the conventional system. This is illustrated in Exhibits 4-1 for two pulp mill sizes, 1100 and 2200 air dry tons of pulp per day (adtpd). The gasification-based system, however, will be capable of producing about 2 to 2.5 times more electricity for essentially the same fuel input. ${ }^{61}$ Hence, per megawatt (MW) of electricity generation capability, the gasification systems are about 40 percent cheaper than the conventional systems.

\footnotetext{
${ }^{61}$ In comparison to a conventional recovery boiler system, slightly more fuel (wood chips, natural gas, coal, or oil) may be required in the auxiliary boiler in a combined-cycle gasification system in order to meet process steam requirements. This amount of additional fuel has been neglected in this analysis. The additional auxiliary fuel required for the gasification will be small relative to the added power generation benefits provided by the gasification system in suitable applications.
} 
EXHIBIT 9.3-5

Cost Comparisons for Conventional and Gasification-based Black Liquor Recovery Systems

\begin{tabular}{|c|c|c|c|c|c|}
\hline \multirow[b]{2}{*}{ System Description } & \multirow{2}{*}{$\begin{array}{c}\text { Pulp } \\
\text { Plant } \\
\text { Capacity, } \\
\text { adtpd }\end{array}$} & \multirow{2}{*}{$\begin{array}{c}\text { Black } \\
\text { Liquor } \\
\text { Capacity, } \\
\text { tpd ds }\end{array}$} & \multicolumn{2}{|c|}{ System Capital Costs, } & \multirow{2}{*}{$\begin{array}{c}\text { Total Power } \\
\text { Generation, } \\
\text { MW }\end{array}$} \\
\hline & & & $\$ /$ tpd ds & $\$ / k W($ tot $)$ & \\
\hline \multicolumn{6}{|c|}{ Gasification Systems } \\
\hline Combined Cycle Gasification & 1,100 & 1,914 & 39,390 & 1,450 & 52 \\
\hline Combined Cycle Gasification & 2,200 & 3,828 & 34,831 & 1,282 & 104 \\
\hline \multicolumn{6}{|c|}{ Conventional Recovery Boiler Systems } \\
\hline Tomlinson, ST & 1,100 & 1,914 & 30,701 & 2,026 & 29 \\
\hline Tomlinson, ST & 2,200 & 3,828 & 27,148 & 1,792 & 58 \\
\hline
\end{tabular}

\subsubsection{Effect of Gasification Technologies on the Pulp and Paper Operations}

Since quality pulp production (not electricity generation) is the primary goal of pulp mills, process-related benefits aside from increased energy efficiency will weigh very heavily in the decision-making process when considering whether to install conventional recovery equipment or a gasification system. Demonstration of process-related benefits will therefore be key to the future adoption of black liquor gasification systems.

Possible advantages of the black liquor gasification process over conventional chemical recovery systems include: $:^{62,63,64}$

- Lower capital investment per ton of dry solids

- More compact construction

- Higher cogeneration efficiency via combined cycle power generation

- Reduced risk of smelt water explosions

- $\quad$ Reduced smelt build-up

- Improved process control

- Maintenance of a more even load on the recovery boiler (for capacity expansion options)

- Elimination of the auxiliary fuel requirements for the lime kiln

- $\quad$ Reduced requirement for re-causticizing system capacity

- Potential for improved process flexibility through the capability to produce white liquors with differing degrees of sulfidity, or "split sulfidity"

While proposed benefits are important for consideration, observed advantages over conventional systems are much more meaningful. It will be a critical goal of early full-scale gasification projects to demonstrate

\footnotetext{
${ }^{62}$ Stigsson, Lars, 1989, “A New Concept for Kraft Recovery," 1989 International Chemical Recovery Conference Proceedings, TAPPI, Atlanta, GA, pp. 191-194.

${ }^{63}$ Harrison, Andy, 1993, op cit., pp. 30-32.

${ }^{64}$ Larson, Eric D. and Delmar Raymond, 1997, op cit.
} 
advantages over conventional technologies while convincingly alleviating concerns about possible negative impacts and potential problems. Demonstration of how gasification systems will operate when fully integrated into a mill's process operations, and of the resulting economic and process-related benefits, will be crucial to the acceptance of gasification by the pulp and paper industry. If these things can be demonstrated successfully, black liquor gasification, in combination will biomass (wood residues) gasification, will become the standard system for chemical recovery and power generation in the future pulp and paper industry. This will result in a tremendous increase in the industry's ability to produce electricity, not only to serve its own needs, but for sale to the exterior grid. By displacing electricity generated by non-renewable fossil fuels, the added power generation from the existing black liquor and biomass residue fuel supplies in the pulp and paper industry will greatly reduce acid rain and greenhouse gas emissions associated with the displaced fossil fuels. 


\subsection{EMERGING TECHNOLOGIES}

The technologies outlined in this chapter represent a few of the innovative distributed biomass power generation configurations being developed. There are many other possibilities, including diesel engines using producer gas, which has already been field tested in developing counties like India. However, this particular technology and many others have low cycle efficiencies or suffer from other complications (in this example 15-35 percent of the total fuel requirement must still met by petroleum diesel fuel) that may inhibit their potential for expanding into widespread commercial use.

Four technologies which have received considerable attention by biomass technology developers and other biomass power experts are Stirling Engines (using biomass gasification), Direct-fired biomass combustion turbines, Biomass Synthesis Gas Fuel Cells, and Biomass Integrated Gasification Cycles.

\subsection{Stirling Engines via Biomass Gasification}

Stirling engines are under development for different applications and sizes. Currently two types of engines are being investigated, kinematic and free-piston. In general, Stirling engines enjoy good efficiencies (even at part loads) and a high degree of fuel flexibility. The environmental benefits of these engines including reduced noise, exhaust emissions, and heat rejection, improve siting flexibility and may make these systems suitable for a variety of distributed generation applications. Initially, these systems may find their niche competing with gasoline- and diesel-fired generation.

In addition to these characteristics, both types of engines are applicable for small (less than $100 \mathrm{kw}$ ) distributed generation applications, thus, Stirling engines may be ideal for powering small villages or groups of villages that do not require extensive transmission and distribution infrastructure. If

EXHIBIT 10.1.2 Sunpower Inc. Biomass Stirling Engine

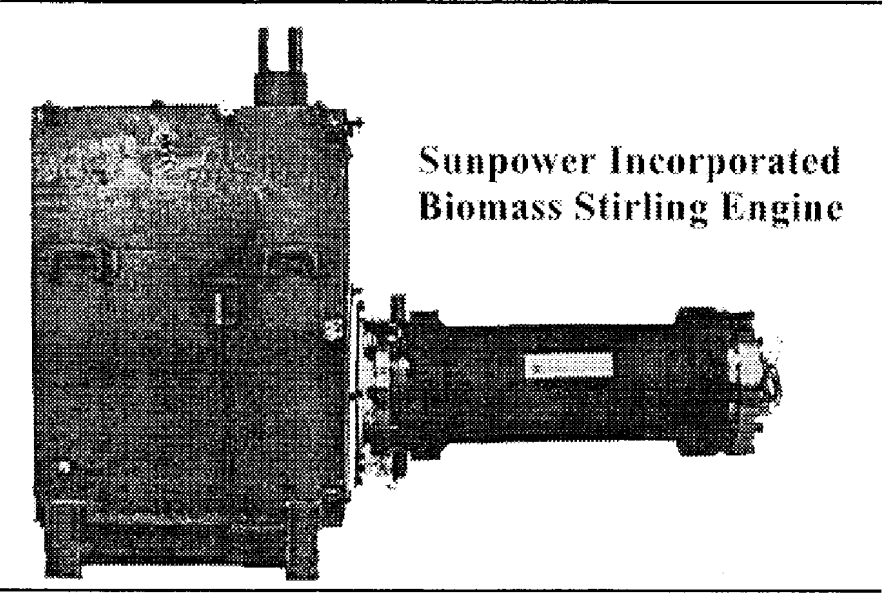

manufactured inexpensively, these engines may also provide an economic means of grid stabilization for villages that already have power. Refer to Exhibit 10.1-1 and 2 for examples of biomass powered Stirling engines.

\subsection{Direct-Fired Combustion Turbines}

Direct-fired combustion turbine systems, such as the ones being tested by BIOTEN at Red Boiling Springs, Tennessee, attempt to combine the operational efficiency and reliability of combustion turbines with biomass-derived fuels without a separate gasification step. Initial development of direct-fired combustion turbines have been plagued by technical problems including turbine blade fouling, fuel 
feeding and drying, high $\mathrm{NO}_{\mathrm{x}}$ emissions, system availability, and concerns about overall system safety. Of perhaps greatest concern is the limited number of acceptable biomass fuels. Currently, much of the research data available on these systems are based on tests performed using sawdust, which due to its small particle size and material properties, is an ideal biomass material to use in this application. Future tests of these systems using a wider array of biomass materials will determine their share of the biomass power market. However, it should be noted that the engineers at BIOTEN have overcome many of these obstacles sufficiently to allow for commercial scale demonstration of the technology. In some cases, this has meant compromising efficiency, but the facility is a necessary first step in largerscale demonstrations and commercialization. Currently, the BIOTEN facility is rated at $5 \mathrm{MW}$ net and in the short term, plants using this technology are expected to stay below 25 MW. Larger systems and higher cycle efficiencies may be possible with modifications that would include combined cycle configurations. A diagram of BIOTEN's facility is provided as Exhibit 10.2-1.

\subsection{Fuel Cells}

Currently, three different types of fuel cells are receiving a majority of the attention from researchers and pilot project developers: phosphoric acid (PAFC), molten carbonate (MCFC), and solid oxide (SOFC). Of these, PAFCs are the furthest along in development. In fact, there are over $40 \mathrm{MW}$ of PAFC demonstration units in operation around the world ranging in capacity from about $25 \mathrm{~kW}$ to $11 \mathrm{MW}$. These units, operating mostly on natural gas, have efficiencies between 37 to 42 percent. However, cell lives, voltage decays, and leakage problems have somewhat dampened expectations for these systems. MCFCs offer potentially higher efficiencies (50 to 60 percent) than PAFCs with some additional benefits. Cells may be less costly to fabricate and the rejected heat is of sufficient temperature to be used in combined cycle or cogeneration applications. Several pilot projects are underway, such as the $2 \mathrm{MW}$ Santa Clara

EXHIBIT 10.3-1 ERC MCFC System

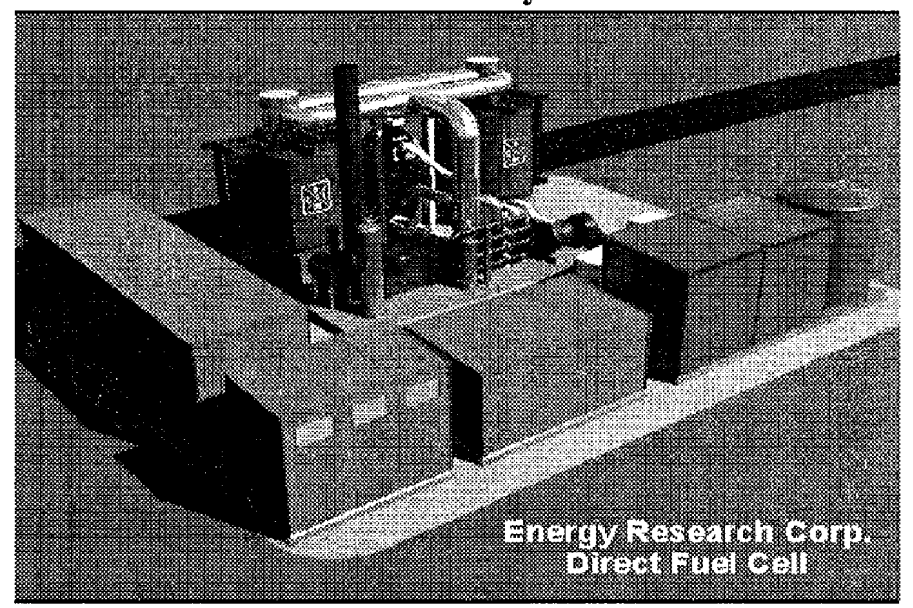

project. SOFCs are also now undergoing testing at several facilities. Westinghouse has already delivered $25 \mathrm{~kW}$ units and is expected to deliver a $100 \mathrm{~kW}$ unit. Efficiencies for these systems are also expected to be very high, as are the operating temperatures. These high operating temperatures may be useful in cogeneration or possibly in combined cycle operation. SOFCs feature solid state cell elements and simpler designs. However, MCFCs have the advantage of being able to convert more of the gas constituents (carbon monoxide and methane as well as hydrogen) into electricity; this makes them even more suitable for power generation utilizing low- $\mathrm{H}_{2}$ gases such as those derived from biomass. 
Adaptation of MCFCs for use with biomass fuels will require biomass gasification. Coupling a biomass gasifier and a MCFC has not yet been demonstrated. However, it is expected that gasification will be accomplished using a variety of commercially available units or gasifiers currently under development. Effective gas clean-up will be of utmost importance in implementing this technology. The presence of even low levels of trace metals, halogen compounds, sulfur, tars, oils, and arsenic may adversely affect the fuel cells' efficiency and service life. On the other hand, coupling these systems may provide opportunities to take advantage of thermal and chemical synergies that have yet to be determined. The success of this type of power generation system will probably depend on the effective selection of equipment, and the extent to which components can be modified without large sacrifices in efficiency. Refer to Exhibit 10.3-1 for an illustration of a possible biomass-based fuel cell.

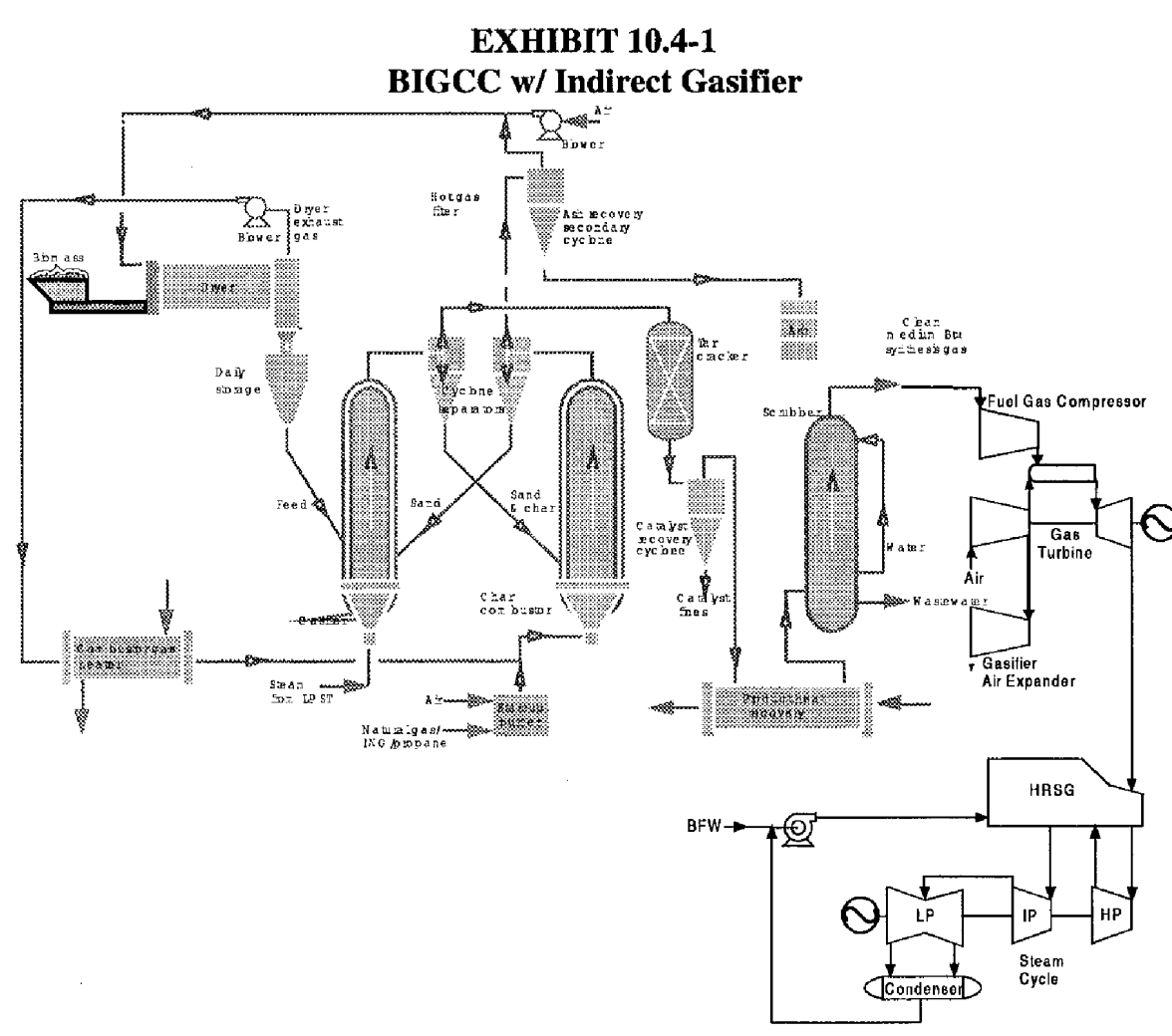

\subsection{Biomass Integrated Gasification Combined Cycles (BIGCC)}

BIGCCs promise to offer some of the highest biomass power efficiencies using technologies that are well along in development. Several gas turbine manufacturers have stated that they will honor the warranties on their engines if low-Btu, clean, alternative fuels are used in some of their machines. In fact, there is considerable interest by these manufacturers in exploring the marketing and sales opportunities associated with these cycles. The development of these systems is helped considerably since some of the major components of these systems represent proven technology. The gas turbines, steam turbines, and generators in these plants would be configured like their fossil-fired cousins. The DOE coal gasification program has also provided relevant data to allow refinements to BIGCC performance estimates. Further, with the exception of the gasification plant, power generators are familiar with this type of system and BIGCCs may attract project developers who are reluctant to implement more exotic concepts such as fuel cells.

BIGCCs are likely to have capacities in the range of 20 to $80 \mathrm{MW}$ range, and are likely to be employed in greenfield development projects and repowering. These systems will be used to meet the power or thermal needs of the industrial users or in utility applications.

Gasification of biomass presents the same problems in this configuration as it does in some of the other systems reviewed in this report. As an example, product gas must be free of erosion-causing particulates or compounds that would contribute to turbine blade fouling. Refer to Exhibit 10.4-1 for a diagram of a BIGCC using an indirect gasifier. 


\subsection{KEYS TO SUCCESSFUL BIOMASS POWER PROJECTS}

Like other power projects, biopower projects will have to be assessed on a case-by-case basis. With impending restructuring of the U.S. electric industry, cost will be the overarching concern for all electricity generators. Thus, the decision to repower existing plants or build new power plants using biomass as a fuel will depend on each generator's economic and environmental priorities and strategies for providing competitively priced electricity. Advanced biopower projects that are seeking to increase plant efficiencies, lower production costs, and lower capital costs are underway worldwide. These projects are in various stages of completion and some have been mentioned in this report. Based on the experiences gained through development of the projects it is apparent that certain elements are necessary to implementing successful biopower projects in the U.S. They are listed below. ${ }^{65}$

\section{1) Build partnerships with key stakeholders}

Because biopower projects involve several sectors of the economy, a comprehensive problem-solving approach is required to ensure their success. Strong partnerships among all the key players is a necessity. These players include industry, regulatory institutions, advocacy/research groups, academia, and the agricultural community. New York's Salix project, for example, involves utilities, research groups, universities, DOE, and the USDA. The Minnesota project involves a utility, an alfalfa grower cooperative, biomass technology developers, universities, and other local/regional research organizations.

\section{2) Create a clear technology vision and manage technology placement}

The technology will succeed only if it is understood and applicable to the customer's situation. Biopower projects are site-specific, so a technology tailored to the available resources and ultimate needs of the end-user is essential to long-term success.

\section{3) Understanding the forces influencing the target market}

Project developers must be farsighted in their investment vision. This involves tailoring the products and services to meet the changing needs of the ultimate customer, and keeping up-to-date on environmental, energy, and agricultural regulations, and trends in development and land use.

\section{4) Expand concept of innovation}

Innovation is needed to improve technology, but it is also needed to improve the manufacturing process and productivity. Biopower is still expensive relative to other power generation technologies, so innovation at all levels must be relied on to help bring the costs down. The fossil-fired competition is composed primarily of mature, well understood technologies that have been improved over decades of innovation. Competing in a freewheeling market will take imagination and fortitude.

\section{5) Willingness to expand market focus}

Many developing countries are potential markets for biopower. Countries with large agrarian sectors, growing economies, growing demand for electricity, good biomass resource potential, and government

\footnotetext{
${ }^{65}$ Peterson, Jeffrey M., 1995, "Successful Strategies for Bioenergy Commercialization: The New York State Model," in Proceedings from the Second Biomass Conference of the Americas: Energy, Environment, Agriculture, and Industry, Portland, OR, Aug. 21-24, pp. 1572-1581.
} 
support for renewable energy are the best targets. U.S. developers can expand their focus to include countries such as India, Brazil, and China.

\section{6) Increase information base and dissemination}

It is important to obtain more data on biopower projects and then inform the public and stakeholders on the costs/benefits of bioenergy. Without general public support, especially in a restructured electric industry environment where the consumer can choose between power suppliers, biopower projects will not achieve long-term success. 


\subsection{CONCLUSION}

Opportunities for biomass power in the United States will continue to be available in areas where steam/electricity can be produced at rates competitive with low-cost fossil-fired generation. Industries or power generators that can take advantage of steady, local, and low cost biomass residues are also the most likely candidates for sustained biomass power growth. To the extent that environmental benefits can be valued, $\left(\mathrm{CO}_{2}\right.$ neutrality, low $\mathrm{SO}_{2}$ emissions) biomass may demonstrate an edge over fossil-fired generation as a green, technically proven power generation technology. However, in the long term, biomass power must either be competitive on a production cost basis (including environmentally tradeable benefits) or be continuously supported with government programs that encourage its development. The former is the best way to ensure long-term market viability, while the latter provides less incentive for technological improvement or international market development, where government policies may not provide as fertile a market.

Specific technologies have emerged with the potential to dramatically change the existing domestic biomass power market. The changes include higher efficiencies, lower production costs, and increased prime mover flexibility. Gasification technologies for biomass feedstocks and black liquor gasification in particular, represent promising ways for biomass to be integrated into industrial processes, improving their ability to generate power/steam. The domestic power industry continues to show interest in co-firing as a short term and technically feasible means of introducing biomass into its power generation profiles. Repowering with biomass offers another possible strategy to supplement fossil-fired generation. These technologies represent important hybrid strategies that in the long run may be the best solution for power generators and the environment.

Biomass power is already important in meeting the electric/thermal demands of the United States. The extent to which its role develops will depend on continued technical progress (generation and feedstock) and public support for renewable technologies. This will be more important in a restructured electricity market that will be primarily based on competitive costs of electricity. In Volume II, the reader is invited to look at the international market and realize that biomass power has its place in the global power market as well. Successful growth in biomass power, and renewable power generation in general, is not just a domestic whim. Opportunities exist worldwide, and the domestic market will have as much to learn from global experiences as the rest of the world has to learn from U.S. efforts. 


\section{VOLUME II \\ International Market Opportunities for Biomass Power}

\section{TABLE OF CONTENTS}

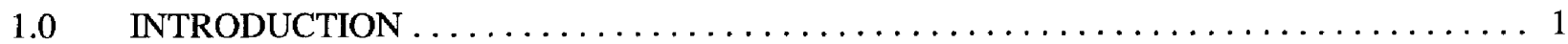

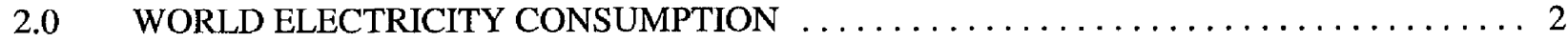

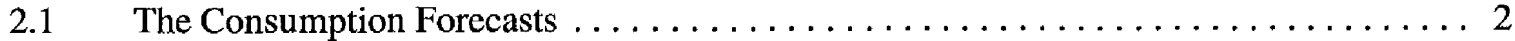

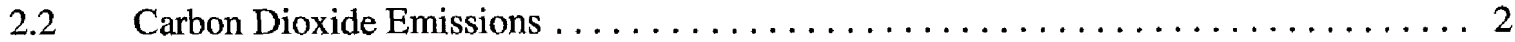

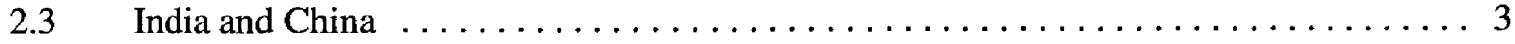

2.3.1 Projected Biomass Electric Capacity . ................... 5

2.3.2 Technical Potential of Biomass Resources $\ldots \ldots \ldots \ldots \ldots \ldots \ldots \ldots \ldots$

2.3.3 Examples of Biomass Power Efforts . . . . . . . . . . . . . . . . 7

2.3.4 Potential Applications of Biomass Power ................. 8

$3.0 \quad$ INFRASTRUCTURE FINANCING ISSUES $\ldots \ldots \ldots \ldots \ldots \ldots \ldots \ldots \ldots \ldots \ldots \ldots \ldots$

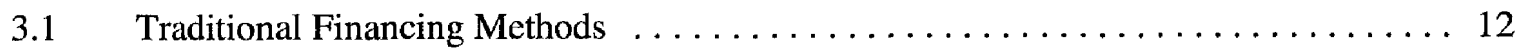

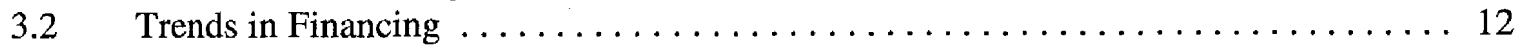

3.2.1 Independent Power Projects and Project Finance $\ldots \ldots \ldots \ldots \ldots \ldots \ldots$

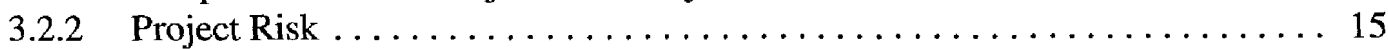

3.2.3 Future of Power Market Development $\ldots \ldots \ldots \ldots \ldots \ldots \ldots \ldots \ldots$

4.0 INDIA-ENVIRONMENT FOR BIOMASS PRIVATE POWER DEVELOPMENT $\ldots \ldots 20$

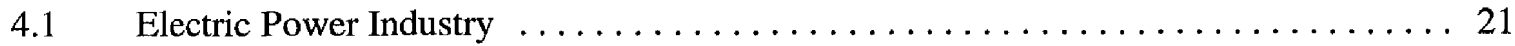

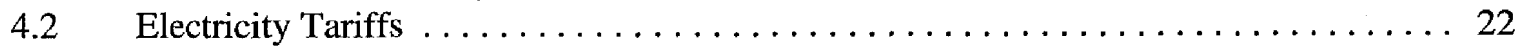

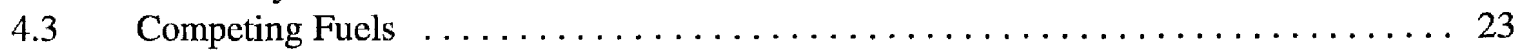

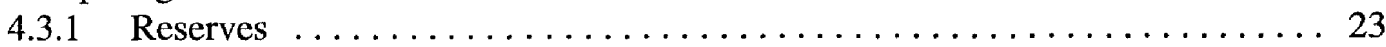

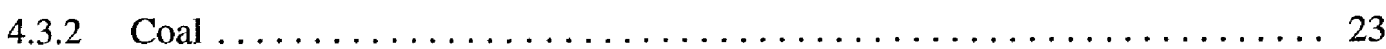

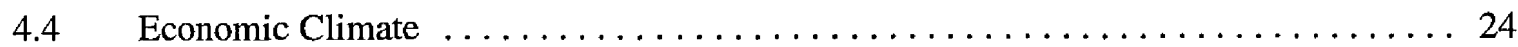

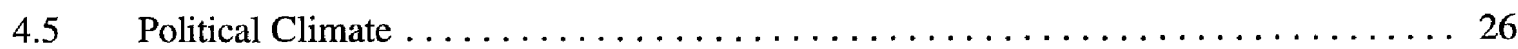

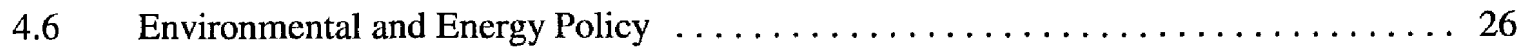

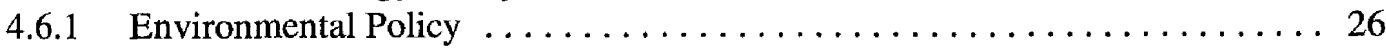

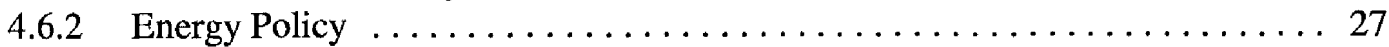

$4.7 \quad$ Investment Climate . . . . . . . . . . . . . . . . . . . . . . . . . 29

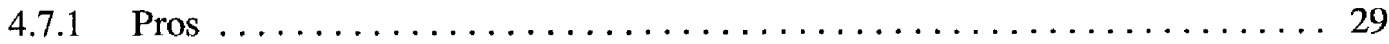

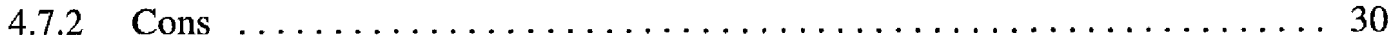

4.8 Background for the International Private Power Developer in India $\ldots \ldots \ldots \ldots \ldots 31$

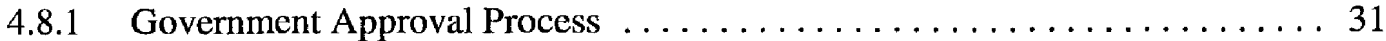

4.8.2 Renewable Private Power Projects Currently in Development .......... 32

4.8.3 Recent Renewable Private Power Project Solicitations and Initiatives . . . . . 33

4.8.4 Sample List of Companies Currently Doing Business in India . . . . . . . . . . 34

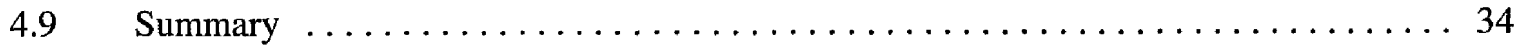

5.0 CHINA-ENVIRONMENT FOR BIOMASS PRIVATE POWER DEVELOPMENT . . . . 35

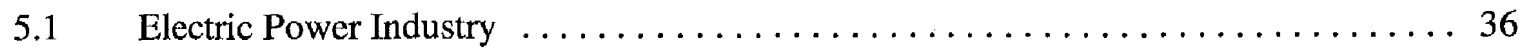

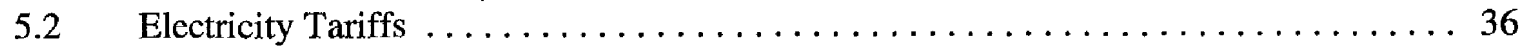

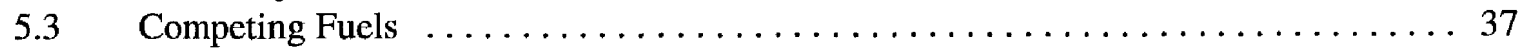

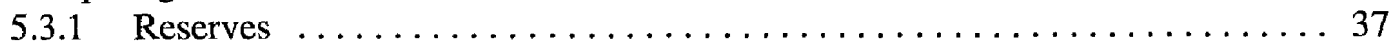

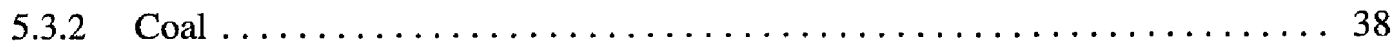




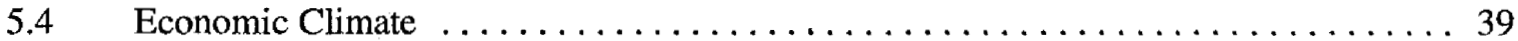

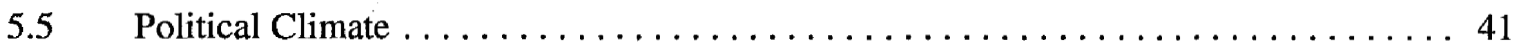

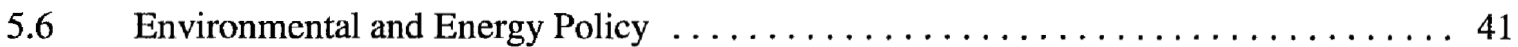

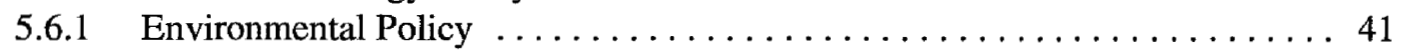

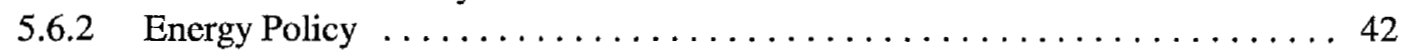

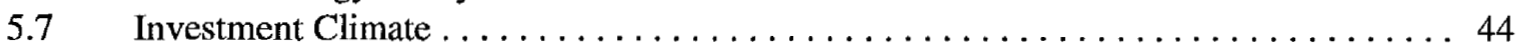

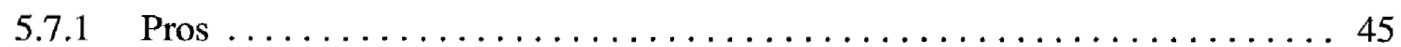

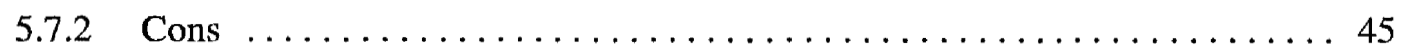

$5.8 \quad$ Background for the International Private Power Developer in China .......... 46

5.8.1 Government Approval Process . . . . . . . . . . . . . . . 46

5.8.2 Renewable Private Power Projects Currently in Development . . . . . . . . 47

5.8.3 Recent Renewable Private Power Project Solicitations and Initiatives . . . . . . 47

5.8.4 Sample List of Companies Currently Doing Business in China . . . . . . . . 48

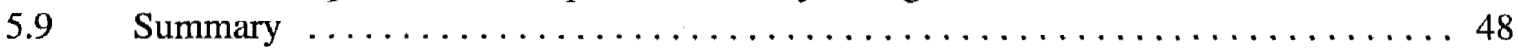

6.0 OTHER TARGET COUNTRIES $\ldots \ldots \ldots \ldots \ldots \ldots \ldots \ldots \ldots \ldots \ldots \ldots \ldots \ldots \ldots$

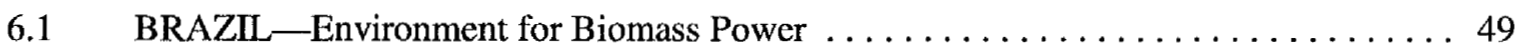

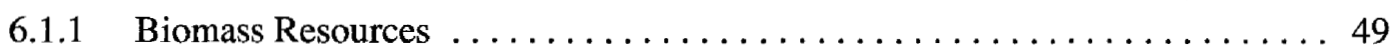

6.1.2 Examples of Biomass Power Efforts $\ldots \ldots \ldots \ldots \ldots \ldots \ldots \ldots \ldots \ldots$

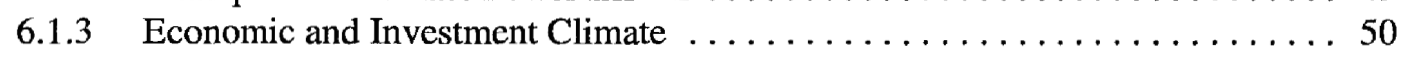

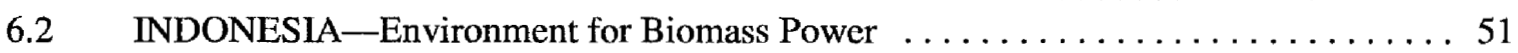

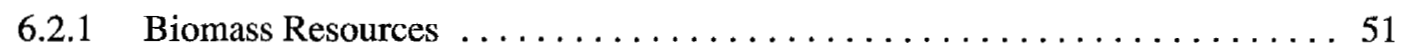

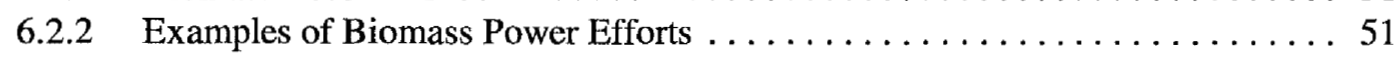

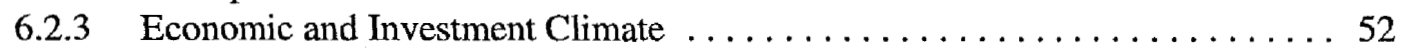

6.3 PHILIPPINES —Environment for Biomass Power $\ldots \ldots \ldots \ldots \ldots \ldots \ldots \ldots \ldots \ldots$

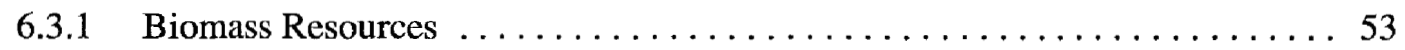

6.3.2 Examples of Biomass Power Efforts . . . . . . . . . . . . . 53

6.3.3 Economic and Investment Climate $\ldots \ldots \ldots \ldots \ldots \ldots \ldots \ldots \ldots \ldots$

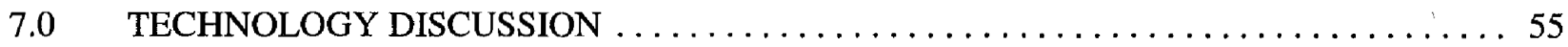

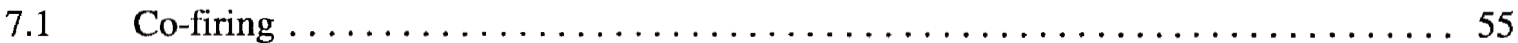

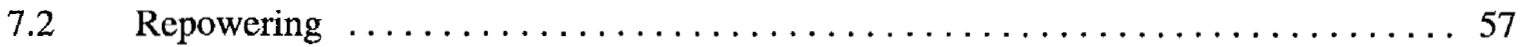

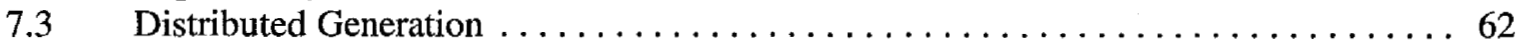

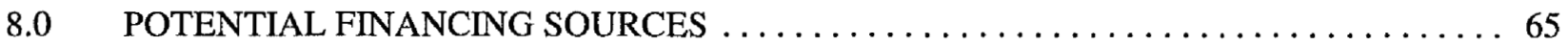

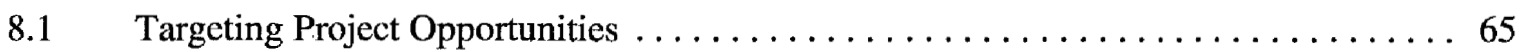

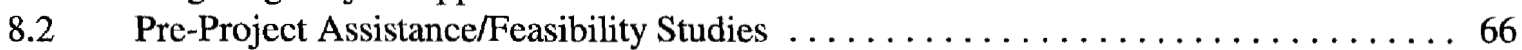

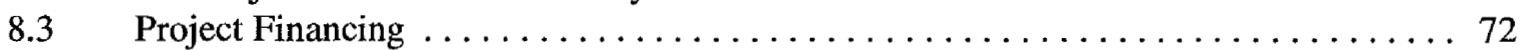

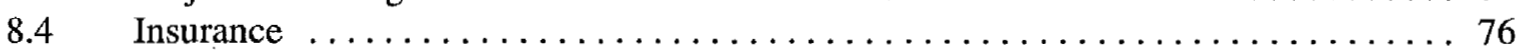

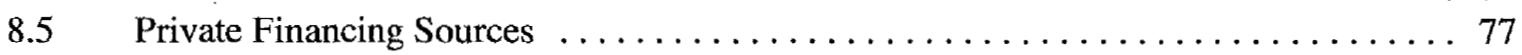

$9.0 \quad$ CONCLUSION $\ldots \ldots \ldots \ldots \ldots \ldots \ldots \ldots \ldots \ldots \ldots \ldots \ldots \ldots \ldots \ldots \ldots$

References

Appendix 1: Environmental Regulations in India

Appendix 2: Environmental Regulations in China

Appendix 3: Internet Web Page Addresses and List of Contacts for India and China

Appendix 4: $\quad$ Sample Forms and Instructions for Financial Assistance 


\section{EXHIBITS}

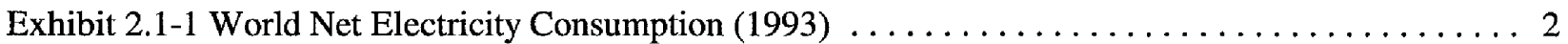

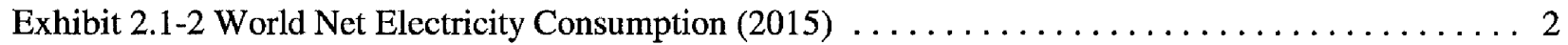

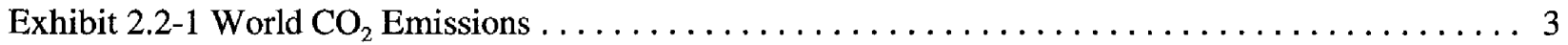

Exhibit $2.3-1$ Total Electricity Consumption China $(1990-2015) \ldots \ldots \ldots \ldots \ldots \ldots \ldots \ldots \ldots$

Exhibit $2.3-2$ Total Electricity Consumption India $(1990-2015) \ldots \ldots \ldots \ldots \ldots \ldots \ldots \ldots \ldots$

Exhibit 2.3-3 Estimates of Biomass Electric Capacity $(\mathrm{GW}) \ldots \ldots \ldots \ldots \ldots \ldots \ldots \ldots \ldots \ldots \ldots \ldots \ldots \ldots$

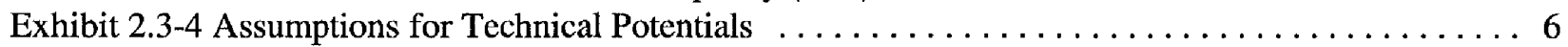

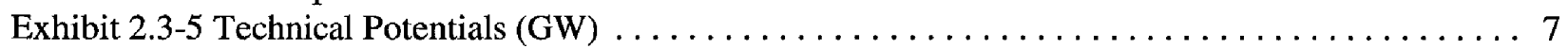

Exhibit 3.2-1 Top 10 Independent Power Developers of $1996 \ldots \ldots \ldots \ldots \ldots \ldots \ldots \ldots \ldots \ldots$

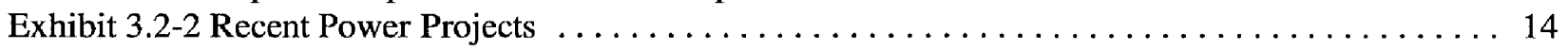

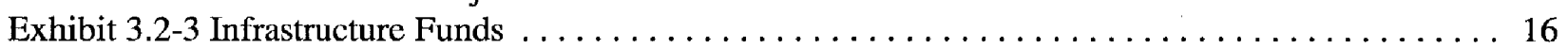

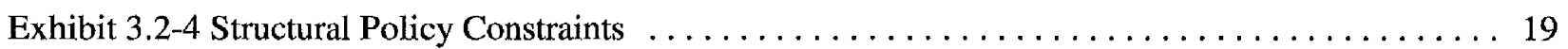

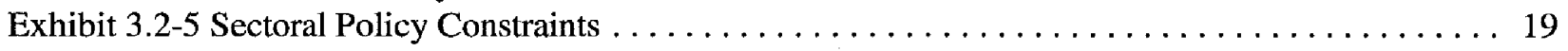

Exhibit 7.3-1 Summary of Economic Size Ranges for Each Technology $\ldots \ldots \ldots \ldots \ldots \ldots \ldots \ldots$ 


\subsection{INTRODUCTION}

International opportunities for biomass-generated electricity are extremely varied. Bioenergy can be used in industrial applications and for rural electrification and it can support a small stand-alone unit or a larger captive plant. It can use many different resources as fuel and it can be used to offset some of the environmental emissions associated with fossil-fueled power plants. International private power opportunities are also complex and varied. There is no single "template" for a successful project and developers often face completely different circumstances even within the same country.

While biopower is of interest to governments, the agricultural sector, industry, and environmental groups, this report is aimed at assisting the private power developer with developing international biopower projects. The chart below highlights the important steps in a successful project. This report focuses on the feasibility study, financing, and business development aspects of an international biopower project.

Because they are unique to each project, specific fuel contracts and power purchase agreements (PPA) are not covered in this report.

The countries with the largest future growth in demand for power are India and China, so this report begins with a discussion of their future electricity demand, biomass resource, and biopower potential. The rapid pace of policy changes and a lack of state- or local-level data make identifying specific opportunities within a country beyond the scope of this report. Next, the general issues and trends in international power project financing are discussed. The report continues with an examination of the specific financial/policy incentives affecting renewable and biomass power development in India and China. After briefly describing the climate for private biopower in three other countries, Brazil, Indonesia, and the Philippines, the report discusses various biomass technology options. The report concludes with an overview of potential financing sources for renewable power in these target countries.

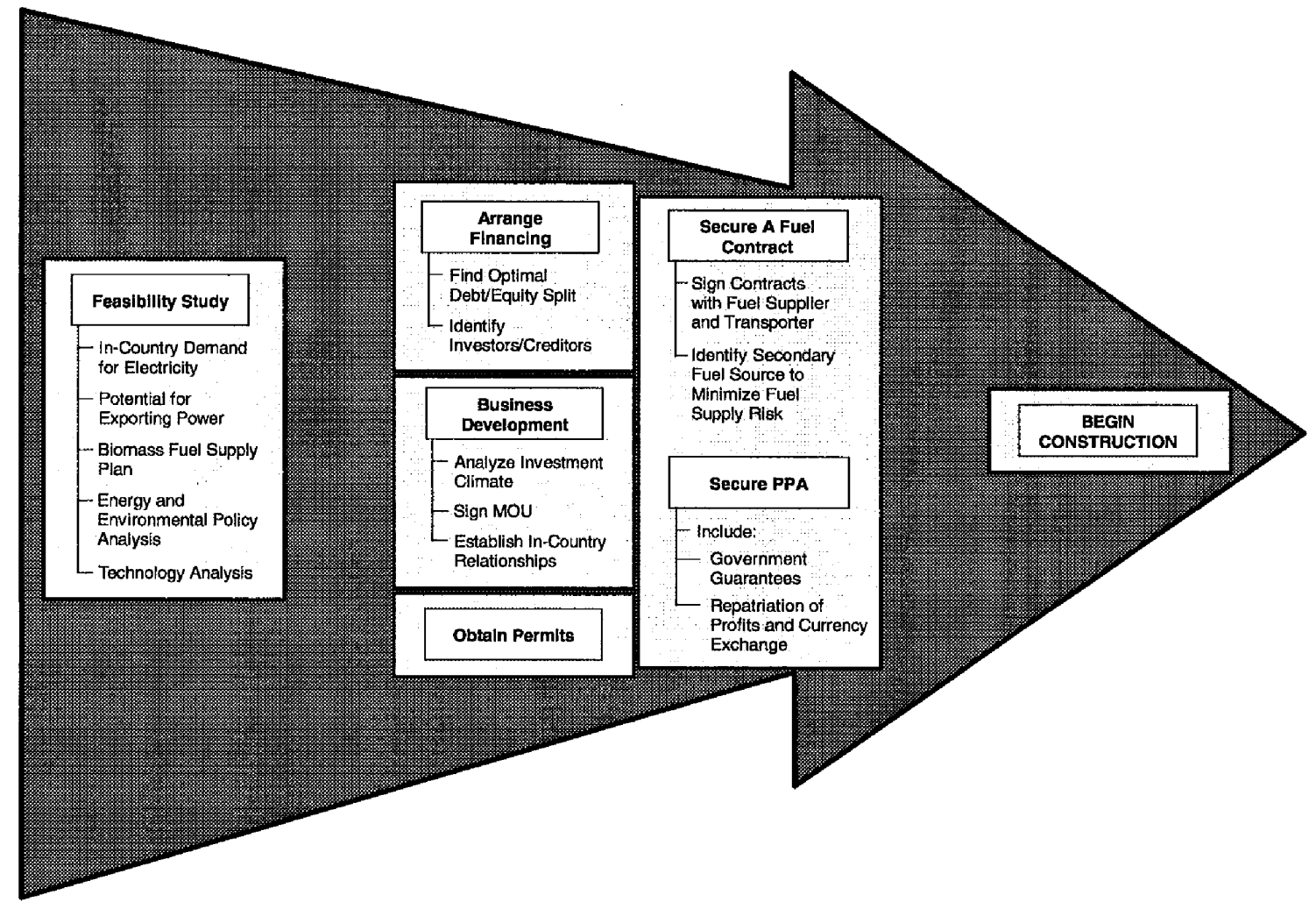

International Biomass Power Project Development 


\subsection{WORLD ELECTRICITY CONSUMPTION}

\subsection{The Consumption Forecasts}

According to U.S. Department of Energy/Energy Information Administration (DOE/EIA) calculations, in 1993 net electricity consumption for the world was 10,761 terawatt-hr. (TWh), with China and India together comprising approximately 9 percent of the total (Exhibit 2.1-1). In DOE/EIA's baseline calculations, ${ }^{1}$ by 2015 , China alone will represent nearly 13 percent of the world's electricity consumption at 2,457 TWh and India will represent 5 percent at 962 TWh (Exhibit 2.1-2). Relative to growth projections for other countries, China and India will experience the largest increases in electricity consumption over the next twenty years. The importance of these two countries' contribution to world electricity demand is such that they are discussed specifically in upcoming sections of this report.

World Net Electricity Consumption 1993

(Total TWh $=10,761)$

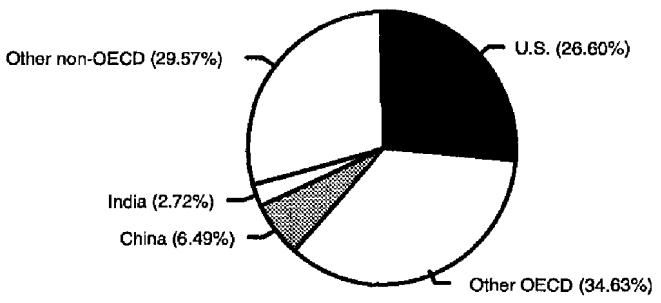

EXHIBIT 2.1-1
World Net Electricity Consumption 2015

(Total TWh $=19,087$ )

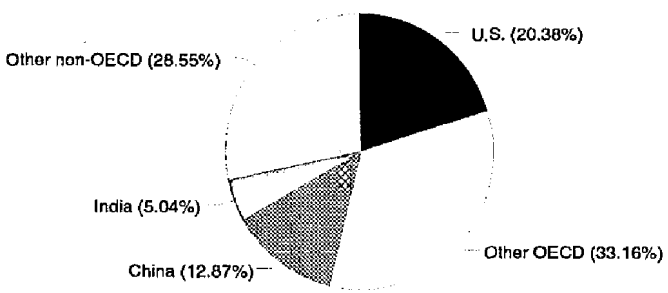

EXHIBIT 2.1-2

Electricity demand is a function of numerous factors including economic growth, population, income growth, and urbanization. Economic growth and electricity demand are strongly and mutually related. A maturing economy requires more power and the availability of reliable power spurs economic growth. The remaining factors, population, income levels, and urbanization generally serve more as stimulants for electricity demand. A rise in population alone will not lead to an increased demand for power; a per capita demand increase will only occur when the growing population enjoys rising income levels. When income levels rise, the consumer base expands. Consequently, this larger consumer base demands more appliances and other electricity-consuming products.

Urbanization fuels a similar trend. History has shown that as a country develops economically, it urbanizes to create a concentrated pool of producers and consumers. Thus there is an economic case for providing relatively more power in an area with a higher density of population and industry. In the long term, as the nation's entire economy matures, the split between urban/rural power demand will shrink.

\subsection{Carbon Dioxide Emissions}

Concerns about the possible threat of global climate change usually arise in discussions of worldwide electricity consumption. Most of the Organization for Economic Cooperation and Development (OECD)

1 DOE/EIA, 1996, International Energy Outlook 1996. 
countries and the European Union have expressed determination to limit greenhouse gas emissions. About a fifth of current emissions originate in the developing world, a share expected to grow to nearly a third by 2015. Energy-related carbon dioxide $\left(\mathrm{CO}_{2}\right)$ emissions in these countries are perceived as the major culprit-most of this is due to the expanded use of coal in both power generation and industry. Exhibit 2.2-1 shows the world $\mathrm{CO}_{2}$ emissions for 1990 and projections for 2010, based on International Energy Agency (IEA) calculations. ${ }^{2}$ To put these figures in some perspective, in 1995, electric utilities in the U.S. emitted a total of 1.8 billion tonnes of $\mathrm{CO}_{2 .}{ }^{3}$ This represents approximately 34 percent of total U.S. $\mathrm{CO}_{2}$ emissions of 5.3 billion tonnes.

\section{World CO2 Emissions}

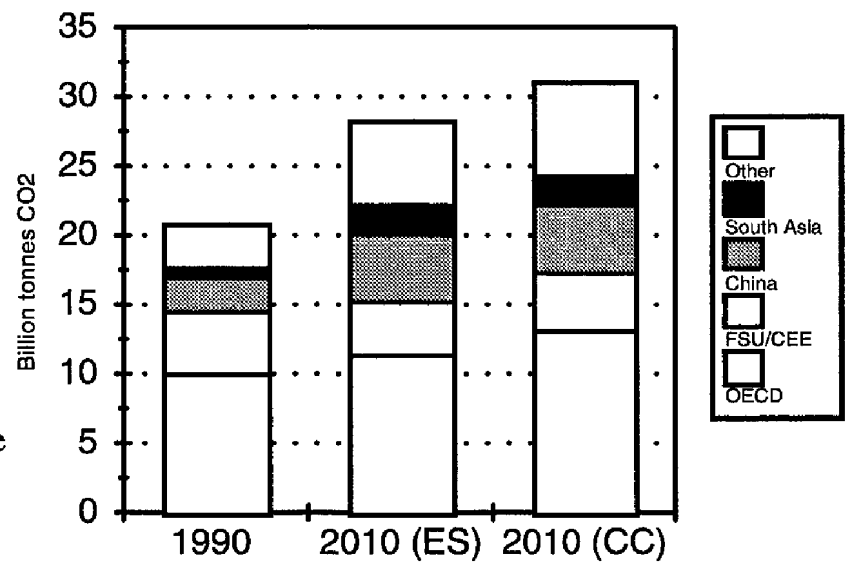

The projections reflect two IEA scenarios: the Energy Savings (ES) Case and the Capacity Constraints (CC) Case. The ES Case reflects higher efficiency, baseline economic growth and population assumptions, and flat energy prices. The CC Case combines the baseline GDP and population assumptions with rising energy prices and historical trends in energy efficiency.

As shown in this exhibit, $\mathrm{CO}_{2}$ emissions will increase most in the non-OECD/FSU/CEE world. This is particularly true in China, East Asia, and South Asia (which includes India). In 1990, China alone accounted for nearly 10 percent of the world's $\mathrm{CO}_{2}$ emissions, and its energy sector was responsible for 82 percent of this amount. ${ }^{4}$ According to IEA, China's share will double to 16.5 percent of total world $\mathrm{CO}_{2}$ emissions by 2010 (similar data were not available for India). ${ }^{5}$ In the developing world, despite good environmental intentions, fossil-fired power plants are less likely to have strict environmental controls enforced upon them. If biomass-fueled power is used in place of these heavier polluting plants, it can help countries like China reduce some of their energy-related $\mathrm{CO}_{2}$ emissions.

\subsection{India and China}

At 914 million and 1.2 billion people, respectively, India and China together account for approximately 40 percent of the world's population. ${ }^{6}$ Over the next two decades, these two countries are expected to undergo the largest growth in electricity consumption in the world. This increase will be fueled by their strong economic growth, large populations, and interest in rural electrification.

\footnotetext{
${ }^{2}$ International Energy Agency, 1996, World Energy Outlook: 1996 Edition, p. 59. FSU is the Former Soviet Union and CEE is Central and Eastern Europe.

${ }^{3}$ DOE/EIA, 1996, Emissions of Greenhouse Gases in the United States 1995, October, p. 19.

${ }^{4}$ Braatz, et al., eds., 1996, Greenhouse Gas Emission Inventories: Interim Results from the U.S. Country Studies Program, pp. 8-11.

$516.5 \%$ is an average of the $\mathrm{CC}$ case projection $(16 \%)$ and the ES case projection (17\%).

${ }^{6}$ World Bank, World Data 1995.
} 
India and China are complex markets because of the ambiguities between their traditional structures and philosophies and the economic necessity of opening their markets to outside investors.

Although they have followed markedly different political paths, historically, both philosophies have been based on self-reliance, usually against open trade. Expanding economies have forced each country's government to reassess this dichotomy in historic traditions and future changes, and institute reforms much faster than anticipated. In the case of India, this means opening its markets and liberalizing its economy so capitalism can thrive. For China, this means changing a mode of thought that is ingrained in a political vision and agenda. Since the electric power sector is one of the foundations of a healthy economy, this dichotomy has surfaced very rapidly. In many ways, the manner and pace with which these countries allow international private power to operate within their borders will determine the climate for future business and trade development.

Exhibits 2.3-1 and 2.3-2 illustrate the low, reference (or baseline), and high growth cases for total electricity consumption in China and India based on DOE/EIA's International Energy Outlook 1996 estimates. In the reference case, DOE expects total worldwide economic activity to grow at an average annual rate of 3 percent from 1993 to 2015 . The low growth case for China assumes a zero gross domestic product (GDP) growth rate and for India, it assumes a 1.5 percent annual rate of GDP growth. For both countries, the high-growth case assumes a 4.5 percent annual rate of economic growth. As the graphs show, even in the low-growth cases, each country will more than double its power consumption by 2015 .

Total Electricity Consumption China (1990-2015)

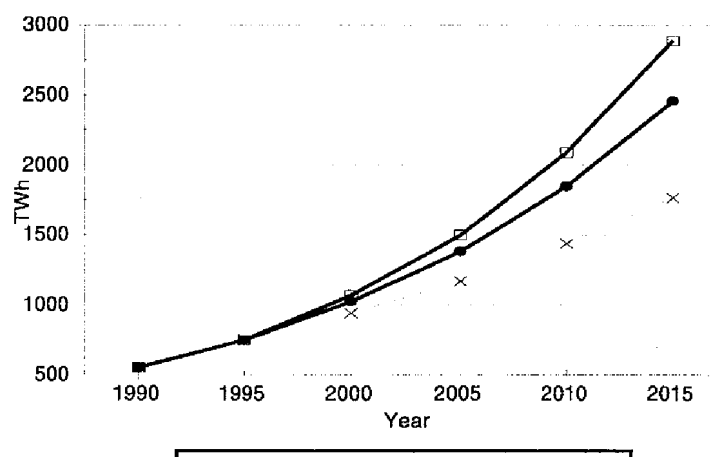

$\rightarrow$ - Low Growth-Reference - $\rightarrow$ - High Growth

EXHIBIT 2.3-1
Total Electricity Consumption India (1990-2015)

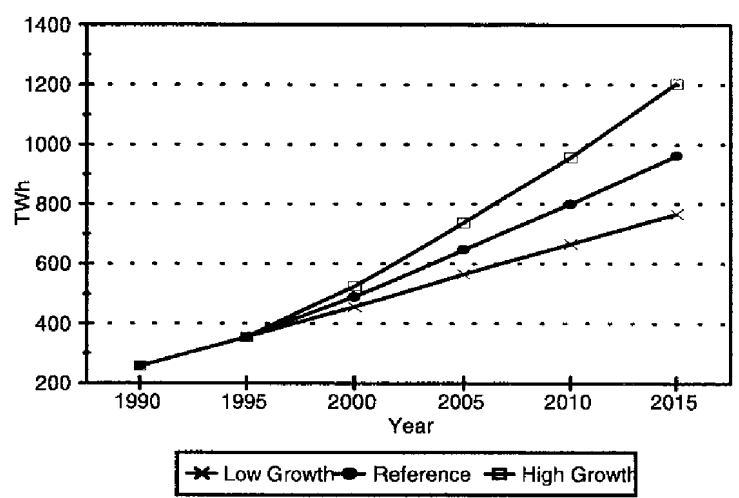

EXHIBIT 2.3-2 


\subsection{Projected Biomass Electric Capacity}

Exhibits 2.3-1 and 2.3-2 represent total electricity consumption in China and India. Unfortunately, there is little available information specifically on the amount of power generated from biomass in these two countries. For the 1995 U.S. reference case, DOE/EIA estimated that biomass generating capacity (excluding municipal solid waste and co-firing) was approximately $7.5 \mathrm{GW} .{ }^{7}$ Antares developed the reference and high growth cases for India and China using EIA projections for biomass growth (plus capacity additions reflecting co-firing applications) in the U.S. For the India projections, U.S. biomass capacity was accelerated by 5 years starting in the year 2000 due to expected larger penetration rates compared to the U.S. Biomass growth in China was not accelerated due to its less-developed governmental and legislative vision for biomass power; ${ }^{8}$ thus, projections for China follow the U.S. growth rate projections.

In the high-growth case for the U.S., co-firing was assumed to result in more than $6 \mathrm{GW}$ of biopower capacity, implemented linearly over the twenty-year period. This is equal to 53 percent of the total biopower capacity of $11.3 \mathrm{GW}$. Applying this same ratio yields approximately $5 \mathrm{GW}$ of co-firing capacity for China in the high growth case. In the U.S. reference case, co-firing was assumed to be implemented at one-third the rate of the high-growth case. Exhibit 2.3-3 shows the results of the projection for biomass capacity (including co-firing applications) for India and China.

When biomass-generated power was commercially introduced in the U.S., the country was already fully electrified, so it served the bulk power market mainly through niche applications. India and China, however, are still trying to meet basic power needs, so biomass can be introduced as a more integral part of their fuel mix.

Furthermore, the high-growth scenario only reflects the upper bound of economic growth and total electricity consumption. It does not incorporate a fuel mix different from that assumed in the reference case. Thus, the estimates of biomass as a percent of the total may actually be very different from the estimates in Exhibit 2.3-3. Biopower and other renewable energy sources have to have government support and financial incentives; economic development alone will not create more demand for biopower. In addition,

Estimates of Biomass Electric Capacity (GW)

\begin{tabular}{|l|c|c|}
\hline & $\begin{array}{c}\text { Reference Case } \\
2015\end{array}$ & $\begin{array}{c}\text { High Growth Case } \\
2015\end{array}$ \\
\hline China & 5.4 & 9.2 \\
\hline India & 2.3 & 4.5 \\
\hline U.S. & 5.8 & 11.3 \\
\hline
\end{tabular}

A capacity factor of $80 \%$ was used to convert from TWh to MW. (This capacity factor is probably optimistic given the current situation in most developing countries, but is likely to represent the efficiency associated with new capacity.)

source: $D O E / E I A$

EXHIBIT 2.3-3 abundantly available fuels such as coal and hydro may be a preferred way to meet rapidly growing power demands. Actual biomass capacity additions will strongly depend on how these countries approach alternative energy and environmental issues.

\footnotetext{
7 DOE/EIA, 1996, Annual Energy Outlook 1996, p. 96.

${ }^{8}$ See chapter 5 of this report for further discussion.
} 


\subsubsection{Technical Potential of Biomass Resources}

The technical potential represents the maximum upper limit to a biomass resource's ability to support power generation based on certain assumptions. ${ }^{9}$ This criterion focuses on the technical viability of the various fuel sources in a given year and provides a means to quantitatively compare biomass resources among countries. Energy crop, sugar refining residues, agricultural residues, and industrial roundwood residues were chosen as the most viable biomass resources. In these calculations, agricultural residues include those from wheat, rice, maize, and sugar beet crops. The maximum amounts of electrical capacity that could be supported by current agricultural activity, sugar production, and logging activity were calculated by using the respective production, residue generation, recovery rate, heating value, and efficiency assumptions. ${ }^{10}$ Residue collection rates were not included because of data limitations.

The energy crop and sugar production technical potential numbers reflect the maximum number of gigawatts given the set of specific assumptions about land use and technology outlined in Exhibit 2.3-4. ${ }^{11}$ Since it is probable that, in most cases, developing countries do not yet have the advanced technology, the sugar conversion figure can overestimate the actual potential of sugarcane residue.

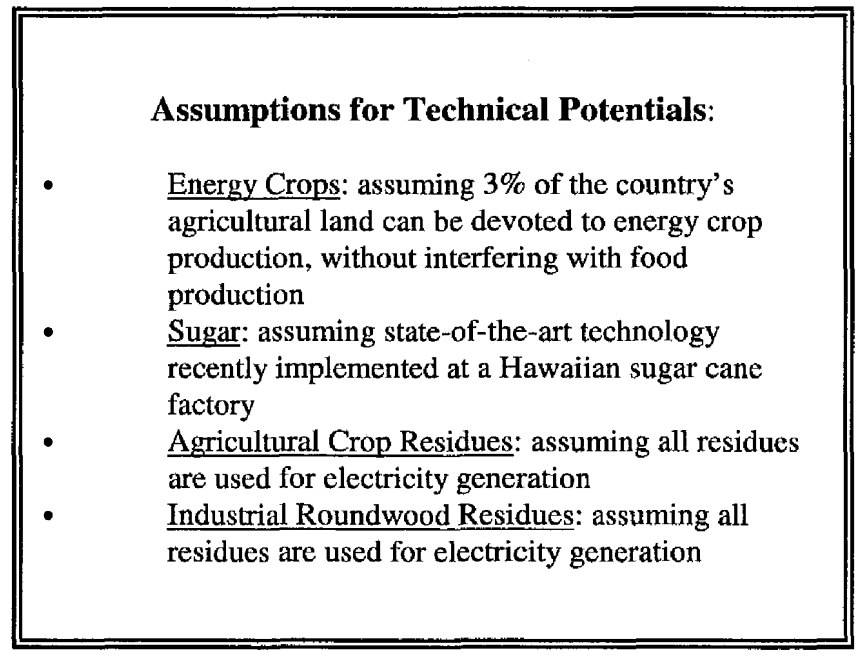

EXHIBIT 2.3-4
Due to a lack of corresponding data on residueto-power conversions for agricultural crops and industrial roundwood, their technical potential numbers represent the maximum number of gigawatts that can be supported if all available residues were used for electricity generation. Because this analysis is intended as an indication of the countries' ability to support biopower development, this distinction has to be interpreted in a larger context. Residue availability for electricity production is affected by the opportunity cost of using the residues. Agricultural residues are also affected by limited access to water in rural areas of most developing countries and dated irrigation techniques that may not make the most efficient use of available land. Because there are competing uses for the residues, it is not realistic to assume that one hundred percent of them will be used for electricity generation. If greater benefits are attributed to other uses such as compost, animal bedding, or furniture manufacture, then the residues will be diverted to those uses.

Exhibit 2.3-5 lists the technical potentials for China, India, and the U.S. for comparison. Note that these four resources cannot be combined to obtain a total technical potential number because they do not represent the same level of availability. As stated above, the energy crop and sugar potentials incorporate

\footnotetext{
9ndia's sugar industry may have greater potential than this section indicates; see section 2.3 .4 for explanation.

${ }^{10}$ For a full discussion, see Antares Group, Inc., 1996, Repowering Applications and Markets for Biomass Fuel Integration and Augmentation, July 22.

${ }^{11}$ Energy crop assumption from: Turnbull, Jane, 1993, Strategies for Achieving a Sustainable, Clean and Cost-Effective Biomass Resource, p.5. and sugar assumption from: Jakeway, Lee, Winrock International, 1996, personal communication. This assumes that the residue (bagasse) from producing one pound of sugar can generate $120 \mathrm{kWh}$ of power.
} 
specific assumptions, but the agricultural and industrial roundwood figures represent the maximum amount of residue available under current practices, so adding these figures together would overstate the actual amount of residue available.

EXHIBIT 2.3-5

Technical Potentials (GW)

\begin{tabular}{|l|c|c|c|}
\hline & CHINA & INDIA & U.S. \\
\hline Agricultural production residues & 76 & 33 & 60 \\
\hline Industrial roundwood residues & 13 & 3.6 & 60 \\
\hline Energy crops & 46 & 17 & 40 \\
\hline Power generated at sugar mills & 1.1 & 2.5 & 1.1 \\
\hline
\end{tabular}

\subsubsection{Examples of Biomass Power Efforts}

India is a predominantly agricultural economy and has traditionally used biomass resources for energy. Biopower has been a major tool of rural electrification programs and the government is pushing the development of bagasse-fired cogeneration units at the country's 400 sugar mills. Specific efforts include studying ways to improve the performance and efficiency of biomass gasifiers and biogas plants, and analyzing village-level biomass uses such as wood, dung, and agricultural residues. Energy crops do not appear very promising because of many competing uses for the land. With a growing population, selfsufficiency in food is the highest priority, so most available land will be used to grow food rather than energy crops. Although eucalyptus trees have been planted on semi-arid land and along highways, the Indian government has not officially slated any of them for use as energy crops; they were mainly planted for soil conservation and beautification reasons. ${ }^{12}$ Furthermore, urban sprawl, re-forestation, and other infrastructure needs all take precedence for land use in India.

Since the 1980s, numerous teams of researchers have worked with Chinese experts and officials from Yunnan Province to plan, evaluate, and implement biomass electricity projects. Yunnan is a good target for biomass projects because there are dry season power shortages, no cheap local resources and it has experience with reforestation. ${ }^{13}$ Currently, tree plantations are being established in Yunnan Province, and there are some plans to co-fire existing sugar mills with bagasse and wood. However, energy crops in most of China are also hindered by competing uses for the land which is exacerbated by random development planning. On a more informal level, rural areas of the country are using crop residues and organic waste for home heating and cooking. Biogas programs are also being implemented on small-scale plants, which are less than $5 \mathrm{~kW}$ and use small wood gasifiers and diesel engines.

\footnotetext{
${ }^{12}$ Personal communication with Tata Energy and Resources Institute, April 1997. Furthermore, enough trees have to be planted on a sustainable basis to make the economics of energy crop production favorable. October.

${ }^{13}$ Perlack, Robert D., Oak Ridge National Laboratory, 1993, "Biomass Energy Development in Developing Countries--presentation,"
} 


\subsubsection{Potential Applications of Biomass Power}

\section{Sugar and Pulp \& Paper Industries ${ }^{14}$}

The sugar and pulp and paper industries are obvious targets for biopower because their operations require electricity and they have a constant supply of "fuel" available at little or no cost. By effectively re-using the by-products of their daily activities they can improve the efficiency of their operations. This is even more pronounced in India and China because their mills are highly energy inefficient compared to the developed world, thus making them good first targets for the biopower developer.

As shown below for India, the apparent continuing growth in both of these industries suggests that India may have a steady resource base with which to power new biomass facilities. Cogeneration at sugar mills has been the most consistently successful biopower effort in India-it has, in fact, become commercially viable. ${ }^{15}$ The central government promotes this technology and two states are actively pursuing bagassefired power generation; sugar mills in the states of Tamil Nadu and Karnataka are beginning to build cogeneration plants to export power to the grid. As this technology is upgraded, markets for surplus power become available, and grid-connected cogeneration spreads to other states, the sugar industry could generate nearly $3,500 \mathrm{MW}$ of additional power, ${ }^{16}$ which is even greater than the projected technical potential for sugar mills shown in exhibit 2.3-5.

Energy inefficiencies at pulp and paper mills, however, may require many solutions. On average, the energy intensity at Indian mills is almost five times as large as that in industrialized countries and only 40 percent of them utilize cogeneration, compared to 100 percent in the industrialized world. ${ }^{17}$ It remains to be seen how direct the relationship between biomass power development and the growth in these industries will be, but provided the correlation is positive, India appears well positioned to take advantage of any synergies that may present themselves, especially in the sugar industry.

\section{India:}
Number of pulp \& paper mills:
(1985) 362
(1990) 535
(1993) 472
Sugar Production (000's tonnes):
(1990) 13,707
(1993) 11,660
(1995) 16,500

As shown below for China, there is little apparent recent growth in these two industries, so opportunities may not be as widespread as in India. However, there may be more potential than there appears, because the government has made increased bagasse-fired cogeneration one of its renewable energy goals. The Chinese do not consume sugar on a level at par with the rest of Asia, but sugar production has expanded from the east to the northwest and the southwest, and the country is interested in promoting further development of sugar crop production. On a per unit of output basis, China's pulp and paper industry is not as energy-intensive as India's, but it is almost 60 percent more intensive than Japan's. Its low energy efficiencies are attributed to outdated technology (most from the 1940s and 50s), the small scale of the enterprises, the inferior quality of raw materials, and the lack of energy recovery and reuse. ${ }^{18}$ By targeting

\footnotetext{
${ }^{14}$ US Department of Agriculture and Miller Freeman Publications, 1995, PPI's International Fact and Price Book.

${ }^{15}$ Tata Energy and Resources Institute, 1997, personal communication, April.

16" Opening the Market for Cogenerated Power in Tamil Nadu and Karnataka," 1997, Winrock International REEP Update.

${ }^{17}$ Ishiguro, M. and T. Akiyama, 1995, Energy Demand in Five Major Asian Developing Countries, World Bank Discussion Paper \#277, p. 80.

${ }^{18}$ Ishiguro, M. and T. Akiyama, 1995, p. 79.
} 
these industries, international developers can start to establish relationships for future joint ventures and gain experience in dealing with the country's governmental agencies.

\section{China:}

Number of pulp \& paper mills:

$$
\text { (1985) } 377
$$

(1990) 426

(1993) 426

Sugar Production (000's tonnes):

(1990) 6,765

(1993) 6,505

(1995) 6,700

For developers interested in tapping into these markets first, chapter 7 will discuss technological opportunities in the sugar and paper industries.

\section{Distributed Generation}

Distributed generation (DG) is a unique opportunity in India and China. Both countries have large rural populations that are not served by reliable electricity and the governments have made rural electrification a priority. The availability of a biofuel resource in rural areas makes off-grid biomass applications feasible. However, this may not be as promising as the data suggest. Cultural norms and decades of poverty have fostered industriousness. To most Indians, there is no "waste"; one man's waste is another man's resource. As a result, the availability of a steady fuel resource is the biggest barrier to implementing biomass projects in rural areas. For example, agricultural resources are used for compost and fertilizer and very little is disposed of. Some experts state that the maximum size unit that can be sustained with biomass resource in rural areas of India is between $100-200 \mathrm{~kW}$, but the high efficiency technologies are not yet viable at that scale. ${ }^{19}$ This, combined with the Indian subsidy structure which makes payment collection from agricultural consumers nearly impossible, makes rural DG systems better candidates for the country's government than for the international power developer. Although China does not have as extensive an agricultural subsidy structure, the lack of a steady supply of biomass resource and rural poverty are common themes. In their favor, however, DG systems avoid transmission lines, so they may offer opportunities for agro-industries that grid-connected power cannot. For further discussion, see chapter 7.

\section{Co-firing}

Co-firing is the co-combustion of different fuels in the same boiler. Biomass is a well-suited resource for co-firing with other solid fuels, primarily coal, due to general similarities in storage and handling requirements. A biomass co-firing retrofit in an existing coal boiler will require modifications or additions to fuel handling, storage, and feed systems, but these can be accomplished using commercially available equipment. Co-firing utilizing biomass has been successfully demonstrated and is currently practiced in the full range of coal boiler types including pulverized coal boilers, stokers, cyclones, and bubbling and circulating fluidized beds. It should be noted that co-firing is a replacement option for existing fuel capacity, and is not a capacity expansion option like repowering.

Atmospheric environmental benefits associated with using biomass resources to replace fossil fuels (primarily coal) include reductions in net emissions of greenhouse gases (carbon dioxide, $\mathrm{CO}_{2}$ ) and acid rain precursors (sulfur dioxide, $\mathrm{SO}_{2}$, and possibly nitrogen oxides, $\mathrm{NO}_{\mathrm{x}}$ ). Sulfur dioxide and net carbon emissions are reduced in proportion to the amount of heat input obtained from biomass. Coal used for power production in India is, on average, higher in sulfur than U.S. coal, on an energy content basis, ${ }^{20}$ so the sulfur reduction benefits associated with replacing coal with biomass in India will be greater. Coal in

\footnotetext{
${ }^{19}$ Tata Energy and Resources Institute, 1997, personal communication, April.

${ }^{20}$ U.S. Department of Energy, 1994, Foreign Markets for U.S. Clean Coal Technologies, DOE/FE-0317, May 2, p.3-35 and Office of Technology Assessment, 1992, Fueling Development: Energy Technologies for Developing Countries, OTA-E-516, pp.246.
} 
China is typically low in sulfur content, so China may not see the same incremental benefit of sulfur reduction. These benefits apply for all biomass power technology options, but there are additional benefits unique to co-firing. One of these is the small amount of capital investment required ( $\$ 300$ to $\$ 500$ per $\mathrm{kW}$ of biomass power, in the U.S.) relative to most other renewable power generation technologies. The low capital cost makes co-firing an attractive option for introducing renewable power into a power producer's generation mix.

Since coal is the primary fuel for electricity production in many countries, biomass co-firing has a large potential market. In India and China, coal is used for approximately 70 percent of electricity generation. ${ }^{21}$ Commercial trials in the U.S. have shown that, using the proper methods and in the appropriate situations (see Chapter 7 for details), co-firing biomass with coal can be achieved on a sustainable basis with minimal performance degradation on power plant and boiler systems with as much as 20 percent of the heat input obtained from biomass. Due primarily to biomass resource availability constraints and, to a smaller extent, performance concerns, a more common level of heat input from biomass in co-firing applications will be less than 10 percent.

In most U.S. power plants that have implemented biomass co-firing systems, reducing production costs has been the primary driver-the emissions reductions are viewed as a secondary benefit. Biomass co-firing installations are presently found in areas where the cost of coal is high relative to the cost of available biomass residues. Thus, the key to co-firing projects has been locating cheap, reliable supplies of biomass in quantities large enough to pay off the retrofit investment in an acceptable period of time (3 years or less). These residues are normally obtained from agricultural industries, urban waste, or forest product industries such as lumber, furniture, and pulp and paper. However, since residential and small industry use of biomass residues for heating and cooking is higher in China and India than in the U.S., ${ }^{22}$ competition for available residues is expected to be stiffer in these developing countries. Furthermore, due to high populations in both India and China, food production represents the most significant competition for fertile agricultural land-land which is also best suited to yielding economically competitive energy crops.

Hence, for co-firing and most other biopower opportunities, technology development, although important because of efficiency improvements, is much less of an issue than resource economics and availability. In co-firing applications, existing equipment with its inherent efficiency is used to convert biomass into electricity. Advanced technologies such as gasification in combination with gas turbines or fuel cells will have higher conversion efficiencies and may provide a solution for reducing the land requirements for a given amount of biopower capacity.

\section{Repowering}

Although "repowering" will be defined more thoroughly in an upcoming chapter, historically the term has referred to replacement of a boiler at an existing coal- or oil-fired power plant with a gas turbine.

Typically the retained equipment includes the steam turbine and much of the balance-of-plant equipment. As a result, the plant is usually converted to combined cycle operation using the gas turbine and retained steam generator to produce power. For countries like India and China that rely heavily on coal-fired generation, repowering offers a technically feasible means of addressing environmental and future generation demand issues. Repowering a coal-fired plant in the manner described above using a natural gas-fired combustion turbine, one might expect to triple the plant's capacity, reduce $\mathrm{SO}_{\mathrm{x}}$ emissions by

\footnotetext{
${ }^{21}$ U.S. Department of Energy, 1994, op. cit.

${ }^{22}$ Ibid., pp.247-8.
} 
nearly 100 percent, reduce $\mathrm{NO}_{\mathrm{X}}$ emissions by 75 percent, and increase efficiency by $15-30$ percent. However, in countries like India and China, using coal for power generation involves issues beyond lowering production costs. Using coal is related to complex social, political, and economic policy issues. Large-scale replacement of coal with natural gas or biomass is not likely to be initiated in the short term. Fortunately, there are many other repowering options that may be better suited to biomass in countries like India and China. Although these options do not afford such large efficiency, capacity, or environmental gains, they do provide for an incremental approach that may be more acceptable to prevailing political forces in these countries.

Unlike co-firing, repowering using biomass still requires considerable research and development. Assuming that a number of technology barriers can be overcome, biomass for repowering projects in India and China will become feasible. Beyond the augmentation of utility coal- or oil-fired boilers, biomass repowering project developers will be interested in industries already handling large volumes of biomass material (the pulp and paper industry and sugar industry, for example). Only limited information is available characterizing these industries, but with a combined total of nearly 900 pulp and paper mills, there is a large population of plants for which biomass repowering may be an option.

\section{Waste-to-Energy}

The definition of biomass power also includes combusting municipal solid waste (MSW) to generate electricity. Although there is public and political opposition to waste-to-energy (WTE) plants in the U.S., this is not necessarily the case in India and China. In fact, India's Union Minister for Urban and Parliamentary Affairs envisions a scenario where "social awareness and public concern (about the urban waste problem) should spur quick action to utilize the waste for generating wealth to the urban population." 23 WTE can address two problems: shortage of electricity and excessive urban and industrial solid waste.

Indian universities recently joined forces with their American counterparts to learn about technologies that can tackle these problems comprehensively. India's urban areas generate approximately 70,000 tonnes of MSW daily, much of it organic, and the universities are interested in converting this material into fertilizer and power. ${ }^{24}$ The countries' climatic and social conditions are ideal for this biotechnology and as in all nations with growing urban centers, MSW is ubiquitous. Furthermore, manual labor is abundant and inexpensive, so collection and separation of the waste would be cost-effective. A prototype is the Zabaleen project in Cairo, Egypt, where the traditional garbage collectors banded together and formed a "business" to address the city's solid waste problem.

Since public stigma of WTE is not as pronounced in developing countries, the municipality can focus its efforts on setting up the supporting infrastructure. It also has a good chance of educating people on the benefits of incorporating WTE as part of future electricity planning and comprehensive solid waste planning. Thus, an international developer should not overlook this aspect of biopower. It does not face the same hurdles as in the U.S. and the developer can actually play a role in expanding biopower beyond the conventionally accepted applications.

\footnotetext{
${ }^{23}$ The Hindu, 1996, September 24.

${ }^{24}$ Ibid.
} 


\subsection{INFRASTRUCTURE FINANCING ISSUES}

Although this report focuses on biomass power market opportunities, there are basic financing issues that are applicable to all international power projects. As discussed in this section, power developers need to understand traditional financing methods, trends in financing, risk management, and the future of power market development before embarking on a specific power project.

Infrastructure projects have taken a dominant role in international business and investment. Rapidly growing economies such as those in Asia and Latin America face a concurrent need to develop their power, water, telecommunications, road, and sanitation infrastructures. In most countries, however, internal efforts are inadequate to meet current and future infrastructure demands, so they have opened their markets to international private investment. The next several chapters will discuss the specific financial and business climates pertaining to power development in India and China.

\subsection{Traditional Financing Methods}

In most developing countries, governments currently provide or broker more than 90 percent of infrastructure financing. ${ }^{25}$ Tax revenues and government borrowings are the predominant source of infrastructure finance, so under this system, the government bears almost all project risks. This is because in most countries, the government is the most creditworthy entity and is able to borrow at the lowest rates, thus allowing them to build projects that otherwise may not be financially viable.

The problem with the current system, however, is that governments do not have unlimited access to resources; they have been hampered by tightened budgets, poor plant performance, and spotty pricing/billing records. As a result, they have been forced to rely on private financing (e.g., loans from financial institutions) and foreign funds from multilateral and bilateral sources to build and maintain infrastructure. However, despite its ubiquity, donor agency support has proven to be inadequate for infrastructure development. International donor policies often focus on funding new physical construction instead of long-term maintenance and improvement. Bilateral assistance requires that funds only be used to purchase equipment and services from specified countries. This requirement precludes international competition in procurement. Such issues have forced developing countries to seek alternative financing methods for expanding infrastructure development.

\subsection{Trends in Financing}

Although governments have used private financing to develop infrastructure projects, over the last several years, there has been a surge of international long-term private capital flowing to developing countries. A commonly used estimate is that an annual investment of $\$ 100$ billion is required for the power sectors in developing countries. ${ }^{26}$ Internal government financing will have to foot most of this bill, but the sheer magnitude of the investment requires that private financing play a significant role, especially in the near term. In the future, the power sectors in rapidly growing economies will have to be supported by a combination of public and private, domestic and international efforts.

The global power generation market is growing exponentially. Opportunities in Asia represent more than 77 percent of the current worldwide power activity, with this region accounting for about 91 percent of all

\footnotetext{
${ }^{25}$ World Bank, 1994, World Development Report 1994, p. 90.

${ }^{26}$ Dunkerley, Joy, 1995, "Financing the Energy Sector in Developing Countries," p. 930.
} 
proposed coal projects. ${ }^{27}$ Global competition for power development in the top markets is fierce-there are approximately 300 multinational players offering diverse strategies and business models. However, as shown in Exhibit 3.2-1, a handful of companies represent most of the world's independent power project activity. There is also a wide range of activity among these developers; the top 35 companies range in activity from AES at 4,771 MW of equity to Decker Energy at just $15 \mathrm{MW}$ of equity. ${ }^{28}$ This shows that even though the international independent power market is growing, a few select players still control most of the activity.

These companies have been successful because they have been able to provide creative solutions and competitive advantages. Some of the tactics include being $a(n)$ : early entrant; niche player; low-cost producer; solutions provider; or advantaged fuel supplier. ${ }^{29}$ For example, Enron Corporation has had success with two strategies: ${ }^{30}$ developing fuel delivery mechanisms such as pipelines and treatment facilities to secure fuel to the power plant, and building its reputation by developing smaller projects in the $100 \mathrm{MW}$ range which have a quicker turnaround time. Due to international market fluctuations, however, no one model has prevailed, so there is still room for new players and new approaches to enter the market.

\begin{tabular}{|c|c|c|}
\hline \multicolumn{3}{|c|}{$\begin{array}{l}\text { Top } 10 \text { Independent Power Developers of } 1996 \\
\text { (Rank, Company, MW of equity) }\end{array}$} \\
\hline 1) & AES Corp. & 4,771 \\
\hline 2) & Edison Mission Energy & 2,339 \\
\hline 3) & PowerGen & 1,776 \\
\hline 4) & National Power & 1,743 \\
\hline 5) & Powerfin (Tractebel) & 1,371 \\
\hline 6) & InterGen & 890 \\
\hline 7) & Electricity Generating Public Co. & 824 \\
\hline 8) & GE Capital & 582 \\
\hline 9) & Enron Development & 487 \\
\hline 10) & Calpine & 480 \\
\hline \multicolumn{3}{|c|}{ Source: Independent Energy, April 1997.} \\
\hline
\end{tabular}

EXHIBIT 3.2-1

\subsubsection{Independent Power Projects and Project Finance}

As countries began to allow direct private capital investment in infrastructure, a few pursued this option vigorously and transferred ownership of government-owned power facilities to the private sector. Most countries, however, (India, Philippines, and China, for example), took a less sweeping approach by encouraging privately financed independent power projects. For these governments, internal budgetary constraints, uncertainty regarding donor agency funding, and utility operational inefficiencies made international private financing more attractive. They believed that an increased private presence would not only provide financial resources, but also the financial and managerial discipline that was lacking in the public power sector. ${ }^{31}$ International private developers were also interested because they were tapping into a growing and potentially lucrative market and they were establishing a presence by providing an economically and socially beneficial product.

\footnotetext{
${ }^{27}$ Poirier, Jean-Louis, 1996, "Global Power: The Big Picture," in Proceedings from the Power-Gen '96 International Conference and Exhibition, Fiorida, December 4-6, p. 2. 
Most independent power projects were financed through nonrecourse financing, "project finance," where the equity and bond holders are repaid from the revenues and profits of the project itself, and not from the assets of the parent company. Project finance can also be in the form of limited-recourse financing, where some of the assets of the parent company may be used to repay the lenders. Conversely, in corporate finance, the lender is repaid based on the assets of the parent company, not just on the success or failure of one lone project. Because of its inherently higher risk, lenders involved in project finance require a higher rate of return. The share of equity in a typical project is usually around 25 to 30 percent and the remaining capital is borrowed from a variety of international sources, including commercial banks, infrastructure funds, equipment suppliers, multilateral development banks, and export credit agencies. Domestic investors include the business community, pension funds, local commercial banks, and insurance companies.

Since most of the power generating facilities in developing countries are publicly owned, most of the power generated by independent power producers (IPPs) is sold to a governmentowned power generator.

However, to attract more private investors, some countries are now allowing IPPs to sell power directly to large consumers or enter into joint ventures with domestic

\section{Recent Power Projects}

In India, the Tamil Nadu State Electricity Board (SEB) recently released a solicitation for $2,000 \mathrm{MW}$ of new generation facilities with a stipulation that the Board would buy the power under a Power Purchasing Agreement.

In India, the Bihar SEB instituted a policy that allows IPPs to enter into contracts to sell power to the SEB or directly to large power customers, where the IPPs would pay a fee to the SEB to wheel the power.

In China, the $100 \mathrm{MW}$ Qingjiu Hydro Project will be a joint venture with a local government-owned developer, and for two new projects in the Guangzhou province, electricity will be sold to either the local electric power bureau or industrial customers.

In China, the government of Huadu City, Guangdong Province set up a power shareholding company under which foreign participants could enter into joint ventures with one of three Chinese companies to build more than $300 \mathrm{MW}$ of coal-fired capacity.

entities. See Exhibit 3.2-2 for

a synopsis of some recent efforts. ${ }^{32}$

As these projects demonstrate, IPPs can supplement the host government's efforts. However, they can also be catalysts for power sector reform and improved performance. Developers often need guarantees from the host government before a power project gets off the ground. The government is thus an integral part of the process and becomes exposed to sophisticated financial instruments and modern technologies. As they infiltrate the power sector, IPPs can apply pressure for tariff reform. Private investment may make policy makers realize the true cost of subsidized electricity and encourage publicly owned utilities to change their tariff structure. Finally, developers usually incorporate the project's environmental impacts in their plans, especially if they receive support from development banks or export credit agencies, both of which require environmental impact assessments. The downside to project financed IPPs is that they involve an amalgamation of players, so risk allocation and negotiations can be very time-consuming.

${ }^{32}$ McGraw Hill, 1996, International Private Power Quarterly, Fourth Quarter. 


\subsubsection{Project Risk}

Infrastructure projects are unique in that most of these projects have long lives, are large and immobile, generate only local currency revenues, interact directly with government agencies, are vulnerable to regulatory changes, and have politically sensitive tariffs. ${ }^{33}$ Infrastructure development is also atypical because it addresses a social need, so it competes with other publicly beneficial projects for funding. As a result, power developers and investors doing business in developing countries often face a set of risks that they are unaccustomed to addressing.

Risks associated with developing country power projects include: market, regulatory, construction, operational, foreign exchange, and environmental risks. ${ }^{34}$ These are briefly discussed below. For the purposes of this report, technological risk will not be discussed.

- Market risk stems from the government's focus on meeting social needs over economic efficiency, which result in subsidies and tariff structures that do not reflect the true cost of production.

- Regulatory risk occurs when laws protecting investor and developers are lacking or in a state of flux and when regulatory and enforcement pathways are unclear.

- Construction risk occurs when project capital costs exceed estimates.

- Operational risk is based on fuel cost and availability (resource variability is a major concern for biomass residues).

- Foreign Exchange risk stems from the repatriation of profits, fluctuations in the exchange rate, and from the availability of foreign exchange to cover debt service and equity payments.

- Environmental risk is managing and mitigating the risk to the natural environment, such as violation of emission standards, site contamination, and resettling the indigenous population.

There are a variety of financial risk-mitigating options. One is the build-operate-transfer (BOT) model which has been effective in raising financing and allocating risks. In this model, the private developer builds the plant, operates it for an agreed-upon period, and at a pre-determined time transfers ownership to an in-country entity. Variations are the build-own-operate (BOO), the build-own-operate-transfer (BOOT), and the build-transfer-operate (BTO) models. These are often done through project financing.

Foreign investors can also enter a country's power sector in a relatively less risky manner through joint ventures. In these scenarios, the foreign developer forges a strategic partnership with a host-country entity, thereby allowing each to utilize the other's skills and experience from the outset. Local partners know the "channels" and can bring an understanding of the political, cultural, and business environment to the consortium. In addition, such links help the U.S. developer establish credibility and foster a larger relationship with the country. Joint ventures are becoming a popular and often necessary way to expedite project acceptance and reduce risk.

Risk can also be spread among countries. The U.S. Initiative on Joint Implementation (USIJI) is an example of inter-country partnerships. As part of the Framework Convention on Climate Change, USIJI is based on the idea that implementation of technologies that mitigate greenhouse gas emissions is cheaper in some countries than in others. Therefore, "more-expensive" countries could invest in "cheaper" ones and claim " $\mathrm{CO}_{2}$ credit" for those investments. ${ }^{35}$ This initiative was also intended to increase private sector

\footnotetext{
${ }^{33}$ Bond and Carter, 1995, "Financing Energy Projects," p. 969.

${ }^{34}$ Bond and Carter, 1995, "Financing Energy Projects," pp. 969-971.

${ }^{35}$ Center for Clean Air Policy, 1996, Joint Implementation Projects in Central and Eastern Europe, p. 2.
} 
investment in developing countries and assist in expansion of international markets for environmentally beneficial technologies.

Other risk reduction opportunities exist within the Overseas Private Investment Corporation (OPIC). OPIC provides a range of services to U.S. firms interested in investing in more than 140 countries. The continued existence of OPIC is a political question being considered by the current Congress. However, the services offered by OPIC are necessary if small- to mid-sized U.S. firms hope to compete in the international power market. Chapter 8 describes OPIC's services.

Despite the benefits of current efforts, long-term risk mitigation is possible only after a country's financial markets become more sophisticated. In the meantime, "specialized intermediaries" can act as catalysts for capital-market development. ${ }^{36}$ For example, India's Infrastructure Leasing and Financial Services Corporation and its Housing and Urban Development Corporation plan to consolidate securities from different projects and sell shares in the package to investors, much like a mutual fund. Mexico's infrastructure bank, BANOBRAS, guarantees that municipalities will pay for services provided by private water and sewerage projects, and it is trying to strengthen municipal finances by demanding better operational and financial performance as a condition of support.

To address the issue of limited capital faced by most developing countries, two types of infrastructure funds have emerged: government-sponsored funds and private funds. Governmentsponsored infrastructure development funds offer a more transitional solution by providing long-term finance until capital markets are more developed. Private funds diversify investor risk and are growing in number. They attract co-financing from private sources which allows for the leveraging of government resources or official development assistance and they create credit histories for "risky" borrowers. Examples of infrastructure funds are listed in Exhibit 3.2-3. ${ }^{37}$

All of these intermediary efforts are

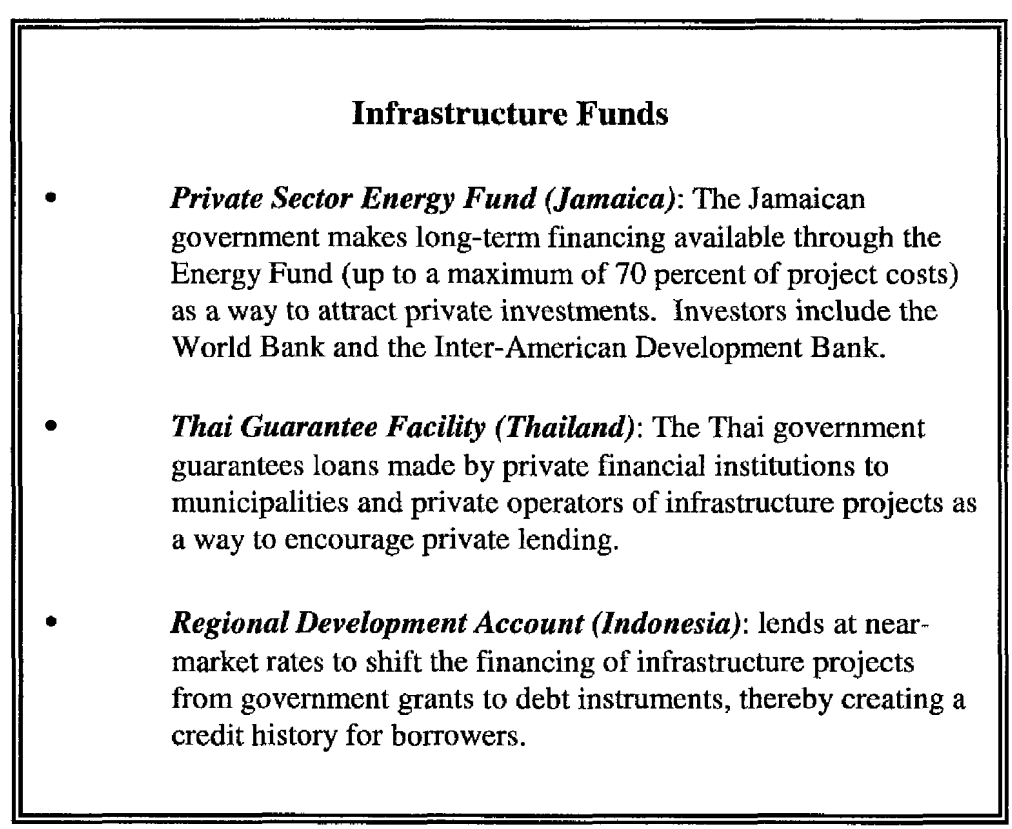

EXHIBIT 3.2-3 aimed at developing the domestic capital markets, because the markets must become sophisticated enough to act as conduits for infrastructure finance. Once that occurs, some risk is automatically reduced.

\footnotetext{
${ }^{36}$ World Bank, 1994, World Development Report 1994, p. 103.

${ }^{37}$ Ibid, p. 104.
} 


\subsubsection{Future of Power Market Development}

Although it has been incrementally successful in various countries, in the long term foreign investment alone cannot sustain a market as large as the power sector. The sheer size and maturity of its financing requirements are such that the bulk of investment must come from indigenous markets. To accomplish this, many experts believe that market principles should be introduced into infrastructure provision in developing countries. Market principles can be introduced after the country addresses two sets of policy constraints: structural and sectoral, as explained in Exhibits 3.2-4 and 3.2-5.

\section{Miscellaneous Issues in Power Market Development}

In the biggest markets, developers are experimenting with alternatives to traditional project finance. For projects in India and China, U.S. commercial banks have yet to be convinced that the IPP efforts are worth financing because very few of the projects undertaken in these countries have reached financial closure. ${ }^{38}$ Developers are thus finding ways to lower risks that raise the cost of capital. Examples are the acquisition of existing plants (i.e., privatizing them) or engaging in hybrid financing where a developer may establish a holding company for a portfolio of projects and raise funds through a debt issue or public stock offering. ${ }^{39}$ This approach gives the developer leverage to reach the more sophisticated corporate finance markets.

\begin{tabular}{||l||}
\hline Top 3 Issues in International \\
Private Power Development \\
1) \\
Need to secure a long-term power purchase \\
agreement (PPA) with the assurance that the contract \\
is enforceable \\
Need assurances on variable costs: \\
$*$ foreign exchange -- currency convertibility \\
and repatriation of profits \\
$*$ fuel -- reliable and credible fuel supply and \\
transportation \\
Financing arrangements \\
$*$ average debt/equity split is $75 \% / 25 \%$ \\
3) \\
Source: personal communication with a U.S. private power \\
developer, March 15, 1997.
\end{tabular}

The following items are also of importance to developers: the role of guarantees, corporate financing, and retail credit. Currently, most governments and/or donor agencies provide guarantees to make private power projects possible. However, effects on the government's ability to pay and its credit rating prevent the use of guarantees as a perennial solution. Guarantees are a transitional tool and cannot compensate for a flawed policy environment. Thus, governments are moving towards piece-meal approaches such as partial risk and partial credit guarantees. The goal is that, as the country moves towards reform, the importance of guarantees will decrease.

If a country implements the structural and sectoral initiatives, corporate financing should emerge as the most significant form of private capital used to meet energy sector needs. Unlike project financing, corporate financing uses the equity of the whole enterprise to raise debt in the market. As a result, risk is lowered so the cost of capital is lowered. This trend has been demonstrated recently, as some developers of private generation projects are putting their own balance sheets at risk to raise cheaper debt for projects. ${ }^{40}$

\footnotetext{
${ }^{38}$ Burr, Michael T., 1997, "Refocusing Finance," Independent Energy, March, pp. 14-16.

${ }^{39}$ Op. Cit.

${ }^{40}$ Jechoutek and Lamech, 1995, "New Directions in Electric Power Financing," pp. 949-950.
} 
Access to retail credit will help provide electricity to rural areas and the poor. Instead of using subsidies, the government should promote skills that allow local banks, financial institutions, and marketing agents to provide a range of credit instruments to rural and low-income consumers. ${ }^{41}$ Early evaluation results of the Grameen Bank in Bangladesh showed that the rural poor have a significantly lower loan default rate than other consumers in the country. Thus, a well-functioning credit system can go beyond infrastructure development by stimulating other savings and investment opportunities in previously neglected lowincome areas. Once that is accomplished and sustained, the rural population's income levels will rise and they can then afford to buy unsubsidized power and even attract power development in their areas.

${ }^{41}$ Ibid, p. 952. 


\section{EXHIBIT 3.2-4}

\begin{tabular}{|c|c|c|}
\hline Structural Initiative & Issue & \\
\hline \multirow[t]{4}{*}{$\begin{array}{l}\text { Fiscal and Pricing } \\
\text { Policy }\end{array}$} & 1) & $\begin{array}{l}\text { Electricity pricing must reflect the true cost of production and subsidies must } \\
\text { be eliminated }\end{array}$ \\
\hline & & $\begin{array}{l}\text { Although there are political and social reasons for subsidies, annual } \\
\text { subsidy payments for electric power consumers in developing } \\
\text { countries range to more than } \$ 100 \text { billion per year-approximately } \\
\text { equal to the annual investment needs. }\end{array}$ \\
\hline & 2) & Dividend requirement for state enterprises \\
\hline & & $\begin{array}{l}\text { Funds provided to public enterprises are not priced at their social } \\
\text { opportunity cost, so the state enterprises may make inappropriate } \\
\text { investment decisions; as a result, they may not have enough money to } \\
\text { make dividend payments viable. }\end{array}$ \\
\hline \multirow{8}{*}{$\begin{array}{l}\text { Domestic Capital } \\
\text { Market Development }\end{array}$} & 1) & The objectives of domestic capital market development are to: \\
\hline & & shift the burden of savings onto households \\
\hline & & shift energy sector financing to private financial markets \\
\hline & & balance the amount of external and domestic capital \\
\hline & 2) & The following initiatives could deepen the capital market: \\
\hline & & $\begin{array}{l}\text { promote the possibilities for private project developers to trade their } \\
\text { project debt and equity in the domestic capital market to minimize } \\
\text { risk of illiquidity }\end{array}$ \\
\hline & & $\begin{array}{l}\text { promote markets for domestic institutional investors (e.g., pension } \\
\text { funds) to buy energy securities }\end{array}$ \\
\hline & & $\begin{array}{l}\text { encourage the growth of lease financing institutions and markets; } \\
\text { leasing can be performed by manufacturers and non-bank institutions }\end{array}$ \\
\hline
\end{tabular}

EXHIBIT 3.2-5

\section{Sectoral Initiative}

$\underline{\text { Sector Regulation }}$

Unbundling of

Services and

Privatization

Standards and Codes for Energy Efficiency
Issue

1) Clear and predictable public regulation of the energy sector is essential to bolstering investor confidence and security

* Implementation is equally important, because only even-handed implementation over a sustained period of time can alter negative perceptions.

1) Private investors perceive a vertical monopoly as too risky

* $\quad$ Steps to unbundle the services provided by the public monopoly will make it possible to focus private financing on those areas where it has a competitive advantage.

* $\quad$ Allowing the developer to reach customers directly diversifies his market risk.

1) Use minimum performance standards for energy conversion equipment and building codes

* Albeit difficult, enforcement is vital and often more effective than instituting taxes.

Source: Jechoutek and Lamech, 1995, "New Directions in Electric Power Financing," Energy Policy, pp. $945-947$. 


\subsection{INDIA-ENVIRONMENT FOR BIOMASS PRIVATE POWER DEVELOPMENT}

Rapid economic growth has made adequate, reliable power highly sought-after in all parts of the country. Most power is generated by coal, a trend that will continue into the future. However, the environmental damage associated with extensive coal use has led the government to experiment with renewable sources of energy, in both on- and off-grid applications. In general, India offers a strong environment for renewable power because the central government has tangibly supported it. The government-established Ministry of Nonconventional Energy Sources actively promotes renewable power and policies have been put in place that specifically incentivize renewable power development. To date, hydro, wind, and bagasse-fired cogeneration at sugar mills have been the most successful renewable power efforts.

In addition to activity at sugar mills, biopower has potential in a variety of other applications that are unique to countries such as India. Providing power to rural residents is a priority for the Indian government and biopower is considered a good answer to rural power needs. However, as explained in the next section, the agricultural subsidy structure prevents an international power developer from realizing a return on his investment. Thus, traditional rural electrification is a better target for the Indian

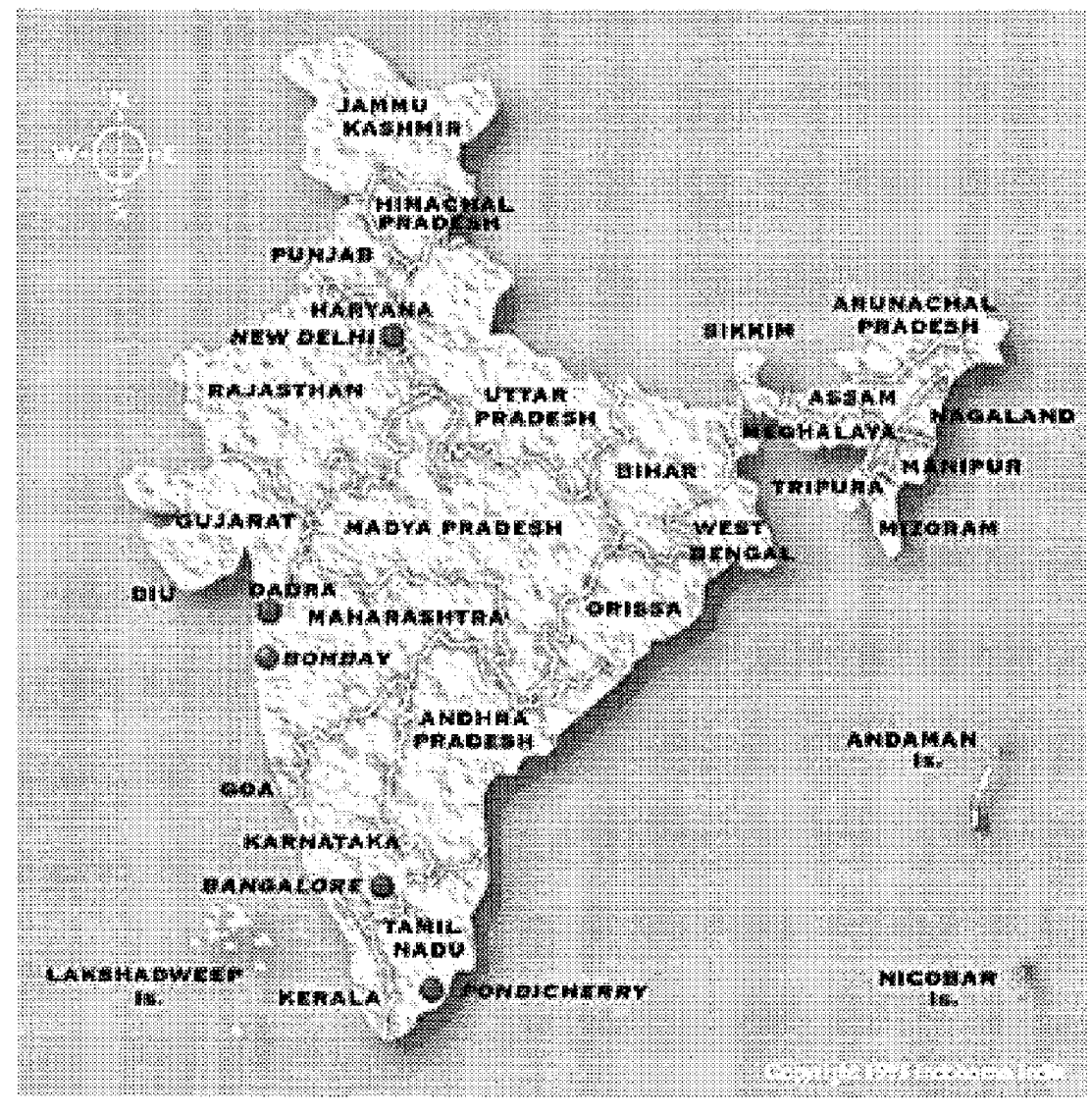
government. A better rural target for biopower in India would be off-grid industrial or commercial applications; there are several small-scale factories and mills in rural parts of the country. Biopower can help improve efficiency in the pulp and paper industry. Repowering aged coal plants and co-firing with biomass can help to improve industrial efficiency and reduce environmental emissions. Furthermore, the urban waste problem can be mitigated by waste to energy projects, which do not suffer from the same stigma as in the U.S.

However, despite this range of opportunities, biopower has not expanded to the degree expected. The main hurdles to biomass power development are not a lack of tangible, institutional interest, but the opportunity cost of the residues, the dominance of coal and other renewables such as hydro and wind, an historical subsidy structure, and a financially troubled power sector that controls most of the power supply. Thus, actual project development can be marred by uncertainties, delays, and a need for more unique approaches. However, the sheer size of India's electric capacity needs, a large agrarian economy, environmental concerns, the urban MSW problem, and industrial inefficiencies offer a diverse market for innovative international biopower developers.

This chapter discusses India's electric power industry, electricity tariffs, indigenous fuels that compete with biomass, the economic and political climate, energy and environmental policy, and the investment 
climate. To provide the international developer with a snapshot of the actual climate in India, the remainder of this chapter outlines the government approval requirements, lists renewable energy projects currently in development, describes recent power project solicitations, and provides a list of companies currently engaged in projects in India.

\subsection{Electric Power Industry}

The Indian power sector has traditionally been almost exclusively a public sector monopoly. State Electricity Boards (SEBs) account for 62 percent of the country's installed generating capacity. Along with the central government utilities, SEBs account for 96 percent of the electric power generated in India. The remaining 4 percent is supplied by five major private utilities. Other players in the power sector include: five regional electricity boards; thirteen municipal utilities that generate power under license from state governments; and thirty cooperatives that distribute electricity in rural areas.

Despite their dominance in the power industry, the public utilities are not as financially healthy or efficient as the private companies. A vast subsidy structure and poor operations and management have weakened the SEBs; taken together, the SEBs "may be the most ruinously inefficient public utilities in the world." 42 Because of their huge impact on the health of the SEBs, a brief discussion of the subsidy structures is warranted. ${ }^{43}$

More than 70 percent of India's citizens live in rural areas, often at poverty levels. In an attempt to promote rural development, the Indian SEBs have historically subsidized the agricultural sector. Unfortunately, this has led them into poor financial health and a deteriorating performance record. The effective subsidy is the amount of revenue lost by the SEBs because they are selling at less than the average cost to this sector. In 1992-93, the effective subsidy to agricultural consumers was $\$ 2.06$ billion which jumped to $\$ 2.9$ billion by $1994-95 .{ }^{44}$ In 1996 , the SEBs are expected to run up losses of $\$ 2.2$ billion. To compensate for this subsidy, the SEBs engage in cross-subsidization-they charge a higher price to their industrial and commercial customers to compensate for the lower price they charge to the agricultural customers. This practice is not uncommon, and countries incorporate it to different degrees.

However, the problem in India is that revenues from other sources do not compensate for the loss due to the subsidy policy. Agricultural customers purchase nearly 30 percent of the country's total electricity sales, but they provide only 4-5 percent of the electricity revenue; even with cross-subsidization and additional state financial support, the SEBs still had to absorb more than 55 percent of the subsidy $\operatorname{cost}^{45}$ The SEB cannot continue to raise the industrial/commercial tariffs, because of the potential negative effect on the economy. Already, some industrial customers are moving away from the grids and building cheaper

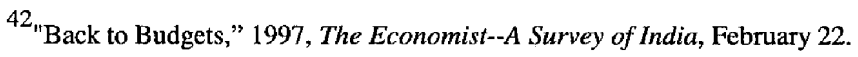

${ }^{43}$ For a more complete discussion, see Antares Group, Inc., 1996, Comparison of Large Central and Small Decentralized Power Generation in India, prepared for the USDOE and the National Renewable Energy Laboratory, December 15.

${ }^{44}$ GOI Planning Commission, 1995, p. 125.

${ }^{45}$ Ibid.
} 
and more reliable captive plants. This further hurts the SEBs because with each transfer to captive power, they are losing a valuable source of revenue. The agricultural subsidies and their effect on other power consumers have left the SEBs without enough money to honor current financial obligations, maintain existing facilities, or expand infrastructure, all of which make international developers reluctant to do business with them.

The SEBs' financial situation, continuing power shortages, T\&D losses exceeding 18 percent, and the inability of the SEBs and the central utilities to meet rising demand, have compelled the Indian Ministry of Power to amend electricity legislation to allow private companies to install their own capacity and/or distribute electricity as licensees of the SEBs. In the booming southern city of Bangalore, industry was experiencing a power allowance cut by as much as 70 percent and some companies even resorted to working by candlelight so they could use all available electricity to run their computers. ${ }^{46}$ To avoid the SEBs, such companies either rely on small generators or they build their own power plants. Ironically, states with large rural areas and hence, more biopower potential, are also the ones with the most financially constrained SEBs because of the high proportion of subsidized agricultural consumers. These SEBs will have the hardest time attracting international power developers because they cannot offer payment guarantees. Some states such as Orissa have a smaller proportion of agricultural customers relative to other Indian states, ${ }^{47}$ so they are able to take a cue from the World Bank and are undertaking restructuring efforts to financially strengthen their electricity boards and attract foreign investment.

\subsection{Electricity Tariffs}

Average Tariffs, by Sector $(1994-\mathrm{c} / \mathrm{kWh})$

Industrial/Commercial: $3.0-5.0$

Residential: $2.0-4.0$

Agricultural: 0.01-1.9
India's sectoral electricity consumption does not follow the pattern typical of an industrialized nation. While the largest consumer is the industrial sector at 36 percent, the agricultural sector is second at 29 percent, followed by the residential at 17 percent, commercial at 4 percent and others at 15 percent. ${ }^{48}$ In most developed countries, the agricultural sector does not represent such a large portion of total electricity sales. As described earlier, meshing a social agenda with the supply of power is one of the unique aspects of India's electricity market.

The SEBs' strained financial situation is primarily a function of their pricing policies. States usually charge higher prices to their commercial and industrial customers, who in turn subsidize the residential and agricultural customers. This pricing structure generates less revenue than the state needs to supply the electricity. Although most states have similar cross-subsidy structures, policies and incentives vary from state to state, adding to the complexity of private power development.

Agricultural power subsidies are extremely sensitive politically. Although a recent attempt to raise prices in the state of Haryana resulted in riots, the government is setting up boards to draft clear, understandable statewide rate structures. This move is fueled by international agencies' decisions to link their loans to transparent, cost-of-service power pricing.

\footnotetext{
${ }^{46}$ Cox, Kathleen, 1996, “A Prayer to Ganesha,” World Business, July/August, pp. 30-35.

Orissa is a unique case because agricultural consumers only make up $15 \%$ of their total sales, compared to $30-40 \%$ in most states. Thus it has a better chance of maintaining subsidies by only modestly increasing non-agricultural tariffs. As a result, its restructuring approach may not be applicable to other states in the country.

${ }^{48}$ GOI Planning Commission, 1995, Working of State Electricity Boards and Electricity Departments, p. 68.
} 
The country's average electricity tariff in 1994 was $3.2 \mathrm{c} / \mathrm{kWh}$. State-wide averages range from a low of $0.01 \mathrm{c} / \mathrm{kWh}$ in the northern state of Jammu \& Kashmir to a high of $0.05 \mathrm{c} / \mathrm{kWh}$ in Delhi district. ${ }^{49}$ As explained in section 4.1, the agricultural sector receives the greatest benefit. The danger of such a low average tariff is that a developer may not be able to charge a rate that covers his cost of production. In the case of newer technologies such as biomass, the costs of production may be even higher.

\subsection{Competing Fuels}

Biomass in India will have to compete with abundant fossil fuel reserves and their dominance in the fuel generation mix. Nearly 76 percent of the country's installed generation capacity is from fossil fuels (predominantly coal); 22 percent is from hydro, 2 percent is from nuclear, and 0.1 percent is from other renewables. The advantage that biomass brings is that it is an indigenous resource, so the government can then save the more valuable fuels for export, thus increasing its foreign currency reserves. Because of such strong competition from other fuels, this section first lists the fossil reserves in India and then concludes with a description of its coal industry.

\subsubsection{Reserves $^{50}$}

Coal: $\quad 125$ billion tonnes minable coal

Oil: $\quad 5.8$ billion barrels

Natural gas: 720 billion cubic meters $(\mathrm{bcm})$

Despite the large reserves of natural gas, the country is still constrained by the lack of gas infrastructure. However, India is interested in expanding its use of oil and natural gas. The Petroleum and Natural Gas Ministry set up a working group to speed up the process of importing liquefied natural gas and the government is planning to build new ports and pipelines to handle the gas.

\subsubsection{Coal}

With an annual production of more than 200 million tons, India ranks third in coal production after China and the U.S. ${ }^{51}$ Coal India Limited is one of the largest employers in the world with around 646,000 employees and miners, and it contributes more than 90 percent of the total coal produced in the nation. ${ }^{52}$ Coal is predominantly used by power utilities, which account for more than 60 percent of India's total consumption. ${ }^{53}$ Despite high production levels and generally low quality, demand for coal in India exceeds supply. Transportation problems exacerbate the shortages because although 67 percent of all coal produced is transported by rail, the system is strained and operating at capacity saturated levels. ${ }^{54}$

However, abundant reserves and a government-set minemouth price will maintain coal's dominant position in the Indian power sector. Coal offers a historical presence, synergism with an extensive transportation

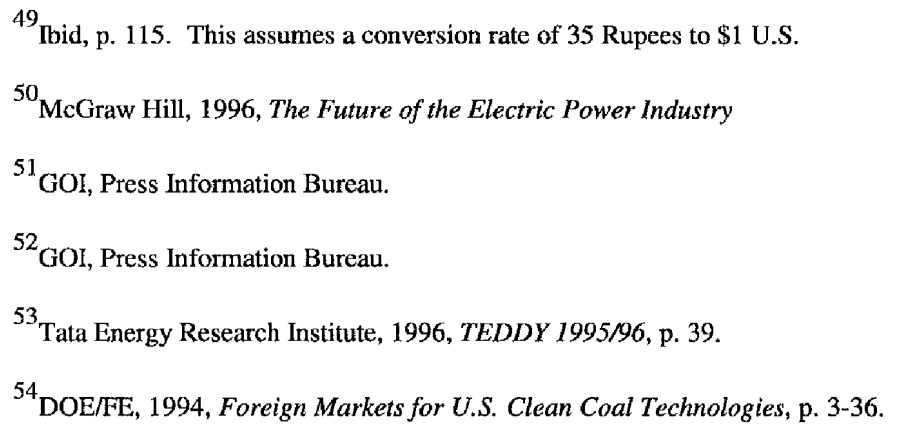


infrastructure, and a substantial national employment impact that other fuels cannot claim.

Coal is also protected as an industry because of India's labor policies. Large firms face more demanding requirements protecting their workers. For example, a firm employing more than 100 people cannot terminate an employee unless it first obtains permission from the state government. ${ }^{55}$ Workers are also not only guaranteed lifetime employment, but employment in perpetuity; after their deaths, their jobs go to relatives. ${ }^{56}$ Since the coal industry employs so many people, the workers have grounds for protest if their jobs are displaced. This presents a barrier to closing existing coal facilities or building new facilities that use a fuel other than coal, such as biomass.
Coal India Limited (CILtd.) extended 3 options to private power developers to secure a coal supply:

1) They can buy coal directly from CILtd., but prices are usually high

2) They can pay $\$ 100$ million to purchase the development rights to a mine that will be operated by CILtd., but output will be dedicated solely to the developer's power plant

3) They can purchase a mine directly

source: McGraw Hill, 1996, International Private Power Quarterly.

\subsection{Economic Climate}

Prior to India's economic liberalization in 1991, India was essentially a closed economy. Government officials defended this stance by saying that economic growth in a poor country faced a unique set of issues and eradication of poverty and improved education were more pressing concerns. However, this policy approach did not dramatically improve standards of living or education. In fact, it actually hampered current growth efforts because the economy does not benefit from the government's role as catalyst in certain key areas. ${ }^{57}$

True competition and open trade can spur innovation, improved quality, lower prices, greater profits for businesses, increased employment, and more tax revenue for the government. The government can then use this new revenue to institute more targeted social policies, because macro-level policies do not always reach the poor. Economists believe that the country has the necessary physical and human resources and work ethic to realize growth rates approaching those of the "tiger" economies of Southeast Asia. ${ }^{58}$ By moving away from the old policies and sustaining high economic growth rates instead, the government has a better chance of reducing poverty.

Despite the belief that it is not reaching its full potential, since opening its doors to the global market, India is considered one of the world's most promising economies, averaging a 7 percent annual growth rate for the past few years. ${ }^{59}$ This economic liberalization fueled a growing demand for electricity generation to

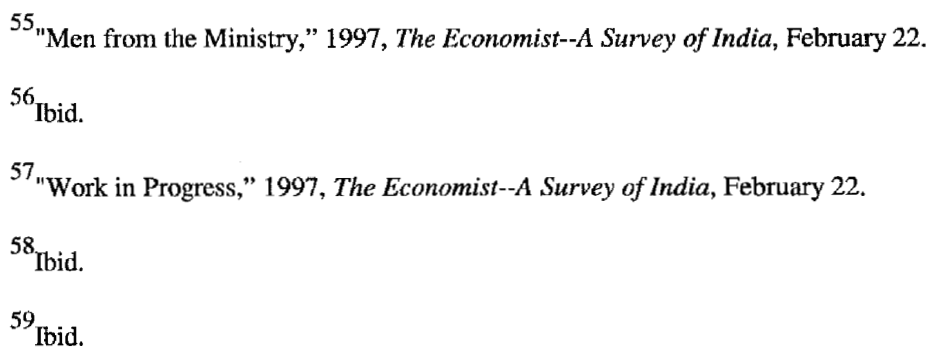


meet the power needs of industry, the burgeoning middle class, and the rural areas. India is projected to become the world's most populous nation by 2025 and its urban middle class, which currently exceeds 250 million, is nearly as large as the entire U.S. population. This group is significantly impacting the consumer demand for electricity, because they are purchasing refrigerators, televisions, and other appliances at unprecedented rates.

The government understands, however, that the future demand for electricity cannot be met by the SEBs and central utilities alone. According to DOE's International Energy Outlook, electricity demand is expected to grow by 4.6 percent annually after the year 2000 . The nation's rate of economic growth is expected to be sustainable as long as the proper infrastructure is in place. The nation's inability to meet rising power demand had led to peak capacity shortages ranging from 9 to as much as 35 percent regionally. ${ }^{60}$ In addition, like China, most of India's population is rural and

rural electrification efforts have been successful; by 1995, 85 percent of the villages had some access to electricity. ${ }^{61}$ To address all of these needs, the government plans to more than triple its present installed generating capacity by the year $2020 .^{62}$

\section{$\underline{\text { General Economic Indicators }}^{63}$}

GDP (1995/96):

Real GDP growth rate (1995/96):

Inflation rate (1995/96):

Foreign reserves (1997):

Official Development Assistance receipts (1993):

ODA disbursements as \% of GNP (1993):

Percentage of total current revenue (1993) --

Tax revenue from income, profit, capital gains:

Tax revenue from social security:

Tax revenue from goods \& services:

Tax revenue from international trade

$\&$ transactions:

Other tax revenue:

Non-tax revenue:
"There is sufficient pressure of modern industrialization on Indian thought and life."

-- John Kenneth Galbraith, former U.S. Ambassador to India

source: Washington Post Bookworld, 4/20/97, p.3

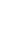

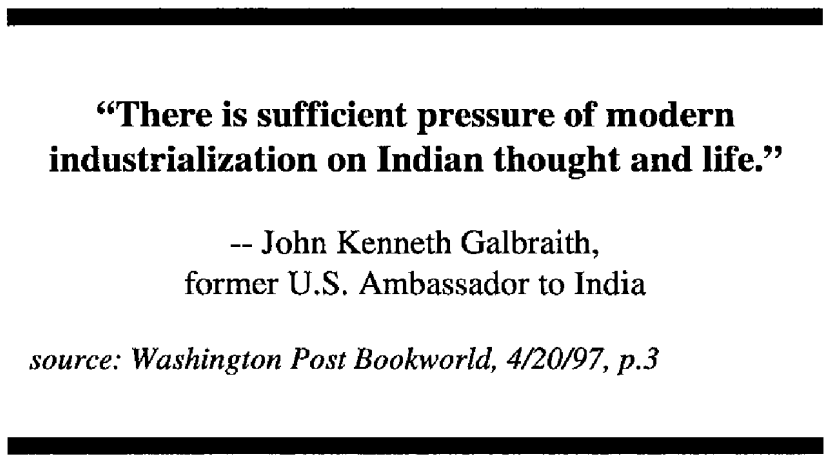

$\begin{array}{ll}\text { Tax revenue from income, profit, capital gains: } & 18.7 \% \\ \text { Tax revenue from social security: } & 0 \\ \text { Tax revenue from goods \& services: } & 32.1 \% \\ \text { Tax revenue from international trade } & \\ \text { \& transactions: } & 24.9 \% \\ \text { Other tax revenue: } & 0.4 \% \\ \text { Non-tax revenue: } & 23.9 \%\end{array}$

\author{
325.5 billion U.S.\$ \\ $7.0 \%$ \\ $10.3 \%$ \\ $\$ 20.2$ billion \\ 1.5 billion U.S. $\$$ \\ $0.6 \%$
}

$18.7 \%$

$32.1 \%$

$0.4 \%$

$23.9 \%$

\footnotetext{
${ }^{60}$ McGraw Hill, 1996, International Private Power Quarterly, Fourth Quarter, p. 125.

${ }^{61}$ Tata Energy Research Institute, 1996, TEDDY 1995/96, p. 72. According to the government's current definition, a village is considered electrified if one or more households have this service.

${ }^{62}$ McGraw Hill, 1996, International Private Power Quarterly, Fourth Quarter.

${ }^{63}$ World Bank, 1995, World Data 1995 CD-ROM and The Economist Intelligence Unit, 1997.
} 
$\underline{\text { Major Industries }}$

$\begin{array}{lll}\text { cement } & \text { machinery } & \text { steel } \\ \text { chemicals } & \text { mining } & \text { textiles } \\ \text { food processing } & \text { petroleum } & \text { transportation equipment }\end{array}$

$\underline{\text { Trade }}$

Major Trading Partners: Major Export Products:

Major Import Products:
Russia, U.S., Japan, UK, Germany, Italy, Belgium

Gems and jewelry, engineering goods, clothing, cotton textiles, iron ore, leather, chemicals

Petroleum and related products, machinery, iron and steel, chemicals, edible oils, fertilizers

\subsection{Political Climate}

The Congress Party, which has ruled India almost continuously since independence in 1947, was voted out of office in May 1996. A.B. Vajpayee, of the nationalist BJP party was sworn in as prime minister, but his administration lasted only a few weeks. He was replaced in June 1996 by H.D. Deve Gowda of the United Front coalition. As India's first coalition government, the United Front was an alliance of 13 parties with allegiances ranging from socialist to free market. After Mr. Deve Gowda took office, U.S. investors were not clamoring to enter India due to the slow pace of reform; they were waiting until he delivered on his promises to remove investment hurdles and accelerate deregulation. ${ }^{64}$

This proved prudent since the Deve Gowda administration did not last very long. On April 11, 1997, the Prime Minister resigned after losing a parliamentary confidence vote. The Congress Party withdrew its support of the United Front and demanded Gowda's resignation. ${ }^{65}$ On April 20, Foreign Minister Gujral became the new Prime Minister, the fourth one in less than a year. This recent occurrence underscores political instability in the world's largest democracy, which is threatened by comparably powerful liberal, nationalistic, socialist, and religious-based political groups. Despite the government's commitment to economic liberalization, relatively peaceful transfers of power, and its ability to prevent chaos in the midst of constant change, the fragmented and fluctuating nature of Indian politics and subsequent reforms increases the risk of doing business in this country.

\subsection{Environmental and Energy Policy}

This section discusses India's environmental and energy policies. They are comprehensive and farreaching, but as is the case in most developing countries, lax enforcement of these regulations is the paramount issue. The Indian government has set goals for renewable energy, but its specific policies pertaining to biomass were not available at the time of this report.

\subsubsection{Environmental Policy}

India's modern environmental philosophy centers around globalization and equity. With a growing emphasis on sustainable development, countries are realizing that their actions have far-reaching

\footnotetext{
${ }^{64}$ Karp, Jonathan, 1997, "Frustrated U.S. Investors are Turning Cold on India," The Wall Street Journal, February 19, p. A12.

${ }^{65}$ Guruswamy, Krishnan, The Associated Press, "India's Government Must Resign," 1997, April 11.
} 
implications. In such a global society, the members are beneficiaries of both state and international law, where the international law sometimes takes precedence. The general consensus is that underdevelopment in countries like India was a byproduct of the imperial colonies' development. ${ }^{66}$ Developing countries are, therefore, insisting on the freedom to find their own balance of sustainability between the environment and development. India's environmental regulations are an example of a developing country's attempt to find this harmony.

The Indian Constitution was amended in 1976 to include Article 48 which obliges the State to "endeavor to protect and improve the environment and to safeguard the forests and wildlife of the country," and Article 51 which imposes a duty on every Indian citizen to "protect and improve the natural environment including forests, lakes, rivers and wildlife, and to have compassion for living creatures." ${ }^{, 67}$ Appendix 1 lists the India's main environmental legislative acts.

In addition to the main regulations, the Indian government declared several policy initiatives: The National Forest Policy (1988); National Wild Life Action Plan; Forest (Conservation) Act (1988); Policy Statement for the Abatement of Pollution (1992); National Conservation Strategy and Policy Statement on Environment and Development (1992); and miscellaneous initiatives that include the cleaning of rivers, urban housing, land use, and recycling of wastes. ${ }^{68}$ Power systems using biomass are one way of combining the twin objectives of environmental protection and development.

Environmental standards for power projects could become stricter because in December 1996, the World Bank approved a $\$ 50$ million loan designed to strengthen monitoring and compliance with the laws. Furthermore, public awareness and support of environmental measures and the visibility of "green" groups has been growing. ${ }^{69}$ The risk, therefore, is not that the regulations are lax, but that enforcement is negligible or inconsistent at best.

\subsubsection{Energy Policy}

The government's energy strategies have focused on energy scarcity, energy conservation, and replacing oil with coal. Broadly speaking, its objectives are to: ${ }^{70}$

1. Reduce dependence on energy imports by devoting one-third of total government plan outlays to the development of indigenous energy resources

2. Allocate energy equitably, to ensure the equitable development of all regions in India and to safeguard the basic needs of the poor

3. Control energy industries, to provide energy to the industrial sector and other sectors at low prices.

Biomass-based DG systems can help support these policies. Biomass is an indigenous resource (objective 1 ), energy would be allocated equitably, and to the extent that the government's rural electrification

\footnotetext{
${ }^{66}$ Pathak, R.S., "International Trade and Environmental Development: A View from India," p.5.

${ }^{67}$ Pathak, R.S., p.2.

${ }^{68}$ Pathak, R.S., p.4.

${ }^{69}$ McGraw Hill, 1997, International Private Power Quarterly, First Quarter, p. 136.

${ }^{70}$ Ishiguro and Akiyama, 1995, Energy Demand in Five Major Asian Developing Countries: Structure and Prospects, World Bank Discussion Paper \#277, World Bank: Washington, DC, pp.33-4.
} 
program successfully promotes economic development, the basic needs of the poor would be served (objective 2). Successful biomass-based rural electrification (undertaken by the government) can help reduce agricultural subsidies which can then allow the SEBs to lower their industrial customers' electricity rates (objective 3).

The government's energy pricing policies are considered to be a primary obstacle to improving energy efficiency in India. Their pricing rules include: 1 ) cost-plus pricing, an administered pricing system that offers little incentive to improve energy efficiency; 2) retention pricing system, where the government allows enterprises to achieve a financial rate of return of 12 percent after tax; through this cross-subsidy system, the government collects taxes from profitable enterprises and subsidizes high-cost enterprises; and 3) social price subsidies to promote rural electrification, which has been accompanied by low tariffs and poor collection of payments from rural households. $^{71}$ These pricing policies and incentives can vary from state to state. For example, Karnataka state offers a five-year electricity tax exemption for captive use, whereas the state of Uttar Pradesh does not offer any electricity tax exemptions. ${ }^{72}$ Understanding the variety of institutional structures across jurisdictions is an important aspect of successful private power project development in India.

\section{$\underline{\text { Renewable Energy Policy }}$}

The government's Ministry of Nonconventional Energy Sources set a long-term goal of installing 16-27 GW of renewable power by 2015, accounting for 8-12 percent of power generating capacity. ${ }^{73}$ This includes bagasse cogeneration, small hydro, wind, non-cogen biomass, and solar technologies. To increase the financing for renewable energy, the government set up the Indian Renewable Energy Development Agency Limited (IREDA) to offer financing to manufacturers and project developers. The government also implemented fiscal incentives to encourage private-sector renewable energy investment such as 100 percent depreciation in the first year (see section 4.7.1).

\footnotetext{
${ }^{71}$ Ibid, pp.35-6.

${ }^{72}$ NBIA, 1995, Bagasse-Based Cogeneration in India: A Market Primer for U. S. Companies, p.10.

${ }^{73}$ The World Bank, 1996, China: Renewable Energy for Electric Power, September 11, p. 43.
} 


\subsection{Investment Climate}

In general, India is open to foreign investment; the country's government views it as a quick way to stimulate economic development. Since opening its markets in 1991, the government has allowed a multitude of companies to become involved with the nation's economic growth and huge infrastructure needs. However, the reforms aimed at accelerating economic growth by inviting foreign investment repudiate the traditional Indian motive of self-reliance. This conflict has posed problems for foreign investors in general, but for the power sector in particular because of its massive, short-term requirements and inconsistent investment climate.

The business hurdles for power generation are latent and endemic. Inefficiencies and business practices that would be considered unacceptable by western standards are locally accepted as routine. For example, inducements may be required to expedite agency approval and project development ${ }^{74}$ and massive agricultural subsidies have become a part of the rural psyche. Foreign investors and power developers, therefore, face hurdles that are cultural, institutional, and policy-based, often surrounding a social agenda that takes precedence over economic efficiency.

The following list ${ }^{75}$ of pros and cons provides an overview of the business and investment climate for foreign company power development in India. As evident from these lists, private power and renewable energy in particular are supported and promoted by the central government, but the inefficiencies of the states' power supply systems and subsidy structures force developers to proceed with caution. The items underlined specifically relate to renewable power.

\subsection{Pros}

- $\quad$ Renewable energy projects entitled to 100 percent depreciation in first year

- $\quad$ Full exemption from excise duties and general sales tax in most states; partial or full exemption from custom duties (Stirling engines and major wind turbines are fully exempt)

- The states of Maharashtra, Tamil Nadu, Karnataka, Uttar Pradesh, Madhya Pradesh, and Punjab offer a variety of policies and incentives for private cogeneration in their sugar sectors. Examples are allowing third party sales and electricity tax exemptions for captive use.

- $\quad \underline{\text { In 1994, India signed } 25 \text { agreements with U.S. companies to develop non-conventional }}$ technology.

- Formation of Indian-U.S. subcommission on sustainable energy development

- $\quad \$ 145$ million World Bank starter loan available for renewable energy project funding

- $\quad$ Government promoting development of bagasse-fired cogeneration

- The Ministry of Power proposed liberalized norms for setting up captive and cogeneration power projects; developers are allowed to sell surplus power to the grid.

- Government offers 16 percent ROR if plant load factor is $>=68.5$ percent; this ROR is based on a two-tier tariff system designed by the government to attract private developers, where one part covers the fixed capacity costs and the other covers the variable costs.

- $\quad$ Full repatriation of profits

- New projects entitled to a 5-year tax holiday

\footnotetext{
${ }^{74}$ Personal communication with businessmen and researchers who have worked in developing countries.

${ }^{75}$ Unless otherwise stated, this information was obtained from : McGraw Hill, 1997 \& 1996, International Private Power Quarterly.
} 
- $\quad$ Private enterprises are allowed a debt-to-equity ratio of 4 to 1 and up to 100 percent foreign equity participation is allowed. ${ }^{76}$

- Government announced intention to phase out electric power subsidies.

- Indian infrastructure development companies can sell up to 51percent of total equity to foreign entities.

- Exchange rates are still partially under government control, but they could be lifted over the next 12-18 months.

- Government decided to allow capital equipment used in electricity generating projects to be given "deemed export status," which gives the equipment manufacturer an offset for duties and taxes.

- Government cap on use of Indian resources of 40 percent of project cost, to maximize foreign investment. $^{77}$

- Projects less than $25 \mathrm{MW}$ or with a total cost of less than $\$ 285$ million are exempted from central government clearances; clearances are only needed at the state level.

- Ministry of Power is preparing a model PPA for future negotiations between IPPs and state governments.

- Alternatives to counter guarantees are being considered, such as having Indian financial institutions guarantee payments and part of the foreign debt.

- Some states, such as Orissa and Haryana, are restructuring their electric power sectors to improve efficiency.

- India opened its $\$ 36$ billion government securities markets to registered foreign institutional investors, who were allowed to invest in private sector debt instruments but were previously barred from investing in sovereign debt. ${ }^{78}$

- A growing consumer class that is becoming increasingly business savvy is demanding more interaction with the international business community.

- $\quad$ Overall country credit rating: GOOD ${ }^{79}$

\subsubsection{Cons}

- $\quad$ SEBs in poor financial health due to pricing policies/subsidies:

SEBs also run distribution networks

$\checkmark \quad$ Private developers cannot rely on the SEBs to pay them

$\triangle \quad$ Private developers cannot count on the soundness of state government guarantees of SEB liabilities

- Subsidies vary from state to state.

- The central government is no longer issuing direct counter guarantees to IPP developers; ${ }^{80}$ developers can obtain guarantees from the state government that cover one year's worth of payment. If that payment method does not work, then the central government may step in. The central government does not want to directly participate in the process.

\footnotetext{
${ }^{76}$ Power Tech Associates, P.C., 1992, Definitional Mission to India Regarding Private Power Projects, Findings and Recommendations, December, pp. 3-3 - 3-4.

${ }^{77}$ Ganguli, B., 1995, “India's Private Power Plan," Independent Energy, January.

78 "India Unleashes Securities Mart," 1997, The Wall Street Journal, January 31, p. A14.

${ }^{79}$ Rating derived from a U.S. credit agency's risk assessment, based on analysis of economic, political, and social indicators that assess such issues as: ability of country to generate sufficient foreign exchange; willingness to create favorable climate for trade and foreign investment; and resilience of economy to withstand domestic and external shocks. Range of credit ratings: excellent, very good, good, low, very low.

${ }^{80}$ Recent exceptions are the Dabhol and Ib Valley projects, both of which received counter guarantees from the central government.
} 


\section{- Slow pace of reforms}

- Complex bureaucracies

- $\quad$ Shifting and fragmented political system

- $\quad$ Pilferage of power estimated at 13 percent; average T\&D losses are around 18 percent

- $\quad$ Government set limit of 25 percent on ROR on equity

- Virtually all foreign-based IPPs are set up with Mauritius-based operations because under current law, they are allowed a 5 percent withholding tax on repatriated profits. The normal withholding tax is 20 perent. However, this relationship between countries could be hampered by potential changes in the tax laws in India and Mauritius.

- $\quad$ Can take up to 6 years to obtain necessary approvals:

$\triangleright \quad$ Obtaining financial assistance requires 7 agency approvals and can take 18-24 months

$\triangleright \quad$ Land acquisition requires 9 agency approvals and can take up to 4 years

$\checkmark \quad$ Water connection requires 11 agency approvals and can take 12 months

$\triangleright \quad$ Construction permits require 6 agency approvals and can take 2-3 years

$\triangleright \quad$ Electric service requires 11 agency approvals and can take up to 12 months

In India, developers have relied on central government guarantees because neither the states nor utilities have individual credit ratings. ${ }^{81}$ However, the central government became wary of providing too many guarantees, because the potential financial burden could lower the country's credit rating. It therefore stopped granting guarantees except as a last resort. To compensate, the government is developing a series of acceptable alternatives and is soliciting ideas from the private sector on new ways to encourage development.

In addition, in October 1996, Prime Minister Gowda announced recommended policy changes that would decentralize the decision-making process for private power development. If put into effect, they would grant states full authorization over proposed projects, regardless of size or cost, and would set a minimum tariff on the agricultural sector in an effort to reduce the subsidies. ${ }^{82}$

\subsection{Background for the International Private Power Developer in India}

\subsubsection{Government Approval Process}

Private project developers need the following for thermal projects:

- $\quad$ approval from the SEB

- government clearance that they have a sufficient water and fuel supply

- $\quad$ clearance from the Ministry of Environment and Forests and clearance for the stacks from the Airports Authority of India

In addition, all projects need approval from the state and central government for resettlement plans for displaced people, and they have to secure environmental and equipment procurement clearances.

\footnotetext{
${ }^{81}$ Burr, Michael, 1993, “Strategies for Success," Independent Energy, April.

${ }^{82}$ McGraw Hill, 1997, International Private Power Quarterly, First Quarter, p. 134.
} 


\subsubsection{Renewable Private Power Projects Currently in Development}

\begin{tabular}{|c|c|c|}
\hline $\begin{array}{l}\text { Location } \\
\text { Size } \\
\text { Cost } \\
\text { Fuel } \\
\end{array}$ & Developers & Notes \\
\hline $\begin{array}{l}\text { Uttar } \\
\text { Pradesh } \\
18 M W \\
\text { Bagasse }\end{array}$ & $\begin{array}{l}\text { Willard India sugar mill and a U.S. } \\
\text { company (name unavailable) }\end{array}$ & $\begin{array}{l}\text { Willard India mill signed an MOU with a U.S. company to triple the } \\
\text { capacity of its bagasse-cogeneration facility to } 18 \mathrm{MW} \text {, with the goal of } \\
\text { exporting } 8 \mathrm{MW} \text { of surplus power to the state grid. }\end{array}$ \\
\hline $\begin{array}{l}\text { Rajasthan } \\
50 M W \\
\text { Solar }\end{array}$ & $\begin{array}{l}\text { Amoco/Enron Solar Power } \\
\text { Development International Inc. }\end{array}$ & Electricity sold to Rajasthan SEB \\
\hline $\begin{array}{l}\text { Kerala } \\
25 M W \\
\$ 28 \text { million } \\
\text { Wind }\end{array}$ & $\begin{array}{l}\text { Optimum Power Corp. } \\
\text { Prudential Power Corp. of Calcutta }\end{array}$ & no information available \\
\hline $\begin{array}{l}\text { Rajasthan } \\
250 M W \\
\text { Solar }\end{array}$ & $\begin{array}{l}\text { Alenergen International Consortium } \\
\text { (incl. Energen, Sletch \& Bergmann, } \\
\text { Shartanval Investment Ltd.) }\end{array}$ & Alenergen offered the most competitive levelized tariff at $8 \mathrm{c} / \mathrm{kWh}$ \\
\hline $\begin{array}{l}\text { Gujarat } \\
2 M W \\
\text { Wind }\end{array}$ & Gujarat Synthetics Ltd. (GSL) & $\begin{array}{l}\text { Joint venture with Vestas-RRB Danish Turbines } \\
\text { GSL, a yarn maker, will use most of the power and sell excess to the grid }\end{array}$ \\
\hline $\begin{array}{l}\text { Gujarat } \\
44 M W \\
\text { Wind }\end{array}$ & Gujarat Synthetics Ltd. (GSL) & $\begin{array}{l}\text { Joint venture with Canon Power Corp. } \\
\text { GSL, a yarn maker, will use most of the power and sell excess to the grid }\end{array}$ \\
\hline $\begin{array}{l}\text { Kerala } \\
2 M W \\
\$ 10 \text { million } \\
\text { Photovoltaic }\end{array}$ & Intech Global Resources Inc. & Signed MOU with Solaris Systems Ltd. \\
\hline $\begin{array}{l}\text { Gujarat } \\
40 \mathrm{MW} \\
\text { Wind }\end{array}$ & Pearl Securities Ltd. & no information available \\
\hline $\begin{array}{l}\text { Tamil Nadu } \\
50 M W \\
\text { Wind }\end{array}$ & Newam Power Co. Ltd. (Madras) & $\begin{array}{l}\text { Output will be sold to Tamil Nadu SEB and a subsidiary of Kenetech } \\
\text { Corp. will supply equipment and build, operate, and maintain the project }\end{array}$ \\
\hline
\end{tabular}

source: McGraw Hill, 1997 \& 1996, International Private Power Quarterly. (Source for Uttar Pradesh's bagasse project is NBIA, 1995, Bagasse-Based Cogeneration in India: A Market Primer for U.S. Companies, March.) 


\subsubsection{Recent Renewable Private Power Project Solicitations and Initiatives}

As of September 1996, India had solicited 143 projects at a total of $71 \mathrm{GW}$; most of these solicitations were for small projects- 50 percent of the projects were less than $1,000 \mathrm{MW}$ each. ${ }^{83}$ The following is a list of some of the recent solicitations and initiatives in the area of renewable power in India. ${ }^{84}$

- The Ministry of Nonconventional Energy Sources (MNES) has called for private sector companies to develop wind farms, hydro units, cogeneration units and other alternative power generation stations. MNES is offering incentives such as study grants, negotiable financial support, tax holidays, and low tariffs on imported equipment.

- Tamil Nadu State Government has instituted incentives programs for wind, solar, cogeneration at sugar and paper mills, and biogas applications at appropriate locations. The SEB will pay a 12.5 percent higher tariff for private power produced by renewable resources and cogeneration units. In this vein, Foster Wheeler Corp. and India's Aruna Sugars are negotiating a 30 MW bagasse-fired cogeneration project.

- Lockheed Environmental Systems and Technologies of Texas and Econergy International Corp. of Colorado formed a partnership with the Tata Energy Research Institute to do a feasibility study and possibly develop two $50 \mathrm{MW}$ bagasse-fired cogeneration plants in Uttar Pradesh. OPIC provided a $\$ 220,000$ grant for the feasibility study.

- Belgundi Cements Pvt. Ltd. is looking for investors to expand a $5 \mathrm{MW}$ biomass plant to $30 \mathrm{MW}$. It is being built at a small cement plant and surplus power will be sold to the grid.

- The government of Andhra Pradesh approved seven private companies to develop 178.5 MW of wind farms. The entire output of the units will be purchased by the Andhra Pradesh SEB. The largest single project awarded was for a 105.75 MW site which went to New York's Intervolt Cannon Power Corp. The remaining units will be built by Indian companies.

- $\quad$ Carter Wind Turbines Inc. of Texas has signed an MOU for 4 wind projects totaling $120 \mathrm{MW}$. Contracts will be for 15-20 years and each project will be financed separately.

- Zond International Development Corp. of California and Blue Chip Technologies signed an MOU with Pentafour Solec Technology Ltd. to establish a joint venture to develop a $60 \mathrm{MW}$ wind farm in Tamil Nadu.

- The government of Andhra Pradesh is seeking private sector proposals for up to $500 \mathrm{MW}$ of power projects, each no larger than $30 \mathrm{MW}$ or costing more than $\$ 33$ million. The projects would need only state approvals and be developed under a new "transparent" policy on mini-power projects for the private sector set for release shortly.

\footnotetext{
${ }^{83}$ Poirier, Jean-Louis, 1996, "Global Power: The Big Picture," in Proceedings from the Power-Gen '96 International Conference and Exhibition, Orlando, Florida, December 4-6, p. 5. In Asia, coal and hydro account for approximately $42 \%$ and $28 \%$ of requested capacity, respectively.

${ }^{84}$ McGraw Hill, 1997 \& 1996, International Private Power Quarterly.
} 


\subsubsection{Sample List of Companies Currently Doing Business in India}

Applied Industrial Materials Corp.

Asea Brown Boveri

Canasia Power Corp.

Enron Development Corp.

Essar Power Ltd.

GEC-Alsthom

General Electric Co.

Houston Industries Energy Inc.
International Generating Co.

PowerGen International

Rolls-Royce Power Ventures

Siemens Power Ventures

Smith Cogeneration

Tenaga Nasional Board

Torrent

Westinghouse

\subsection{Summary}

The nature of India's climate for biopower development is not as obvious as it appears on the surface. It has a rapidly increasing electricity demand and as a predominantly agrarian economy, it has the potential to produce large amounts of biomass resources. However, an entrenched agricultural subsidy structure and competing uses for land and resources make biopower a more viable option for niche markets than for widespread applications. The country's sugar industry appears to be the best option for developers in the near term, because of the steady supply of excess bagasse and the ability of sugar mills to sell surplus power to the grid. Other near-term areas of interest are waste to energy projects and some repowering and co-firing options. Various biopower opportunities are discussed in greater detail in chapter 9.

As for investment climate, renewable energy in India does not suffer from a lack of institutional support. The government has actively promoted all types of renewable energy as a way to mitigate the environmental effects of extensive coal use, and international developers can take advantage of financial incentives specifically targeting renewable power. However, the SEBs and the central government have to convince developers that they are removing the inefficiencies and logjams that can decrease both state and central government credit ratings and overall attractiveness to investors. India's ability to improve its standing in the international power market will hinge on such efforts because developers will ultimately go to the market which has the best combination of risk and return. 


\subsection{CHINA-ENVIRONMENT FOR BIOMASS PRIVATE POWER DEVELOPMENT}

China's huge economic growth is forcing the country to rapidly expand its electric generation capacity. As in India, coal is, and will continue to be the predominant fuel used to generate power. However, the extensive pollution associated with the burning of coal has led to severe health and environmental problems. The amount of suspended particulate in the air in China is ten times higher than what is deemed acceptable by the World Health Organization. ${ }^{85}$ As a result, China is interested in more environmentally benign power options, such as hydroelectricity, clean coal technology, and natural gas-fired generation.

Non-hydro renewables including biomass are of interest, but they have not benefitted from formal central government and institutional support. A recent study by the World Bank concludes that the U.S., the United Kingdom, and India are the best markets for renewable power because they provide central government support, policy initiatives, and financial incentives for its development. ${ }^{86}$ China, however, has not given similar priority to renewable power development; for example, the government established a New \&

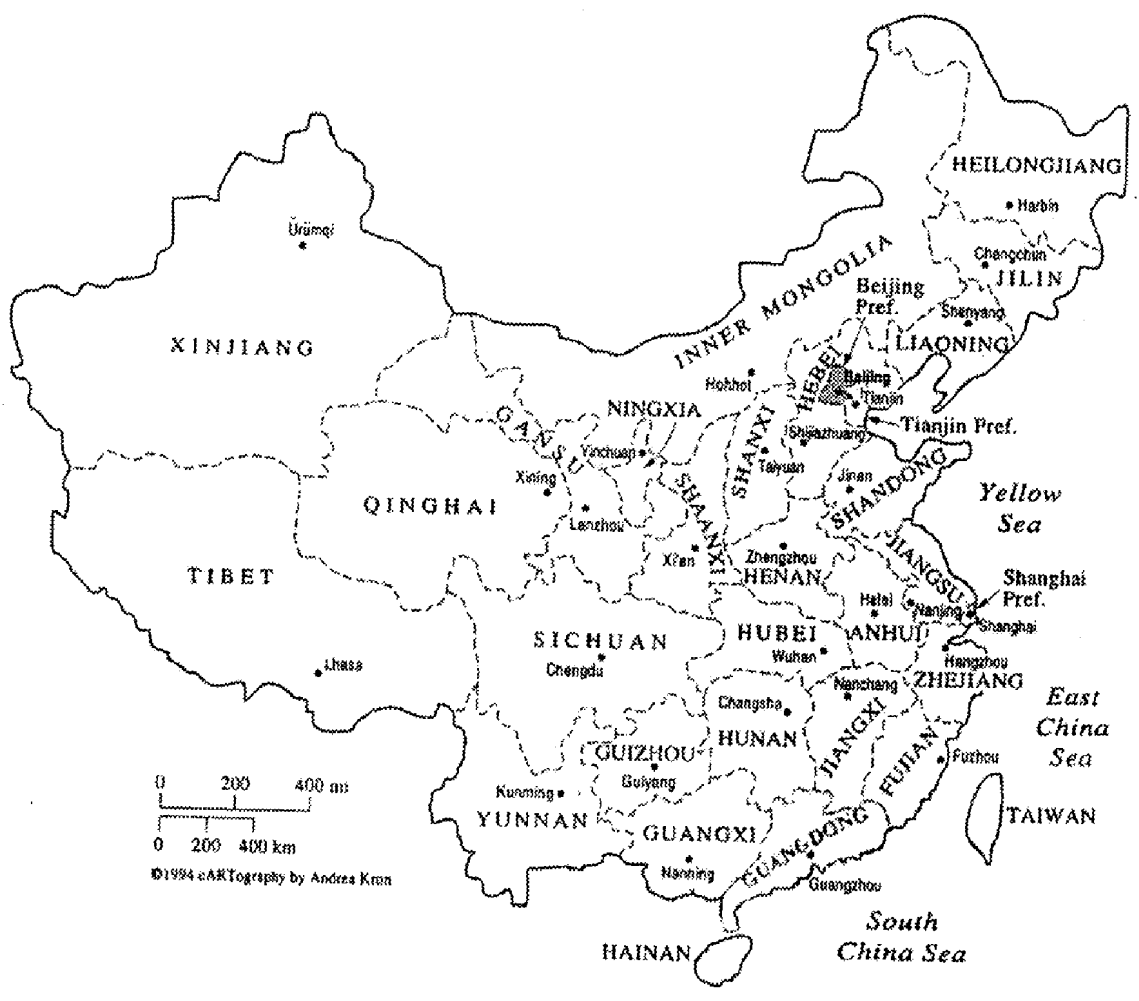
Renewable Energy Development Program, but has not allocated any specific budget amounts to it. ${ }^{87}$ The lack of capital in a transitioning economy shifts the money to more pressing needs. Experience has shown that renewable power development cannot flourish on its own. China has to devote resources to policy development and technical assistance before renewable power projects can be sustained in the long term.

Although China is the biggest market for power generation in general, without proper institutional support, this is not necessarily the case for biopower. However, pilot projects in the sugar and pulp and paper industries are viable short-term opportunities. Biomass distributed systems may also be applicable, depending on the government's priority for providing reliable power to rural areas. As in India, a growing urban waste problem elevates waste-to-energy as a potential biopower opportunity for a developer.

\footnotetext{
85 "In Search of Satisfaction," 1997, The Economist-A Survey of China, March 8.

${ }^{86}$ The World Bank, 1996, China: Renewable Energy for Electric Power, September 11.

${ }^{87}$ Ibid.
} 
However, not only does biopower suffer from a lack of support in China, but it has to compete with coal and hydro, the technologies of choice. The hope is that the sheer amount of power needed to meet future demand, a large agrarian economy, growing environmental concerns, industrial inefficiencies, the urban MSW problem, and the need for rural electrification can provide more niche opportunities for the persistent and patient biopower developer.

This chapter outlines the environment surrounding biomass power development in China by focusing on the electric power industry, electricity tariffs, indigenous fuels that compete with biomass, the economic and political climate, energy/environmental policy, and the investment climate. To provide the international developer with a snapshot of the actual climate in China, the remainder of this chapter outlines the government approval requirements, lists the renewable energy projects currently in development, describes recent power project solicitations, and provides a list of companies currently engaged in projects in China.

\subsection{Electric Power Industry}

China's electric power industry is organized under the Ministry of Electric Power (MEP), which was formed by the State Council in 1992. Production and transmission are controlled by sixteen power networks at either the provincial or inter-provincial level, all under the direction of the MEP. The MEP is responsible for planning, international cooperation, safety and production coordination, and capital construction coordination. The State Planning Commission overseas the decisions of the MEP concerning large power projects.

Provincial power companies control the state power plants but are financed by the central government. These power companies formerly had monopoly control over electricity production, but their role is being reduced; in some coastal provinces, they now provide less than half of the total electricity generated. The remainder is produced by joint-investment power plants and independent power producers. Transmission is still controlled by the provincial power companies and distribution is undertaken by county-level power companies.

\subsection{Electricity Tariffs}

China's electricity consumption more closely mirrors a trend typical of an industrializing country. Industry is the largest consumer at 75 percent of the total, followed by residential and commercial at 14 percent combined, with the agricultural sector a distant fourth. ${ }^{88}$ Industrial and agricultural sectors' shares of the total declined since the early 1980 s, mainly due to the residential sector's increased consumption of appliances and new commercial construction.

A large portion of electricity tariffs is allocated by quotas. The "in-plan" quota is a state fixed price that is applied to electricity generated from central government-owned plants, which includes almost all plants constructed before 1985. Power produced from new plants (post-1985) is allocated to consumers in an "out-of-plan" quota, which is a guidance price. This price is set to cover the repayment of loan principal and interest. Most power generation capacity in China falls under either of these two quota systems.

${ }^{88}$ Sinton, Jonathan E., ed., 1993, China Energy Databook, 1992 Edition, June, p. IV-5. 
The third "quota" group represents generating capacity that has not been financed by the central government. These plants can sell production at a negotiated price higher than the state price, although the margin is still controlled by the government. This group includes the independent power plants, provincial/local government-financed power plants, and power supplies above the plan quotas.

On average, China's electricity tariffs are close to the cost of production. Rates range from $2.0-4.0 \mathrm{~d} / \mathrm{kWh}$, with the residential sector paying the highest price. ${ }^{89}$ Rates between 5-7 c/kWh are needed to support a new coal-fired power plant. ${ }^{90}$ This gap in tariff rates is a point of concern for private developers. The government has decided to revamp the tariff system by phasing in a new set of tariffs over several years. It will charge higher rates during peak demand periods, and the industrial and commercial sectors of Shanghai will be among the first pilot projects to use peak and off-peak tariffs.

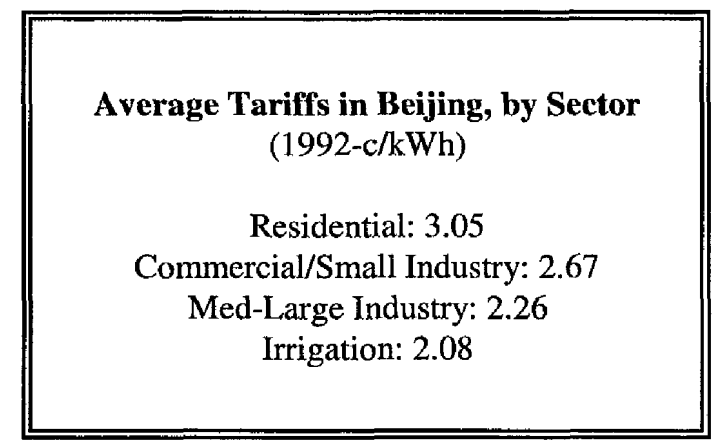

\subsection{Competing Fuels}

As in India, biomass in China will have to compete with the country's abundant fossil fuel reserves and their dominance in the fuel generation mix. Seventy-percent of the country's installed generation capacity is from coal, 10 percent is from oil, gas, and nuclear, and 20 percent is from hydro. The country has also invited foreign companies to further explore its oil and gas reserves. Because of such strong competition, this section first lists the fossil reserves in China and then concludes with a description of its coal industry.

\subsubsection{Reserves ${ }^{91}$}

$\begin{array}{lr}\text { Coal: } & 114.5 \text { billion tonnes } \\ \text { Oil: } & 3.2 \text { billion tonnes }\end{array}$

Natural gas: 1,400 billion cubic meters $(\mathrm{bcm})$

Oil and natural gas are not as promising as coal because the country has already become a net oil importer. The country has virtually no gas pipeline system to transport natural gas fuel. However, the government is encouraging foreign companies to explore and develop new oil and gas fields, with the goal of diversifying its energy resource options.

\footnotetext{
${ }^{89}$ DRI/McGraw Hill, 1996, The Future of the Electric Power Industry, p. 69.

${ }^{90}$ McGraw Hill, 1997, International Private Power Quarterly, First Quarter, p.62.

${ }^{91}$ McGraw Hill, 1996, The Future of the Electric Power Industry.
} 
Regional Distribution of Energy Sources in China (\%)

\begin{tabular}{|l|c|c|c|c|}
\hline Region & Coal & Hydropower & Oil/gas & Total \\
\hline \hline Northeast & 3.1 & 1.8 & 48.3 & 3.8 \\
\hline North & 64.0 & 1.8 & 14.4 & 43.9 \\
\hline East & 6.5 & 4.4 & 18.2 & 6.0 \\
\hline Central South & 3.7 & 9.5 & 2.5 & 5.6 \\
\hline Southwest & 10.7 & 70.0 & 2.5 & 28.6 \\
\hline Northwest & 12.0 & 12.5 & 14.0 & 12.1 \\
\hline
\end{tabular}

source: Wu and Li, 1995, p.169 (Ministry of Energy).

Since coal and hydro comprise a large share of the total fuel reserves, they have shaped most of China's electricity generation mix. However, as shown in the table above, the problem with China's energy distribution is that the resources are not located close to population centers (the East, Northeast, and Central South regions). As a result, either the fuel or the power has to be transmitted from remote regions to the load centers. Section 5.3.2 discusses some recent alternatives to the issue of unequal distribution.

\subsubsection{Coal}

The amount of coal in China is equivalent to 11 percent of the world's proven reserves. Most of the coal in China is mined in the northern and northeastern provinces from state-owned mines and small, collectively and individually owned mines. ${ }^{92}$ Capital investment for state coal mines traditionally comes from the central government which sets the coal prices far below market prices. As in India, coal demand exceeds production and it accounts for the largest percentage of freight transported by an aging rail system. Because of its abundance and historical presence, coal will continue to be the fuel of choice for power generation, estimated to represent 72 percent of total capacity by $2020 .{ }^{93}$

The government has recognized the shortfalls of the current coal supply and delivery industries so it has taken steps to diversify its consumption patterns. The geographic gap between coal supply and demand for power recently led China to import 200,000 tons of Australian coal, at a cost of $\$ 10$ million, to fuel a power plant in Guangdong Province. ${ }^{94}$ The Chinese government found that importing coal was cheaper than transporting it from northern China along congested rail lines. Another example is Pittsburgh's Custom Coals International Corp.'s recent signing of a joint-venture agreement with a subsidiary of the Chinese Ministry of Coal to build an $\$ 889$ million, 500-mile, 15-million ton/year capacity underground coal slurry pipeline, coal cleaning plant, and port facility. It will be built in northern China on a BOT basis with a fifty-year term. It is scheduled for completion in late 1997 and will run from the northern province of Shanxi (which holds 27 percent of the nation's coal reserves) to Shandong, thus avoiding rail transport of coal.

\footnotetext{
${ }^{92}$ Sinton, Jonathan E., 1993, China Energy Databook, p. II-2.

${ }^{93}$ DRU/McGraw Hill, 1996, The Future of the Electric Power Industry.

${ }^{94}$ DRI/McGraw Hill, 1997, International Private Power Quarterly, First Quarter.
} 


\subsection{Economic Climate}

In the next several years, China will probably become one of the world's largest economies. According to World Bank figures, on a purchasing power parity basis ${ }^{95}$ China had the world's second largest economy in 1994 , with a per capita gross national product of $\$ 2,510$ and a population of about 1.2 billion people. ${ }^{96}$ Its gross domestic product (GDP) grew an average of 10 percent annually over the last decade, largely due to investment and export growth, and it is expected to stabilize to 6-8 percent per year in the next decade. ${ }^{97}$ However, price increases and a revival of domestic demand has boosted inflation from 12 percent between 1991 and 1994 to 15 percent in $1995 .{ }^{98}$

China's enormous projected demand for electricity stems from its rapid economic growth and increased rural electrification. Electricity shortfalls have occurred in the past because the country's industrialization programs did not adequately invest in the electric power industry. Further, more than 70 percent of China's population is rural, and although 90 percent of the rural areas have access to electricity, 120 million people are still without any electric power. To meet these goals, the government plans to reach an installed capacity of $1,100 \mathrm{GW}$ by the year $2020 .{ }^{99}$

The economy, however, has been adversely affected by unfocused internal growth patterns. All great modern economic powers have been predominantly urban entities. Ironically, for all its economic success, China's urbanization rate has been slow and not well planned; only 29 percent of the population lives in cities. City growth has been controlled and industry is arbitrarily scattered throughout urban and rural areas, far from major markets. ${ }^{100}$ This lack of a concentrated, megalopolis-style development has prevented China from benefitting from economies of scale.

"With no farming, there's no security. With no industry, no wealth.

With no commerce, there's no flexibility. And with no foreign joint ventures, there's no short-cut."

Common saying in rural parts of Jiangsu Province

Source: The Economist-A Survey of China

Rural industrialization has also been characterized by haphazard growth patterns. Vegetable plots and factories share the same land, zoning is random, often wasting precious farmland, and pollution is overwhelming. ${ }^{101}$ Thus, as indiscriminate rural industrialization diminishes farmland, biomass that can be used for power generation will be further constrained. Further, as in India, biomass resources are limited

\footnotetext{
95

95 The World Bank defines "purchasing power parity" as the number of units of a country's currency that is required to buy the same amounts of goods and services in the domestic market as one dollar would buy in the U.S.

${ }^{96}$ GAO Testimony, 1996, International Trade: Challenges and Opportunities for U.S. Businesses in China, p. 1.

${ }^{97}$ DRI/McGraw Hill, 1996, The Future of the Electric Power Industry, p. 71.

${ }^{98}$ The Economist Intelligence Unit, 1997.

${ }^{99}$ McGraw Hill, 1996, International Private Power Quarterly, Fourth Quarter.

100"City Life," 1997, The Economist-A Survey of China, March 8

${ }^{101}$ Ibid.
} 
from the start because often they are already "commodities." Ultimately, as the nation continues to grow, it cannot afford to ignore the pitfalls of its random development patterns, in either the urban or rural areas.

Foreign investment has targeted select areas and exacerbated this inter-regional variation. Of the total foreign funds that China absorbed in 1995, approximately 88 percent flowed to its three centrally administered municipalities and its nine coastal provinces. ${ }^{102}$ Unless the government offers more incentives to spread investment throughout the country, private developers will try to minimize risk by continuing to go to these "established" markets. Hence, the nation will suffer from more unequal development which has already created much regional rivalry; some state that this conflict is the biggest internal problem facing the country.

General Economic Indicators $^{103}$

GDP (1995):

GDP breakdown:

Real GDP growth rate (1995):

Inflation rate (1995):

Unemployment rate (1994):

Foreign reserves (1997):

Official Development Assistance receipts (1993):

ODA disbursements as \% of GNP (1993):

Percentage of total current revenue (1993) -
695 billion in U.S.\$

Agriculture (21\%); Industry (45\%); Services

(27\%)

$10.2 \%$

$15 \%$

$2.7 \%$

$\$ 104.3$ billion

3,273 million U.S.\$

$0.8 \%$

Tax revenue from income, profit, capital gains: $36.9 \%$

Tax revenue from social security:

Tax revenue from goods \& services:

0

$15.3 \%$

Tax revenue from international trade

$\&$ transactions:

$16.9 \%$

Other tax revenue:

0

Non-tax revenue:

$30.9 \%$

\section{Major Industries}

$\begin{array}{llll}\text { armaments } & \text { coal } & \text { iron and steel } & \text { textiles and apparel } \\ \text { autos } & \text { consumer durables } & \text { machine building } & \\ \text { cement } & \text { consumer electronics } & \text { petroleum } & \\ \text { chemical fertilizers } & \text { food processing } & \text { telecommunications } & \end{array}$

Trade

Major Trading Partners: Major Export Products: Major Import Products:
Hong Kong, Japan, U.S., Taiwan, Germany, Russia

Textiles, garments, footwear, toys, crude oil

Rolled steel, motor vehicles, textile machinery, oil products

\footnotetext{
102,"China: Uncertain Future for FDI," 1997, The Economist Intelligence Unit.

${ }^{103}$ World Bank, 1995, World Data 1995 CD-ROM and The Economist Intelligence Unit, 1997.
} 


\subsection{Political Climate}

Since the People's Republic was established in 1949, there have been different attempts at reform. Deng Xiaoping's economic reforms, introduced with his rise to power in 1978, were the most influential on the Chinese economy. These included:

- liberalizing agricultural and industrial production

- freeing prices

- promoting regional economic specialization

- $\quad$ opening the economy to foreign trade and investment

Due to this reform program, the provinces and localities began to have considerably more economic autonomy, with the prime beneficiaries being the coastal provinces.

Unless President Jiang Zemin keeps the country moving on its growth trajectory, the conflict between traditional philosophy and economic necessities may be exacerbated in the aftermath of Deng's death. During his recent trip to China, Vice President Gore said that Zemin and Premier Li Peng "made it clear in their comments that they intend to take further steps to open the Chinese market more to U.S. goods and services." 104 While this is promising news for U.S.-Chinese relations, China is facing many hurdles: new leadership, survival of the most favored nation trade status, human rights issues, intellectual property rights protection, pollution concerns, its relationship with Taiwan, and the transference of Hong Kong to Chinese rule. These can delay foreign business involvement in the near- to medium-term.

\subsection{Environmental and Energy Policy}

This section discusses China's environmental and energy policies. As in India, they are comprehensive and far-reaching, but lax enforcement of these regulations is the paramount issue. The Chinese government has set goals for renewable energy, but biopower only represents a small portion.

\subsubsection{Environmental Policy}

Traditional Chinese policies regarding the environment were independently formulated by departments that ignored the relationships between economic, social, and environmental factors. After the United Nations Conference on Environment and Development in June 1993, the Chinese government put forth more comprehensive environment and development proposals which were supplemented with suggestions for more linkages between disciplines, efficient regulations, and greater use of economic and accounting systems. ${ }^{105}$

As stated, however, inconsistent enforcement is more of a problem than lax regulation. Although the more sophisticated cities such as Beijing and Shanghai enforce regulations more carefully than smaller cities,

\footnotetext{
104

${ }^{04}$ Harris, John F., 1997, “Gore Fumbles in Juggling 2 Messages," The Washington Post, March 27, p. A1.

${ }^{105}$ Ye, Liao, 1993, "Environmental Protection: Progress and Challenges," Beijing Review, July 12-18, p. 16.
} 
they still tend to interpret regulations inconsistently. ${ }^{106}$ International developers, therefore, may not be aware of the complete picture regarding environmental policy and permitting when trying to get a project approved, which can delay plant operation. Appendix 2 provides a description of some of China's main environmental regulations.

\subsubsection{Energy Policy}

The Chinese government set the following energy objectives for the period up to the year $2000::^{107}$

- $\quad$ maximize energy exploration and conservation efforts

- increase energy supplies through oil and gas exploration/development, hydropower, and nuclear power development

- $\quad$ replace oil with coal

- $\quad$ rationalize energy prices

- $\quad$ encourage energy conservation by strengthening energy management, promoting energy saving technology, and developing cogeneration

- $\quad$ strengthen the energy industries

- $\quad$ expedite the construction of energy distribution systems in rural areas

- $\quad$ promote technologies to raise both production and energy use efficiencies

- alleviate atmospheric pollution in urban areas caused by coal combustion and alleviate the deteriorating ecology of rural areas

While these objectives seem reasonable, the government will face many hurdles in implementing them. The structure of energy supply, demand, distribution, and pricing differs across provinces. As shown in Section 5.3.1, there is an uneven regional distribution of energy resources. As a result, in any given part of the country, the regional energy development policy takes precedence, and each of the major energy industries (e.g., coal, electricity) has its own development strategy. For example, in the Northeast, the strategy is focused on developing the oil and coal industries, while in the North, the focus is on the coal industry. An attempt was made, however, at creating a unified energy policy for the country. In 1988, the government established the Ministry of Energy to serve in this capacity. It was disbanded in 1993, giving way to independent development of each energy resource.

\section{Renewable Energy Policy}

The government's 1995 Renewable Energy Development Program outlines the following objectives: ${ }^{108}$

- To bring renewable energy development into the general plan of economic development and government budgets

- To formulate government policies favorable to renewables (including financing for $R \& D$, expanding credit, and fiscal incentives)

- To intensify scientific research and technology development programs

- To strengthen the industrial base for manufacturing and support services for renewable energy development

\footnotetext{
106"China: A Matter of Priorities," 1995, Far Eastern Economic Review, November 16, p. 71.

${ }^{107}$ Ishiguro, M. and Akiyama, T., 1995, Energy Demand in Five Major Asian Developing Countries, World Bank Discussion Paper $\# 277$, p. 29.

${ }^{108}$ The World Bank, 1996, China: Renewable Energy for Electric Power, September 11, p. 50.
} 
To bring about increased international cooperation, introducing advanced technologies and financing from abroad

Within this framework, the Chinese government estimated grid-connected windfarm potential at $250,000 \mathrm{MW}$, bagasse cogeneration at $700-900 \mathrm{MW}$, and solar PV and solar home systems at $12 \mathrm{MW}$. Other renewable energy potential such as biogas power, geothermal, and small wind generators are indicated as priorities but they need significantly more technical and financial support before they can have widespread application.

\section{Electric Power Law}

The country's first Electric Power Law regarding foreign investment in the electric power sector went into effect in April 1996. Although it supports foreign investment, it applies the following restrictions: $:^{109}$

- $\quad$ All foreign investment in the power sector has to conform with China's industrial policy and the next 5-year plan (1996-2000), and it has to be included in the government's 15-year development plan

- $\quad$ Foreign investment is only allowed in projects using coal, clean coal, natural gas, liquefied petroleum gas, hydro, and nuclear energy, with an emphasis on hydro, nuclear, and new nonpolluting technologies

- In general, no sovereign guarantees will be offered, but limited guarantees will be offered to BOT projects under special circumstances

- $\quad$ Risks and rewards are to be shared among all project participants

- Transmission and distribution projects are reserved for domestic investment

- World Bank and Asian Development Bank loans will be more widely used to finance state industry projects

The Ministry of Electric Power created the China Power Investment Corp. to raise capital internationally for power projects. It will issue corporate bonds, establish power development funds, and channel foreign investment for BOT projects. The government relaxed the unofficial 12 percent ROR cap in power purchase agreements if projects achieved certain performance standards; some developers are now experiencing a 15 percent ROR. The project availability benchmark is generally at 62.8 percent

\footnotetext{
${ }^{109}$ McGraw Hill, 1997, International Private Power Quarterly, First Quarter, pp. 61-62.
} 
availability. Once this availability is posted, the RORs can be increased following a review. Foreign developers are encouraged by this change but say that no formal Chinese policy is in place and the benchmark concept is applied selectively.

\subsection{Investment Climate}

By its eighth Five Year Plan (1991-1996), China began to emphasize power generation and broaden this market to outside investors. It attracted foreign investment in energy-intensive industries, which further spurred electricity demand. China is one of the world's fastest growing economies and opportunities seem endless, but it is commonly understood that doing business in this country poses a unique challenge. The country only attracted $\$ 26$ of foreign investment per capita because it takes "structural political-economic issues, from judicial transparency to political pluralism less seriously than other countries." 110 China's investment hurdles are also based on the intrinsic battle between its socialist structure and its need to open its markets and hence, relinquish some

\section{How China Can Successfully Attract and Implement Renewable Power}

1) provide a comprehensive regulatory and policy framework that is supported and promoted by the central government

2) provide financial incentives and other supporting institutional arrangements to accelerate market-based development of renewable power

3) develop standard power purchase agreements and tariffs and simplify the approval process

source: The World Bank control.

In general, the top concerns facing developers/investors in China have been foreign exchange and electricity prices. ${ }^{111}$ Foreign investors want central government guarantees that there will be enough foreign exchange to repatriate profits. This concern has largely been mitigated because China's foreign exchange reserves hit the $\$ 100$ billion mark in November 1996. ${ }^{112}$ Price guarantees are also important; power plants are allowed to increase tariffs, but they have to pass through several approval steps before actually being able to do so. In addition, a newly built plant requires an electricity tariff that is nearly twice the current average price for power.

To compensate for these hurdles and continue to attract foreign investment, the government has recently relaxed its rate of return (ROR) policy. For the most part, the government is interested in foreign investment, but this invitation comes with many caveats.

As stated earlier, while China is the biggest and often most popular market for overall power generation, non-hydro renewable power does not fare as well there as in other countries. As the nation's air quality deteriorates, the citizens and the government are still experimenting with alternative ways to intigate pollution and meet a rising electricity demand. Government plans, however, do not consider biopower as one of the top solutions. The following list ${ }^{113}$ of pros and cons provides an overview of the business and

\footnotetext{
110 "The Importance of Foreign Devil Money," 1997, The Economist--A Survey of China, March 8. For comparison, Malaysia attracted $\$ 226$ per capita and Mexico, Chile, Poland, and Hungary each attracted more money than China.

${ }^{111}$ DRI/McGraw Hill, 1996, The Future of the Electric Power Industry, p.78.

112,"China: New Deals Put Power Stations Back on Line," 1997, The Economist Intelligence Unit.

${ }^{113}$ Unless otherwise stated, this information is from: McGraw Hill, 1997 \& 1996, International Private Power Quarterly.
} 
investment climate for foreign company power development in China. The items underlined specifically relate to renewable power.

\subsubsection{Pros}

- The government included bagasse-fired cogeneration at sugar mills as an element of its renewable power policy.

- The Ministry of Electric Power is soliciting \$25 billion of foreign capital for $300 \mathrm{GW}$ of new electric generation capacity.

- Approximately $68.5 \mathrm{GW}$ of new capacity needed by 2000 will be developed by the private sector. There are also outstanding proposals for about $57 \mathrm{GW}$ of private power.

- Recent power projects are getting a ROR of around 15\% which is comparable to rates received in other markets with similar risk levels.

- Has double tax treaty with the U.S., so developers only have to pay taxes in one country.

- $\quad$ Enacted Guarantee Law in 1995 which gives parties to project financing a better legal framework in which to seek, perfect, and enforce security interests throughout China.

- Direct investment and exports have fostered a current account surplus and strong foreign reserves

- Foreign joint ventures pay only $15 \%$ corporate tax in special economic zones. ${ }^{114}$

- In July 1996, China moved towards full currency convertibility by allowing foreign companies to buy and sell Chinese currency, the yuan, without government permission. This policy applies to current account transactions and allows currency to be converted for the purposes of trade, debt payment, and repatriation of profits. Capital account convertibility, however, must still be approved by the government.

- $\quad$ Since the beginning of 1994 , the yuan to U.S. dollar exchange rate has stabilized.

- $\quad$ China has promised to remove nearly $90 \%$ of its non-tariff import restrictions over the next 5 years.

- The country is moving towards using international ISO standards and is interested in joint arrangements with standard-setting organizations.

- $\quad$ Overall country credit rating: GOOD ${ }^{115}$

\subsubsection{Cons}

- $\quad$ Renewable power does not have tangible central government support.

- $\quad$ Private power approval process requires a minimum of 12 months, but usually takes 24 months.

- Power project development is disorganized and redundant: provinces operate independently and within larger provinces; large metropolitan areas initiate project development where needed; and overlaid on these decisions are the orders from the Chinese Central Planning Council, which makes independent project development decisions.

- Large projects (over $25 \mathrm{MW}$ ) have to get approval from several sources: the Ministry of Electric Power, the local planning commission, the State Planning Commission, and the Ministry of Foreign Trade and Economic Cooperation. Medium- to small-sized power projects in coastal provinces generally require fewer levels of approval.

- All electricity revenues are received in yuan and capital account convertibility still needs government approval.

\footnotetext{
${ }^{114}$ However, China is in the midst of overhauling such tax policies, to remove preferential treatment for foreign investors.

${ }^{115}$ Rating derived from a U.S. credit agency's risk assessment, based on analysis of economic, political, and social indicators that assess such issues as: ability of country to generate sufficient foreign exchange; willingness to create favorable climate for trade and foreign investment; and resilience of economy to withstand domestic and external shocks. Range of credit ratings: excellent, very good, good, low, very low.
} 
- $\quad$ The Chinese government has to approve the monetary conversion and there is no assurance that it will allow companies to convert enough yuan into foreign currency to meet their financial obligations.

- The Chinese component of an international joint venture is solely responsible for plant operations.

- Foreign ownership is limited to $49 \%$.

- China denies U.S. and other foreign companies national treatment. ${ }^{116}$

- An April 1996 law establishes broad principles regarding the setting of power tariffs. However, it is unclear how this law will affect future foreign power developers or the current power tariff structures they have already set up.

- Relatively new legal system, so foreign investors may be adversely affected by new laws, changes to existing laws, and the subjugation of national law to provincial or local law.

- China has only one private bank and no meaningful capital markets, so financing rests almost solely with state banks, which have bad loans equivalent to more than 30 percent of GDP. ${ }^{117}$

- Regulatory and legal enforcement is limited.

- Government is limited in its ability to control inflation.

- Government will not issue guarantees on tariff convertibility.

- Local bond and equity markets are still in very early stages of development.

- Policy implemented in April 1996 imposes duties on the importation of capital equipment. ${ }^{118}$

\subsection{Background for the International Private Power Developer in China}

\subsubsection{Government Approval Process}

All electric power projects and foreign investments are required to obtain approvals from one or more local, provincial, or central government authorities:

- $\quad$ Projects with investment $>=\$ 100$ million -- need approval from the State Council

- Projects with investment $<\$ 100$ million -- State Council delegated approval authority for these projects to ministries, including the State Planning Commission

- $\quad$ Projects with investment $<\$ 30$ million -- State Planning Commission delegated approval authority for these projects to provincial governments, provincial level burcaus of the Central Government, and certain municipalities

In addition to these project approvals, foreign investment must be approved by the Ministry of Foreign Trade and Economic Cooperation or one of its provincial/local departments, and by the appropriate government level planning authorities.

\footnotetext{
${ }^{116}$ GAO Testimony, 1996, International Trade: Challenges and Opportunities for U.S. Businesses in China, July 29, p. 4. This is the act of treating a foreign product or supplier no less favorably than domestic suppliers.

117 "The Death of Gradualism,” 1997, The Economist-A Survey of China, March 8. By comparison, bad loans from the U.S.'s savingsand-loan crisis were equivalent to about 2 percent of GDP.

${ }^{118}$ Exemptions to this policy may be forthcoming.
} 


\subsubsection{Renewable Private Power Projects Currently in Development}

\begin{tabular}{|c|c|c|}
\hline $\begin{array}{l}\text { Location } \\
\text { Size } \\
\text { Cost } \\
\text { Fuel } \\
\end{array}$ & Developers & Notes \\
\hline $\begin{array}{l}\text { Inner } \\
\text { Mongolia } \\
110 \mathrm{MW} \\
\$ 85 \text { million } \\
\text { Wind }\end{array}$ & $\begin{array}{l}\text { FloWind Capital Corp. } \\
\text { Inner Mongolia Electric Power Corp. }\end{array}$ & no information available \\
\hline $\begin{array}{l}150 \mathrm{MW} \\
\text { Solar }\end{array}$ & $\begin{array}{l}\text { Enron Solar } \\
\text { Amoco Corp. }\end{array}$ & $\begin{array}{l}\text { Conducting a feasibility study after signing a pact with } \\
\text { China's State Science and Technology Commission }\end{array}$ \\
\hline $\begin{array}{l}75 \mathrm{MW} \\
\text { Wind }\end{array}$ & New World Power Corp. of Connecticut & $\begin{array}{l}\text { Signed letter of intent to form a joint venture with } 2 \text { Chinese } \\
\text { companies to develop } 2 \text { wind farms, } 50 \mathrm{MW} \text { and } 25 \mathrm{MW} \text {, on } \\
\text { Nanao Island, Guangdong Province and in Shenzen City. } \\
\text { New World will be responsible for debt financing, technical } \\
\text { expertise, selection of equipment/material, and will assist } \\
\text { with technology transfer and in-country manufacturing and } \\
\text { assembly. } \\
\text { The local partners will secure the use of selected land, assist } \\
\text { in obtaining proper approvals and registration, and provide } \\
\text { grid connections. }\end{array}$ \\
\hline $\begin{array}{l}25 M W \\
\text { Waste-to- } \\
\text { energy }\end{array}$ & Waste Management International of London & $\begin{array}{l}\text { Signed a MOU with Guangzhou Province to conduct a } \\
\text { feasibility study on using MSW to generate electricity and } \\
\text { deal with municipal waste problem in Canton area }\end{array}$ \\
\hline
\end{tabular}

source: McGraw Hill, 1997 \& 1996, International Private Power Quarterly.

\subsubsection{Recent Renewable Private Power Project Solicitations and Initiatives}

As of September 1996, China solicited 119 projects at a total of $167 \mathrm{GW}$, where 77 percent of the solicited capacity is for projects at a minimum size of $1,000 \mathrm{MW} .{ }^{119}$ The following is a list of some of the recent solicitations and initiatives in the area of renewable power in China. ${ }^{120}$

- Guangdong and Guangzhou Provinces released solicitations for developers to build, own, and operate two waste-to-energy projects. One will be a 1,000 tons-per-day solid waste incinerator and the other will be a 600 tons-per-day solid waste incinerator. In both cases, the electricity will be sold to the local electric power bureau or industrial customers.

- Yunnan Provincial Hydroelectric Power Dept. issued a solicitation for 8 hydro projects totaling $700 \mathrm{MW}$, most to be developed on a BOT basis. Developers are guaranteed a 15.5 percent ROR and equity levels can range from 25 to 80 percent, depending on negotiation and investment levels.

\footnotetext{
${ }^{119}$ Poirier, Jean-Louis, 1996, "Global Power: The Big Picture," in Proceedings from the Power-Gen '96 International Conference and Exhibition, Florida, December 4-6, p. 5. In Asia, coal and hydro account for approximately $42 \%$ and $28 \%$ of requested capacity, respectively.

${ }^{120}$ McGraw Hill, 1997 \& 1996, International Private Power Quarterly.
} 
- Sichuan Water Conservancy \& Hydroelectric Power Department issued a solicitation for two hydro projects totaling $142 \mathrm{MW}$ that will be developed on a BOT basis. A 15.5 percent ROR is guaranteed and equity levels can range from 25 to 80 percent, depending on negotiation and investment levels.

- Sichuan Province is seeking private investments in 15 projects totaling 1,114 MW. The projects are a mix of hydro (214 MW) and thermal $(900 \mathrm{MW})$, and are offered as either joint venture projects with Sichuan Province, which will buy the output, or as 100 percent foreign-owned plants. Estimated total development costs are $\$ 1.55$ billion. Return on investment is expected to range from 12.2 to 21 percent, with an investment recovery period of 3 to 9 years.

- Sichuan Province is seeking international partners for the financing and construction of the country's second largest hydroelectric plant, the 3,300 MW Pubugou project. Equipment and services will be sourced internationally, if offers are competitive.

\subsubsection{Sample List of Companies Currently Doing Business in China}

\author{
AES China Generating Co. Ltd. \\ AIG Asian Infrastructure Fund \\ Consolidated Electric Power Asia Ltd. \\ Enron Development Corp. \\ Exxon Energy \\ GE Capital Corp.
}

\author{
Illinova Generating \\ Siemens AG \\ Singapore Power International \\ Sithe Energies Inc. \\ United Development Inc. \\ Westinghouse
}

\subsection{Summary}

Despite China's large agrarian economy and incomplete rural electrification efforts, the overall climate for biopower in China is not favorable compared to conventional fuels and to some renewables such as wind. To combat air pollution concerns, the government is focusing on alternatives such as clean coal technology and hydroelectricity instead of non-hydro renewables. Biopower in China, therefore, will also be best suited for niche applications. Bagasse-fired cogeneration at sugar mills, rural electrification, waste-toenergy, and potential repowering and co-firing options are the most viable in the near term. Various biopower opportunities will be further discussed in chapter 9 .

The country's investment climate for power is showing improvement. The allowable rate of return has been raised, foreign exchange is abundant, and as of now, the new leadership seems to be interested in maintaining the economic growth trajectory that Deng Xiaoping plotted. However, the nation's longstanding socialist structure and slow pace of economic liberalization prevent the investment climate from changing overnight. As many developers have already discovered, doing business in China involves patience and a willingness to establish relationships that are the foundations of a successful business experience in the country. Unless the country addresses contentious issues such as human rights and the future of Hong Kong and consistently proves that it wants international investment in renewable energy (by providing a transparent business environment), these developers will eventually move to other, less risky, more supportive markets. 


\subsection{OTHER TARGET COUNTRIES}

Although sheer numbers make India and China the biggest potential markets for the next twenty years, there are three other countries that are also strong candidates for biomass power: Brazil, Indonesia, and the Philippines. These countries meet the following criteria: a substantial future demand for power, a significant agrarian economy, and a willingness to invite foreign investment. By 2020 , Brazil is projected to add $125 \mathrm{GW}$ of electric generating capacity and Indonesia is expected to add another $104 \mathrm{GW}$ of capacity; by 2025 , the Philippines is expected to add $92 \mathrm{GW}$ of capacity. ${ }^{121}$ They also have adequate resources to support biomass power.

\subsection{BRAZIL-Environment for Biomass Power}

Brazil is a top candidate for biomass power due to its resources and experience with biomass energy. Its generating capacity in 1994 was $45 \mathrm{GW}$, and it is expected to add another $125 \mathrm{GW}$ of capacity by the year 2020. The power generation mix for Brazil is currently dominated by hydroelectric power. Approximately 96 percent of the country's power is generated using this resource. The majority of the remaining 4 percent is fossil-fired capacity. As shown in section 6.1.1, Brazil has significant potential for biomass resources. More importantly, the country has historically made use of biofuels/biomass resources and has taken a proactive stance towards biomass energy. On the investment side, private power developers have been given greater flexibility, but high inflation and tax burdens compound the risk associated with foreign investment in Brazil. These issues are discussed below.

\subsubsection{Biomass Resources}

Brazil has an abundance of biomass technical potential. This is primarily due to its energy crop and industrial roundwood resource potential. As explained in Chapter 2, the agricultural residues, industrial roundwood residues, and sugar mill technical potential numbers represent the maximum available resource, if all the residues were used for power generation. The energy crop figure represents the technical potential if three percent of all agricultural land were set aside for growing these crops.

$\begin{array}{lr}\text { Agricultural production residues: } & 8.3 \mathrm{GW} \\ \text { Industrial roundwood residues: } & 11 \mathrm{GW} \\ \text { Energy crops: } & 23 \mathrm{GW} \\ \text { Power from sugar mills: } & 2.0 \mathrm{GW}\end{array}$

\subsubsection{Examples of Biomass Power Efforts}

Brazil has historically made use of biofuels/biomass resources and has taken a proactive stance with bioenergy. For example, its substitution of ethanol for gasoline in cars and light vehicles is one of the largest commercial biomass-to-energy programs in the world. Through this nationwide program, the public became exposed to biomass fuel and accepted it as a more conventional energy source, and researchers were able to improve the efficiency of using agricultural residues, a dominant resource for biomass-fueled electricity. Furthermore, Brazil's reforestation policy of the 1960 s spurred the establishment of eucalyptus and pinus plantations in the southern and southeastern regions of the country. As a result, the country has a few decades of experience with energy crops. The government is also interested in furthering its bioenergy capabilities. It is offering financing to facilitate development of

${ }^{121}$ McGraw Hill, 1996, International Private Power Quarterly, Fourth Quarter. 
cogeneration projects, and it has stated that there may be potential for up to $6 \mathrm{GW}$ of bagasse-fired cogeneration capacity in Sao Paulo, which is three times the technical potential figure estimated above.

\subsubsection{Economic and Investment Climate $^{122}$}

Although an agreement was reached with creditor banks to reduce its foreign debt, Brazil's economy suffers from high inflation and a corruption-shaken government. In 1995, its GDP growth rate was 4.5 percent, but inflation was 23.2 percent. To circumvent the effects of rampant inflation, in 1993, Brazilian officials introduced the "Cruzero Real" to replace the cruzado currency, because inflation created figures too large for even simple transactions to be done on calculators. The Real is pegged to the U.S. dollar and is fully convertible. This currency replacement was complemented by the election of President Cardoso and his anti-inflationary plans, which is believed to be the turning point for foreign investment in Brazil.

Brazil's national development bank states that there could be an electricity shortage of 11 percent by 1999 , most of which is due to insufficient investment in the electric sector. It estimates that to the year 2000, an annual investment of approximately $\$ 3.3$ billion is needed. This poses a huge problem since most investors are reluctant to commit to an electricity sector that has no clear institutional or regulatory structure in place.

The Brazilian government recognized this deterrent and has taken an active stance regarding privatization of its electric power sector. In addition to recent controls on inflation, Brazil offers the following incentives for private power development: $22.5 \mathrm{GW}$ of new capacity will be bid to the private sector by 2000; foreign and domestic capital are treated equally; a 1995 law liberalized the investment climate for independent power producers; and the Cardoso administration appears committed to pushing a National Privatization Plan for the electricity sector.

In June 1996, the state-owned utility Electrobras and the Ministry of Energy and Mines awarded a contract to a consortium headed by Coopers \&

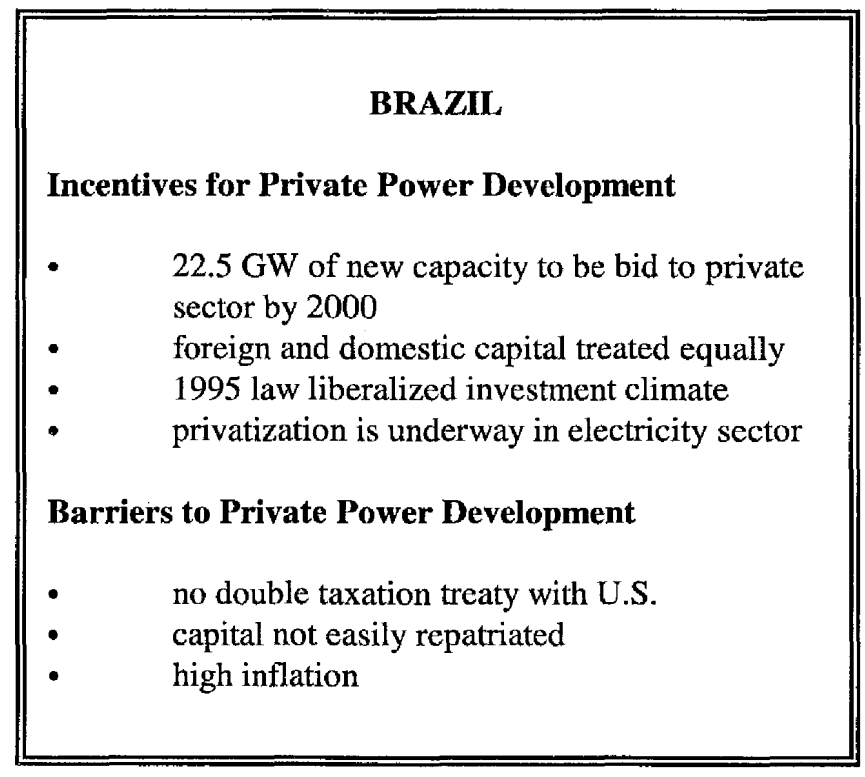
Lybrand that included some Brazilian firms.

The contract is aimed at designing a regulatory model and industry structure that will attract foreign investment in the country's electric sector. During the same month, legislation was passed that allows Sao Paulo State, which holds around 22 percent of the country's population, to restructure its electric utility sector in order to facilitate privatization. Most of the hydro potential has been tapped, so the state needs new strategies for meeting future demand growth. By the end of this year, Electrobras announced that it will sell the rights to build and operate eleven hydroelectric projects totaling $2.3 \mathrm{GW}$.

Nevertheless, there are numerous barriers associated with investment in Brazil: it does not have a double taxation treaty with the U.S., so companies are subject to taxes in both countries; the top tariff level is 35

\footnotetext{
122 McGraw Hill, 1996, International Private Power Quarterly, Fourth Quarter.
} 
percent (average is 14 percent); capital must be registered to qualify for repatriation; and legislation restricts the activities of foreign enterprises. The country however, is interested in attracting foreign investment and several U.S. companies (AES Corp., Enron Corp., and Houston Industries Energy) have already been successful there. Brazil is a unique case for biopower because unlike most other countries, it has a tangible, historical dedication to renewable and biomass energy, but this is marred by the current instability of its overall economy. As the country explores more privatization efforts and the economy stabilizes, it will become one of the strongest markets for international biopower development.

\subsection{INDONESIA-Environment for Biomass Power}

Indonesia is also a strong candidate for biomass power. Its generating capacity in 1995 was $15.1 \mathrm{GW}$, and it is expected to add another $104 \mathrm{GW}$ of capacity by the year 2020. Thermal power plants generate 84 percent of Indonesia's power, 14 percent is generated by hydroelectric facilities, and the remaining 2 percent is from geothermal sources. As shown in section 6.2.1, Indonesia has good potential for biomass resources. On the investment side, independent power producers face a very good investment climate with benefits such as tax incentives, unlimited foreign participation in power projects, and a government commitment to increase rural electrification. These issues are discussed below.

\subsubsection{Biomass Resources}

Indonesia has good biomass technical potential, primarily due to its agricultural production residues. As explained in Chapter 2, the agricultural residues, industrial roundwood residues, and sugar mill technical potential numbers represent the maximum available resource, if all the residues were used for power generation. The energy crop figure represents the technical potential if three percent of all agricultural land were set aside for growing these crops.

Agricultural production residues:

Industrial roundwood residues:

Energy crops:

Power from sugar mills:
$8.8 \mathrm{GW}$
$4.3 \mathrm{GW}$
$3.2 \mathrm{GW}$
$0.4 \mathrm{GW}$

\subsubsection{Examples of Biomass Power Efforts}

The government is researching the use of biogas to electrify isolated villages. Biomass and fuelwood are already estimated to meet 80 percent of the energy needs of rural Indonesian households. ${ }^{123}$ The industrial sector uses 12 percent of the total biomass used in the country, and several biomass gasifiers exist in areas where the wood industry is concentrated. Specific biomass gasification activities were undertaken in the 1980s: in 1987, the government mandated that ten Indonesian-manufactured biomass gasifiers be placed in field operation as pilot projects; also in 1987, several Italian gasifiers were demonstrated at a number of forest/wood industry sites; from 1984-87, USAID supported a project to implement several gasifiers in rural cooperative applications; and, since 1988, the government established agreements with Germany, New Zealand, and the Netherlands to allow them to introduce their gasifiers in Indonesia.

${ }^{123}$ American Embassy-Economic Section, Jakarta, 1992, Indonesia's Electric Power Sector, January, p.21. 


\subsubsection{Economic and Investment Climate Cli $^{124}$}

As one of Asia's success stories, the Indonesian economy has maintained an economic growth rate of between 6-7 percent in the early 1990s. The industrial sector accounts for approximately 42 percent of GDP, and has moved towards more technology-intensive products, which increases its demand for power. Indonesia's economic growth has also spawned a greater demand for electricity from the residential sector.

Indonesia has one of the top investment climates for independent power projects. The government offers the following incentives: tax incentives and unlimited foreign participation in power projects; electricity tariffs fixed in U.S. dollars; foreign exchange allowed to flow freely; Indonesian partners' minimum holding in joint ventures is only 5 percent; and an aim to raise village electrification from 49 percent to 79 percent in 1998-99. The investment barriers are fairly muted and are outweighed by the incentives. They include: no guarantees on capital investment or debt repayments made by the private sector; a shortage of technical labor; and long negotiation periods.

\begin{tabular}{|l||}
\hline \\
INDONESIA \\
Incentives for Private Power Development \\
- $\quad \begin{array}{l}\text { unlimited foreign participation in power projects } \\
\text { tariffs fixed in U.S. dollars } \\
\text { foreign exchange allowed to flow freely } \\
\text { aim to raise village electrification to } 79 \%\end{array}$ \\
Barriers to Private Power Development \\
no guarantees on capital investment or debt \\
repayments made by private sector \\
long negotiation periods
\end{tabular}

Indonesia is rated as having a very good investment climate for independent power producers. It has a good overall credit rating, a growing economy, and liberal financial incentives. The government's energy strategy is to focus on hydroelectricity, gas, geothermal, and coal rather than on other renewables such as biopower. The oil and gas industries are significant drivers of the Indonesian economy; together, these sectors account for more than 20 percent of the country's export income. ${ }^{125}$ Therefore, as in India and China where competing fuels drive the power sector, biopower in Indonesia will fare best in niche markets. The country's excellent foreign investment climate and commitment to rural electrification can further justify a developer's interest in these niche markets.

\subsection{PHILIPPINES-Environment for Biomass Power}

The Philippines rounds out the group of top targets for biomass power development, mainly due to its positive investment climate. Its generating capacity in 1993 was $6.5 \mathrm{GW}$, and it is expected to add another $92 \mathrm{GW}$ of capacity by the year 2025. At $6.5 \mathrm{GW}$, the generating capacity of the Philippines is actually quite small; it is less than a hundredth of that of the U.S., and less than half the capacity of Indonesia. However, the country's power generation portfolio is much more evenly distributed among renewable and fossil-fired fuels. Hydroelectric (33 percent) and geothermal (14 percent) sources provide 47 percent of the country's power, while fossil-fired power provides the other 53 percent. As shown in section 6.3.1, Philippines has adequate potential for biomass resources. On the investment side, private power producers

\footnotetext{
${ }^{124}$ McGraw Hill, 1996, International Private Power Quarterly.

${ }^{125}$ Qoyum, A., 1997, "Forum on World Bank Role in Oil and Gas Sector: Indonesian Gas Development," March, p.3.
} 
face a very good investment climate with benefits such as no caps on rate of return, tariffs set in U.S. dollars, and a recently enacted law that streamlines the private power development process. These issues are discussed below.

\subsubsection{Biomass Resources}

The Philippines has adequate biomass technical potential, mainly due to its agricultural production residues. As explained in Chapter 2, the agricultural residues, industrial roundwood residues, and sugar mill technical potential numbers represent the maximum available resource, if all the residues were used for power generation. The energy crop figure represents the technical potential if three percent of all agricultural land were set aside for growing this crop.

Agricultural production residues:

Industrial roundwood residues:

Energy crops:

Power from sugar mills:
$2.5 \mathrm{GW}$
$0.7 \mathrm{GW}$
$1.0 \mathrm{GW}$
$0.3 \mathrm{GW}$

\subsubsection{Examples of Biomass Power Efforts}

The Philippine Dendrothermal Power Program is one of the few large-scale energy plantation efforts in the world. Established in 1979 to help reduce the dependence on foreign oil, the program aimed to use smallscale steam electric power plants to produce electricity from biomass. The program did not meet expectations; of the 217 power plants that were to be completed by 1987 , only nine were operational by the mid 1980s. This was mainly due to the fact that the cost of fuelwood production was typically higher than the price of wood purchased on the open market.

\subsubsection{Economic and Investment Climate ${ }^{I 26}$}

Reforms under President Ramos' administration have created a favorable business environment for private power development. Examples include: no caps on the rate of return; tariffs set in US dollars; a recently enacted law that streamlines the private power development process; foreign investors allowed to lease land up to 75 years; a government-formed, $\$ 100$ million-financed fund to accelerate international private power projects; a government priority for rural electrification; and government support for cogeneration. Investment barriers consist of: a temporary moratorium on new projects greater than $100 \mathrm{MW}$ due to over-capacity; and at the end of their lease, BOTs must transfer their plants to in-country operations.

\begin{tabular}{|l||}
\hline \multicolumn{1}{|c||}{ PHILIPPINES } \\
Incentives for Private Power Development \\
- $\quad \begin{array}{l}\text { no caps on rate of return } \\
\text { tariffs fixed in U.S. dollars } \\
\text { foreign investors allowed to lease land up to } 75 \\
\text { years } \\
\text { - } \quad \text { 100 million government fund for private power } \\
\text { projects } \\
\text { rural electrification is a priority } \\
\text { Barriers to Private Power Development } \\
\text { temporary moratorium on new projects greater } \\
\text { than 100 MW due to overcapacity } \\
\text { BOTs must transfer plants to in-country } \\
\text { operations at end of lease }\end{array}$ \\
- $\quad$.
\end{tabular}

\footnotetext{
${ }^{126}$ McGraw Hill, 1996, International Private Power Quarterly.
} 
Overall, the Philippines has a good investment climate for international power, albeit in the medium to long term, because of its strong overall credit rating, growing economy, abundant skilled labor, rural electrification priority, and liberal financial incentives. Due to limited resources, however, its biopower potential is more piecemeal, where the greatest opportunities will probably be in rural electrification. 


\subsection{TECHNOLOGY DISCUSSION}

This section will expand on the potential biopower opportunities outlined in chapter 2 . It begins with a discussion of co-firing and continues with repowering and distributed generation. Due to a lack of country-level data, waste-to-energy is not covered in this chapter.

\subsection{Co-firing}

Co-firing is the co-combustion of different fuels in the same boiler. Biomass is a well-suited resource for co-firing with other solid fuels, primarily coal, due to general similarities in storage, handling, and stack gas clean-up requirements. Co-firing is a replacement option for existing fuel capacity, and is not a capacity expansion option like repowering. A biomass co-firing retrofit in an existing coal boiler will require modifications or additions to fuel handling, storage and feed systems. Usually, these can be accomplished by using commercially available equipment. Co-firing utilizing biomass has been successfully demonstrated throughout the world and is currently practiced in the full range of coal boiler types, including pulverized coal boilers, stokers, cyclones, and bubbling and circulating fluidized beds. This section will provide a general background on biomass co-firing and some insight into how these issues apply specifically to major international markets such as China and India.

\section{Benefits of Co-firing}

The current fleet of coal-based electricity generators are producing about 36 percent of the world's power supply ${ }^{127}$ or about $1,023 \mathrm{GW}$ of generation capacity. ${ }^{128}$ These power plants are experiencing increasing pressure to reduce operating costs as well as $\mathrm{SO}_{2}, \mathrm{NO}_{\mathbf{x}}$, and possibly $\mathrm{CO}_{2}$ emissions. Co-firing biomass at these existing coal-fired power plants is one possible cost-effective environmental compliance option. Coupled with the disposal requirements faced by industrial generators of biomass residues (generally clean wood byproducts or remnants), co-firing offers the potential for solving several problems at potentially modest investment costs. For most U.S. power plants that have implemented biomass co-firing systems, reducing production costs has been the primary driver. Co-firing installations are presently found in areas where the cost of coal is high relative to the cost of available biomass residues. Thus, the key to co-firing projects has been locating cheap, reliable supplies of biomass in quantities large enough to pay off the retrofit investment in an acceptable period of time ( 3 years or less in most cases).

The list of potential benefits associated with biomass co-firing includes:

- $\quad$ Reduced Fuel Costs--Savings in overall production costs can be achieved if inexpensive biomass fuel sources are available. The price of biomass, on a heat basis (cost per MMBtu), must be low enough compared to the price of the existing coal supply to compensate for 1) moderate increases in operating costs incurred due to the addition of biomass storage and processing equipment, and 2) slight decreases in boiler efficiency. Under most circumstances, boiler efficiency will decrease as the volume of biomass increases (due to the higher moisture content of biomass relative to coal). This may not be the case in countries like India which use large amounts of brown coal for electricity generation. Poor quality brown coal is characterized by high moisture and ash contents and low heating values relative to bituminous coals commonly encountered in the U.S. Poor quality coal leads to less efficient boiler operation. Hence, boiler performance degradation

\footnotetext{
${ }^{127}$ Energy Information Administration, 1996, International Energy Outlook 1996 with Projections to 2015, DOE/EIA-0484(96), May, p. 77
} 
experienced due to co-firing biomass in an existing boiler for which the primary fuel is brown coal will be less dramatic. In general, the amount of biomass used should be limited to result in boiler efficiency decreases of less than $1 \%$ (the amount of biomass allowable to maintain efficiency decreases of less than $1 \%$ will depend on the quality of the biomass fuel, particularly its moisture content). Based on co-firing experience and testing in the U.S., efficiency losses can be limited to about 1 to 2 percent for co-firing biomass with 40 to 50 percent moisture content, at rates as high as 10 percent of the total heat input. ${ }^{129}$ Biomass fuel supplies will need to be available at prices 20 percent or more below current coal prices.

- Market-Ready Renewable Energy Option--For co-firing, technology development is much less of an issue than resource economics and availability. Biomass co-firing with coal is practiced at a handful of utility-scale boilers (see Volume I, Chapter 7) and at many industrial sites, primarily in the forest products industry. Retrofits require commercially available fuel handling and boiler equipment. Engineering and design issues are well understood.

- Implementation Costs/Requirements--Co-firing system retrofits require small capital investments relative to most other renewable power generation technologies. Costs of $\$ 100$ per $\mathrm{kW}$ of biomass power can be achieved for stokers, fluidized beds, and cyclones. Retrofits at a pulverized coal (PC) boiler typically range from $\$ 300$ to $\$ 500$ per $\mathrm{kW}$ of biomass power. This is significantly higher than the cost of the other boiler types, primarily due to the increased fuel processing equipment required to reduce the biomass particles to a size small enough to allow complete burn-out in a PC boiler.

- Continuous, Base-Load Power Generation Capability from Renewable Fuel Resources-Unlike most renewable electricity generation technologies, biomass-based systems are capable of operating in a base-load capacity and therefore have the advantage of higher capacity factor operation. This helps provide quicker pay-offs of the initial capital investment.

- Flexible Fuel Option for Intermittent Use--The systems described in this report are designed to be flexible. They can be run during selected times or shifts. The biomass-fired systems are independent of the coal-fired system. If problems arise with the biomass system, full power production can still be achieved using coal only.

- Atmospheric Environment Improvement--Atmospheric environmental benefits associated with using biomass resources to replace fossil fuels (primarily coal) include reductions in net emissions of greenhouse gases (carbon dioxide, $\mathrm{CO}_{2}$ ) and acid rain precursors (sulfur dioxide, $\mathrm{SO}_{2}$, and possibly nitrogen oxides, NOx). Sulfur dioxide and net carbon emissions are reduced in proportion to the amount of heat input obtained from biomass. For India, where coal used for power production is, on average, higher in sulfur than U.S. coal on an energy content basis, ${ }^{130,131}$ the sulfur reduction benefits associated with replacing coal with biomass will be greater. Coal in China is typically low in sulfur content. These benefits apply for all biomass power technology options, but there are additional benefits unique to co-firing. Because biomass absorbs as much

\footnotetext{
${ }^{129}$ Tillman, David A., Dale Bradshaw, and Evan Hughes, 1996, Fuel Blending and Switching for NOx Control Using Biofuels with Coal in Cyclone Boilers, Foster Wheeler Environmental Corp./Tennessee Valley Authority/ Electric Power Institute.

${ }^{130}$ U.S. Department of Energy, 1994, Foreign Markets for U.S. Clean Coal Technologies, DOE/FE-0317, May 2, p.3-35.

${ }^{131}$ Office of Technology Assessment, 1992, Fueling Development: Energy Technologies for Developing Countries, OTA-E-516, pp.246.
} 
carbon dioxide during its growing cycle as is emitted from a boiler when it is burned, it generates nearly no net $\mathrm{CO}_{2}$ emissions when biomass production is undertaken on a sustainable or "closedloop" basis. This makes biomass one of the most practical strategic options for complying with restrictions on generation of greenhouse gases.

- Landfill Reduction--Using urban wood residues as a fuel reduces landfill material and consequently extends landfill life. For industries served by the utilities, rising tipping fees and restrictions on landfill use represent an opportunity for the power company to assist its industrial customers while obtaining a low-cost alternative fuel. Firing biomass in boilers with pollution control can reduce burning of wood residues in uncontrolled furnaces (e.g., wigwam burners) and hence provide another means of reducing emissions.

\section{Key Factors to Evaluate}

\section{Keys to a Successful Co-firing Project}

From a station operating and performance perspective, the goal for a successful biomass co-firing project is to obtain cost and emissions reductions. The objectives of a co-firing project should include:

- obtaining sufficient supplies of biomass fuels at prices $20 \%$ or more below current coal prices,

- designing and installing biomass fuel receiving, processing, and combustion systems to minimize boiler efficiency losses to less than $1 \%$,

- $\quad$ providing reliable and automated operation,

- having no impact on equipment and operations downstream of the boiler, and

- obtaining value from emission reductions in $\mathrm{SO}_{2}, \mathrm{CO}_{2}$, and/or $\mathrm{NOx}$.

\subsection{Repowering}

Repowering can briefly be defined as the replacement or augmentation of an existing steam generator for the purpose of increasing capacity, efficiency, or both. Repowering typically also involves decreased emissions, either on an incremental or absolute basis. There are a number of different means by which repowering can be accomplished. ${ }^{132}$ This report will focus on the most popular utility-scale option (Substitute Combustion Turbine/Heat Recovery Steam Generator (CT/HRSG)) and two other options that may be well suited for biomass applications (Feed Water Heater Repowering (FWHR) and Cold WindBox Repowering (CWBR)). The intention of these, and most repowering projects, is to increase the power plant's performance while leveraging previous investments in existing equipment and infrastructure.

Many factors determine the suitability of a power plant to undergo repowering. Most are technical or physical and are unaffected by specific in-country policies. The notable exceptions will be permitting requirements. How each of these items is addressed will indicate the form of repowering appropriate for any given power plant. These criteria are:

1) The current and desired capacity/heat rate of the unit

2) The current and target production costs for the unit

3) The emission requirements of the unit and corresponding permit requirements

4) Capital expenditures and budgetary constraints

5) The steam cycle configuration of the existing unit

${ }^{132}$ Antares Group Inc., Repowering Applications and Markets for Biomass Fuel Integration and Augmentation, July 22, 1996 
7) Current and desired fuel/fuel flexibility

8) The condition and age of any equipment to be retained

For countries seeking to rapidly expand their electricity generating capacity, repowering is an effective way to revitalize existing generating assets and lower power production costs. Additional results may also be realized: improved power station environmental profiles; incremental capacity at a reduced level of capital investment and risk; and increased plant efficiency. In many cases it should be possible to obtain these benefits with capital investments that are significantly reduced over greenfield projects.

Utilities and private power producers are targets for repowering. Industries that own cogeneration assets are also considering this move but generally with a different motivation. Their interest in repowering is usually motivated by the need to replace aging equipment and increase steam generation for expanded operations. In developing countries such as India and China, excess electricity may be a useful co-product that can be sold back to the grid.

Recent plans for international utility repowering projects include: ${ }^{133},{ }^{134}$

- $\quad$ Czech Republic - coal-fired cogeneration district heating station

- $\quad$ Belgium- two $44 \mathrm{MW}$ gensets for repowering project in Langerlo

- $\quad$ Phillippines - nuclear plant to be repowered with gas turbines and HRSGs

- China - conversion of simple cycle plant into combined cycle operation in Ahui Province

When incremental capacity is an objective, natural gas is the current fuel of choice in the power sector. This has also been a good choice for the cogenerating process industries given today's gas prices and system efficiencies. For biomass to be considered as a choice worthy of the investment and risk in a repowering project, it must provide a combination of the above benefits. The projected benefits of the biomass repowering option will probably have to exceed those realized through fossil-fired options (with natural gas setting the standard) to receive attention in the competitive markets now envisioned for the international power generation or cogeneration industry. Biomass may be a choice when:

- A plentiful supply of residue fuels is available at very favorable prices; and

- use of biomass as fuel will improve overall plant operations; and

- the benefits of "green" generation capability can be valued.

A few types of repowering that may be well suited for biomass applications are substitute CT/HRSG, FWHR, and CWBR. The first two are probably best suited for utility-scale applications, while the last option will be of interest to smaller industrial cogenerators. For reference, these options are outlined below.

\section{Substitute Combustion Turbine with Heat Recovery Steam Generator (CT/HRSG) - Natural Gas}

This method of repowering usually includes replacement of the existing boiler and relevant components of the steam cycle with a combustion turbine and HRSG system. Steam generated by the HRSG is then used by the retained steam turbine for power production. Currently, the CT/HRSG is the domestic power industry's primary choice for repowering and numerous facilities have already benefited from this

\footnotetext{
${ }^{133}$ Gas Turbine World, November-December 1996

${ }^{134}$ Gas Turbine World, January-February 1997
} 
technology. For units smaller than $150 \mathrm{MW}, \mathrm{CT} / \mathrm{HRSG}$ is considered the repowering option of choice. This option provides excellent capacity and heat rate improvements and has been proven to be a sound economic investment. In fact, replacement of the existing boiler with a CT/HRSG system may reduce heat rates by 20 percent and triple overall capacity with a capital investment in the $\$ 450$ to $\$ 850$ per kW range in the U.S. (It is because of the enormous increases in capacity that substitute CT/HRSGs may not be acceptable for larger facilities. In some cases, the increased capacities may overwhelm the current power transmission infrastructure or exceed power demand. This may prove less economic, and therefore, less desirable.) Additionally, because the CT/HRSG replaces the existing boiler, this option is not restricted based on the type of fossil fuel currently being used. Modifications to the existing steam cycle usually center on matching the output steam conditions of the HRSG to the inlet conditions of the retained steam turbine. Overhaul of the steam turbine (installation of improved blading) and generator (rewinding) are often required, and in many cases the original feedwater heating extractions are eliminated.

\section{Combustion Turbine / Feedwater Heater Repowering (CT/FWHR) - Natural Gas}

$\mathrm{CT} / \mathrm{FWHR}$ actually belongs to a group of repowering options known as parallel cycles. These cycles are usually characterized by configurations that allow the repowering components (most significantly the combustion turbine) to be isolated from the existing steam cycle and the cycles to be run in parallel. This increases plant flexibility and reduces operational risk.

CT/FWHR is usually considered to be technically the least restrictive repowering option. This method recovers the exhaust heat from the combustion turbine to heat boiler feedwater. This allows the feedwater heater steam extractions from the existing steam turbine to be closed, allowing for more steam flow and increased power from the steam turbine. The success of this repowering option is highly dependent on the ability of the retained steam turbine to accept the additional steam flow. Feedwater heating recovery is best suited for larger, more modern steam plants. However, modifications to the facility are less extensive than those required for other forms of repowering, with a majority of the changes limited to feedwater systems. Capacity and heat rate improvements for CT/FWHR are more modest than those realized by CT/HRSG, but installation costs are also reduced. CT/FWHR has the potential to represent the lowest capital investment repowering opportunity with cost estimates ranging from $\$ 100$ to $\$ 600$ per $\mathrm{kW}$ in the U.S.

\section{Combustion Turbine / Cold WindBox Repowering (CWBR) - Natural Gas}

Cold WindBox Repowering may offer an option particularly well suited to smaller, industrial cogeneration facilities using packaged boilers. Co-generation applications are usually driven by a plant's thermal requirement. In this option, the existing boiler is modified to act as a HRSG using the exhaust of a gas turbine. This option is similar to Hot WindBox Repowering (CT/HWBR) except that no air preheater is used, a feature typical of smaller scale systems. In addition to adding a combustion turbine to the cycle, modification to the HRSG (modified existing boiler) will be probably be required to allow for supplemental firing. Unless supplemental firing capacity is added, most cogeneration plants will not be able to support daily swings in steam requirements without an auxiliary boiler. ${ }^{135}$ Estimates for CWBR at an industrial scale are on the order of $\$ 600-\$ 800 / \mathrm{kW}$ in the United States.

Using biomass as the repowering fuel in all these options does introduce some additional complications not described for the natural gas cases.

1996.

${ }^{135}$ Vetterick, R.C., et al., Comparative Evaluation of Cogeneration Cycle Alternatives, Babcock and Wilcox Technical Paper, June 
1) Using biomass in these cycles will most likely require a gasification plant (some technologies such as direct-fired combustion turbines are already being demonstrated but wide applicability to a variety of feedstocks still represents a significant challenge). The capital costs of commercial biomass gasification plants are still speculative. However, they will represent a significant addition to the overall costs of the repowering. Further, gasification plants above $100 \mathrm{MW}$ in size are undemonstrated and biomass integrated gasification cycles are likely to be limited to below that size due to residue resource constraints (although the use of energy crops may eventually alleviate that problem). Overall plant efficiencies for biomass combined cycle power plants are also expected to be somewhat lower than their natural gas-fired brethren.

2) Feedstock must be available at costs consistently and markedly below local natural gas prices in order to pay out the increased capital costs associated with gasification.

3) It seems unlikely that units supplied by an existing natural gas supply infrastructure (either by virtue of being gas-fired or because of multi-fuel capability) will choose biomass gasification over natural gas unless significant operational synergies can be realized by doing so. Therefore, coalor oil-fired units are the most practical targets for utility units, while industrial process industries such as those used in the pulp and paper industry are more likely targets in the cogeneration market.

Limited specific information is available on non-domestic powerplants. Therefore, it is difficult to estimate the extent to which biomass repowering options could be employed worldwide. However, dividing the repowering opportunities into two groups (utility repowering and industrial facility repowering) offers some additional insight.

\section{The International Utility Sector and Biomass Repowering}

Certain truths are global. There are power generators almost everywhere seeking ways of reducing production costs and meeting new capacity demands while minimizing capital investments. Repowering with natural gas will continue to be an important strategy for meeting these objectives. Repowering using biomass in the utility or IPP sector will be more of an uphill battle. Even assuming that the technology for gasification comes of age in short order, project developers will be faced with a host of additional obstacles. In India, for example, biomass resources are already considered a commodity and often have value in excess of that which can be afforded by the power generation market. Large, utility-scale biomass repowering projects may not be able to afford sufficient biomass feedstock to make a project viable. Even energy crop production is somewhat speculative due to the estimated high production costs and competing uses for land. A great deal of substitute CT/HRSG repowering of any type which eliminates the need for coal may also experience strong resistance, and negatively impact the economy in other areas such as jobs. As noted previously, India's coal industry is its single largest employer.

Repowering configurations that augment existing steam generation capacity (FWHR, as an example) instead of replacing it may offer some solutions. Retaining coal-fired capacity while adding smaller more efficient and environmentally suitable generation using biomass-powered combustion turbines may be attractive. Sites will necessarily have to meet some strict technical criteria, but these cycles offer the potential for lower absolute investment costs, increased plant operational flexibility, and comparatively low operational risk. These cycles do not alter the plant's need for coal and may address political and social concerns of many developing countries. In the near term, augmentation repowering configurations may be best suited for the introduction of emerging biomass technology. The ultimate acceptance of repowering using biomass in the utility sector will depend on resource availability, technology improvements, and 
the extent to which potential benefits (environmental neutrality, local sustainability) and drawbacks (displacement of existing jobs) are valued.

With respect to repowering the utility/IPP sector, it should be noted that repowering does not alleviate the need for developing transmission and distribution infrastructure. The cost of repowering units that are on the central grid will necessarily involve new investment in T\&D. The added expense of this infrastructure may steer developing countries towards repowering units capable of supplying captive plants with dedicated power and towards units that can act in a mini-grid capacity or as distributed generation.

\section{The International Cogeneration Sector and Biomass Repowering}

As with the utility sector, it is difficult to characterize international cogenerators as a group. There is limited micro-level information available that would be useful in determining an accurate market potential for repowering units in this sector. However, it is known that countries like India and China that have large coal reserves rely heavily on that resource for power generation in industries that cogenerate as well as in the power generation sector. Specific breakouts of coal use by industry were not available, but 41 percent of India's $\mathrm{CO}_{2}$ emissions from coal combustion were generated by industry in $1992 .{ }^{136}$ Similarly, in 1992, Chinese industry was responsible for 45 percent of $\mathrm{CO}_{2}$ emissions from coal. By contrast, power plants were responsible for 30 percent of $\mathrm{CO}_{2}$ emitted from the combustion of coal. ${ }^{137}$

Repowering industrial cogeneration facilities does present some unique challenges and opportunities for biomass. Industrial processes requiring cogeneration and handling large amounts of biomass residues seem to offer the potential for handling and storage synergies. These industries, including pulp and paper manufacturing and sugar refining may offer production integration benefits as well. The opportunity for making major improvements in India and China's pulp and paper industry appears substantial.

The technical level at which pulp and paper plants are operating in these two countries is far below those of developed countries. ${ }^{138}$ In India the pulp and paper industry is the sixth largest consumer of energy in the country and energy accounts for approximately 25 percent of the total manufacturing costs. ${ }^{139}$ For perspective, the heat-to-power demand for the paper industry is around five. The break-even value for this indicator is approximately 2.5 , and development of technology in the pulp and paper industry in these countries has been essentially static since the $1950 \mathrm{~s}$.

Repowering these plants to more effectively use their biomass resources may help the industry improve efficiencies, prepare for the anticipated growth in paper consumption that is expected for these countries, and potentially generate excess electricity for sale to the grid. Initially, repowering projects may focus on modifying existing boilers used to generate steam for power in a manner consistent with CT/CWBR. Later, developing technologies such as black liquor gasification may provide an opportunity for pulp and paper mills worldwide to more completely integrate biomass power production with the entire pulp and paper manufacturing process.

\footnotetext{
${ }^{136}$ World Energy Council, 1995, National Energy Data Profile, India.

${ }^{137}$ World Energy Council, 1995, National Energy Data Profile, China.

${ }^{138}$ Ishiguro, M. and T. Akiyama, 1995, Energy Demand in Five Major Asian Developing Countries-Structures and Prospects, World

Bank.

${ }^{139}$ Tata Energy Research Institute, 1996, TEDDY 1995/96, p. 144
} 
Black liquor gasification is especially interesting because it represents an integrated approach to overall pulp and paper plant improvement that includes chemical recovery processes and steam/power production. Black liquor is an aqueous solution rinsed from pulp. It contains wood lignin, organic material, and inorganic compounds. ${ }^{140}$ Black liquor gasification is intended to accomplish the same objectives as conventional chemical recovery processes used in the pulp and paper industry: recover inorganic compounds for re-use and convert waste organic compounds into thermal energy for use in the mill (either for electricity or as process steam) ${ }^{141}$ However, black liquor gasification will allow the use of gas turbines for energy and steam production instead of recovery boilers. Gas turbine based steam/power cycles are likely to be more efficient than steam cycles using chemical recovery boilers. Repowering using black liquor gasification will be accomplished either by replacing aging recovery boilers or as a strategy for incrementally adding plant processing capability. The decision to design systems to supply excess power to the grid will be determined by the economics of specific situations. However, the current state of the pulp and paper industry in China and India and their need for new, reliable capacity may provide a powerful incentive to consider this opportunity.

Ultimately, repowering industrial power plants with biomass will depend on the desire of these industries to invest capital to improve efficiencies and increase production, and like utility generators or IPPs, their ability to obtain steady, low-cost supplies of biomass. Further, it appears that certain industries (pulp and paper and sugar) in some developing countries are in such a state as to require such investments if they are to become anything more than marginally competitive in the global market. Repowering, for them, may offer a lower cost alternative and incrementally more affordable alternative than greenfield development.

\subsection{Distributed Generation}

Many of the perceived benefits of distributed generation in the U.S. are also true for many developing countries, including China and India. Most are directly related to avoiding the investment associated with large-scale greenfield plant development and subsequent grid extension activity. These benefits include:

- $\quad$ Avoidance of T\&D capital costs and reduced O\&M expenses (especially high in India) ${ }^{142}$

- Smaller absolute investments in power projects - lower financial risk

- The ability to design systems that match load profiles more closely

In countries with highly unreliable power generation (like India) some additional benefits could also include:

Increased industrial productivity due to increased electrical system reliability

- Stimulation of rural economies through rural electrification

However, there are some potential concerns with respect to distributed generation that may be especially significant when considering biomass distributed generation.

- Higher investment costs on a $\$ / \mathrm{kW}$ basis due to inverse economies of scale. This may occur with respect to equipment costs or costs associated with permitting. As an example, it may take just as

\footnotetext{
${ }^{140}$ Steam-Its Generation and Use, 1992, Babcock \& Wilcox, Fortieth Edition.

${ }^{141}$ Finchem, K.J., 1995, Black Liquor Gasification Research Yields Recovery Options for the Future, Pulp and Paper, November, p.49

${ }^{142}$ Forthcoming NREL Publication, “Comparison of Large Central and Small Decentralized Power Generation in India," 1997
} 
much time an effort to get approval for construction for a $10 \mathrm{MW}$ facility as it would for a 100 MW facility.

- $\quad$ Need for local operating and maintenance

- $\quad$ Need for local fuel supply (competing uses for land and residues)

- Rural electrification desired in many countries but subsidy structures are such that independent project developers would not receive adequate returns from revenues collected from highly subsidized agricultural sector. In this respect China appears to be a better investment for private power developers than India.

Several biomass technologies are being developed that may be well suited for serving the international distributed generation market. These include Stirling engines, direct-fired combustion turbines, fuel cells, and BIGCCs. A summary of potential size applicability for each of these technologies is given below. A more detailed description of each of these technologies can be found in Volume I of this report.

EXHIBIT 7.3-1

Summary of Economic Size Ranges for Each Technology

\begin{tabular}{|l|l|}
\hline DG Technology & Size \\
\hline Stirling Engine & Greater than $1 \mathrm{~kW}$, less than $100 \mathrm{~kW}$ \\
\hline Direct-fired Combustion Turbine & Greater than $5 \mathrm{MW}$, less than $25 \mathrm{MW}$ \\
\hline Fuel Cell* & Greater than $25 \mathrm{~kW}$, into the MW size \\
\hline BIGCC & Between 20 to $80 \mathrm{MW}$ \\
\hline \multicolumn{1}{|c|}{${ }^{*}$ Smaller fuel cells may be introduced as part of the transportation market }
\end{tabular}

There are several factors that must be considered when determining which technologies are best suited for a particular distributed biomass generation technology. These include the amount of power required to meet the needs of the end-use market, the load characteristics of the demand, the availability of feedstock, emission requirements, and process steam requirements. These are in addition to the social and economic concerns.

Each of these systems will probably find niche markets in which to play a role based on its technical and economic limitations. As noted earlier, BIGCCs used for repowering in the industrial cogeneration sector may provide opportunities to integrate plant processes. These types of systems are generally too large to serve rural villages so their use in providing power/steam to dedicated plants is more likely. Excess power could then be sold to the grid or in support of mini-grid applications. Direct-fired combustion turbines and fuel cells may also be better suited in this role. Stirling engines coupled with gasification have already been placed into service in India. Over 1,600 units with a cumulative capacity of $32 \mathrm{MW}$ of capacity were installed as of March 1995. ${ }^{143}$

An issue of ultimate importance with respect to biomass power in any country is the availability of biomass resources for use as fuel for these technologies. In this respect, the smaller technologies which can be

${ }^{143}$ Tata Energy Research Institute, 1996, TEDDY 1995/96, p. 117 
supported by small amounts of waste residues will have a considerable advantage in the rural sector. Competing uses for land (food crops for example) in the agricultural community may inhibit the use of significant acreage for production of energy crops. In fact, residues are likely to be used for home heating, or cooking. Implementing wide-scale distributed generation initiatives will take planning, capital and support from government policy makers. However, in the long run, biomass used in distributed generation applications may help stimulate the rural economy and provide an environmentally and economically viable alternative to grid extension. 


\subsection{POTENTIAL FINANCING SOURCES}

Although the traditional mode of financing for developing-country projects has been the multilateral lending agencies, they are not the only option available today. Intense competition for funds makes alternative sources more attractive. This chapter describes the government sources that help target project opportunities, and provide pre-project assistance, project financing, and insurance to developers interested in renewable power projects in the five countries targeted in this report. Information contained in these descriptions was obtained from two highly recommended sources:

Delphos, William A., 1996, Power Money: The International Business Executive's Guide to Government Resources, Renewable Energy Edition, sponsored by the US Export Council for Renewable Energy and US Agency for International Development (USAID).

USAID, Office of Energy and Infrastructure, 1993, Sources of Finance for Private Power Projects in Asia, Business Focus Series, January.

Since the international market is in a constant state of flux, the information outlined below should be considered a snapshot of the current standards and criteria facing developers. This is a good starting point, but there is no substitute for direct contact with the organizations of interest.

\subsection{Targeting Project Opportunities}

The following publications and/or databases provide useful information to assist the developer who is just beginning to enter the international power market. Most of the services are free or available at a nominal cost, so they are a good first step.

\section{Asian Development Business Opportunities}

A monthly publication from the ADB that lists all proposed projects, advance action on procurement, technical assistance projects, consultants recruiting, retroactive financing projects, procurement notices, and final contract awards. International subscription rate is $\$ 30$ per year.

Contact:

Asian Development Bank

6ADB Avenue, Mandaluyong City

0401 Metro Manila, Philippines

Tel: (63-2) 632-4444
Washington, DC office:

1730 Pennsylvania Ave., NW, Suite 975

Washington, DC 20006

Tel: (202) 347-0878

\section{Commerce Business Daily}

A daily publication of the Department of Commerce that contains international trade leads, commodity requirements of foreign governments, U.S. government procurement invitations, subcontracting leads, contract awards, sales of surplus property, and foreign business opportunities. Annual subscription is $\$ 324$ and six-month subscription is $\$ 162$.

\section{Contact:}

Superintendent of Documents

U.S. Government Printing Office

Washington, DC 20402

Tel: (202) 512-1800 


\section{Environmental Technology Network for Asia}

A free computer database managed by the USAID Center for Trade and Investment Services that disseminates environmental opportunity notices and matches them with appropriate U.S. environmental companies registered with the database. Within this network, the U.S. - Asia Environmental Partnership Trade Leads provides detailed information on renewable energy projects that have been gathered by its Technology Representatives.

\section{Contact:}

Center for Trade and Investment Services

515 22nd St., NW

Room 100 SA-2

Washington, DC 20523

Tel: (202) 835-0333

\section{Financing Renewable Technologies}

A handbook that provides a brief overview of U.S. government agency export-support programs. It contains a form that renewable energy firms can use to make a preliminary application for export assistance.

\section{Contact:}

U.S. Export Council for Renewable Energy

122 C St., NW, Suite 520

Washington, DC 20001

Tel: (202) 383-2550

\section{International Business Opportunities Service (IBOS)/Monthly Operational Summary (MOS)}

The IBOS provides advance information on World Bank project funding and potential contracts in manufacturing, civil works, and consulting. It is the primary source of project-specific information on World Bank financing under consideration and on potential procurement opportunities. Annual subscription is $\$ 200$. The MOS contains status updates of every project under consideration for financing by the World Bank, from the earliest stages through approval. Annual subscription is $\$ 250$.

\section{Contact:}

World Bank Publications

P.O. Box 7247-7956

Philadelphia, PA 19170

Tel: (201) 476-2192

\subsection{Pre-Project Assistance/Feasibility Studies}

Once potential opportunities have been targeted, the developer has to assess the commercial feasibility of expanding overseas. However, the costs associated with evaluating an international market can be enormous. This section provides a list of sources that can help the developer share the cost of developing international power projects. 


\section{Asia Alternative Energy Unit (ASTAE)}

Established by the World Bank in 1992, ASTAE's objective is to identify and prepare renewable energy and energy efficiency components for World Bank/Global Environment Facility-supported projects in Asia. It designs and implements training, helps formulate alternative energy policies and strengthens institutional capabilities, collaborates with donor agencies, and mobilizes technical assistance funds.

\section{Contact:}

Asia Alternative Energy Unit

The World Bank

1818 H St., NW

Washington, DC 20433

Tel: (202) $458-1405$ or $458-1434$

\section{$\underline{\text { Asia-Pacific Initiative }}$}

A US/ECRE program designed to identify and secure sources for funding for projects which utilize U.S. renewable energy/energy efficiency technologies to help meet Asia's growing electric power needs in an environmentally sensible manner. It focuses on India, Indonesia, and the Philippines.

\section{Contact:}

U.S. Export Council for Renewable Energy

122 C St., NW

Fourth Floor

Washington, DC 20001

Tel: (202) 383-2550

\section{Asian Development Bank (ADB)}

ADB has funded numerous technical assistance projects in the Asian region, generally for industrial development or major infrastructure planning in its member countries. Its lending has historically been at the government level, but there may be a greater focus on private power. Technical assistance includes feasibility studies for specific projects in an overall development plan. Interested firms must submit bids for evaluation under an international competitive award process. ADB maintains field offices in Bangladesh, India, Indonesia, Nepal, and the South Pacific.

\section{Contact:}

Asian Development Bank

6ADB Avenue, Mandaluyong City

0401 Metro Manila, Philippines

Tel: (63-2) 632-4444
Washington, DC office: 1730 Pennsylvania Ave., NW, Suite 975

Washington, DC 20006

Tel: (202) 347-0878

\section{$\underline{E \& C o .}$}

E\&Co.'s mission is to promote developing country energy enterprises that create economically selfsustaining energy projects, use environmentally superior technologies, and produce a more equal distribution of energy. It is a non-profit energy investment service that offers four basic services to energy entrepreneurs: small loans, technical assistance, intermediary services, and direct investment, for the following types of enterprise activities: implementation innovation, technology innovation, rural energy- 
community development, and financing innovations. Recent projects include a $1 \mathrm{MW}$ biomass power plant in Bolivia, a home photovoltaic project in China, and a rural biogas-based energy enterprise in India.

Contact:

E\&Co.

Energy House

383 Franklin St.

Bloomfield, NJ 07003

Tel: (201) 680-9100

\section{Energy Management Consultation and Training (EMCAT)}

This India-based project helps improve management efficiency of the energy sector. EMCAT trains Indian energy officials and engineers and helps in modernizing power systems, with the assistance of U.S. private expertise and equipment.

Contact:

General Manager, Technology

Industrial Development Bank of India

IDBI Tower Cuffe Parade

Bombay - 400005 India

Tel: (91-22) 218-9111

Export-Import Bank of the U.S. (ExIm Bank) Engineering Multiplier Program

This program offers fixed rate loans and guarantees to foreign buyers in an attempt to expand the sales of project-related feasibility studies and pre-construction services in order to increase the potential for U.S. exports. All services must be related to a project for which substantial additional U.S. exports will be needed once construction begins. Finance will be provided for up to $\$ 10$ million of U.S. export value.

\section{Contact:}

Export-Import Bank of the U.S.

Engineering Multiplier Program

811 Vermont Ave., NW, Room 1167

Washington, DC 20571

Tel: (202) 566-8802

Inter-American Development Bank (IDB)

IDB funds technical assistance projects in Latin America, primarily for industrial development or major infrastructure planning. It is the principal source of external finance for most Latin American countries. Interested firms must submit a bid under a competitive award process coordinated between the host government and IDB.

\section{Contact:}

Inter-American Development Bank

1300 New York Ave., NW

Washington, DC 20577

Tel: (202) 623-1000 


\section{Indian Renewable Energy Development Agency (IREDA)}

IREDA was established in 1987 as an autonomous public sector corporation with the following objectives: 1) to operate a revolving fund for promoting and developing renewable energy sources; 2) to give financial support for projects that generate or conserve energy through renewable means; 3 ) to finance projects in rural areas. IREDA provides loans, assists with project preparation, and assists states with preparing project pipelines. It receives funds from the Government of India, by issuing bonds, and from multilateral and bilateral donors. Interest rates range between 2.5 and 15.5 percent with terms up to 10 years. As of March 1991, the agency had a cumulative loan portfolio of $\$ 16.14$ million spread over 125 projects.

\section{Japan Industrial Cooperation Agency (JICA)}

JICA is an official agency of the Japanese government that sponsors and conducts surveys and studies for public projects in developing countries, primarily for infrastructure development in Asia. It conducts master planning, integrated development studies, feasibility studies, resource surveys, groundwater surveys, and topographical and oceanographic surveys. Access to these programs will be decided on a case-by-case basis, as no fixed procedure yet exists for including U.S. firms in JICA programs.

\section{Contact:}

Japan Industrial Cooperation Agency

90019 th St., NW

Suite 350

Washington, DC 20006

Tel: (202) 457-0412

\section{Renewable Energy Pre-Investment Support (REPS) Fund}

The REPS Fund is managed by Winrock International and is a grant program that assists private firms in evaluating opportunities to develop renewable energy projects in developing countries. It aims to stimulate investments in renewable energy projects that minimize rural dependence on imported and domestic fossil fuels, enhance national energy diversity, and encourage environmentally sound management of natural resources.

\section{Contact:}

Renewable Energy and the Environment Project

Winrock International

1611 North Kent St., Suite 600

Arlington, VA 22209-2134

Tel: (703) 525-9430

\section{Trade in Environmental Services and Technology Project (TEST)}

This project addresses pollution problems in India with market-oriented solutions. TEST can: 1) help renewable energy firms identify and contact interested and qualified Indian commercial partners; 2) assist in meeting with prospective clients and partners; 3) provide ongoing, in-depth assistance to conclude transactions and develop long-term business relationships with Indian firms; and 4) through the Industrial Credit and Investment Corporation of India, offer loans and conditional grants for selected environmental projects. 
Contact:

TEST Program Manager

Sanders International

1616 P St., NW, Suite 410

Washington, DC 20036

Tel: (202) 939-3486

\section{United Nations Technology Transfer Programs}

This program funds feasibility activities for certain key industrial sectors including renewable energy and power generation from indigenous fuels. The request must be from the appropriate host government entity and there is no fixed amount of funding or formal procedure set up for review and approval. Applicants must be members of the U.N.

\section{Contact:}

Mr. Edward C. Mattes, Jr.

Manager, Division for Private Sector

UNDP-UNISTAR

One U.N. Plaza (TM-908)

New York, NY 10017

Tel: (212) 697-4593

\section{USAID Bureau for Private Enterprise (PRE)}

The PRE Office of Capital Projects and Engineering is a central source of expertise, information, policy guidance, and oversight of all engineering matters pertaining to USAID capital projects in developing countries. It devises and implements new methods and sources of financing and provides a range of engineering and program development services to missions. The Private Sector Investment Program (PSIP) assists private sector development through direct loans or loan guarantees for introduction of new financial market instruments and concepts. Small renewable energy projects or environmentally related segments of medium-sized energy projects have a good chance of approval.

\section{Contact:}

Mr. Fred Zobrist, Director

Office of Capital Projects and Engineering

USAID PRE/CAP

Room 550, SA-2

Washington, DC 20523-0223

Tel: (202) 663-2189
PSIP:

Director, Office of Investment

Bureau for Private Enterprise

Room 301, SA-2

515 22nd St., NW

Washington, DC 20523-0231

Tel: (202) 663-2288

\section{USAID Private Sector Energy Development Program (PSED)}

PSED assists the private sector in developing solutions to the energy/power shortage problems in USAIDassisted countries. It operates in the following areas: policy reform and institutional development, private power/energy project development assistance, and program coordination. Funds can be made available for up to 50 percent of the cost of pre-feasibility studies, feasibility studies, or other project development activities, and PSED's participation is limited to approximately $\$ 200,000$ per project. 
Contact:

Mr. Mark I. Croke, Deputy Director

Private Sector Energy Development Program

1601 North Kent St.

Suite 1102

Arlington, VA 22209

Tel: (703) 524-4400

\section{USAID Private Biomass Energy Systems and Technology (BEST) Project}

This project is part of Winrock's REPS Fund. It is designed to identify and reduce the technical, commercial, and institutional risks associated with implementing modern biomass energy projects in developing countries. The major emphasis is on supporting site-specific projects in partnership with U.S. and host country private companies. BEST activities fall under two areas: project development and implementation, and technology adaptation and transfer. To qualify, the project must be a privately owned or operated biomass energy project in a USAID-assisted country, initiated by either a U.S. company or host country company, and the proposers must demonstrate a financial capability to carry project forward.

\section{Contact:}

Renewable Energy and Environment Program

Winrock International

1611 North Kent St.

Suite 600

Arlington, VA 22209

Tel: (703) 525-9430

\section{U.S. Export Council for Renewable Energy (US/ECRE)}

The U.S. Export Council for Renewable Energy and its member trade organizations provide information on renewable energy and energy efficiency technologies through reports, brochures, conferences, workshops, trade missions, and participation in global databases. The US/ECRE group serves as a point of contact and facilitator between potential foreign buyers and U.S. private companies. It facilitates projects by: expanding awareness of the renewable energy technologies; identifying project opportunities; matching buyer needs with U.S. suppliers; helping to access sources of finance, funding or technical assistance from U.S. government, multilateral and private sources; and building private and public sector infrastructure in foreign markets.

\section{Contact:}

U.S. Export Council for Renewable Energy (US/ECRE)

122 C St., NW

Fourth Floor

Washington, DC 20001

Tel: (202) 383-2550

\section{U.S. Trade and Development Agency (TDA)}

The TDA helps U.S. renewable energy firms in the initial stages of development proposals by providing grants for feasibility studies, orientation visits, and conferences that present U.S. technology and equipment capabilities. TDA supports feasibility studies in developing countries which present significant trade opportunities for U.S. suppliers, and which also enable the host government to determine the 
technical and economic viability of a project with the application of U.S. technology. Any U.S. company can submit a feasibility study proposal to the TDA and they will be evaluated on the basis of host government approval and priority of the project, and an evaluation of technical and financial factors. There is no application for TDA funding; international bidding announcements are listed in the Commerce Business Daily.

\section{Contact:}

U.S. Trade and Development Agency

1621 North Kent St.

Suite 309

Arlington, VA 22209

Tel: (703) 875-4357

\subsection{Project Financing}

Obtaining financing is one of the most challenging aspects of international project development. Government financing is usually offered on a limited or non-recourse basis and can take the form of loans, guarantees, equity, and grants. This section lists the various public sector sources for financing international renewable energy projects.

\section{$\underline{\text { Asian Development Bank }}$}

ADB has funded numerous technical assistance projects in the Asian region, generally for industrial development or major infrastructure planning in its member countries. Its lending has historically been at the government level, but there may be a greater focus on private power. ADB's experience with private sector projects has been limited to small projects with indigenous entrepreneurs, but recent reorganization allows substantial resources to be committed to major capital projects, particularly those using the BOT format. Technical assistance includes feasibility studies for specific projects in an overall development plan. Interested firms must submit bids for evaluation under an international competitive award process. ADB maintains field offices in Bangladesh, India, Indonesia, Nepal, and the South Pacific.

\section{Contact:}

Asian Development Bank

6ADB Avenue, Mandaluyong City

0401 Metro Manila, Philippines

Tel: (63-2) 632-4444

\section{Draper International India Fund}

This is a $\$ 40$ million venture capital fund with a dual presence in India and the U.S. It was set up to provide Indian entrepreneurs with capital and access to U.S. technology and management and it makes equity and equity-related investments in early stage opportunities. The fund also invests in later stage companies that are likely to become public companies in a few years.

\section{Contact:}

Draper International India Fund

50 Fremont St.

Suite 3500

San Francisco, CA 94105

Tel: (415) 284-8696
Washington, DC office:

1730 Pennsylvania Ave., NW, Suite 975

Washington, DC 20006

Tel: (202) 347-0878 


\section{Environment Enterprises Assistance Fund}

This fund provides equity or debt investment capital and business advisory services for renewable energy, and energy efficiency technologies in developing countries. Its aim is to use funds to catalyze projects in order to overcome non-market barriers encountered by small-scale renewable energy and environmentally responsible technologies. Through its presence in developing countries, its main goal is to cultivate the skills of "environmental entrepreneurs." The Fund operates in Southeast Asia and in Central America and offers financial packages ranging from $\$ 150,000$ to $\$ 5$ million.

\section{Contact:}

Environment Enterprises Assistance Fund

1901 North Moore St.

Suite 1004

Arlington, VA 22209

Tel: (703) 522-5928

\section{Export-Import Bank of the U.S. (ExIm Bank)}

The ExIm Bank is an independent U.S. government agency that helps finance exports of U.S. goods and services. It supplements and encourages commercial financing. By neutralizing the effect of exports credit subsidies from other governments and by absorbing risks that the private sector will not accept, ExIm Bank enables U.S. exporters to compete internationally on the basis of product quality, service, and price.

Through loan guarantees and insurance, the agency makes working capital available to U.S. exporters and through direct loans and grants, it provides credit at attractive interest rates to foreign buyers to encourage their purchase of U.S. goods and services. With project financing, ExIm provides loans or guarantees for new projects (not expansions) and relies on the project's cash flow for repayment. Such limited recourse transactions should involve at least $\$ 25$ million of U.S. content.

\section{Contact:}

Export-Import Bank of the U.S.

International Business Development Group

811 Vermont Ave., NW

Washington, DC 20571

Tel: (202) 565-3900

\section{. ExIm Bank/Japan ExIm Bank Cofinancing Arrangement}

In this arrangement, the U.S. ExIm Bank and Japan ExIm jointly support financing offers for major capital projects in Asia where there is a consortium involving both Japanese and U.S. firms. The aim is to permit cofinancing of major capital projects without drawing either government's financing institutions into a cost-of-capital competition.

\section{Contact:}

Mr. Terrence Hulihan, Vice President-Asia Export-Import Bank of the U.S.

811 Vermont Ave., NW

Washington, DC 20571

Tel: (202) 566-8885 


\section{Global Environment Emerging Markets Fund}

This fund provides investments in environment-oriented industries, especially those engaged in developing, financing, operating, or supplying infrastructure projects related to delivering clean energy and potable water.

\section{Contact:}

Global Environment Management Corporation

1201 New York Ave., NW

Suite 220

Washington, DC 20005

Tel: (202) 789-4500

\section{Global Environment Facility (GEF)}

The GEF provides grants for investment projects, technical assistance, and research that focus on the global environment. It is funded by the World Bank and the United Nations, and differs from the World Bank in two ways: it finances projects specifically targeted at global (not national or local) environmental problems and it loans money at low interest rates to middle-income countries with significant environmental problems. It funds projects in the following areas: global warming, biodiversity, international waters, and ozone depletion. GEF-sponsored projects must also contribute to development, knowledge creation, and dissemination.

\section{Contact:}

GEF Administrator

The World Bank

1818 H St., NW

Washington, DC 20433

Tel: (202) 473-1053

Inter-American Development Bank (IDB)

IDB is the principal source for external finance for most Latin American countries. It funds technical assistance projects primarily for industrial development or major infrastructure planning. IDB field offices may assist U.S. companies with business advisory services and renewable energy project identification. Interested firms must submit bids for evaluation under an international competitive award process.

\section{Contact:}

Inter-American Development Bank Headquarters

IDB Energy Division

1300 New York Ave., NW

Washington, DC 20577

Tel: (202) 623-1969

Tel: (202) 623-1000

IDB Environment Division

Tel: (202) 623-1864

\section{International Finance Corporation (IFC)}

IFC is the private arm of the World Bank Group and it invests through loans or equity directly in private ventures without government guarantees. It also provides advisory services and mobilizes additional financial resources through its support of capital market formation, technical assistance, technical and market assessments and privatization efforts. IFC will share up to 25 percent of project costs in project 
financing and it lends at market rates. The average loan amount is $\$ 10$ million and maturities range from 8-12 years.

\section{Contact:}

Mr. Vijay Chaudry, Divisional Manager

Dept. of Investments

Infrastructure Power Division

International Finance Corporation

1850 I St., NW

Washington, DC 20433

Tel: (202) 473-0575

\section{Overseas Private Investment Corporation (OPIC)}

OPIC is a U.S. government agency that encourages mutually beneficial U.S. private business investment in developing countries. It offers loans and loan guarantees in the form of project financing with a maximum amount of $\$ 200$ million. OPIC also offers lease financing, insurance, advisory services, investment missions, and outreach to assist U.S. investors. It has sponsored two special interest funds for investment, the Environment Fund which includes clean energy projects, and the Asia Fund which focuses on investment projects by U.S. firms in Asia. The target level of funding for these special funds is $\$ 75-100$ million. Currently, OPIC does not operate in China.

\section{Contact:}

Overseas Private Investment Corporation

Special Funds:

1100 New York Ave., NW

Mr. Graham Williams

Washington, DC 20527

Tel: (202) 336-8479

Tel: (202) 336-8663

\section{Private Export Funding Corporation (PEFCO)}

PEFCO is a private corporation owned by a group of 51 banks and 7 industrial corporations. It makes loans to foreign buyers of U.S. goods and services who wish to obtain financing on terms that include U.S. dollars, fixed rates and long repayment maturities, and cannot obtain them from traditional sources. Loans are for up to 15 years and PEFCO charges a market interest rate. Loans range from \$20-150 million.

Contact:

Mr. Richard Youtz

Private Export Funding Corporation

280 Park Ave.

Suite 4W

New York, NY 10217

Tel: (212) 557-3100

\section{Small Business Administration Export Finance}

This program guarantees up to $\$ 750,000$ for either short- or long-term loans to help small business develop export markets. Loan proceeds may be used for working capital or fixed assets but may not be used to establish operations overseas. A borrower must meet SBA's "small business" definition. 
Contact:

U.S. Small Business Administration

409 Third St., NW

Washington, DC 20416

Tel: (202) 205-6720 (Office of International Trade) or

Tel: (202) 205-6570 (Office of Financial Assistance)

OR contact local SBA office

The World Bank

The World Bank extends more than $\$ 20$ billion a year in loans and credits to governments in developing countries, with a portion of this resulting in contracting opportunities for U.S. suppliers of goods and services. Investment loans are the most common type of lending and they finance individual projects and segments of a country's investment program in a specific sector. Loans are made to or guaranteed by the borrowing government and are based on economic considerations alone.

Contact:

The World Bank

Renewable Energy Contact: Infrastructure, Energy \& Environment Division

1818 H St., NW

Washington, DC 20433

Tel: (202) 473-2469

\section{Utech Climate Challenge Fund (UCC)}

The UCC manages $\$ 95$ million in venture capital funds. Its focus is investing in ventures which develop or commercialize electrotechnologies and renewable energy technologies. As of 1995, the Utech portfolio included 35 active companies world-wide.

\section{Contact:}

Arete Ventures, Inc.

6110 Executive Blvd.

Suite 1040

Rockville, MD 20852

Tel: (301) 881-2555

\subsection{Insurance}

International business involves a certain amount of risk. The insurance programs listed in this section are designed to protect renewable energy firms against the political and commercial risk of doing business overseas.

\section{Export-Import Bank of the U.S. (ExIm Bank)}

ExIm Bank has a specific trade insurance designed to protect the U.S. seller of goods from default by the purchaser. Its policies cover political and commercial risks of non-payment on short-term (up to 180 days) and medium-term (181 days - 5 years) export receivables. More than 90 percent of the export credit insurance provided to date has been for short-term insurance. Its policies include: new-to-export policy; umbrella policy; short-term, single buyer policy; short-term, multi-buyer policy; medium-term policy; and floor-plan coverage (combination short- and medium-term). 


\section{Contact:}

Export-Import Bank of the U.S.

Export Credit Insurance

811 Vermont Ave., NW

Washington, DC 20571

Tel: (202) 565-3630

\section{Multilateral Investment Guarantee Agency (MIGA)}

MIGA was formed by the World Bank to facilitate investment in developing member countries and complement efforts of other insurance programs. It offers long-term political risk insurance and provides advisory and consultative services. The MIGA guarantee is typically available for a 15-year term which can be extended to 20 years in some cases; coverage is limited to new investments between member countries where the investment project in located in a developing country. MIGA has more than 132 member countries.

\section{Contact:}

Chief Guarantee Officer, Guarantees Dept.

Multilateral Investment Guarantee Agency

1800 G St., NW

12th Floor

Washington, DC 20433

Tel: (202) 473-6163

\section{Overseas Private Investment Corporation (OPIC)}

OPIC offers political risk insurance to U.S. investors, contractors, exporters, and financial institutions involved in international business. Its basic insurance program covers currency inconvertibility, expropriation, or political violence. OPIC also offers special insurance programs for oil and gas exploration and production, mineral development, construction and other contracting projects, cross-border lease transactions, and institutional loans. Insurance covers up to 90 percent of the investment and can be for as long as 20 years. No single project can exceed $\$ 100$ million in total coverage. Currently, OPIC does not operate in China.

\section{Contact:}

Overseas Private Investment Corporation

Regional Manager, Insurance Dept.

1100 New York Ave., NW

Washington, DC 20527

Tel: (202) 336-8799

\subsection{Private Financing Sources}

The chapter concludes with a brief list of private companies that have shown interest in funding international power projects. ${ }^{144}$ Because of the high risk associated with both renewable technologies and developing countries, private companies look at projects on a case-by-case basis. This is not an exhaustive

${ }^{144}$ Burr, Michael T., 1997, “Refocusing Finance," Independent Energy, March, p. 16. 
list by any means, so the developer would be advised to contact an investment adviser or insurance broker for further advice and direction.

- $\quad$ ABN Amro

- AIG

- Banque Paribas

- BZW

- Credit Suisse/First Boston

- Dresdner Kleinwort Benson

- Industrial Bank of Japan

- JP Morgan

- Lehman Brothers

- Lloyd's of London

- Morgan Stanley

- PaineWebber

- TCW

- Union Bank of Switzerland 


\subsection{CONCLUSION}

The international power market has provided a multitude of opportunities for private developers. Due to their projected growth in power demand and their large agrarian economies, India and China were the primary focus of this international biopower market analysis. This report assesses the financial and policy environments pertaining to international biopower development because they have been the main hurdles to project success. It points out that none of these projects will succeed unless the country government is committed to supporting open market policies, providing institutional support through their legal system, regulatory structure and enforcement mechanisms, and offering a secure and healthy business environment.

In India, the government has actively supported and promoted renewable energy, including biopower, and it offers financial incentives to private companies interested in developing renewable power projects. India, however, has a financially troubled power generation sector and a subsidy structure that limits the State Electricity Boards' ability to escape the cycle. China recognizes the need for renewable energy in its power generation mix, but the government has not tangibly supported its development. In addition, because it is fluctuating between being a socialist nation and opening its markets, its financial incentives for foreign participation in the power sector are not yet mature. In particular, it offers no incentives targeting renewable power development. Nevertheless, these two countries, because of the sheer magnitude of their future electricity demand, their large potential for biomass resources, their large agrarian economies, and the environmental concerns associated with their rapid development, are the top targets for international biopower development.

We conclude that international biopower applications are best suited for certain niche applications. Because it is supported by the government, cogeneration in the sugar industry is the most viable option in both India and China. Despite the hurdles they face in the U.S., waste-to-energy projects are another strong possibility: Repowering old coal plants and co-firing biomass with coal show the potential to improve efficiency and reduce environmental emissions. Rural electrification is a necessity in both countries but China is a better market for this effort from a developer's point of view. India's longstanding agricultural power subsidy structure would prevent developers from realizing a return adequate to cover the cost of production, if efforts are aimed at the agricultural consumer. Small-scale industrial and commercial establishments are better markets for rural applications of biopower in India.

Brazil, Indonesia, and the Philippines are also good targets for these applications, albeit to a smaller scale. Each of these countries has good biomass resource potential and a growing demand for electricity. Bioenergy benefits from an historical presence in Brazil and cogeneration at sugar mills is of interest to the government. In Indonesia and the Philippines, rural electrification is a priority and both countries have excellent business climates for foreign investment.

Regardless of the target market, international private power development is only viable when the host country government provides transparent, reliable, and enforceable policy and investment climates. The risk associated with doing business in any developing country makes such an environment paramount. The countries discussed in this report have a great deal of potential for private power development overall, as evidenced by the foreign business activity already underway within their borders. However, biopower development is a unique market niche saddled with additional economic, environmental, and social responsibilities which vary from country to country. As such, the private power developer will be best served if each project is approached with an eye for the comprehensive nature of its impact. 


\section{REFERENCES}

Volume II

American Embassy-Economic Section, Jakarta, 1992, Indonesia's Electric Power Sector, January.

Antares Group, Inc., 1996, Comparison of Large Central and Small Decentralized Power Generation in India, prepared for the U.S. Department of Energy/National Renewable Energy Laboratory, Landover, MD, December 15.

Antares Group, Inc., 1996, Repowering Applications and Markets for Biomass Fuel Integration and Augmentation, prepared for the U.S. Department of Energy/National Renewable Energy Laboratory, Landover, MD, July 22.

"Back to Budgets," 1997, The Economist--A Survey of India, February 22.

Bond, Gary and Laurence Carter, 1995, "Financing Energy Projects: Experience of the International Finance Corporation," Energy Policy, vol.23, no.11, pp. 967-975.

Braatz, Barbara V., Bubu P. Jallow, Sandor Molnar, Daniel Murdiyarso, Martha Perdomo, and John F. Fitzgerald, eds., 1996, Greenhouse Gas Emission Inventories: Interim Results from the U.S. Country Studies Program, Kluwer Academic Publishers: Dordrecht, the Netherlands.

Bond, Gary and Laurence Carter, 1995, "Financing Energy Projects: Experience of the International Finance Corporation," Energy Policy, vol. 23, no. 11, pp. 967-975.

Burr, Michael T., 1997, “Refocusing Finance," Independent Energy, March.

Burr, Michael T., 1993, "Strategies for Success," Independent Energy, April.

Center for Clean Air Policy, 1996, Joint Implementation Projects in Central \& Eastern Europe, Regional Conference of Joint Implementation: Countries in Transition, Conference Proceedings, Prague, Czech Republic, April 17-19.

“China: A Matter of Priorities," 1995, Far Eastern Economic Review, November 16, p. 71.

“China: New Deals Put Power Stations Back on Line," 1997, The Economist Intelligence Unit.

“China: Uncertain Future for FDI," 1997, The Economist Intelligence Unit.

“City Life,” 1997, The Economist--A Survey of China, March 8.

Cox, Kathleen, 1996, “A Prayer to Ganesha," World Business, July/August, pp. 30-35.

Delphos, William A., 1996, Power Money: The International Business Executive's Guide to Government Resources, Renewable Energy Edition, sponsored by the US Export Council for Renewable Energy and U.S. Agency for International Development (USAID).

DRI/McGraw Hill, 1996, The Future of the Electric Power Industry. 
Dunkerley, Joy, 1995, "Financing the Energy Sector in Developing Countries: Context and Overview," Energy Policy, vol.23, no.11, pp. 929-939.

GAO Testimony, 1996, International Trade: Challenges and Opportunities for U.S. Businesses in China, Washington, DC, July 29.

Ganguli, Bodhisatva, 1995, “India's Private Power Plan,” Independent Energy, January.

Government of India (GOI), Eighth Five Year Plan, New Delhi, India.

Government of India Press Information Bureau.

Government of India Planning Commission, 1995, Working of State Electricity Boards and Electricity Departments, New Delhi, India.

Guruswamy, Krishnan, The Associated Press, 1997, "India's Government Must Resign," April 11.

Harris, John F., 1997, “Gore Fumbles in Juggling 2 Messages," The Washington Post, March 27, p. A1.

Himberg, Harvey, 1995, "The View from the Overseas Private Investment Corporation (OPIC): Support to Power Projects in Asia," Energy Policy, vol.23, no.11, pp. 977-980.

"In Search of Satisfaction," 1997, The Economist-A Survey of China, March 8.

“India Unleashes Securities Mart," 1997, The Wall Street Journal, January 31, p. A14.

International Energy Agency (IEA), 1996, World Energy Outlook, 1996 Edition, OECD: Paris, France.

Ishiguro, M. and T. Akiyama, 1995, Energy Demand in Five Major Asian Developing Countries, World Bank Discussion Paper \#277.

Jakeway, Lee, Winrock International, 1996, personal communication, January 30.

Jechoutek, Karl G. and Ranjit Lamech, 1995, “New Directions in Electric Power Financing,” Energy Policy, vol.23, no.11, pp. 941-953.

Karp, Jonathan, 1997, "Frustrated U.S. Investors are Turning Cold in India," The Wall Street Journal, February 19, p. A12.

McGraw Hill, 1997, International Private Power Quarterly, First Quarter.

McGraw Hill, 1996, International Private Power Quarterly, Fourth Quarter.

"Men from the Ministry," 1997, The Economist--A Survey of India, February 22.

Miller Freeman Publications, 1995, Pulp \& Paper International's International Fact and Price Book, California.

National BioEnergy Industries Association (NBIA), 1995, Bagasse-Based Cogeneration in India: A Market Primer for U.S. Companies, Washington, DC, March. 
Office of Technology Assessment, 1992, Fueling Development: Energy Technologies for Developing Countries, OTA-E-516, Washington, DC.

"Opening the Market for Cogenerated Power in Tamil Nadu and Karnataka," 1997, Winrock International REEP Update.

Perlack, Robert D., Oak Ridge National Laboratory, 1993, "Biomass Energy Development in Developing Countries," (presentation), October.

Poirier, Jean-Louis, 1996, "Global Power: The Big Picture," in Proceedings from the Power-Gen '96 International Conference and Exhibition, Florida, December 4-6.

Power Tech Associates, P.C., 1992, Definitional Mission to India Regarding Private Power Projects, Findings and Recommendations, December.

Qoyum, A., 1997, "Forum on World Bank Role in Oil and Gas Sector: Indonesian Gas Development," March.

Sinton, Jonathan E., ed., Lawrence Berkeley Laboratory, China Energy Databook, 1992 Edition, June.

Tata Energy and Resources Institute, 1997, personal communication, April.

Tata Energy Research Institute (TERI), 1996, TERI Energy Data Directory \& Yearbook 1995/96 (TEDDY), New Delhi, India.

"The Death of Gradualism," 1997, The Economist--A Survey of China, March 8.

The Economist Intelligence Unit, 1997.

The Hindu, 1996, September 24.

"The Importance of Foreign Devil Money," 1997, The Economist--A Survey of China, March 8.

Turnbull, Jane, EPRI, 1993, Strategies for Achieving a Sustainable, Clean and Cost-Effective Biomass Resource, January.

USAID, Office of Energy and Infrastructure, 1993, Sources of Finance for Private Power Projects in Asia, Business Focus Series, January.

U.S. Department of Energy, 1994, Foreign Markets for U.S. Clean Coal Technologies, DOE/FE-0317, Washington, DC, May 2.

U.S. Department of Energy/Energy Information Administration (DOE/EIA), 1996, Annual Energy Outlook 1996, DOE/EIA-0383(96), Washington, DC, January.

U.S. Department of Energy/Energy Information Administration (DOE/EIA), 1996, Emissions of Greenhouse Gases in the United States 1995, DOE/EIA-0573(95), Washington, DC, October.

U.S. Department of Energy/Energy Information Administration, 1996, International Energy Outlook 1996, DOE/EIA-0484(96), Washington, DC, May. 
U.S. General Accounting Office (GAO) Testimony, 1996, International Trade: Challenges and Opportunities for U.S. Businesses in China, Washington, DC, July 29.

"Work in Progress," 1997, The Economist--A Survey of India, February 22.

World Bank, 1996, China: Renewable Energy for Electric Power, Washington, DC, September 11.

World Bank, World Data 1995 (CD-ROM).

World Bank, 1994, World Development Report 1994: Infrastructure for Development, Oxford University Press: Washington, DC.

Ye, Liao, 1993, "Environmental Protection: Progress and Challenges," Beijing Review, July 12-18, p. 16. 
Public reporting burden for this collection of information is estimated to average 1 hour per response, including the time for reviewing instructions, searching existing data sources, gathering and maintaining the data needed, and completing and reviewing the collection of information. Send comments regarding this burden estimate or any other aspect of this Davis Highway, Suite 1204, Arlington, VA 22202-4302, and to the Office of Management and Budget, Paperwork Reduction Project (0704-0188), Washington, DC 20503.

\begin{tabular}{|l|l|l|}
\hline 1. AGENCY USE ONLY (Leave blank) & $\begin{array}{c}\text { 2. REPORT DATE } \\
\text { September } 1998\end{array}$ & $\begin{array}{l}\text { 3. REPORT TYPE AND DATES COVERED } \\
\text { NREL Subcontract Report }\end{array}$ \\
\hline
\end{tabular}

\section{TITLE AND SUBTITLE}

International and Domestic Market Opportunities for Biomass Power Vol. I \& II

5. FUNDING NUMBERS

Task \#: T1216027

\section{AUTHOR(S)}

Antares Group, Inc.

\section{PERFORMING ORGANIZATION NAME(S) AND ADDRESS(ES)}

Antares Group, Inc.

4351 Garden City Dr., Ste.301

Landover, MD 20785

\section{SPONSORING/MONITORING AGENCY NAME(S) AND ADDRESS(ES)}

National Renewable Energy Laboratory

1617 Cole Boulevard

Golden, CO 80401-3393

\section{SUPPLEMENTARY NOTES}

\section{2a. DISTRIBUTION/AVAILABILITY STATEMENT}

National Technical Information Service

U.S. Department of Commerce

5285 Port Royal Road

Springfield, VA 22161 12b. DISTRIBUTION CODE

UC-600

13. ABSTRACT (Maximum 200 words) ${ }^{\star \star \star \star \star \star \star \star}$ This report examines the domestic and international markets for biopower. Domestic and foreign markets present fundamentally different challenges to private power developers. Vol. I focuses on the domestic market for biopower. The domestic challenge lies in finding economically viable opportunities for biopower. Vol. I outlines the current state of the $U>S>$ biomass industry, discusses policies affecting biomass development, describes some demonstration projects currently underway, and discusses the future direction of the industry. Vol. II focuses on the international market for biopower. Recent literature states that the electricity investment and policy climate in foreign markets are the key elements in successful private project development. Vol. II discusses the financing issues, policy climate, and business incentives and barriers to biopower development. As India and China are the largest future markets for power, they are the focus of this volume. Three other top markets-Brazil, Indonesia, and the Philippines are also discussed. Potential financial resources wrap up the discussion.

14. SUBJECT TERMS ***

17. SECURITY CLASSIFICATION OF REPORT
18. SECURITY CLASSIFICATION OF THIS PAGE
19. SECURITY CLASSIFICATION OF ABSTRACT
15. NUMBER OF PAGES 162

16. PRICE CODE

20. LIMITATION OF ABSTRACT

NSN 7540-01-280-5500

Standard Form 298 (Rev. 2-8 Prescribed by ANSI Std. Z39- 